NATIONAL LABORATORY MANAGED BY UT-BATTELLE

FOR THE DEPARTMENT OF ENERGY

\section{LTA Physics Design: \\ Description of All MOX Pin LTA Design}

Project Manager

A. M. Pavlovichev

S. Alioshin

S. Bolshagin

A. Kalashnikov

E. Kapranova

V. Korobitsyn

Y. Styrine

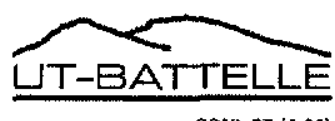

A Russian Contribution to the Fissile Materials Disposition Program 


\section{DOCUMENT AVAILABILITY}

Reports produced after January 1, 1996, are generally available free via the U.S. Department of Energy (DOE) Information Bridge:

Web site: http://www.osti.gov/bridge

Reports produced before January 1, 1996, may be purchased by members of the public from the following source:

National Technical Information Service

5285 Port Royal Road

Springfield, VA 22161

Telephone: 703-605-6000 (1-800-553-6847)

TDD: 703-487-4639

Fax: 703-605-6900

E-mail: info@ntis.fedworld.gov

Web site: http://www.ntis.gov/support/ordernowabout.htm

Reports are available to DOE employees, DOE contractors, Energy Technology Data Exchange (ETDE) representatives, and International Nuclear Information System (INIS) representatives from the following source:

Office of Scientific and Technical Information

P.O. Box 62

Oak Ridge, TN 37831

Telephone: 865-576-8401

Fax: 865-576-5728

E-mail: reports@adonis.osti.gov

Web site: http://www.osti.gov/contact.html

This report was prepared as an account of work sponsored by an agency of the United States Government. Neither the United States government nor any agency thereof, nor any of their employees, makes any warranty, express or implied, or assumes any legal liability or responsibility for the accuracy, completeness, or usefulness of any information, apparatus, product, or process disclosed, or represents that its use would not infringe privately owned rights. Reference herein to any specific commercial product, process, or service by trade name, trademark, manufacturer, or otherwise, does not necessarily constitute or imply its endorsement, recommendation, or favoring by the United States Government or any agency thereof. The views and opinions of authors expressed herein do not necessarily state or reflect those of the United States Government or any agency thereof. 


\title{
LTA PHYSICS DESIGN: DESCRIPTION OF ALL MOX PIN LTA DESIGN
}

Project Manager:

A. M. Pavlovichev
S. Alioshin
S. Bolshagin
A. Kalashnikov
E. Kapranova
V. Korobitsyn
Y. Styrine

Date Published: September 2001

\author{
Prepared by \\ Russian Research Center "Kurchatov Institute" \\ Institute of Nuclear Reactors \\ under subcontract 85B-99398V
}

Funded by

Office of Fissile Materials Disposition

U. S. Department of Energy

Prepared for

Computational Physics and Engineering Division

OAK RIDGE NATIONAL LABORATORY

Oak Ridge, Tennessee 37831

managed by

UT-BATTELLE, LLC

for the

U. S. DEPARTMENT OF ENERGY

under contract DE-AC05-00OR22725 


\author{
Russian Research Center "Kurchatov Institute" \\ Institute of Nuclear Reactors \\ VVER Division
}

\begin{abstract}
Joint U.S. / Russian Project to Update, Verify and Validate Reactor Design/Safety Computer Codes Associated with Weapons-Grade Plutonium Disposition in WVER Reactors
\end{abstract}

\title{
LTA PHYSICS DESIGN. DESCRIPTION OF ALL MOX PIN LTA DESIGN
}

General Order 85B-99398V

(Report)

Project Manager

A.M.Pavlovichev

Executed by

S.Alioshin

S.Bolshagin

A.Kalashnikov

E. Kapranova

V. Korobitsyn

Y.Styrine 
RUSSIAN RESEARCH CENTER KURCHATOV INSTITUTE

Design Studies of "100\%MOX" Lead Test Assembly (Report for FY99)

\section{ACRONYMS}

\begin{tabular}{|l|l|l|}
\hline Russian & & $\begin{array}{l}\text { American } \\
\text { Equivalent }\end{array}$ \\
\hline AZ & emergency (accident) protection & AP \\
\hline AZ-1 & $\begin{array}{l}\text { state with all the control rods fully inserted except of } \\
\text { one the most effective stuck in upper position }\end{array}$ & AP-1 \\
\hline BOC & Beginning Of fuel Cycle & BOC \\
\hline BPR & Burnable Poison Rod & BPR \\
\hline DNBR & Departure from Nucleate Boiling Ratio & DNBR \\
\hline DTC & Doppler Temperature Coefficient & DTC \\
\hline EFPD & Effective Full Power Day & EFPD \\
\hline EOC & End Of fuel Cycle & EOC \\
\hline FP & Fission Products & FP \\
\hline IPPE & Institute of Physics and Power Engineering (Obninsk) & IPPE \\
\hline KI & Kurchatov Institute & KI \\
\hline LTA & Lead Test Assembly & LTA \\
\hline LWR & Light Water Reactor & LWR \\
\hline MCL & Minimum Controllable reactor power Level & MCL \\
\hline MDC & Moderator Density Coefficient & MDC \\
\hline MOX & Mixed Oxide (uranium-plutonium fuel) & MOX \\
\hline MTC & Moderator Temperature Coefficient & MTC \\
\hline NPP & Nuclear Power Plant & NPP \\
\hline OR & Regulatory Body (Control Rod) & CR \\
\hline PWR & Pressurized-Water Reactor & PWR \\
\hline RCT & Repeat Criticality Temperature & RCT \\
\hline SUZ & Reactor Control and Protection System & RPS \\
\hline TVS, FA & Fuel Assembly & FA \\
\hline UOX & Uranium Oxide Fuel & UOX \\
\hline VVER & Russian water-water reactor & VVER \\
\hline & & \\
\hline & & \\
\hline
\end{tabular}


RUSSLAN RESEARCH CENTER KURCHATOV INSTITUTE Design Studies of "100\%MOX" Lead Test Assembly (Report for FY99)

\section{EXECUTIVE SUMMARY}

In this document issued according to Work Release 02. P. 99-1b the results of neutronics studies of $« 100 \% \mathrm{Pu} »$ MOX LTA design are presented. The parametric studies of infinite MOX-UOX grids, MOX-UOX core fragments and of VVER-1000 core with 3 MOX LTAs are performed. The neutronics parameters of MOX fuelled core have been performed for the chosen design MOX LTA using the Russian 3D code BIPR-7A and 2D code PERMAK-A with the constants prepared by the cell spectrum code TVS-M. 
RUSSIAN RESEARCH CENTER KURCHATOV INSTITUTE

Design Studies of “100\%MOX” Lead Test Assembly (Report for FY99)

\section{CONTENTS}

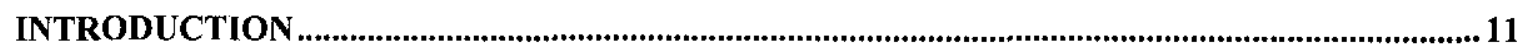

1. DEFINITIONS

2. PARAMETRIC STUDIES OF MOX LTA DESIGN (STAGE “ASSEMBLY”)................................19

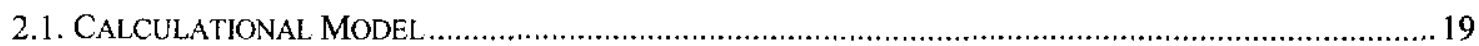

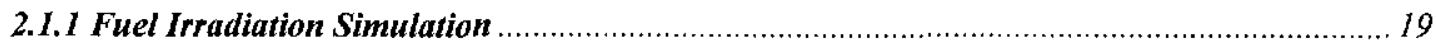

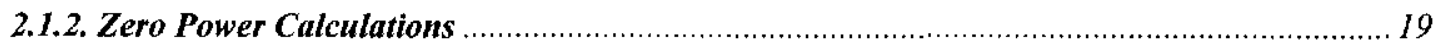

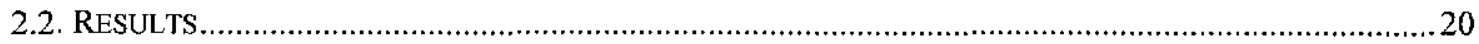

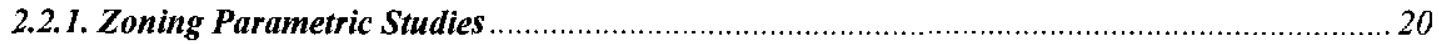

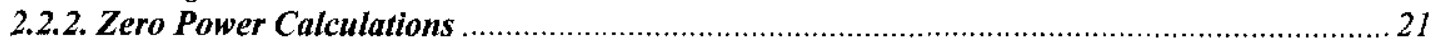

3. PARAMETRIC STUDIES OF MOX LTA DESIGN (STAGE "CORE FRAGMENTS")...............22

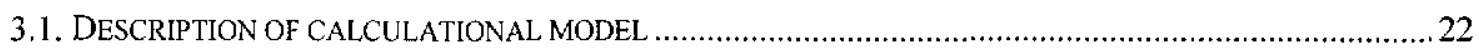

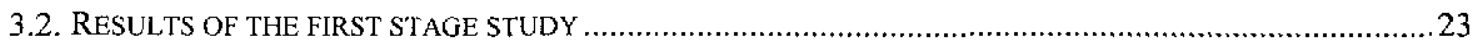

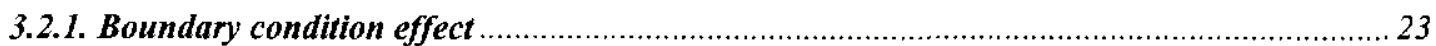

3.2.2. Effect of plutonium content in MOX FAs on power non-uniformity ............................... 23

3.2.3. Effect of plutonium zonning in MOX FAs on power non-uniformity .................................2 24

3.2.4. Refinement of the results with consideration for FA burnup non-uniformity and fuel

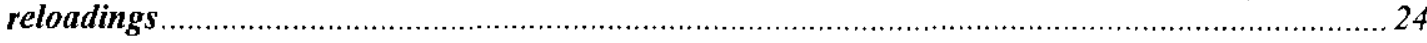

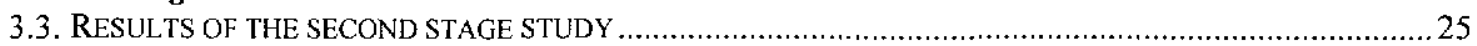

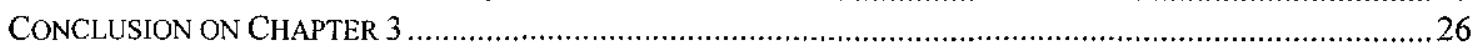

4. CALCULATIONS OF VVER-1000 CORE WITH 3 MOX LTAS (STAGE "CORE") ...................28

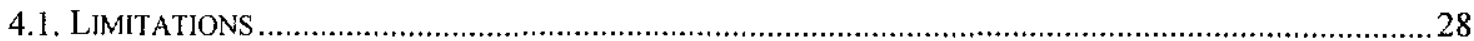

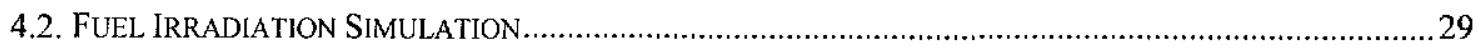

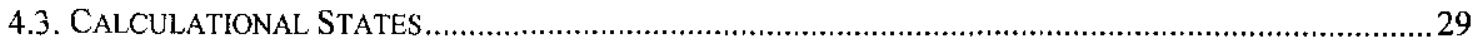

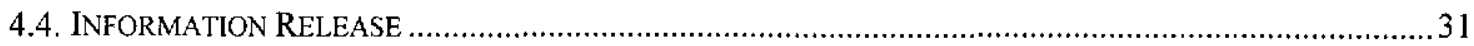

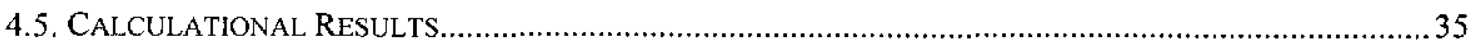

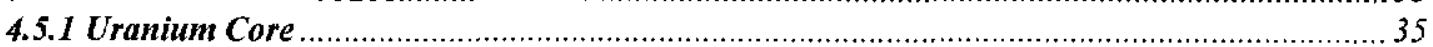

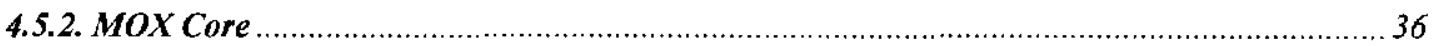

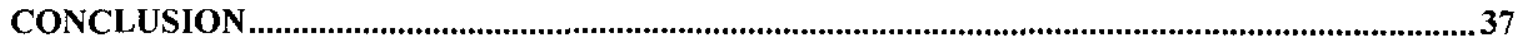

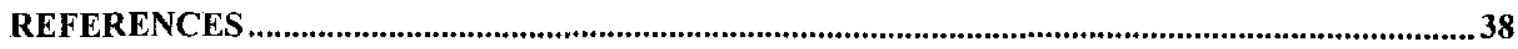

ANNEX

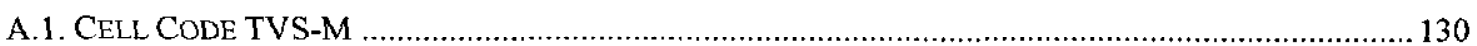

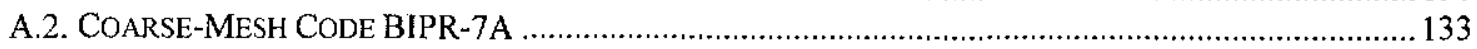

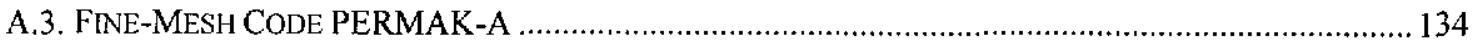

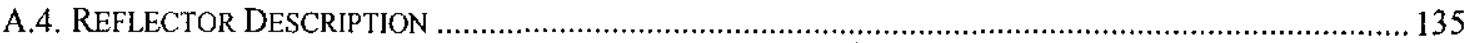

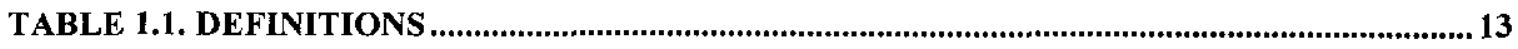

TABLE 2.1. COMPOSITION OF WEAPONS GRADE PLUTONIUM.............................................39

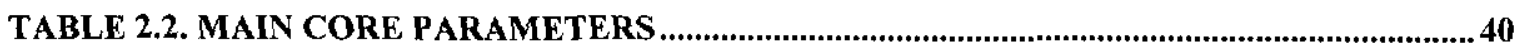


RUSSIAN RESEARCH CENTER KURCHATOV INSTITUTE

Design Studies of "100\%MOX" Lead Test Assembly (Report for FY99)

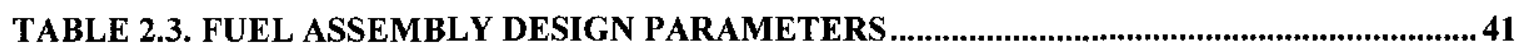

TABLE 2.4. URANIUM FUEL PIN DESIGN PARAMETERS .....................................................42

TABLE 2.5. MOX FUEL PIN DESIGN PARAMETERS ........................................................................... 43

TABLE 2.6. DISCRETE BURNABLE POISON PIN DESIGN PARAMETERS................................44

TABLE 2.6A. CONTROL ROD DESIGN PARAMETERS........................................................... 45

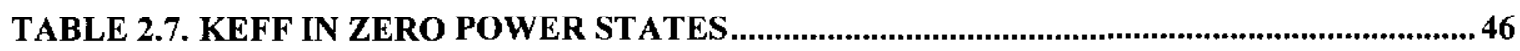

TABLE 2.8. PARAMETERS EVOLUTION IN THE PROCESS OF FUEL IRRADIATION.

REFERENCE URANIUM ASSEMBLAGE. NO BPR ...........................................................................47

TABLE 2.9. PARAMETERS EVOLUTION IN THE PROCESS OF FUEL IRRADIATION.

REFERENCE URANIUM ASSEMBLAGE WITH BORON BPRS ......................................................48

TABLE 2.10. PARAMETERS EVOLUTION IN THE PROCESS OF FUEL IRRADIATION. MOX

LTA 4.4/3.0/2.4

TABLE 2.11. PARAMETERS EVOLUTION IN THE PROCESS OF FUEL IRRADIATION. MOX

LTA 4.4/3.0/2.0

TABLE 2.12. PARAMETERS EVOLUTION IN THE PROCESS OF FUEL IRRADIATION. MOX

LTA 4.4/3.2/2.0

TABLE 2.13. PARAMETERS EVOLUTION IN THE PROCESS OF FUEL IRRADIATION. MOX

LTA 4.2/3.0/2.0

TABLE 3.1. POWER PEAKING FACTORS FOR VARIOUS FA ARRANGEMENTS DEPENDING

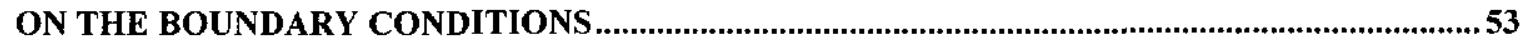

TABLE 3.2. POWER PEAKING FACTORS IN SYSTEM WITH NON-ZONNED MOX FA AT

$x_{P u^{f}}=\mathbf{3 . 7} \%$ .54

TABLE 3.3. POWER PEAKING FACTORS IN SYSTEM WITH ZONNED MOX FA AT

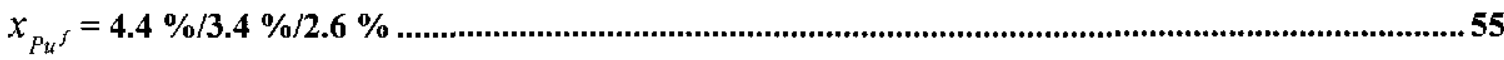

TABLE 3.4. POWER PEAKING FACTORS IN SYSTEM WITH ZONNED MOX FA AT

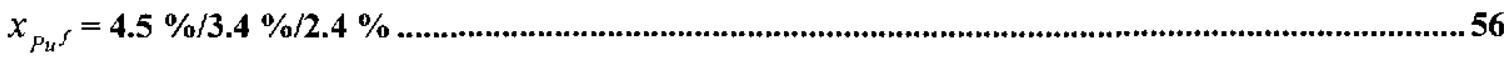

TABLE 3.5. POWER PEAKING FACTORS IN SYSTEM WITH ZONNED MOX FA AT

$x_{P^{f}}=4.6 \% / 3.4 \% / 2.2 \%$

TABLE 3.6. POWER PEAKING FACTORS IN SYSTEM WITH ZONNED MOX FA AT $x_{p_{u} f}=4.7$ $\% / 3.4 \% / 2.0 \%$ .58

TABLE 3.7. FUEL RELOADING SCHEMES 59 
RUSSIAN RESEARCH CENTER KURCHATOV INSTITUTE

Design Studies of " $100 \%$ MOX" Lead Test Assembly (Report for FY99)

TABLE 3.8. EFFECT OF FUEL RELOADING SCHEME ON THE $K_{K}$-CS VALUE. CYCLE № 5. $x_{P_{u} f}=4.6 \% / 3.4 \% / 2.2 \%$

TABLE 4.1. LIMITING PARAMETERS FOR VVER-1000. 61

TABLE 4.2. LIMITS RECOMMENDED FOR TOTAL POWER PEAKING FACTOR KO-TOTAL FOR VVER-1000. 61

TABLE 4.3. RECOMMENDED LIMITING PARAMETERS FOR VVER-1000 WITH 3 MOX LTAS.

TABLE 4.4. LIMITS RECOMMENDED FOR TOTAL POWER PEAKING FACTOR $\mathrm{K}_{\text {O-TOTAL IN }}$ MOX ASSEMBLIES FOR VVER-1000 WITH 3 MOX LTAS

TABLE 4.5. EVOLUTION OF MAIN NEUTRONICS PARAMETERS IN URANIUM REFERENCE CORE . EQUILIBRIUM CYCLE 63

TABLE 4.6. MAIN NEUTRONICS PARAMETERS IN ZERO POWER STATES. REFERENCE URANIUM CORE EQUILIBRIUM CYCLE.

TABLE 4.7. EVOLUTION OF MAIN NEUTRONICS PARAMETERS. FIRST CYCLE WITH 3 MOX LTAS OF "100\%PU" TYPE

TABLE 4.8. MAIN NEUTRONICS PARAMETERS IN ZERO POWER STATES. FIRST CYCLE WITH 3 MOX LTAS OF "100\%PU" TYPE

TABLE 4.9. EVOLUTION OF MAIN NEUTRONICS PARAMETERS. SECOND CYCLE WITH 3

MOX LTAS OF " $100 \%$ PU" TYPE

TABLE 4.10. MAIN NEUTRONICS PARAMETERS IN ZERO POWER STATES. SECOND

CYCLE WITH 3 MOX LTAS OF " $100 \%$ PU" TYPE 68

TABLE 4.11. EVOLUTION OF MAIN NEUTRONICS PARAMETERS. 3-D CYCLE WITH 3 MOX LTAS OF "100\%PU" TYPE. .69

TABLE 4.12. MAIN NEUTRONICS PARAMETERS IN ZERO POWER STATES. THIRD CYCLE WITH 3 MOX LTAS OF "100\%PU" TYPE .70

TABLE 4.13. PIN POWER PEAKING FACTORS ATTAINED DURING FUEL CYCLE. .71

TABLE 4.14. CORE SUBCRITICALITY (SCRAM MARGIN) IN DIFFERENT STATES IN THE PROCESS OF SCRAM ACTUATION. 72

TABLE 4.15A. CONTROL RODS WORTH CALCULATION. STATES DESCRIPTION .73

TABLE 4.15B. CONTROL RODS WORTH IN URANIUM REFERENCE CORE AND IN 3 MOX LTAS LOADED CORES (PCM). .73

TABLE 4.16. CORE REACTIVITY IN THE PROCESS OF CONTROL RODS MOVEMENT....... 74 TABLE 4.17. RETURN CRITICALITY TEMPERATURE. .75 
RUSSIAN RESEARCH CENTER KURCHATOV INSTITUTE

Design Studies of “100\%MOX” Lead Test Assembly (Report for FY99)

FIGURE 2.1. SIMPLIFIED DESIGN FOR URANIUM REFERENCE ASSEMBLY (TYPE A) .......... 76

FIGURE 2.2. CALCULATIONAL MODEL FOR REFERENCE URANIUM ASSEMBLY

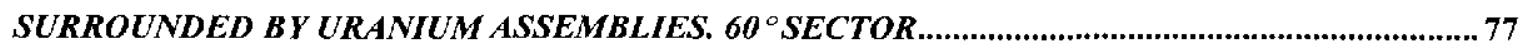

FIGURE 2.3. SIMPLIFIED DESIGN FOR URANIUM ASSEMBLY (TYPES B AND BA) ..................78

FIGURE 2.4. SIMPLIFIED DESIGN FOR URANIUM ASSEMBLY (TYPE C) .................................79

FIGURE 2.5. SIMPLIFIED DESIGN FOR $100 \%$ PLUTONIUM (3-ZONES) MOX LTA ................... 80

FIGURE 2.6. CALCULATIONAL MODEL FOR 3-ZONES (100\% PLUTONIUM) MOX LTA

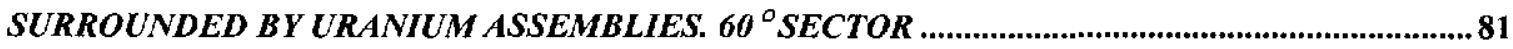

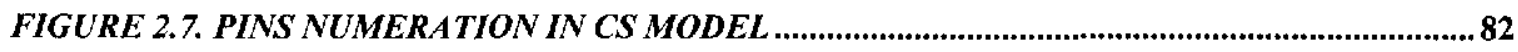

FIGURE 2. 8. EVOLUTION OF KO IN PLUTONIUM-URANIUM SUPER-CELLS ............................ 83

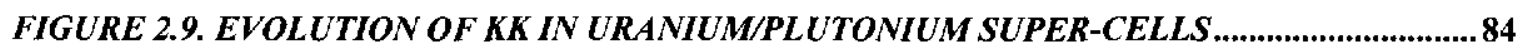

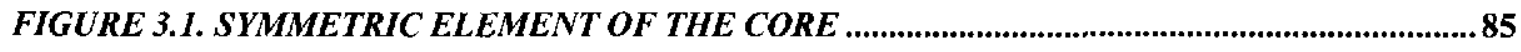

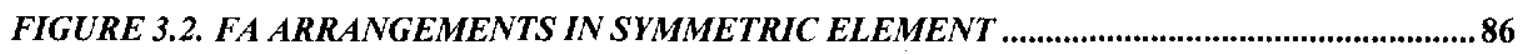

FIGURE 3.3. POWER PEAKING FACTORS $K_{K M A X}-C S(K K-C S)$ AND $K_{K M A X}-C A\left(K_{K}-C A\right)$

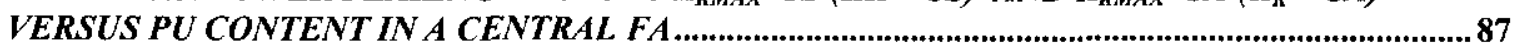

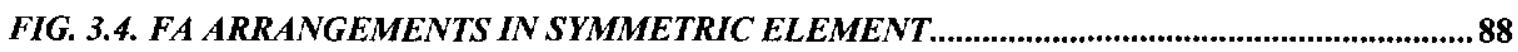

FIG. 3.5. EFFECT OF FUEL RELOADINGS AND BURNUPS ON $K_{K M A X}-$ CS AND $K_{K M A X}-$ CA .

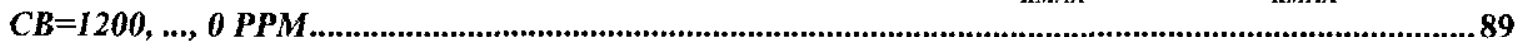

FIG. 3.6. $K_{K M A X}$ - CS AND $K_{K M A X}$ - CA VERSUS FROM PU CONTENT IN A CENTRAL FA ..............91

FIG. 3.7. POWER DISTRIBUTION AT THE BEGINNING OF EQUILIBRIUM CYCLE ....................92

FIG.4.1. ASSEMBLY-BY-ASSEMBLY BURNUP, POWER AND TEMPERATURE DROPS DISTRIBUTIONS. EQUILIBRIUM CYCLE FOR URANIUM REFERENCE CORE WITH BORON BPRS. CORE $60^{\circ} S E C T O R$.

FIG.4.2. ASSEMBLY-BY-ASSEMBLY MAXIMUM LINEAR PIN POWER DISTRIBUTION IN BOC. EQUILIBRIUM CYCLE FOR URANIUM REFERENCE CORE WITH BORON BPRS. CORE $60^{\circ}$ SECTOR

FIG.4.3. ASSEMBLY-BY-ASSEMBLY MAXIMUM LINEAR PIN POWER DISTRIBUTION IN EOC. EQUILIBRIUM CYCLE FOR URANIUM REFERENCE CORE WITH BORON BPRS.CORE $60^{\circ}$ SECTOR 95

FIG.4.4. PIN-BY-PIN POWER DISTRIBUTION IN THE MOST POWERED ASSEMBLY IN BOC. EQUILIBRIUM CYCLE FOR URANIUM REFERENCE CORE WITH BORON BPRS 
RUSSIAN RESEARCH CENTER KURCHATOV INSTITUTE

Design Studies of "100\%MOX" Lead Test Assembly (Report for FY99)

FIG.4.5. PIN-B Y-PIN POWER DISTRIBUTION IN THE MOST POWERED ASSEMBLY IN EOC. EQUILIBRIUM CYCLE FOR URANIUM REFERENCE CORE WITH BORON BPRS

FIG.4.6. CONTROL RODS GROUPING AND POSITIONS OF IN-CORE SELF-POWERED DETECTORS

FIG.4.7. RELOADING SCHEME. FIRST CYCLE WITH 3 MOX LTAS

FIG.4.8. ASSEMBLY-BY-ASSEMBLY POWER DISTRIBUTION. FIRST CYCLE WITH 3 "I00\%PU" MOX LTAS

FIG.4.9. ASSEMBLY-BY-ASSEMBLY BURNUP DISTRIBUTION. FIRST CYCLE WITH 3

"100\%PU" MOX LTAS

FIG.4.10. ASSEMBLY-BY-ASSEMBLY TEMPERATURE DROP DISTRIBUTION. FIRST CYCLE WITH 3 "100\%PU" MOX LTAS.

FIG.4.11. ASSEMBLY-BY-ASSEMBLY MAXIMUM LINEAR POWER DISTRIBUTION IN BOC. FIRST CYCLE WITH 3 "100\%PU" MOX LTAS.

FIG.4.12. ASSEMBLY-BY-ASSEMBLY MAXIMUM LINEAR POWER DISTRIBUTION IN EOC.

FIRST CYCLE WITH 3 "100\%PU" MOX LTAS.

FIG.4.13. PIN-BY-PIN POWER DISTRIBUTION IN THE MOST POWERED ASSEMBLY IN BOC. FIRST CYCLE WITH 3 "100\%PU" MOX LTAS.

FIG.4.14. PIN-B Y-PIN POWER DISTRIBUTION IN THE MOST POWERED ASSEMBLY IN EOC.

FIRST CYCLE WITH 3 "100\%PU" MOX LTAS.

FIG.4.15. PIN-BY-PIN POWER DISTRIBUTION IN MOX LTA IN BOC. FIRST CYCLE WITH 3 "100\%PU" MOX LTAS

FIG.4.16. PIN-BY-PIN POWER DISTRIBUTION IN MOX LTA IN EOC. FIRST CYCLE WITH 3 MOX "100\%PU" MOX LTAS

FIG.4.17. RELOADING SCHEME. SECOND CYCLE WITH 3 MOX LTAS 109

FIG.4.18. ASSEMBLY-BY-ASSEMBLY POWER DISTRIBUTION. SECOND CYCLE WITH 3 MOX "100\%PU" MOX LTAS.

FIG.4.19. ASSEMBLY-BY-ASSEMBLY BURNUP DISTRIBUTION. SECOND CYCLE WITH 3 "100\%PU"MOX LTAS.

FIG.4.20. ASSEMBLY-BY-ASSEMBLY TEMPERATURE DROP DISTRIBUTION. SECOND CYCLE WITH 3 MOX "100\%PU" MOX LTAS.

FIG.4.21. ASSEMBLY-BY-ASSEMBLY MAXIMUM LINEAR PIN POWER DISTRIBUTION IN BOC. SECOND CYCLE WITH 3 "100\%PU" MOX LTAS

FIG.4.22. ASSEMBLY-BY ASSEMBLY MAXIMUM LINEAR PIN POWER DISTRIBUTION IN EOC. SECOND CYCLE WITH 3 "100\%PU" MOX LTAS.

FIG.4.23. PIN-BY-PIN POWER DISTRIBUTION IN THE MOST POWERED ASSEMBLY IN BOC. SECOND CYCLE WITH 3 "100\%PU" MOX LTAS. 
RUSSIAN RESEARCH CENTER KURCHATOV INSTITUTE

Design Studies of "100\%MOX” Lead Test Assembly (Report for FY99)

FIG.4.24. PIN-B Y-PIN POWER DISTRIBUTION IN THE MOST POWERED ASSEMBLY IN EOC.

SECOND CYCLE WITH 3 "100\%PU" MOX LTAS.

FIG.4.25. PIN-BY-PIN POWER DISTRIBUTION IN MOX LTA IN BOC. SECOND CYCLE WITH 3 "100\%PU" MOX LTAS

FIG.4.26. PIN-B Y-PIN POWER DISTRIBUTION IN MOX LTA IN EOC. SECOND CYCLE WITH 3 "100\%PU" MOX LTAS 118

FIG.4.27. RELOADING SCHEME. THIRD CYCLE WITH 3 MOX LTAS. 119

FIG.4.28. ASSEMBLY-BY-ASSEMBLY POWER DISTRIBUTION. THIRD CYCLE WITH 3 "100\%PU" MOX LTAS

FIG.4.29. ASSEMBLY-BY-ASSEMBLY BURNUP DISTRIBUTION. THIRD CYCLE WITH 3 "100\%PU" MOX LTAS

FIG.4.30. ASSEMBLY-BY-ASSEMBLY TEMPERATURE DROP DISTRIBUTION. THIRD CYCLE WITH 3 "100\%PU" MOX LTAS.

FIG.4.31. ASSEMBLY-BY-ASSEMBLY MAXIMUM LINEAR POWER DISTRIBUTION IN BOC. THIRD CYCLE WITH 3 "100\%PU" MOX LTAS

FIG.4.32. ASSEMBLY-BY-ASSEMBLY MAXIMUM LINEAR POWER DISTRIBUTION IN EOC. THIRD CYCLE WITH 3 "100\%PU" MOX LTAS

FIG.4.33. PIN-BY-PIN POWER DISTRIBUTION IN THE MOST POWERED ASSEMBLY IN BOC. THIRD CYCLE WITH 3 MOX LTAS 125

FIG.4.34. PIN-BY-PIN POWER DISTRIBUTION IN THE MOST POWERED ASSEMBLY IN EOC. THIRD CYCLE WITH 3 "100\%PU” MOX LTAS.

FIG.4.35. PIN-BY-PIN POWER DISTRIBUTION IN MOX LTA IN BOC. THIRD CYCLE WITH 3"100\%PU" MOX LTAS.

FIG.4.36. PIN-B Y-PIN POWER DISTRIBUTION IN MOX LTA IN EOC. THIRD CYCLE WITH 3 MOX LTAS OF «ISLAND-2» TYPE ( PU3.8-2.8-U3.7)

FIGURE A. I. EQUILIBRIUM LOADING PATTERN FOR BASE URANIUM CORE WITH BORON BPRS, CORE $60^{\circ}$ SECTOR 136

FIGURE A.2. MODEL OF VVER-1000 REFLECTOR. 137

FIG.A.3. REFLECTOR “ASSEMBLY” OF TYPE I 138 
RUSSIAN RESEARCH CENTER KURCHATOV INSTITUTE Design Studies of "100\%MOX" Lead Test Assembly (Report for FY99)

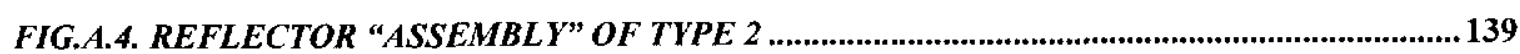

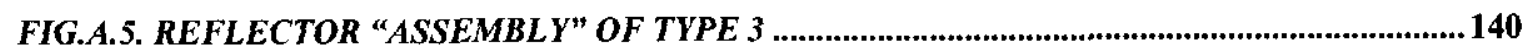

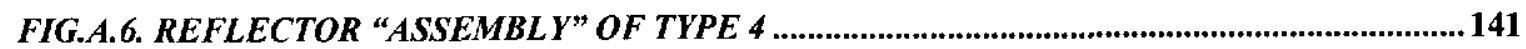

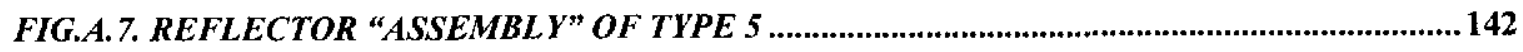




\section{RUSSIAN RESEARCH CENTER KURCHATOV INSTITUTE \\ Design Studies of " $\mathbf{1 0 0 \% M O X " ~ L e a d ~ T e s t ~ A s s e m b l y ~ ( R e p o r t ~ f o r ~ F Y 9 9 ) ~}$}

\section{INTRODUCTION}

This work is a part of Joint U.S. / Russian Project with Weapons-Grade Plutonium Disposition in VVER Reactor and presents the results of studies of full scale MOX LTA named also «100\%Pu» MOX LTA.

It is like to the worldwide type of MOX assembly with 3 types of fissile plutonium enrichment and its simplified design is presented in Fig.2.5.

The presented studies include the following stages:

- “Assembly",

- "Core fragments",

- "Core".

This report completes the studies partially executed in [3] and [6] and can be considered as a one compiled the previous parametric studies of LTAs of « $100 \% \mathrm{Pu} »$ type and VVER-1000 core configurations with 3 MOX LTAs of this type.

At the stage "Assembly" in the process of parametric studies the infinite grid is considered with the following periodical element:

- $\quad$ a central MOX LTA surrounded by typical uranium assemblies.

Parametric studies must be resulted in the following features of MOX LTA design:

- Proximity of power generation in MOX LTA and in some replaced uranium assembly that was used as a base or reference FA (Fig.2.1);

- MOX LTA zoning that ensures an acceptable power peaking factor in calculational system.

The Russian cell code TVS-M [4] is used as a calculational instrument at the stage "Assembly".

At the stage " Core fragments" in the process of parametric studies the infinite grid is considered with the periodical element that simulates a typical core fragment. It is shown in Fig. 2.8.

The object of calculations was to make an estimate of the optimal ratio between fissile nuclides in UOX and MOX FAs and optimal MOX FA zoning.

The codes of IPPE are used in these calculations.

In comparison with [6] the present paper describes the refined variant of this model, which takes into account burnup non-uniformity in various FA regions and FAs reloading simulation. In addition, the version of the TRIANG-PWR code was made to apply periodic boundary conditions instead of reflection conditions used previously. The reflection conditions are incorrect as applied to this model and they being used introduced essential error into power distribution calculations. 


\section{RUSSIAN RESEARCH CENTER KURCHATOV INSTITUTE \\ Design Studies of "100\%MOX" Lead Test Assembly (Report for FY99)}

The stage "Core" comprises studies of characteristics of some base Uranium core (Fig.A.1) with 3 MOX LTAs introduced.

The code TVS-M is used here for generation of neutronics constants to be used in:

- coarse-mesh (assembly-by-assembly) core calculations by the Russian code BIPR7A [7];

- fine-mesh (pin-by-pin) calculations by the Russian code PERMAK-A [7].

The stages "Assembly", "Core fragments" and "Core" are described correspondingly in Chapters 2, 3 and 4 .

In Annex the used codes are briefly described and the detailed reflector description is presented. 


\section{Definitions}

\section{Table 1.1. Definitions}

\begin{tabular}{|c|c|c|c|}
\hline Parameter & Abbreviation & Units & Remarks \\
\hline Calculational system & $\mathrm{CS}$ & & $\begin{array}{c}\text { Infinite grid of multi-assemblies/single } \\
\text { assemblies or core }\end{array}$ \\
\hline CS symmetry sector & Sim & & $\begin{array}{l}30 \text { for } 30^{\circ} \\
60 \text { for } 60^{\circ} \\
120 \text { for } 120^{\circ} \\
360 \text { for full CS. }\end{array}$ \\
\hline Reactivity of CS & $\mathrm{RO}$ & pcm & $\mathrm{RO}=(\mathrm{Keff}-1) / \mathrm{Keff}^{*} 1 . \mathrm{E} 5$ \\
\hline Calculational volume & $\mathrm{Vij}$ & & $\begin{array}{l}\text { Axial fraction } j \text { of assembly number } i \text {. } \\
\text { In VVER- } 1000 \text { calculations, } 10-30 \text { axial } \\
\text { fractions of equal volume are usually used. }\end{array}$ \\
\hline Effective multiplication factor of CS & Keff & & \\
\hline Multiplication factor of CS & Ko & & $\begin{array}{l}\text { Relation of neutron generation to neutron } \\
\text { absorption. } \\
\text { For core calculations Ko values are attributed } \\
\text { to } \mathrm{Vij}\end{array}$ \\
\hline 3-D power distribution in core & $\mathrm{q}_{\mathrm{ij}}$ & & Power in Vij normalized by average Vij power \\
\hline Volume power peaking factor & $\mathrm{Kv}$ & & Maximum in $\mathrm{q}_{\mathrm{ij}}$ values \\
\hline $\begin{array}{l}\text { Radial position of volume power peaking } \\
\text { factor }\end{array}$ & $\mathrm{N}(\mathrm{Kv})$ or $\mathrm{N}_{\mathrm{K}}$ & & $\begin{array}{l}\text { Number of assembly in calculational core } \\
\text { sector where } \mathrm{Kv} \text { is realized }\end{array}$ \\
\hline $\begin{array}{l}\text { Axial position of volume power peaking } \\
\text { factor }\end{array}$ & $\mathrm{M}(\mathrm{Kv})$ or $\mathrm{N}_{\mathrm{Z}}$ & & Number of axial level where $\mathrm{Kv}$ is realized \\
\hline 3-D burnup distribution in core & BUij & $\mathrm{MWd} / \mathrm{kg}$ & Burnup in Vij. \\
\hline
\end{tabular}




\begin{tabular}{|c|c|c|c|}
\hline & & or $\mathrm{GWd} / \mathrm{t}$ & \\
\hline 2-D power distribution in core & $\overline{\mathrm{qi}}$ & & $\begin{array}{l}\text { Assembly powers normalized by average } \\
\text { assembly power in core. }\end{array}$ \\
\hline Radial power peaking factor & $\mathrm{Kq}$ & & Maximum in qi values \\
\hline $\begin{array}{l}\text { Radial position of radial power peaking } \\
\text { factor }\end{array}$ & $\mathrm{N}(\mathrm{Kq})$ or $\mathrm{N}_{\mathrm{K}}$ & & $\begin{array}{l}\text { Number of assembly in calculational core } \\
\text { sector where } \mathrm{Kq} \text { is realized }\end{array}$ \\
\hline Pin linear power & Q1 & $\mathrm{W} / \mathrm{cm}$ & $\begin{array}{l}\text { Pin power for } 1 \mathrm{~cm} \text { of an axial calculational } \\
\text { fraction }\end{array}$ \\
\hline Moment during fuel irradiation & $\mathrm{T}$ & EFPD & \\
\hline 2-D burnup distribution in core & BUi & $\mathrm{MWd} / \mathrm{kg}$ & Average-assembly burnup distribution in core. \\
\hline Average burnup in Uranium assemblies & $\overline{\mathrm{B}}_{U}$ & $\begin{array}{l}\mathrm{MWd} / \mathrm{kg} \\
\text { or } \mathrm{GWd} / \mathrm{t}\end{array}$ & \\
\hline Average burnup in MOX assemblies & $\overline{\mathrm{B}}_{\mathrm{MOX}}$ & $\begin{array}{l}\mathrm{MWd} / \mathrm{kg} \\
\text { or } \mathrm{GWd} / \mathrm{t}\end{array}$ & \\
\hline $\begin{array}{l}\text { Average Boron acid }\left(\mathrm{H}_{3} \mathrm{BO}_{3}\right) \\
\text { concentration }{ }^{\mathrm{a}} \text { in coolant }\end{array}$ & $\begin{array}{c}\mathrm{Cb} \text { or } \\
\mathrm{C}_{\mathrm{H} 3 \mathrm{BO} 3} \\
\end{array}$ & $\begin{array}{l}\text { ppm } \\
\text { or } \mathrm{g} / \mathrm{kg}\end{array}$ & $\begin{array}{l}\mathrm{H}_{3} \mathrm{BO}_{3} \text { fraction in coolant (unit "ppm" means } \\
\text { mg of boron acid in } 1 \mathrm{Kg} \text { of } \mathrm{H}_{2} \mathrm{O} \text { ) }\end{array}$ \\
\hline Critical boron acid concentration in coolant & $\mathrm{Cb}^{\mathrm{crII}}$ & $\begin{array}{l}\text { ppm } \\
\text { or } \mathrm{g} / \mathrm{kg}\end{array}$ & $\mathrm{Cb}\left(\mathrm{C}_{\mathrm{H} 3 \mathrm{BO} 3}\right)$ value ensuring $\mathrm{Keff}=1$ \\
\hline 2-D power distribution in $\mathrm{CS}$ & $\mathrm{q}_{\mathrm{k}}-\mathrm{CS}$ & & $\begin{array}{l}\text { Power of fuel pins normalized by average fuel } \\
\text { pin power in CS. }\end{array}$ \\
\hline $\begin{array}{l}\text { Peaking factor of 2-D power distribution } \\
\text { in CS }\end{array}$ & $\mathrm{K}_{\mathrm{FA}}-\mathrm{CS}$ & & Maximum in $\mathrm{q}_{\mathrm{k}}$-CS values \\
\hline 2-D power distribution in assembly & $\mathrm{q}_{\mathrm{k}}$ & & $\begin{array}{l}\text { Power of fuel pins normalized by average fuel } \\
\text { pin power in assembly (in some axial fraction). }\end{array}$ \\
\hline 3-D power distribution in axial volumes & $\mathrm{q}_{\mathrm{ijk}}$ & & Power of axial volumes of fuel pins normalized \\
\hline
\end{tabular}

${ }^{a}$ Boron acid concentration divided by the coefficient 5.72 means natural boron (nat B) concentration. In VVER-1000 calculations the term of boron acid concentration is widely used. Below, $\mathrm{Cb}$ means boron acid concentration if there is no special indication. 


\begin{tabular}{|c|c|c|c|}
\hline of fuel pins in core & & & $\begin{array}{l}\text { by average power in such volumes over a whole } \\
\text { core }\end{array}$ \\
\hline Pin power peaking factor in assembly & Kki & & $\begin{array}{l}\text { Among } q_{k} \text { values for an assembly number } i \text { for a } \\
\text { fraction number } j \text { where maximum } q_{i j} \text { for this } \\
\text { assembly is realized. }\end{array}$ \\
\hline Radial pin power peaking factor & $\mathrm{Kr}$ & & $\max (\mathrm{qi} * \mathrm{Kki})$ \\
\hline $\begin{array}{l}\text { Radial position of radial pin power } \\
\text { peaking factor }\end{array}$ & $\mathrm{N}(\mathrm{Kr})$ or $\mathrm{N}_{\mathrm{K}}$ & & $\begin{array}{l}\text { Number of assembly in calculational core } \\
\text { sector where } \mathrm{Kr} \text { is realized }\end{array}$ \\
\hline 2-D power peaking factor in assembly & $\begin{array}{c}\mathrm{K}_{\mathrm{F} \Lambda} \\
\text { (in Russian } \\
\text { exploitation } \\
\text { calculations the } \\
\text { notation } \mathrm{Kk} \text { or } \\
\mathrm{Kk}_{\max } \text { is also } \\
\text { used) }\end{array}$ & & $\begin{array}{l}\text { Maximum relative power of fuel pins } \\
\text { (maximum in } q_{k} \text { values) }\end{array}$ \\
\hline $\begin{array}{l}\text { Axial power peaking factor in assembly } \\
\text { or in fuel pin }\end{array}$ & $\mathrm{Kz}$ & & $\begin{array}{l}\text { Maximum relative power of axial volume in } \\
\text { assembly or in fuel pin normalized by average } \\
\text { power in such volumes (in assembly or in fuel pin) }\end{array}$ \\
\hline Total power peaking factor & Ko or $K_{(- \text {-total }}$ & & $\max \left(\mathrm{q}_{\mathrm{ij}} * \mathrm{Kki}\right)=\mathrm{Kr}^{*} \mathrm{Kz}$ \\
\hline $\begin{array}{l}\text { Radial position of total power peaking } \\
\text { factor }\end{array}$ & $\begin{array}{l}\mathrm{N}\left(\mathrm{K}_{\mathrm{o} \text {-total }}\right) \text { or } \\
\mathrm{N}_{\mathrm{K}}\end{array}$ & & $\begin{array}{l}\text { Number of assembly in calculational core } \\
\text { sector where } \mathrm{K}_{\mathrm{o} \text {-total }} \text { is realized }\end{array}$ \\
\hline $\begin{array}{l}\text { Axial position of total power peaking } \\
\text { factor }\end{array}$ & $\begin{array}{l}\mathrm{M}\left(\mathrm{K}_{\mathrm{o} \text {-total }}\right) \text { or } \\
\mathrm{N}_{\mathrm{Z}}\end{array}$ & & Number of axial level where $\mathrm{K}_{\text {o-total }}$ is realized \\
\hline Engineering factor & $\mathrm{K}_{\text {eng }}$ & & $\begin{array}{l}\text { Coefficient taking account of uncertainty of a } \\
\text { hot point (maximum fuel pin local power) } \\
\text { calculations }\end{array}$ \\
\hline 2-D burnup distribution in assembly & BUk & $\begin{array}{l}\mathrm{MWd} / \mathrm{kg} \\
\text { or } \mathrm{GWd} / \mathrm{t}\end{array}$ & Average-pin burnup distribution in CS. \\
\hline
\end{tabular}




\begin{tabular}{|c|c|c|c|}
\hline 1-D burnup distribution in fuel pin & BUpin & & $\begin{array}{l}\text { Burnup distribution in concentric zones of } \\
\text { equal volume in fuel pin, normalized by average } \\
\text { zone burnup. }\end{array}$ \\
\hline 1-D power distribution in fuel pin & $\overline{q_{p i n}}$ & & $\begin{array}{l}\text { Power distribution in concentric zones of equal } \\
\text { volume in fuel pin, normalized by average zone } \\
\text { power. }\end{array}$ \\
\hline Regulation bank position & $\mathrm{H}_{\text {reg }}$ & $\mathrm{cm}$ & Distance from core bottom till rods lower edge \\
\hline Control rods worth (in core) & $(\mathrm{RO})_{\mathrm{AP}-1}$ & $\mathrm{ppm}$ & $\begin{array}{l}\text { Effect of control rods insertion in core } \\
\text { supposing the most effective single CR stuck in } \\
\text { upper position. } \\
\text { It is defined as a reactivity difference in two } \\
\text { states: } \\
\text { (RO) }{ }_{\mathrm{AP}-\mathrm{l}}=\mathrm{RO} 1-\mathrm{RO} 2 \text {. } \\
\text { The second state differs from the first one only } \\
\text { by additional CRs inserted in core. All the other } \\
\text { parameters correspond to the first state: Cb (that is } \\
\text { equal to Cb crit for the first state), temperature and } \\
\text { FP distribution in core. }\end{array}$ \\
\hline Repeat Criticality Temperature & RCT & ${ }^{\circ} \mathrm{C}$ & $\begin{array}{l}\text { Temperature that ensures a secondary critical state } \\
\text { during core cooling in EOC in such conditions: all } \\
\text { control rods inserted in core except one the most } \\
\text { effective, zero boron concentration, equilibrium } \\
\text { xenon concentration corresponding to reactor } \\
\text { power before its shut-down. }\end{array}$ \\
\hline Moderator temperature coefficient (in core) & MTC & $\mathrm{pcm} /{ }^{\circ} \mathrm{C}$ & \\
\hline Moderator density coefficient (in core) & $\mathrm{MDC}$ & $\mathrm{pcm} / \mathrm{g} / \mathrm{cc}$ & \\
\hline Doppler temperature coefficient (in core) & $\overline{\text { DTC }}$ & $\mathrm{pcm} /{ }^{\circ} \mathrm{C}$ & $\begin{array}{l}\text { Calculated supposing average fuel temperature } \\
\text { changing of } 1{ }^{\circ} \mathrm{C}\end{array}$ \\
\hline $\begin{array}{l}\text { Doppler isotermic temperature coefficient } \\
\text { (in core) }\end{array}$ & DTC* & $\mathrm{pcm} /{ }^{\circ} \mathrm{C}$ & $\begin{array}{l}\text { Calculated supposing local fuel temperature } \\
\text { changing of } 1^{\circ} \mathrm{C}\end{array}$ \\
\hline
\end{tabular}




\begin{tabular}{|c|c|c|c|}
\hline Doppler power coefficient (in core) & $\mathrm{DPC}$ & $\mathrm{pcm} / \mathrm{MW}$ & \\
\hline Boron reactivity coefficient (in core) & $\mathrm{DRO} / \mathrm{DCB}$ & $\mathrm{pcm} / \mathrm{ppm}$ & \\
\hline Effective fraction of delayed neutrons & $\beta$ eff or $\beta_{\text {ef. }}$ & ppm & General characteristic of infinite grid or core \\
\hline Lifetime of prompt neutrons & $l_{m}$ or $l_{i m}$ & $\mathrm{~s}$ & General characteristic of infinite grid or core \\
\hline Reactor thermal power & $\mathrm{W}$ & MW & \\
\hline Specific reactor thermal power in CS & Wv & KW/litre & Reactor thermal power in CS volume unit \\
\hline Nominal reactor thermal power & Wnom & MW & Equal to $3000 \mathrm{MW}$ for VVER-1000 \\
\hline $\begin{array}{l}\text { Minimum controllable level of reactor } \\
\text { power }\end{array}$ & MCL & MW & $\begin{array}{l}\text { In calculations corresponds to Zero Power and } \\
\text { uniform temperature } 280^{\circ} \mathrm{C} \text { in core. }\end{array}$ \\
\hline Core coolant flow rate & $\mathrm{G}$ & $\mathrm{m}^{3} / \mathrm{h}$ & \\
\hline Average entry core temperature & $t_{\text {entry }}$ & ${ }^{\circ} \mathrm{C}$ or $\mathrm{K}$ & \\
\hline Average outer core temperature & $t_{\text {out }}$ & ${ }^{\circ} \mathrm{C}$ or $\mathrm{K}$ & \\
\hline $\begin{array}{l}\text { Average coolant-moderator temperature in } \\
\text { CS }\end{array}$ & $t_{\bmod }$ & ${ }^{\circ} \mathrm{C}$ or $\mathrm{K}$ & \\
\hline Average coolant-moderator density in CS & $\gamma_{\mathrm{mod}}$ & $\mathrm{g} / \mathrm{cm}^{3}$ & \\
\hline Fuel temperature & $t_{\text {fuel }}$ & $\mathrm{K}$ & \\
\hline $\begin{array}{l}\text { Average temperature of other } \mathrm{CS} \\
\text { components }\end{array}$ & $t_{\text {con }}$ & ${ }^{\circ} \mathrm{C}$ or $\mathrm{K}$ & \\
\hline Fuel pin cladding temperature & $t_{\text {clad }}$ & ${ }^{\circ} \mathrm{C}$ or $\mathrm{K}$ & \\
\hline $\begin{array}{l}\text { Xenon-135 concentration distribution in } \\
\text { core }\end{array}$ & $\mathrm{Xe}$ & $10^{24} / \mathrm{cc}$ & $\begin{array}{l}\text { For } 1 \mathrm{cc} \text { in fuel. } \\
\mathrm{Xe}=0 \rightarrow \text { xenon is absent; } \\
\mathrm{Xe}=1 \rightarrow \mathrm{Xe}=\mathrm{Xe} \text { eq }(\mathrm{W})\end{array}$ \\
\hline $\begin{array}{l}\text { Equilibrium Xenon-135 concentration } \\
\text { distribution in core }\end{array}$ & Xe eq $(W)$ & $10^{24} / \mathrm{cc}$ & $\begin{array}{l}\text { Concentration formed during long working with } \\
\text { W power, regulating bank in nominal position }{ }^{b}\end{array}$ \\
\hline Sm-149 concentration distribution in core & $\mathrm{Sm}$ & $10^{24} / \mathrm{cc}$ & $\begin{array}{l}\text { For } 1 \mathrm{cc} \text { in fuel. } \\
\mathrm{Sm}=0 \rightarrow \text { samarium is absent, } \\
\mathrm{Sm}=1 \rightarrow \mathrm{Sm}=\mathrm{Sm} \text { eq, } \\
\mathrm{Sm}=3 \rightarrow \text { full decay of } \mathrm{Pm}-149 \text { into } \mathrm{Sm}-149 \text { is }\end{array}$ \\
\hline
\end{tabular}

\footnotetext{
${ }^{\mathrm{b}}$ In VVER-1000 calculations Hreg in nominal position is equal to $80 \%$ if there is no special indication
} 


\begin{tabular}{|c|c|c|c|}
\hline & & & simulated in BOC. \\
\hline $\begin{array}{l}\text { Equilibrium } \mathrm{Sm}-149 \quad \text { concentration } \\
\text { distribution in core }\end{array}$ & Sm eq & $10^{24} / \mathrm{cc}$ & $\begin{array}{l}\text { Concentration formed during long working, } \\
\text { regulating bank in nominal position }\end{array}$ \\
\hline $\begin{array}{l}\text { Samarium-149 concentration distribution, all } \\
\text { Prometium-149 decayed in } \mathrm{Sm}\end{array}$ & Smh & $10^{24} / \mathrm{cc}$ & \\
\hline Core reactivity while reactor shut-down & $\overline{\mathrm{RO}_{\text {STOP }}}$ & $\mathrm{pcm}$ & $\begin{array}{l}\text { Under conditions: } \mathrm{W}=0, \mathrm{Xe}=0, \mathrm{Sm}=\mathrm{Smh}, \\
\mathrm{t}_{\text {mod }}=\mathrm{t}_{\text {fuel }}=\mathrm{t}_{\mathrm{con}}=20^{\circ} \mathrm{C} \\
\mathrm{Cb}=16000 \mathrm{ppm}\end{array}$ \\
\hline
\end{tabular}




\section{Parametric Studies of MOX LTA design (Stage "Assembly")}

\subsection{Calculational Model}

Calculational system (CS) for MOX LTA design parametric studies is presented by the infinite grid with the following periodical element:

- central plutonium assembly surrounded by uranium assemblies of $3.7 \% \mathrm{Wt}$. U235. The $60^{\circ}$ sector of CS is shown in Figure 2.6.

Composition of weapons grade plutonium, adopted for calculations, is presented in Table 2.1. The design parameters of plutonium and uranium assemblies are described in Tables 2.2-2.6.

Two limitations has been adopted while defining an acceptable MOX FA zoning (fissile plutonium distribution in a fresh MOX FA):

- power peaking factor in CS is conventionally limited by the value of 1.1. It is supposed that under such condition the global power peaking factors in core calculations could be rested in acceptable range described in Chapter 4.

- minimum allowable fissile plutonium enrichment (Pu-239 and $\mathrm{Pu}-241)$ is equal to $2 \%$ according to technological considerations.

\subsubsection{Fuel Irradiation Simulation}

This regime is used for MOX LTA zoning studies under the conditions described in [2]. They comprise irradiation simulation in CS as a rule on the interval $[0-40 \mathrm{MWd} / \mathrm{kg}]$ with the step $2 \mathrm{MWd} / \mathrm{kg}$.

In the process of irradiation:

- $\quad$ Axial buckling is $1 . \mathrm{E}-4 \mathrm{~cm}^{-2}$;

- $\quad \mathrm{Cb}$ (nat $\mathrm{B})=600 \mathrm{ppm}$. A set of calculations for zero irradiation has been executed with $\mathrm{Cb}=0$ and $\mathrm{Cb}$ (nat.B) $=1200 \mathrm{ppm}$;

- $\quad \mathrm{Wv}=108 \mathrm{KW} / \mathrm{litre}$;

- $\quad \mathrm{t}_{\bmod }=302^{\circ} \mathrm{C}$;

- $\quad t_{\text {con }}=302^{\circ} \mathrm{C}$;

- $\quad \mathrm{t}_{\text {fuel }}=1027 \mathrm{~K}$;

- $\mathrm{Xe}=\mathrm{Xe}$ eq;

- $\quad \mathrm{Sm}=\mathrm{Sm}$ eq.

\subsubsection{Zero Power Calculations}

This regime is aimed to define reactivity effects due to temperature and $\mathrm{Cb}$ variations and to compare Keff with eventual verification calculations to be carried out by other codes. 
Calculations are executed in five irradiation points:

$0,10,20,30,40 \mathrm{GWd} / \mathrm{t}$

where states are to be formed by different combinations of the following values:

$\mathrm{Cb}$ (nat.B): $0,600,1200 \mathrm{ppm}$;

$\mathrm{t}_{\text {mod }}=\mathrm{t}_{\text {con }}=\mathrm{t}_{\text {fuel }}: 20,280^{\circ} \mathrm{C}$.

\subsection{Results}

\subsubsection{Zoning Parametric Studies}

Zoning parametric studies consisted in variation of fissile plutonium content in 3zones MOX LTA (Figures 2.5 and 2.6).

The results of calculations simulating fuel irradiation in plutonium and uranium assemblies are presented in Tables $2.8-2.13$. Two options of Uranium reference assembly are considered:

- without BPR i.d. with guide tubes filled by water in 18 positions in assembly (see for example Fig.2.1);

- $\quad$ with BPRs of properties presented in Table 2.6.

It can be seen that $2 \%$ fissile plutonium content in periphery entails significantly lower values of power peaking factor "Kkmax-CS" than $2.4 \%$ content (compare Tables 2.10 and 2.11 ). That is why $2 \%$ content in periphery has been adopted. Plutonium content in the central and intermediate zones was variable to obtain Ko value similar to reference uranium CS.

Finally the plutonium content of $4.2 / 3.0 / 2.0$ has been chosen as acceptable. The Ko evolution in the process of fuel irradiation for the reference uranium and different plutonium assemblies is shown in Figure 2.8*.

Fig.2.9 shows "Kkmax-CS" evolution in the process of irradiation. The increase of "Kkmax-CS" for 3-zones MOX LTAs is observed from a certain moment. As it is seen from the Table 2.13 and Figure 2.6, during irradiation maximum CS power passes from uranium pins out of MOX LTA to the interior of MOX LTA. This effect should be studied in future more attentively taking into account that in real conditions a fresh MOX LTA will be surrounded by both fresh and irradiated uranium assemblies that can lead to mitigating of the mentioned effect. It will be seen in Chapter3.

\footnotetext{
"The results for "Island" type MOX LTA [10] are also presented in Figures 2.8 and 2.9.
} 
RUSSIAN RESEARCH CENTER KURCHATOV INSTITUTE

Design Studies of "100\%Pu" MOX Lead Test Assembly (Report for FY99)

\subsubsection{Zero Power Calculations}

The results of calculations are presented in Table 2.7. It may be seen that the positive temperature reactivity effect appears for the great boron concentrations of $1200 \mathrm{ppm}$. In MOX LTA this effect is lower owing to more absorbable properties of MOX fuel as compared with uranium one. 


\section{Parametric Studies of MOX LTA design (Stage "Core Fragments")}

In these calculations the simplest core design was considered (without BPRs in FAs).

\subsection{Description of calculational model}

The pattern for the core of VVER-1000 with FA lifetime of three years and partial (1/3 of FAs) MOX loading, under steady-state operation at the beginning of cycle, is as follows: 1 fresh MOX assembly - 1 MOX FA having operated for 1 year - 1 MOX FA having operated for 2 years - 2 fresh $\mathrm{UO}_{2} \mathrm{FAs}$, and $\mathrm{UO}_{2}$ FAs taken two at a time having operated for 1 and 2 years, respectively. Thus, the symmetric element of the core contains 9 FAs. This symmetric element is shown in Fig.3.1. The use of this symmetric element makes it possible to study various ways for arrangement of positions of MOX and uranium FAs with different burnups. In this case, a correct normalization of power distribution is achieved.

It should be noted that Fig.3.1 shows only one of possible variants of symmetric element configuration. The model allows us to consider any one of other regular core configurations.

The graded uranium FA shown in Fig.2.1 (so-called reference uranium FA) was used as UOX FA.

The three-zones FA with MOX fuel was used as MOX FA. The map of this FA is shown in Fig.2.5.

At the first stage of calculations the core parameters during burnup were taken the same as those at the stage "Assembly" (Chapter 2):

$$
\begin{aligned}
& \mathrm{C}_{\mathrm{B}} \text { (nat. B) }=600 \mathrm{ppm}, \\
& \mathrm{W}_{\mathrm{V}}=108 \mathrm{KWt} / \mathrm{l} \\
& \mathrm{t}_{\text {mod }}=302{ }^{\circ} \mathrm{C} \\
& \mathrm{t}_{\text {fuel }}=1027 \mathrm{~K} .
\end{aligned}
$$

The axial buckling was taken to be zero.

At the second stage of calculations the axial buckling was determined on condition that the $K_{\text {eff }}$ value of system is equal to one at the end of cycle and with zeroth boron concentration in water. The initial boron concentration is equal to $1200 \mathrm{ppm}$ and this value approximately corresponds to initial boron concentration in VVER-1000 core with partial (1/3) MOX fuel loading (in terms of boron acid concentration it corresponds to $6864 \mathrm{ppm}$ - compare with the values in Tables 4.7, 4.9 and 4.11)

Power distribution calculation during burnup and reloading simulation were made with the use of IPPE code complex TRIANG-PWR in two-group diffusion approximation. Macroconstant calculations were performed by the WIMS-ABBN code that is the updating version of the well-known English WIMS-D4 code. 


\section{RUSSIAN RESEARCH CENTER KURCHATOV INSTITUTE \\ Design Studies of "100\%Pu” MOX Lead Test Assembly (Report for FY99)}

When constructing the calculational model, it was assumed that fuel rods in FA are divisible into several groups (inner fuel rods, corner rods, periphery ones of 1-st row and so on) with the aim to describe the differences in regions surrounding fuel rods (water holes, inter-assembly water). Cell burnup calculations for macroconstant preparation were carried out with the use of these groups. Assessment of calculational error in pin-by-pin power distribution with the use of TRIANG code and indicated procedure of macroconstant preparation was made in [9] by comparison with calculations performed using the benchmark multigroup CONKEMO code based on the Monte Carlo method for neutron flux calculation. Burnups were studied for models with graded and non-graded MOX FAs surrounded by $\mathrm{UO}_{2}$ FAs. Maximum discrepancy in pin-by-pin power distribution in both cases was demonstrated to do not exceed $5 \%$ for all burnup steps.

\subsection{Results of the first stage study}

\subsubsection{Boundary condition effect}

As noted above, periodic boundary conditions was realized in TRIANG code with the aim to describe the given models properly in the case that the outer system boundary is regular hexagon. Table 3.1 gives the calculational results of power peaking factors for six FA arrangements (see Fig.3.2) with graded MOX FAs shown in Fig.2.5.

For each variant the first two lines are related to uranium core model, the second two lines apply to 1/3 MOX FAs core model. The first line gives the values for reflection boundary conditions, the second one gives the data for periodic boundary conditions. As evident from the Table 3.1, the error in power peaking factor due to incorrect boundary conditions may be as much as $18 \%$. In what follows that the calculation results should be obtained with the use of periodic boundary conditions.

\subsubsection{Effect of plutonium content in MOX FAs on power non-uniformity}

The calculations have shown that for all FA arrangement variants given in Table 3.1 with MOX fuel zoning from Chapter $2(4.2 / 3.0 / 2.0)$ the fuel elements with maximum power are positioned in FAs with UOX fuel, and power peaking factors in $1 / 3$ MOX FA core model are higher than these values in core model with $\mathrm{UO}_{2}$ fuel.

In this connection in addition to $4.2 / 3.0 / 2.0$ (average content of fissile $\mathrm{Pu}$ is $3.34 \%$ ) six supplemental variants of fuel zoning have been considered: $4.4 / 3.2 / 2.0$; $4.5 / 3.3 / 2.1 ; 4.6 / 3.4 / 2.2 ; 4.7 / 3.5 / 2.3 ; 4.8 / 3.6 / 2.4 ; 4.9 / 3.7 / 2.5$. The average contents of fissile $\mathrm{Pu}$ are $3.5 ; 3.6 ; 3.7 ; 3.8 ; 3.9 ; 4.0$ respectively. For these cases Fig. 3.3 demonstrates dependence of $K_{K}-C S\left(\right.$ or $\left.K_{K \max }-C S\right)$ and $K_{K}-C A$ (or $K_{K \max }-C A$ ) on $\mathrm{Pu}$ content, here

$K_{K m a x}-C A \quad(C A$ - central assembly) is the maximum fuel element power in the central FA with normalization to the average value over the system. 


\section{RUSSIAN RESEARCH CENTER KURCHATOV INSTITUTE Design Studies of “100\%Pu” MOX Lead Test Assembly (Report for FY99)}

As is seen from the figure in variants V1-V3, the $K_{K \max }-C S$, already having rather low values, with a rise of $\mathrm{Pu}$ content is reduced and the $K_{K \max }-C A$ increases, i.e. power distribution is flattening. In this case the maximum values of fuel element power in uranium and MOX FAs come close together as fissile Pu content becomes equal to about $4.3 \%$.

In variants V4-V5 the $K_{K \max }-C S$ and $K_{K \max }-C A$ come closer together rather rapidly and even at $\mathrm{Pu}$ contents of $3.9 \%$ and $3.8 \%$ respectively they level off, i.e. maximum power peaking factor moves to the MOX FA and remains there with further $\mathrm{Pu}$ content increasing. Variant V6 is identical to the variant V5.

It is seen that in the variant V5, having the worst $K_{K \max }-C S$ curve, the minimum value of $K_{K \max }-C S$ is achieved at Pu content of about $3.7 \%$. Therefore, the further study was done using MOX FAs with average fissile Pu content of $3.7 \%$.

\subsubsection{Effect of plutonium zoning in MOX FAs on power non-uniformity}

Table 3.2 gives the power peaking factors for non-zoned MOX FAs. It is clear that in this case maximum power peaking factors are very high even for the variants with relatively flat power distribution. To choice optimal $\mathrm{Pu}$ zoning the calculations of each of six arrangements with four various zoning variations (4.4/3.4/2.6; 4.5/3.4/2.4; 4.6/3.4/2.2; 4.7/3.4/2.0) were carried out. All four variations give average fissile Pu content equal to 3.7\%. In Tables 3.3-3.6 the power peaking factors over the whole system, over the central FA and average power peaking factors in central FA are listed. The FA burnup non-uniformity was neglected in these calculations. As is seen from Tables 3.3-3.6, the least maximum peaking factors over the whole system are achieved at zoning of 4.6/3.4/2.2.

\subsubsection{Refinement of the results with consideration for FA burnup non-uniformity and fuel reloadings}

Generally speaking, one should take account of the individual burnup in each fuel element. However with the aim of saving the computation time it was decided to separate the central part of FA, and periphery was divided into 6 sectors (of four regions each) simulating FA zoning, among them corner fuel elements taking individually. Altogether there are 25 burning regions per FA. A choice of such model follows from analysis of power distributions at initial state showing that maximum discrepancies from average values are equal to $2 \%$ in each region separated. In doing so, it should be remembered that power distribution is flattening during burnup.

Figure 3.4 shows FA arrangements considered and the conventional three-digit numbers used by TRIANG code complex for simulation of FA reloadings. The first digit shows FA operating years, the next two digits are used for numbers of FAs of each operating year. In this case uranium FAs have numbers 1 and 2, and MOX FA has number 3 . 


\section{RUSSIAN RESEARCH CENTER KURCHATOV INSTITUTE \\ Design Studies of "100\%Pu" MOX Lead Test Assembly (Report for FY99)}

Table 3.7 represents FA reloading schemes possible within the limits of a given symmetry element. Table 3.8 gives power peaking factors for equilibrium fuel cycle for all four possible reloading schemes. MOX FA with $x_{p_{u} f}=4.6 \% / 3.4 \% / 2.2 \%$ is used in all cases.

The data given in Table 3.8 allow us to make following conclusions. Firstly, the largest values of power peaking factors in equilibrium fuel cycle occur at the cycle beginning. Secondly, variations in fuel reloading scheme do not markedly affect the run of power peaking factor during burnup. Comparing the data of Tables 3.5 and 3.8, one can see that the maximum increase of power peaking factor $K_{K \max }-C S$ due to burnup non-uniformity and fuel reloading simulation is about $2 \%$.

\subsection{Results of the second stage study}

On the second stage of calculations the boron concentration during burnup was taken as linearly decreasing from $1200 \mathrm{ppm}$ at the cycle beginning to zero at the cycle end. Axial buckling was defined when $\mathrm{K}_{\mathrm{eff}}=1$ at the cycle end and with zeroth boron concentration.

The graded MOX FA with $\bar{x}_{P u^{f}}=3.34 \%$ was taken as a basis for calculations. In the new set of calculational variants the fissile $\mathrm{Pu}$ content were either reduced or increased by $0.1 \%$ in all zoning regions simultaneously. A set of average Pu content was as follows: $x_{P_{u} f}=3.04 \%, 3.14 \%, 3.24 \%, 3.34 \%, 3.44 \%$, and $3.54 \%$.

For three FA arrangements, namely, V1, V4 and V6 the calculations were carried out with regard to fuel reloadings. Six burnup cycles were simulated. Fig. 3.5 shows the $K_{K \max }-C S$ and $K_{K \max }-C A$ values for the initial zeroth and the last fifth cycles. It is seen from Fig. 3.5 that maximum in power peaking factor in V1 and V4 moves to uranium FAs at $x_{P_{u} f} \leq 3.44 \%$. In V6 variant the maximum value remains in MOX FA even with $\bar{x}_{P u^{f}}$ reducing to $3.14 \%$. It is also seen that dependence of $K_{K \max }-C S$ and $K_{K \max }-C A$ on $x_{P u^{f}}$ and position of optimum in zeroth and last cycles are practically the same. A consideration of fuel reloadings and burnup non-uniformity causes power peaking factors to increase by $2-3 \%$. It allows us to make an estimate of $\mathrm{Pu}$ content using only one burnup cycle.

In the mentioned above set of calculations the optimum $\mathrm{Pu}$ content distribution over the zoning regions in MOX FA was not under control. In the next set of calculations $\mathrm{Pu}$ content distribution over the zoning regions was corrected for each $\bar{x}_{P u}$ to meet conditions of maximum power equivalence in fuel elements in these regions. Calculations were carried out for zeroth fuel reloading.

Fig. 3.6 gives dependence of power peaking factors on $\mathrm{Pu}$ content for the last set of calculations (continuous lines) and for previous one (dotted lines). Refined values of $K_{K \max }-C S$ computed for fifth reloading at $x_{P^{\prime} u^{\prime}}=3.51 \%$ are shown for each variant with separate points.

From Fig. 3.3 and Fig. 3.6 it follows that the use in calculations of actual boron content in water caused the optimum Pu concentration in MOX FA to reduce. This is because an increase of boron content tends to reduced power of uranium FA as compared with MOX FA on account of significantly larger thermal neutron capture in MOX FAs. This effect is most pronounced in fresh FAs. 
From Fig. 3.6 it also follows that an optimum content of fissile Pu in MOX FAs with weapons-grade plutonium at which maximum fuel element powers in MOX and uranium $\left(\bar{x}_{5}=3.6 \%\right)$ FAs are equal is about $3.5 \%$. In this case optimum $\mathrm{Pu}$ content distribution in zoning regions is as follows: $x_{p_{u}}=4.3 \% / 3.3 \% / 2.1$ (for fuel element positions in graded MOX FA shown in Fig. 2.5). The $K_{K \max }-C S$ values are equal about to 1.30 and 1.40 in V1-V3 and V4-V6 variants, respectively. Fig. 3.7 shows power distributions for six studied fuel arrangements in an optimum case.

It should be noted that in the case of the use of boron burnable rods or fuel elements with gadolinium the relative reduction of power in uranium FA takes place. It tends to further reduction of optimum Pu content in MOX FA as compared with U-235 content in uranium FAs.

On the other hand, calculational estimates of Pu content in MOX FA that is equivalent in cycle duration to uranium FA with $\bar{x}_{5}=3.6 \%$ give the $\bar{x}_{P_{u}} r$ value equal to $3.9 \%$.

\section{Conclusion on Chapter 3}

1. The refinements of the model for symmetric element calculations have been introduced. They involve

- periodic boundary conditions instead of reflection conditions on outer boundaries,

- taking into account burnup non-uniformity and FA reloadings.

2. The error in power peaking factor due to incorrect boundary conditions was demonstrated to be as much as $18 \%$. Taking into account fuel reloadings and burnup non-uniformity causes power peaking factor to increase by $2-3 \%$.

3. Taking account of actual instead of average boron content in water tends to reduction of optimum Pu concentration in MOX FA, at which maximum fuel element powers in MOX and uranium FAs are equal. This is because an increase of boron content tends to reduced power of uranium FA as compared with MOX FA on account of significantly larger thermal neutron capture in MOX FA. This effect is most pronounced in fresh FAs.

4. Optimum $\mathrm{Pu}$ content in MOX FA from the standpoint of power distribution flattening is about $3.5 \%$ with U-235 content in uranium FAs of $3.6 \%$. In this case optimum $\mathrm{Pu}$ content distribution on zoning regions is as follows: $x_{P_{u^{\prime}}}=4.3 \% / 3.3 \% / 2.1 \%$ (for fuel element positions in graded MOX FA shown in Fig. 2.5).

Pin-by-pin power peaking factor varies between 1.3 and 1.4 depending on FA arrangements.

5. Results given above apply to the simplest design of core, in which boron burnable rods and fuel elements with gadolinium are unused. The use of boron burnable rods or fuel elements with gadolinium in FAs will result in further reduction of optimum Pu content in MOX FAs as compared with U-235 content in FAs with uranium fuel. Hence, given model considerations couldn't be proposed as final recommendation on zoning choice. Just the same, they are useful for establishing regular trends, 
RUSSIAN RESEARCH CENTER KURCHATOV INSTITUTE

Design Studies of "100\%Pu" MOX Lead Test Assembly (Report for FY99)

comparing different computer codes and choosing preliminary zoning. The final choice of fuel zoning can be only done by means of pin-by-pin power distribution calculations in reactor having regard to actual FA composition of fuel and burnable poison.

6. The Pu content in MOX FA that is equivalent to uranium FA with $\bar{x}_{5}=3.6 \%$ in cycle duration is equal to $\bar{x}_{P_{u}}=3.9 \%$. 


\section{CALCULATIONS OF VVER-1000 CORE WITH 3 MOX LTAs (Stage "Core")}

These studies comprise:

- "Uranium Core". Calculation of the so-called Advanced VVER-1000 core with boron BPRs for the equilibrium fuel cycle [2] that was defined as basic for 3 MOX LTAs introduction.

- "MOX Core". Studies of VVER-1000 core with introduction of 3 LTAs of " $100 \% \mathrm{Pu}$ " design with the zoning chosen in Chapter 2 . Three cycles till MOX LTAs discharge have been studied. Corresponding loading patterns for every cycle have been chosen to minimize power peaking factors.

"Uranium core" loading pattern is shown in Fig.4.1. This figure includes particularly the reloading scheme (the FA locations in previous fuel cycle are indicated), the FA locations in current equilibrium cycle with the indication of its type (according to Figures 2.1, 2.3 and 2.4) and initial average assembly burnups.

The core, FA, fuel pins, CR and Boron BPR geometric and material parameters are indicated in Tables 2.1-2.6.

The reflectors are described in Annex.

\subsection{Limitations}

\section{Safetv limitations}

Composed core loading patterns must meet a number of safety requirements.

Tables 4.1 and 4.2 present the requirements that are officially adopted nowadays for VVER-1000 Uranium cores.

For MOX fueled cores the limitations, not yet officially established, have been conventionally strengthened for power peaking factors and RCT. They are presented in Tables 4.3 and 4.4. It was tried to meet these conventional requirements either for MOX LTAs only (it concerns power peaking factors) or for the core (it concerns RCT).

\section{Other limitations}

3 MOX LTA are placed in the core under the following conditions:

- respect $120^{\circ}$ symmetry;

- not to occupy the positions without in-core measurement system (the self-powered detectors are shown in Fig. 4.6);

- it is desirable to place MOX assemblies symmetrically to the uranium ones that are equipped by detectors. 


\subsection{Fuel Irradiation Simulation}

Irradiation of the fuel loading is simulated with the step 20 EFPD. $\mathrm{Cb}$ crit is found in sequence (below these values are named " $\mathrm{Cb}$ burnup") until reactivity margin reaches 0 , i.e. $\mathrm{Cb}$ crit becomes 0 . This moment defines $\mathrm{T}$ cycle - a value of cycle length usually presented in EFPD unit.

In the process of irradiation:

- Regulating Bank N 10 (Figure 4.6) is $20 \%$ inserted in core; other banks are out of core;

- $\mathrm{W}=\mathrm{Wnom}(3000 \mathrm{MW})$;

- $t_{\text {entry }}=287^{\circ} \mathrm{C}$;

- $\mathrm{Xe}=\mathrm{Xe}$ eq;

- At the beginning of irradiation $\mathrm{Sm}=\mathrm{Smh}$.

At the stage "MOX core", while studying of acceptable MOX location in the Uranium loading pattern (Fig.4.1), calculations of three successive cycles are carried out with corresponding description of reloading scheme.

\subsection{Calculational States}

The states that are considered at the stage "Core" are characterized by:

- CRs positions in core (X\% $\mathrm{N} \downarrow$ means that the Bank $\mathrm{N}$ is $\mathrm{X} \%$ inserted in core). No indication means that all the CRs are out of the core;

- $\mathrm{Cb}$;

- Average FP concentration in core (Xe-135 and Sm-149 poisoning are considered separately);

- Xe;

- Sm;

- W (in these studies two power levels are considered - $\mathrm{W}_{\text {nom }}$ и $\mathrm{MCL}$ );

- $\mathrm{t}_{\mathrm{mod}}$

- $t_{\text {fuel; }}$

- $t_{\text {con }}$.

It is necessary to remark that three last parameters are not generally independent.

All the states considered in the process of irradiation will be named "Burn-up".

The specific moments are introduced: the beginning of cycle $(\mathrm{BOC})$ and the end of cycle (EOC). They characterize FP concentration (average in core) in these moments. It should be noted that the other above-mentioned parameters are not 
RUSSIAN RESEARCH CENTER KURCHATOV INSTITUTE

Design Studies of “100\%Pu” MOX Lead Test Assembly (Report for FY99)

always connected directly with irradiation conditions in these moments; their values may depend on reactor start-up conditions before irradiation or cooling conditions in the end of irradiation. 
RUSSIAN RESEARCH CENTER KURCHATOV INSTITUTE Design Studies of "100\%Pu" MOX Lead Test Assembly (Report for FY99)

\subsection{Information Release}

The table below presents the states considered and the parameters calculated. The second column indicates the list of results presented in this report. The rest of calculated parameters and additional information can be received by addressing to Youri Styrine (email: Youri.Styrine@vver.kiae.ru). 
RUSSIAN RESEARCH CENTER KURCHATOV INSTITUTE

Design Studies of "100\%Pu" MOX Lead Test Assembly (Report for FY99)

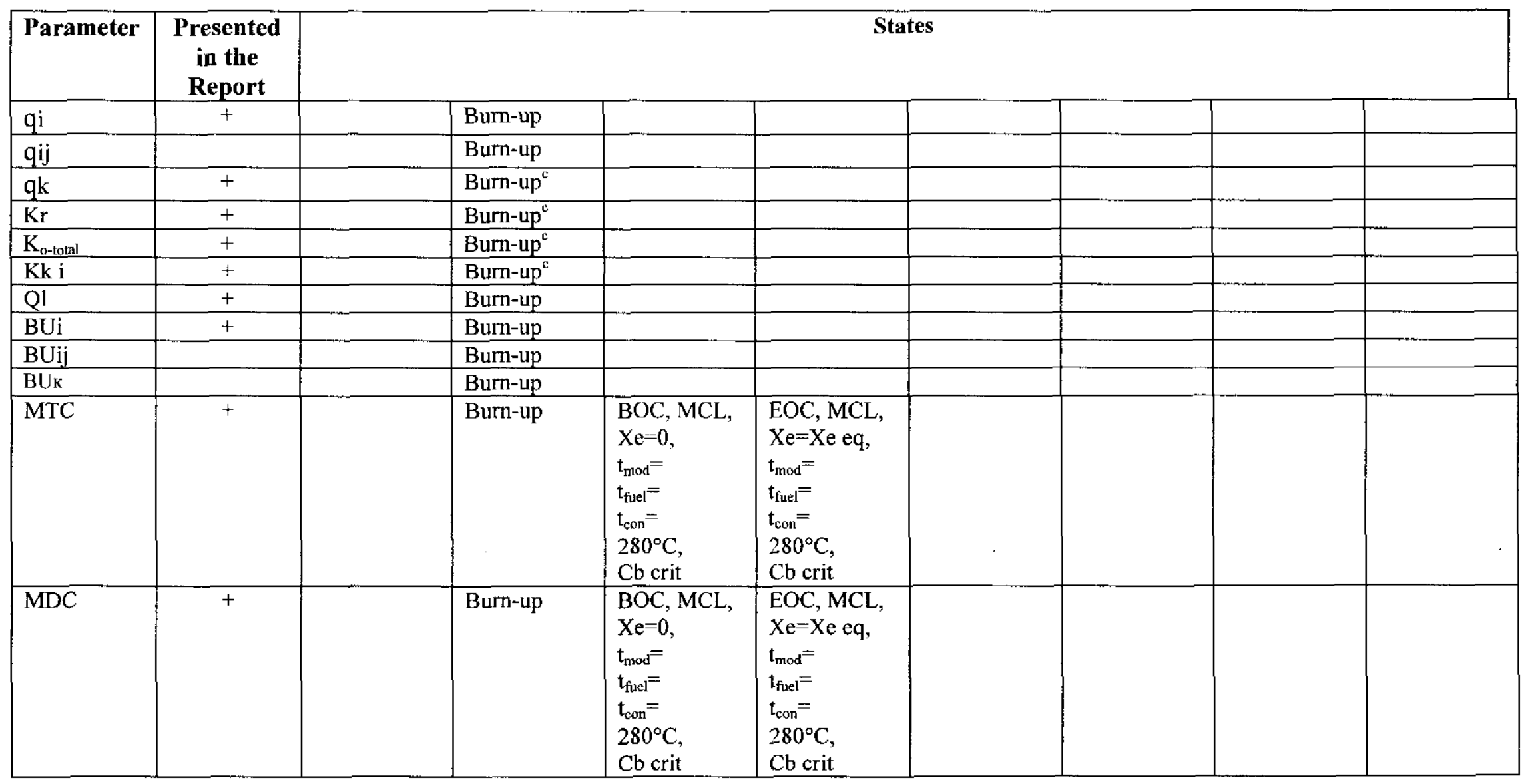

\footnotetext{
${ }^{c}$ For MOX assemblies and for an assembly with maximum qi.

${ }^{\mathrm{c}}$ For MOX assemblies and for an assembly with maximum qi.

${ }^{c}$ For MOX assemblies and for an assembly with maximum qi.

${ }^{c}$ For MOX assemblies and for an assembly with maximum qi.
} 


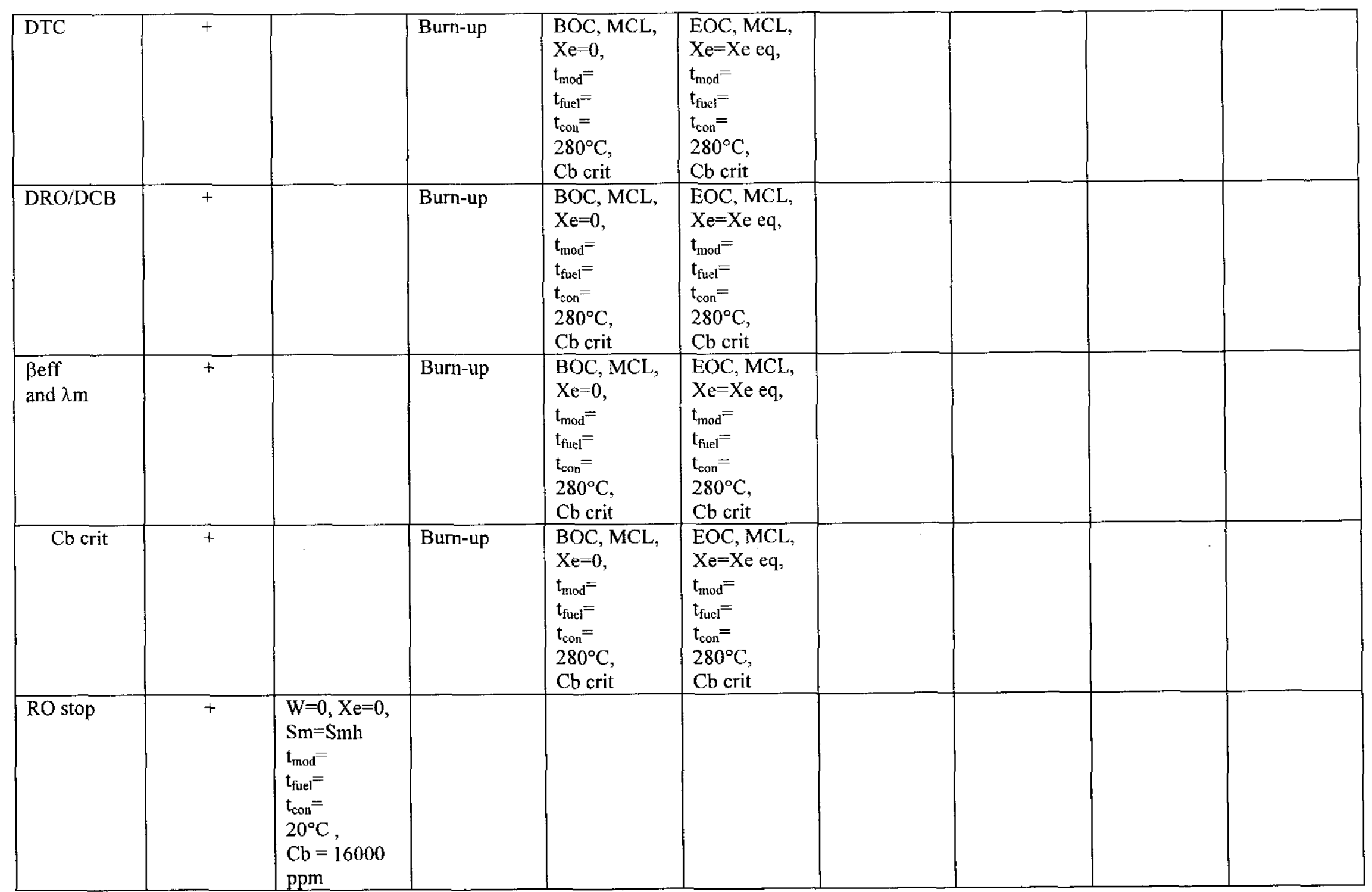




\begin{tabular}{|c|c|c|c|c|c|c|c|c|c|}
\hline RCT & + & $\begin{array}{l}\mathrm{EOC}, \mathrm{MCL}, \\
\mathrm{Xe}=\mathrm{Xe} \text { eq, } \\
\mathrm{t}_{\text {mod }}= \\
\mathrm{t}_{\text {fuel }}= \\
\mathrm{t}_{\text {con }}= \\
280^{\circ} \mathrm{C}, \\
\mathrm{Cb}=0, \\
100 \% 1-10 \downarrow \\
\text { (except of the } \\
\text { most effective } \\
\text { single CR) }\end{array}$ & & & & & & & \\
\hline$(\mathrm{RO})_{\mathrm{AP}-1}$ & + & $\begin{array}{l}\mathrm{S} 1: \mathrm{BOC}, \\
\text { Wnom, } \\
\mathrm{Xe}=\mathrm{Xe} \mathrm{eq}, \\
\mathrm{t}_{\text {ennry }}=287^{\circ} \mathrm{C}, \\
\mathrm{Cb} \text { bumup } \\
100 \% 5 \downarrow \\
30 \% 10 \downarrow \\
\mathbf{S} 2^{\mathrm{b}}: \text { the same } \\
\text { but } \\
100 \% 1-10 \downarrow\end{array}$ & $\begin{array}{l}\text { S1:BOC, } \\
\text { MCL, } \\
\mathrm{Xe}=0, \\
\mathrm{t}_{\mathrm{cuntr}}=280^{\circ} \mathrm{C} \\
\mathrm{Cb} \text { crit } \\
30 \% 10 \downarrow \\
\text { S2: the same } \\
\text { but } \\
100 \% 1-10 \downarrow\end{array}$ & $\begin{array}{l}\text { S1:BOC, } \\
\mathrm{MCl} \text {, } \\
\mathrm{Xe}=\mathrm{Xe} \mathrm{eq}, \\
\mathrm{t}_{\text {entry }}=280^{\circ} \mathrm{C} \\
\mathrm{Cb} \mathrm{crit} \\
30 \% 10 \downarrow \\
\text { S2: the same } \\
\text { but } \\
100 \% 1-10 \downarrow\end{array}$ & $\begin{array}{l}\text { S1:EOC, } \\
\text { Wnom, } \\
\text { Xe=Xe eq, } \\
t_{\text {entry }}=287^{\circ} \mathrm{C} \\
\mathrm{Cb} \text { bumup } \\
100 \% 5 \downarrow \\
30 \% 10 \downarrow \\
\text { S2: the same } \\
\text { but } \\
100 \% 1-10 \downarrow\end{array}$ & $\begin{array}{l}\text { S1:EOC, } \\
\text { MCL, } \\
\text { Xe }=\text { Xe eq, } \\
t_{\text {entry }}=280^{\circ} \mathrm{C} \\
\mathrm{Cb} \text { crit } \\
100 \% 5 \downarrow \\
30 \% 10 \downarrow \\
\text { S2: the same } \\
\text { but } \\
100 \% 1-10 \downarrow\end{array}$ & $\begin{array}{l}\text { S1:EOC, } \\
\text { MCL, } \\
\text { Xe=0, } \\
\mathrm{t}_{\text {enry }}=280^{\circ} \mathrm{C} \\
\mathrm{Cb} \text { crit } \\
100 \% 5 \downarrow \\
30 \% 10 \downarrow \\
\mathrm{S} 2: \text { the same } \\
\text { but } \\
100 \% 1-10 \downarrow\end{array}$ & $\begin{array}{l}\text { S1:BOC, } \\
\text { Wnom, } \\
\text { Xe=Xe eq, } \\
\text { tenry }=287^{\circ} \mathrm{C} \text {, } \\
\mathrm{Cb} \text { bumup } \\
20 \% 10 \downarrow \\
\text { S2: the same } \\
\text { but with } \\
\text { successive } \\
\text { introduction of } \\
\text { the Banks } 1-9 \\
(0 \% \downarrow, 10 \% \downarrow \text {, } \\
20 \% \downarrow \ldots \\
100 \% \downarrow)\end{array}$ & $\begin{array}{l}\text { S1:EOC, } \\
\text { Wnom, } \\
\text { Xe=Xe cq, } \\
t_{\text {entry }}=287^{\circ} \mathrm{C} \\
\mathrm{Cb} \text { burnup } \\
20 \% 10 \downarrow \\
\text { S2: the same } \\
\text { but with } \\
\text { successive } \\
\text { introduction of } \\
\text { the Banks } 1-9 \\
(0 \% \downarrow, 10 \% \downarrow \\
20 \% \downarrow \ldots \\
100 \% \downarrow)\end{array}$ \\
\hline
\end{tabular}

\footnotetext{
${ }^{b}$ For all the states $\mathrm{S} 2$ : the most effective single $C R$ is supposed stuck in upper position.
} 


\subsection{Calculational Results}

\subsubsection{Uranium Core}

The Table 4.5 and Fig. 4.1 show the results of kinetics parameters calculations for the equilibrium fuel cycle in the Uranium base core that have been performed by the code BIPR-7A'.

The attained power peaking factors obtained by pin-by-pin code PERMAK-A are presented in Table 4.13. The linear pin powers for BOC and EOC are presented correspondingly in Figures 4.2 and 4.3. It is seen from combination of BIPR-7A and PERMAK-A calculations that maximum linear pin power in BOC is attained on level $4^{\mathrm{b}}$, in EOC - on level 2. It justifies PERMAK-A calculations to be performed as usual on level 4 (more details about PERMAK-A calculational scheme are described in Annex).

Pin-by-pin power distributions in the most powered assembly for BOC and EOC are presented correspondingly in Figures 4.4 and 4.5.

Table 4.6 shows the parameters values in zero power states calculated by the code BIPR-7A.

It is seen that Uranium core meets the safety requirements presented in Tables 4.1 and 4.2 for power peaking factors and reactivity coefficients.

Table $4.15 \mathrm{a}$ and $4.15 \mathrm{~b}$ show the $\mathrm{CRs}$ worth calculated with certain conservatism (the lowest possible position of Bank 5 that serves for offset regulation and of regulating Bank 10). It is seen that the limiting value of $5500 \mathrm{pcm}$ (Table 4.1) is respected.

Table 4.16 shows core reactivity evolution in the process of control rods simultaneous movement (when AP is actuated) from top to the bottom of core. BOC and EOC moments are considered including the situations when the most effective single control rod is stuck in upper position. In initial position all the banks except of Regulating bank 10 were in the upper position.

Table 4.17 shows the RCT value that is essentially lower than the allowable one in Table 4.1.

Table 4.14 describes the scheme of conservative evaluation of core subcriticality (scram margin) after scram actuation and reactor state transformation from nominal power to MCL. The effects and uncertainties involved in this scheme (vapor effect, absorbent irradiation, uncertainty of CRs worth calculation etc.) correspond to ones adopted in the West, particularly, in the US and France.

\footnotetext{
" Temperature drop in Fig.4.1 is the difference between output and input coolant temperatures for an assembly considered as a channel.

${ }^{\mathrm{b}}$ It should be reminded that the level numeration begins from the core bottom and the number of calculational levels in BIPR-7A was 10 .
} 


\section{RUSSIAN RESEARCH CENTER KURCHATOV INSTITUTE \\ Design Studies of " $100 \%$ Pu" MOX Lead Test Assembly (Report for FY99)}

\subsubsection{MOX Core}

3 MOX assemblies have been located in uranium reference core according to the principals mentioned in p.4.1.

The positions 8,88 and 150 for the first MOX loading (Fig.4.7) have been chosen because they possess self-powered detectors (see Fig.4.6). Other assemblies have been replaced to ensure a minimum value of $\mathrm{Kq}$ calculated by BIPR-7A. Besides, several fresh assemblies of "Ba" type (it is described in Fig.2.3) have been added to the first MOX loading. Reloading schemes for second and third cycles with 3 MOX LTAs are presented correspondingly in Figures 4.17 and 4.27.

The values of average assembly parameters calculated by the code BIPR-7A are presented for 3 successive fuel cycles in Figures 4.8-4.10 and Tables 4.7 (first cycle), Figures 4.18-4.20 and Tables 4.9 (second cycle), Figures 4.28-4.30 and Tables 4.11 (third cycle).

The attained power peaking factors obtained by pin-by-pin code PERMAK-A are presented in Table 4.13. The linear pin powers for BOC and EOC are presented correspondingly in Figures 4.11 and 4.12 (first cycle), Figures 4.21 and 4.22 (second cycle), Figures 4.31 and 4.32 (third cycle). Pin-by-pin power distributions in BOC and EOC both for the most powered assemblies and for MOX LTAs are presented in Figures 4.13-4.16 (first cycle), 4.23-4.26 (second cycle), 4.33-4.36 (third cycle).

Table $4.8,4.10$ and 4.12 show correspondingly the parameters values in zero power states for the first, the second and the third fuel MOX cycles calculated by the code BIPR-7A.

It is seen that MOX cores meet the safety requirements presented in Tables 4.14.4 for power peaking factors and reactivity coefficients.

Table $4.15 \mathrm{a}$ and $4.15 \mathrm{~b}$ show the CRs worth. It is seen that the conventional limiting value of $5500 \mathrm{pcm}$ (Table 4.3) is respected.

Table 4.16 shows core reactivity evolution in the process of AP actuation.

Table 4.17 shows the RCT values that are strongly lower than the conventional allowable value of $210^{\circ} \mathrm{C}$.

Table 4.14 describes the scheme of conservative evaluation of core subcriticality (scram margin).

It can be seen that the presence of 3 MOX LTAs does not influence $(\mathrm{RO})_{\mathrm{AP}}$ in clear manner. Its value is determined first of all by core loading pattern. It may be supposed that only significant value of MOX assemblies in core could lead to lowering of control rods worth because of strong absorbing capacity of MOX fuel. 
RUSSIAN RESEARCH CENTER KURCHATOV INSTITUTE

Design Studies of " $100 \%$ Pu" MOX Lead Test Assembly (Report for FY99)

\section{CONCLUSION}

LTA:

The report presents the results of design studies of full scale (" $100 \% \mathrm{Pu}$ ") MOX

- Parametric studies of multi-assemblies to define MOX LTA structure primarily to choose plutonium content in assembly zones that ensures reasonable power peaking factors and power generation equivalence in MOX and UOX assemblies.

- Parametric studies of "core fragments" in order to understand an influence of UOX environment (varying its properties distribution) on MOX assemblies optimal characteristics.

- Studies of VVER-1000 core characteristics with 3 MOX LTAs introduced for three successive fuel cycles.

The parametric studies have been executed by the code TVS-M that is at the final stage of licensing and it is to be used in the nearest future as a base instrument for VVER core calculations while using both uranium and MOX fuel.

For core investigation the fissile plutonium content composition $4.2 \% / 3.0 \% / 2.0 \%$ in MOX assembly has been chosen.

Parametric studies allow finding more or less acceptable plutonium grading in MOX assembly on the base of existing safety limitations. Final choice of a chosen MOX assembly structure must be confirmed in the process of MOX core calculations.

VVER-1000 core with boron burnable control rods has been chosen as a base for 3 MOX LTAs introduction.

Fuel loadings with 3 MOX LTAs have been optimized to ensure a minimum value of power peaking factor $\mathrm{Kq}$.

Evolution of main neutronics parameters during 3 successive cycles with MOX LTAs is presented. It is shown that MOX loaded cores meet the safety requirements preliminary adopted for MOX fuel concerning power peaking factors, reactivity coefficients and control rods worth. 
RUSSIAN RESEARCH CENTER KURCHATOV INSTITUTE Design Studies of "100\%Pu" MOX Lead Test Assembly (Report for FY99)

\section{REFERENCES}

1. Y.A. Styrin. Fuel Assembly and Core Model for Neutronics Calculations of VVER-1000. Draft.

Moscow, Kurchatov Institute 1998.

2. Y.A. Styrin, I.K.Levina. Design of Lead Test MOX Assemblies for Pilot Irradiation in VVER-1000 and Related Parametric Studies. Draft.

Moscow, Kurchatov Institute 1998.

3. S.A. Bichkov, A.P.Lazarenko, V.D.Sidorenko, Y.A. Styrin. Results of Parametric Design Studies of MOX Lead Test Assembly (Final Report).

Moscow, Kurchatov Institute 1998.

4. V.D.Sidorenko et al. Spectral Code TBC-M for calculation of Characteristics of Cells, Super-cells and Fuel Assemblies of VVER-Type Reactors. 5-th Symposium of the AER.

5. Neutronics Benchmarks for the Utilization of Mixed-Oxide Fuel: Joint U.S./Russian Progress Report for Fiscal Year 1997. Volume 3 - Calculations Performed in the Russian Federation. ORNL/TM-13603/V3.

6. Y.A. Styrin. Calculations of MOX LTA Performance in VVER-1000 Core. Moscow, Kurchatov Institute 1998.

7. In-core fuel management code package validation for WWERs. IAEATECDOC-847. November 1995.

8. Kaloinen E., Siltanen P., Terasvirta R. Two-group nodal calculations in hexagonal fuel assembly geometry. - In: Proc. of NFACRP Specialists' Meeting on Calculation of 3-D Rating Distributions in Operating Reactors. Paris, 1979.

9. Z.N. Chizhikova, A.G. Kalashnikov et al. Verification Calculation Results to Validate the Procedures and Codes for Pin-by-Pin Power Computation in VVER Type Reactors with MOX Fuel Loading. Fifth Technical Specialists Meeting. Water Reactors-1. Oak Ridge. November 11-13, 1998.

10. S.S.Alioshin, S.A. Bichkov, S.N.Bolshagin, A.P.Lazarenko, V.D.Sidorenko, Y.A. Styrin. Design Studies of «Island» Type MOX Lead Test Assembly. Moscow, Kurchatov Institute 1999. 
RUSSIAN RESEARCH CENTER KURCHATOV INSTITUTE

Design Studies of "100\%Pu" MOX Lead Test Assembly (Report for FY99)

Table 2.1. Composition of weapons grade plutonium

\begin{tabular}{|l|l|l|l|l|}
\hline Isotope / content (Wt. \%) \\
\hline $\mathrm{Pu}-238$ & $\mathrm{Pu}-239$ & $\mathrm{Pu}-240$ & $\mathrm{Pu}-241$ & $\mathrm{Pu}-242$ \\
\hline 0.0 & 93.0 & 6.0 & 1.0 & 0.0 \\
\hline
\end{tabular}


Table 2.2. Main Core Parameters

\begin{tabular}{|l|l|l|}
\hline Parameter & Units & Value \\
\hline Thermal Power & & \\
\hline Electrical Power & $\begin{array}{l}\text { MW } \\
\text { thermal }\end{array}$ & 3000 \\
\hline Number of Coolant Loops & MW & 1000 \\
\hline Number of Fuel Assemblies & & 4 \\
\hline Core Equivalent Diameter & & 163 \\
\hline Core Fuel Height & $\mathrm{m}$ & 3.164 \\
\hline Core Volume & $\mathrm{m}$ & 3.53 \\
\hline Core Power Density & $\mathrm{m}^{3}$ & 27.8 \\
\hline Control/ Shut off Rod Banks & $\mathrm{W} / \mathrm{cm}^{3}$ & 108 \\
\hline Position of Regulating Rod Bank & & $\mathbf{\%}$ \\
\hline Core Coolant Flow Rate & $\mathrm{m}^{3} / \mathrm{hr}$ & 80 \\
\hline Pressure at Core Inlet & $\mathrm{MPa}$ & 84000 \\
\hline Core Inlet Temperature & ${ }^{\circ} \mathrm{C}$ & 15.7 \\
\hline
\end{tabular}


RUSSIAN RESEARCH CENTER KURCHATOV INSTITUTE

Design Studies of " $100 \%$ Pu" MOX Lead Test Assembly (Report for FY99)

Table 2.3. Fuel Assembly Design Parameters

\begin{tabular}{|l|c|c|}
\hline Parameter & Units & Value \\
\hline Shape of Fuel Assembly & & Hexagonal \\
\hline Distance Across Assembly (between flats) & $\mathrm{cm}$ & 23.4 \\
\hline Distance Between Fuel Assembly Centres & $\mathrm{cm}$ & $\mathbf{2 3 . 6}$ \\
\hline Fuel Pin Lattice Pitch & $\mathrm{cm}$ & $\mathbf{1 . 2 7 5}$ \\
\hline Number of Fuel Pins in Fuel Assembly & & $\mathbf{3 1 2}$ \\
\hline $\begin{array}{l}\text { Number of Guide Tubes for Control Rods } \\
\text { Burnable Absorber Pins }\end{array}$ & & 18 \\
\hline Inner Diameter of Guide Thimbles & $\mathrm{cm}$ & $\mathbf{1 . 1}$ \\
\hline Thickness of Guide Thimbles & $\mathrm{cm}$ & $\mathbf{0 . 1}$ \\
\hline Material of Guide Thimbles & & Zirconium Alloy \\
\hline $\begin{array}{l}\text { Central Instrumentation Tube Inner } \\
\text { Diameter }\end{array}$ & $\mathrm{cm}$ & $\mathbf{1 . 1}$ \\
\hline Thickness of Central Instrumentation Tube & $\mathrm{cm}$ & Zirconium Alloy ${ }^{*}$ \\
\hline Material of Central Guide Tube & & 13 \\
\hline Number of Spacer Grids in Fuel Assembly & & Kirconium Alloy \\
\hline Material of Spacer Grids & & 0.55 \\
\hline Spacer Grid Weight (each) & & \\
\hline
\end{tabular}

Compositions Weight percent:

\begin{tabular}{|c|c|c|}
\hline $\mathbf{Z r}$ & $\mathbf{N b}$ & Hf \\
\hline 98.97 & 1.0 & 0.03 \\
\hline
\end{tabular}


RUSSLAN RESEARCH CENTER KURCHATOV INSTITUTE

Design Studies of "100\%Pu" MOX Lead Test Assembly (Report for FY99)

Table 2.4. Uranium Fuel Pin Design Parameters

\begin{tabular}{|l|l|l|}
\hline Parameter & Units & Value \\
\hline Inner Clad Diameter & & Advanced Core Design \\
\hline Clad Thickness & $\mathrm{cm}$ & 0.772 \\
\hline Clad Material & $\mathrm{cm}$ & 0.069 \\
\hline Clad Density & & Zirconium Alloy ${ }^{*}$ \\
\hline Fuel Pellet Diameter & $\mathrm{g} / \mathrm{cc}$ & 6.5153 \\
\hline Central Hole Diameter & $\mathrm{cm}$ & $\mathbf{0 . 7 5 5}$ \\
\hline Fuel Pellet Material & $\mathrm{cm}$ & 0.15 \\
\hline Height of Fuel Column & & L.E. UO2 \\
& $\mathrm{cm}$ & $\begin{array}{l}353 \text { (cold) } \\
355 \text { (hot) }\end{array}$ \\
\hline Mass of UO2 in Fuel Pin & & 1.575 \\
\hline
\end{tabular}

Compositions Weight percent:

$*$
\begin{tabular}{|l|l|l|}
\hline $\mathrm{Zr}$ & Nb & Hf \\
\hline 98.97 & 1.0 & 0.03 \\
\hline
\end{tabular}


RUSSIAN RESEARCH CENTER KURCHATOV INSTITUTE

Design Studies of “100\%Pu” MOX Lead Test Assembly (Report for FY99)

Table 2.5. MOX fuel Pin Design Parameters

\begin{tabular}{|l|c|c|}
\hline Parameter & Units & Value \\
\hline Inner Clad Diameter & cm & 0.772 \\
\hline Clad Thickness & $\mathrm{cm}$ & $\mathbf{0 . 0 6 9}$ \\
\hline Clad Material & & Zirconium Alloy* \\
\hline Clad Density & $\mathrm{g} / \mathrm{cc}$ & $\mathbf{6 . 5 1 5 3}$ \\
\hline Fuel Pellet Diameter & $\mathrm{cm}$ & $\mathbf{0 . 7 5 5}$ \\
\hline Central Hole Diameter & $\mathrm{cm}$ & 0.15 \\
\hline U-235 content in MOX fuel & $\%$ & 0.2 \\
\hline Fuel Pellet Material & & PuO2-UO2 \\
\hline Height of Fuel Column & $\mathrm{cm}$ & 353 (cold) \\
& & 355 (hot) \\
\hline Mass of MOX fuel in Fuel Pin & $\mathrm{kg}$ & 1.600 \\
\hline
\end{tabular}

Compositions Weight percent:

$*$
\begin{tabular}{|l|l|l|}
\hline $\mathrm{Zr}$ & Nb & Hf \\
\hline $\mathbf{9 8 . 9 7}$ & 1.0 & $\mathbf{0 . 0 3}$ \\
\hline
\end{tabular}


RUSSIAN RESEARCH CENTER KURCHATOV INSTITUTE

Design Studies of "100\%Pu" MOX Lead Test Assembly (Report for FY99)

Table 2.6. Discrete Burnable Poison Pin Design Parameters

\begin{tabular}{|c|c|c|c|}
\hline Parameter & Units & \multicolumn{2}{|c|}{ Value } \\
\hline Clad Inner Diameter & $\mathbf{c m}$ & \multicolumn{2}{|c|}{0.772} \\
\hline Clad Thickness & $\mathbf{c m}$ & \multicolumn{2}{|c|}{0.069} \\
\hline Clad Material & & \multicolumn{2}{|c|}{ Zirconium Alloy* } \\
\hline Clad Density & $\mathrm{g} / \mathrm{cc}$ & \multicolumn{2}{|c|}{6.5153} \\
\hline Absorber Diameter & $\mathrm{cm}$ & \multicolumn{2}{|c|}{0.758} \\
\hline Absorber Density & $\mathrm{g} / \mathrm{cc}$ & \multicolumn{2}{|c|}{2.945} \\
\hline Absorber Composition & & \multicolumn{2}{|c|}{ Boron g/ cc } \\
\hline & & 0.036 & 0.065 \\
\hline B10 & Wt $\%$ & 0.2279 & 0.4046 \\
\hline B11 & & 1.0153 & 1.8028 \\
\hline $\mathbf{A l}$ & & 91.7424 & 88.5951 \\
\hline $\mathrm{Fe}$ & & 0.1915 & 0.1850 \\
\hline $\mathbf{N i}$ & & 1.9153 & 1.8496 \\
\hline $\mathrm{Cr}$ & & 2.9923 & 5.3133 \\
\hline $\mathbf{Z r}$ & & 1.9153 & 1.8496 \\
\hline
\end{tabular}

Compositions Weight percent:

*

\begin{tabular}{|l|l|l|}
\hline $\mathrm{Zr}$ & $\mathrm{Nb}$ & Hf \\
\hline 98.97 & 1.0 & 0.03 \\
\hline
\end{tabular}


RUSSIAN RESEARCH CENTER KURCHATOV INSTITUTE

Design Studies of "100\%Pu" MOX Lead Test Assembly (Report for FY99)

Table 2.6a. Control Rod Design Parameters

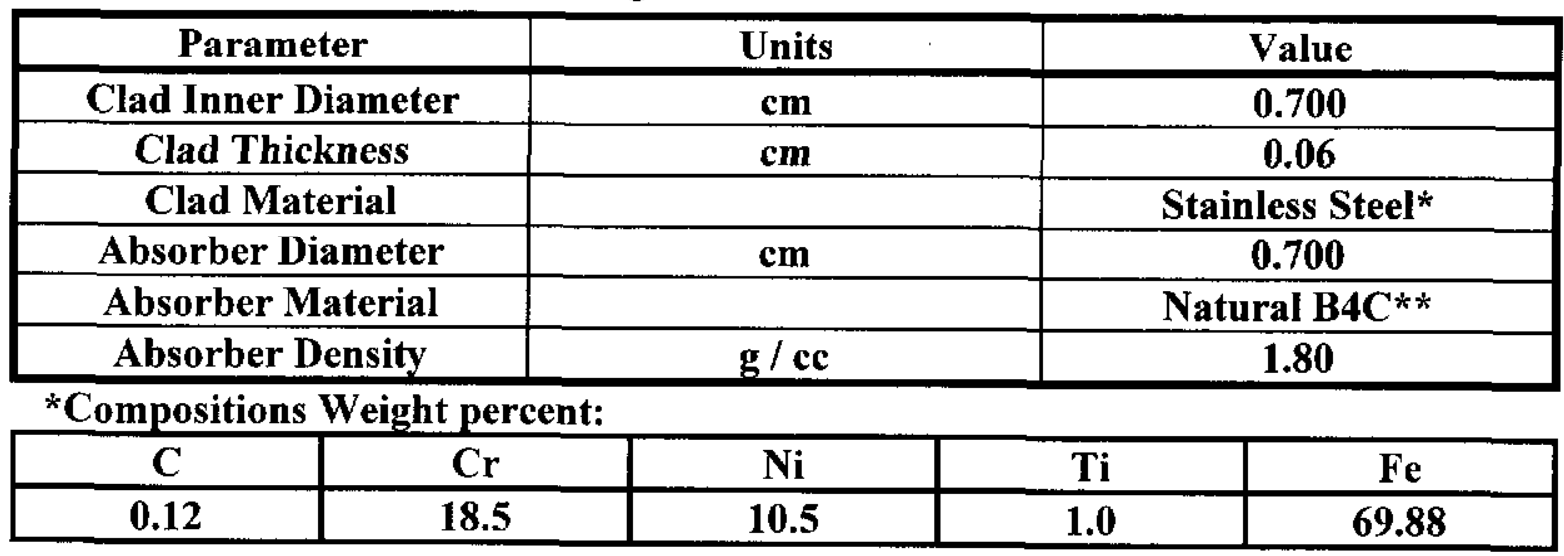

** Content of ${ }^{10} \mathrm{~B}$ is $19.8 \%$ atoms.

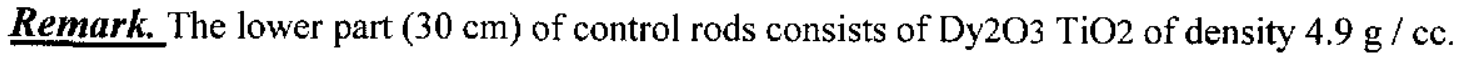


Table 2.7. Keff in Zero Power States

\begin{tabular}{|c|c|c|c|c|c|c|c|c|c|c|c|c|c|c|c|c|c|c|c|c|}
\hline \multirow[t]{2}{*}{$\begin{array}{l}\text { Irradiation } \\
\text { Point } \rightarrow \\
\end{array}$} & \multicolumn{4}{|c|}{0} & \multicolumn{4}{|c|}{$\begin{array}{c}\text { 10, } \\
\text { GWd/t }\end{array}$} & \multicolumn{4}{|c|}{$\begin{array}{c}20, \\
\text { GWd/t }\end{array}$} & \multicolumn{4}{|c|}{$\begin{array}{c}\text { 30, } \\
\text { GWd/t }\end{array}$} & \multicolumn{4}{|c|}{$\begin{array}{c}40 \\
\text { GWd/t }\end{array}$} \\
\hline & \multicolumn{2}{|c|}{$\begin{array}{l}\text { Tmod=Tfuel } \\
=\mathrm{T} \operatorname{con} \\
=20^{\circ} \mathrm{C}\end{array}$} & \multicolumn{2}{|c|}{$\begin{array}{l}\text { Tmod=Tfuel } \\
=\text { Tcon } \\
=280^{\circ} \mathrm{C}\end{array}$} & \multicolumn{2}{|c|}{$\begin{array}{l}\text { Tmod=' Tfuel } \\
=\text { Tcon } \\
=20^{\circ} \mathrm{C}\end{array}$} & \multicolumn{2}{|c|}{ 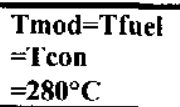 } & \multicolumn{2}{|c|}{$\begin{array}{l}\text { Tmod=Tfuel } \\
=\mathrm{Tcon} \\
=20^{\circ} \mathrm{C}\end{array}$} & \multicolumn{2}{|c|}{$\begin{array}{l}\text { Tmod=Tfuel } \\
=T c o n \\
=280^{\circ} \mathrm{C}\end{array}$} & \multicolumn{2}{|c|}{$\begin{array}{l}\text { Tmod=Tfuel } \\
=\text { Tcon } \\
=20^{\circ} \mathrm{C}\end{array}$} & \multicolumn{2}{|c|}{$\begin{array}{l}\text { Tmod }=\text { Tfuel } \\
=\text { Tcon } \\
=280^{\circ} \mathrm{C}\end{array}$} & \multicolumn{2}{|c|}{$\begin{array}{l}\text { Tmod=Tfuel } \\
=\text { Tcon } \\
=20^{\circ} \mathrm{C}\end{array}$} & \multicolumn{2}{|c|}{$\begin{array}{l}\text { Tmod=Tfuel } \\
=\text { Tcon } \\
=280^{\circ} \mathrm{C}\end{array}$} \\
\hline $\begin{array}{l}\text { Pu/ } / \\
\text { Content, \% } \\
\downarrow \\
\end{array}$ & 0 & 孞 & 0 & 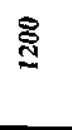 & 0 & ఫ్త్ & $=$ & ঙ્ఝ & 0 & 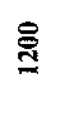 & 0 & 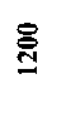 & $=$ & ఫ్త్ & 0 & 0 & ঙ્త్ & 0 & 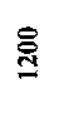 & 旁 \\
\hline $\begin{array}{l}\text { U: } \\
\text { 3.7/3.3 no BPR }\end{array}$ & 㳯 & 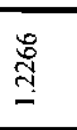 & $\begin{array}{l}10 \\
2 \\
2\end{array}$ & 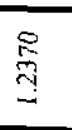 & $\overrightarrow{\check{c}}$ & $\stackrel{\text { }}{8}$ & @ָ & $\stackrel{\infty}{\stackrel{\Xi}{\Xi}}$ & $\stackrel{\infty}{=}$ & $\stackrel{\stackrel{m}{5}}{\underbrace{}_{i}}$ & 气 & 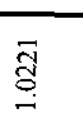 & $\stackrel{0}{\circ}$ & $\frac{+}{\hat{\sigma}}$ & 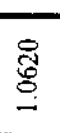 & 总 & $\stackrel{8}{2}$ & $\begin{array}{l}\tilde{B} \\
\infty \\
\infty\end{array}$ & $\begin{array}{l}9 \\
8 \\
8 \\
0\end{array}$ & $\begin{array}{l}\text { NO } \\
\infty \\
\infty \\
0\end{array}$ \\
\hline $\begin{array}{l}\mathrm{U}: \\
\text { 3.7/3.3 with BPR }\end{array}$ & 응 & 京 & $\stackrel{m}{m}$ & 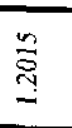 & 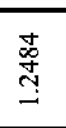 & $\begin{array}{l}\infty \\
\$ \\
0 \\
-\end{array}$ & 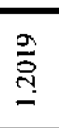 & $\stackrel{\Xi}{\infty}$ & \begin{tabular}{l}
$\infty$ \\
$\substack{\infty \\
\hdashline}$ \\
$=$
\end{tabular} & 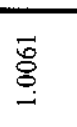 & 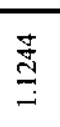 & $\stackrel{m}{\stackrel{0}{0}}$ & $\stackrel{6}{8}$ & 戀 & $\stackrel{r}{i}$ & 䓫 & $\stackrel{n}{2}$ & $\begin{array}{l}8 \\
8 \\
\infty \\
0 \\
0\end{array}$ & $\begin{array}{l}\mathscr{\hat { \infty }} \\
\stackrel{8}{\circ}\end{array}$ & \begin{tabular}{l}
\multirow{2}{*}{} \\
$\infty$ \\
0 \\
0
\end{tabular} \\
\hline $\begin{array}{l}\text { PU: } \\
4.4 / 3.0 / 2.4\end{array}$ & 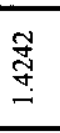 & $\underset{\overparen{g}}{\overparen{g}}$ & $\underset{\substack{n \\
n}}{2}$ & $\stackrel{y}{\stackrel{y}{y}}$ & 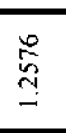 & \& & 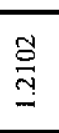 & $\stackrel{9}{2}$ & $\begin{array}{l}9 \\
8 \\
0 \\
=\end{array}$ & $\stackrel{0}{0}$ & $\stackrel{\text { 吕 }}{\stackrel{\Xi}{=}}$ & $\stackrel{\infty}{\underset{\infty}{0}}$ & $\begin{array}{l}\mathscr{0} \\
\stackrel{8}{\circ} \\
\stackrel{0}{\circ}\end{array}$ & $\frac{\mathbb{J}}{\vec{J}}$ & $\stackrel{0}{\stackrel{0}{\sigma}}$ & $\frac{\alpha}{\alpha}$ & $\stackrel{ \pm}{\stackrel{5}{0}}$ & $\begin{array}{c}\text { y } \\
\text { D } \\
0 \\
0\end{array}$ & $\begin{array}{l}\infty \\
\infty \\
\infty \\
0 \\
0\end{array}$ & $\begin{array}{l}\mathcal{N} \\
\infty \\
\infty \\
0\end{array}$ \\
\hline $\begin{array}{l}\mathrm{PU}: \\
4.4 / 3.0 / 2.0\end{array}$ & $\stackrel{\Re}{\underset{\nabla}{\sigma}}$ & స్ & 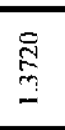 & $\stackrel{\vec{m}}{\stackrel{m}{\sim}}$ & $\begin{array}{l}3 \\
\stackrel{3}{N} \\
\end{array}$ & $\stackrel{\mathscr{S}}{g}$ & 粱 & $\begin{array}{l}r_{2} \\
8 \\
8 \\
0\end{array}$ & $\underset{\Xi}{\stackrel{\Xi}{0}}$ & $\stackrel{9}{\stackrel{9}{0}}$ & $\begin{array}{l} \pm \\
\stackrel{\Xi}{\Xi}\end{array}$ & $\stackrel{\Xi}{\sigma}$ & $\begin{array}{l}\mathscr{\infty} \\
\stackrel{\infty}{\infty} \\
\stackrel{\infty}{0}\end{array}$ & 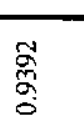 & $\begin{array}{l}\infty \\
\stackrel{\infty}{\sigma} \\
\stackrel{0}{0}\end{array}$ & $\stackrel{\stackrel{0}{*}}{\stackrel{2}{*}}$ & $\stackrel{5}{0}$ & $\underset{\substack{\overparen{N} \\
\infty \\
0}}{ }$ & $\begin{array}{l}\text { o } \\
\text { 葛 } \\
0 \\
0\end{array}$ & $\begin{array}{l}\approx \\
\infty \\
\infty \\
0 \\
0\end{array}$ \\
\hline $\begin{array}{l}\text { PU: } \\
\text { 4.4/3.2/2.0 }\end{array}$ & $\begin{array}{l}\stackrel{\Xi}{J} \\
\text { J }\end{array}$ & 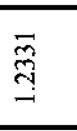 & 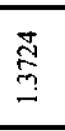 & $\begin{array}{l}\vec{m} \\
\vec{y}\end{array}$ & 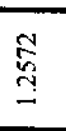 & $\stackrel{\infty}{\stackrel{2}{g}}$ & $\underset{\substack{8 \\
\hdashline}}{9}$ & $\stackrel{\mathbb{2}}{\mathrm{S}}$ & $\stackrel{2}{0}$ & $\stackrel{\square}{\stackrel{7}{0}}$ & $\stackrel{\text { 竞 }}{=}$ & $\stackrel{\infty}{\Xi}$ & $\stackrel{\overline{\mathscr{\alpha}}}{\stackrel{-}{-}}$ & 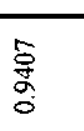 & 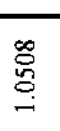 & 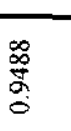 & $\stackrel{8}{0}$ & $\begin{array}{l}\infty \\
\stackrel{\infty}{\infty} \\
\stackrel{\infty}{0}\end{array}$ & 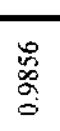 & $\begin{array}{l}\infty \\
\infty \\
\infty \\
\infty \\
0 \\
0\end{array}$ \\
\hline $\begin{array}{l}\text { PU: } \\
4.2 / 3.0 / 2.0\end{array}$ & $\begin{array}{l}\overline{\text { đิ }} \\
\text { ป. }\end{array}$ & $\stackrel{n}{\stackrel{n}{-}}$ & $\stackrel{n}{2}$ & $\stackrel{\sim}{\cong}$ & $\begin{array}{l}\mathscr{D} \\
\stackrel{2}{\Im} \\
\end{array}$ & 茴 & 芯 & $\stackrel{ }{g}$ & $\begin{array}{l}0 \\
0 \\
=\end{array}$ & $\stackrel{\circ}{g}$ & $\begin{array}{l}\Xi \\
\Xi\end{array}$ & $\stackrel{\infty}{\stackrel{\infty}{0}}$ & 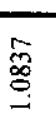 & 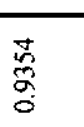 & $\stackrel{5}{\text { 号 }}$ & $\begin{array}{l}\stackrel{8}{\sharp} \\
\stackrel{+}{0} \\
\stackrel{0}{0}\end{array}$ & $\stackrel{\Xi}{\Xi}$ & $\begin{array}{l}0 \\
\hat{\infty} \\
0 \\
0 \\
0\end{array}$ & $\begin{array}{l}\stackrel{\leftrightarrow}{\circ} \\
\stackrel{\circ}{\circ} \\
\stackrel{0}{0}\end{array}$ & $\begin{array}{l}\text { đ్ } \\
\infty \\
\infty \\
0\end{array}$ \\
\hline
\end{tabular}


Table 2.8. Parameters Evolution in the Process of Fuel Irradiation. Reference Uranium Assemblage. No BPR

\begin{tabular}{|c|c|c|c|c|c|c|c|c|c|c|c|c|c|c|c|c|c|c|c|c|c|}
\hline $\begin{array}{c}\text { Irradiation } \\
\text { Point } \rightarrow\end{array}$ & \multicolumn{21}{|c|}{$\begin{array}{c}\text { Burnup, } \\
\text { GWd/t }\end{array}$} \\
\hline $\begin{array}{c}\text { Parameters } \\
\downarrow\end{array}$ & $\circ$ & N & $\nabla$ & 0 & $\infty$ & $\varrho$ & $\simeq$ & \pm & $\cong$ & $\stackrel{\infty}{2}$ & సิ & $\pi$ & $\overrightarrow{4}$ & $\stackrel{\sim}{*}$ & $\stackrel{\infty}{\sim}$ & p & లె & ले & i & $\stackrel{\infty}{\infty}$ & F \\
\hline Keff & 总 & $\stackrel{\infty}{\stackrel{0}{\leftrightarrows}}$ & $\stackrel{5}{9}$ & $\stackrel{\infty}{:}$ & $\stackrel{8}{\stackrel{8}{h}}$ & $\stackrel{\infty}{\stackrel{\infty}{m}}$ & $\stackrel{+}{\Xi}$ & $\stackrel{\infty}{=}$ & 产 & 䒿 & $\stackrel{8}{8}$ & $\stackrel{?}{\stackrel{0}{\leftrightarrow}}$ & $\stackrel{a}{\overparen{a}}$ & 蔦 & ă & 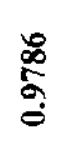 & 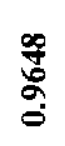 & $\frac{m}{80}$ & 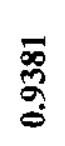 & $\begin{array}{l}\text { क्ष } \\
\text { o }\end{array}$ & $\frac{0}{a}$ \\
\hline Ko & 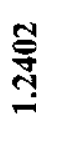 & 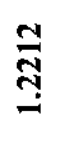 & ঙั๋ & $\stackrel{\text { : }}{=}$ & $\stackrel{\infty}{0}$ & $\stackrel{n}{\Xi}$ & $\stackrel{0}{\underset{3}{*}}$ & $\stackrel{\approx}{ٍ}$ & $\begin{array}{l}\overline{\times} \\
\stackrel{0}{-}\end{array}$ & $\stackrel{n}{5}$ & 兽 & $\stackrel{\circ}{\stackrel{\circ}{\leftrightarrow}}$ & 号 & 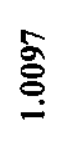 & 鸟 & $\begin{array}{l}\text { 今े } \\
\text { oे } \\
\text { o }\end{array}$ & 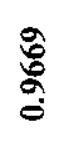 & 宽 & 㝘 & हू. & $\frac{10}{9}$ \\
\hline Kkmax-CS & 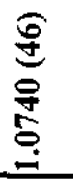 & 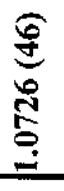 & 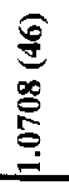 & 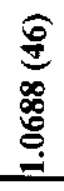 & 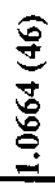 & 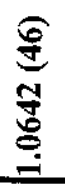 & $\begin{array}{l}\widehat{0} \\
\stackrel{0}{0} \\
\stackrel{0}{\circ} \\
\end{array}$ & 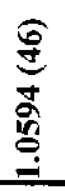 & 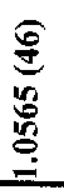 & 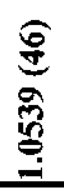 & 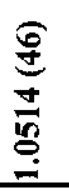 & 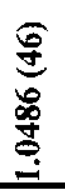 & $\begin{array}{l}0 \\
\stackrel{0}{0} \\
8 \\
\stackrel{8}{0} \\
\stackrel{9}{+}\end{array}$ & $\frac{\sigma}{\stackrel{6}{5}}$ & $\begin{array}{l}0 \\
\stackrel{0}{+} \\
5 \\
\stackrel{+}{+} \\
\end{array}$ & 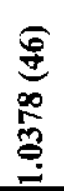 & $\begin{array}{l}0 \\
\stackrel{0}{0} \\
0 \\
0 \\
0\end{array}$ & 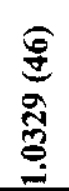 & 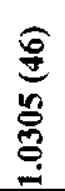 & 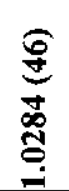 & 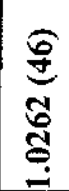 \\
\hline ßeff & 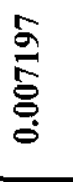 & 高 & $\begin{array}{l}0 \\
0\end{array}$ & 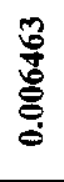 & 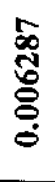 & & 总 & $\begin{array}{l}\stackrel{c}{0} \\
0 \\
\stackrel{0}{0} \\
\stackrel{0}{0}\end{array}$ & 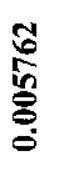 & 递 & 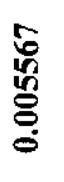 & 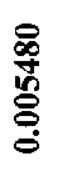 & 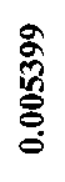 & 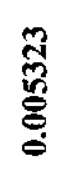 & 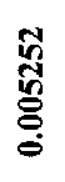 & 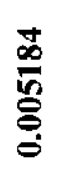 & ¿্ড & 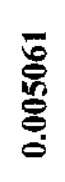 & 密 & 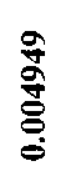 & 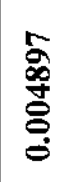 \\
\hline
\end{tabular}


Table 2.9. Parameters Evolution in the Process of Fuel Irradiation. Reference Uranium Assemblage with Boron
BPRs BPRs

\begin{tabular}{|c|c|c|c|c|c|c|c|c|c|c|c|c|c|c|c|c|c|c|c|c|c|}
\hline $\begin{array}{c}\text { Irradiation } \\
\text { Point } \rightarrow\end{array}$ & \multicolumn{21}{|c|}{$\begin{array}{l}\text { Burnup, } \\
\text { GWd/t }\end{array}$} \\
\hline $\begin{array}{c}\text { Parameters } \\
\downarrow\end{array}$ & $\theta$ & $N$ & T & $\bullet$ & $\infty$ & 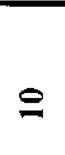 & $\simeq$ & \pm & $\underline{0}$ & $\stackrel{\infty}{=}$ & సิ & $\approx$ & $\bar{N}$ & : & $\stackrel{\infty}{i}$ & 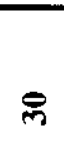 & లె & 芦 & i & $\stackrel{m}{\infty}$ & F \\
\hline Keff & 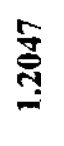 & $\stackrel{\infty}{\infty}$ & $\stackrel{2}{\Xi}$ & 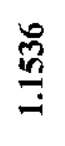 & $\stackrel{\square}{\stackrel{5}{2}}$ & $\underset{ }{g}$ & $\stackrel{\mathrm{J}}{\Xi}$ & 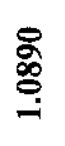 & Iี & 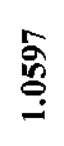 & 产 & $\stackrel{9}{\overparen{3}}$ & $\stackrel{5}{9}$ & 商 & $\begin{array}{l}\text { \% } \\
\text { \% } \\
0 \\
0\end{array}$ & s: & స్ర్ర & $\begin{array}{l}\text { gे } \\
\text { के } \\
0\end{array}$ & 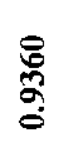 & ڤ̆ & $\underset{\sigma}{\sigma}$ \\
\hline Ko & $\stackrel{2}{3}$ & $\stackrel{\mathscr{D}}{\stackrel{g}{g}}$ & $\stackrel{\text { ڤે }}{:}$ & 옹 & 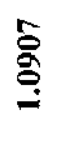 & $\stackrel{\text { : }}{\stackrel{乛}{\circ}}$ & 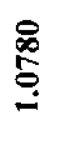 & $\stackrel{9}{9}$ & 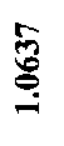 & 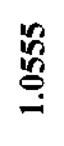 & 苍 & $\stackrel{\text { }}{\stackrel{8}{g}}$ & 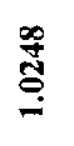 & $\stackrel{\text { m. }}{\longrightarrow}$ & $\stackrel{5}{5}$ & $\begin{array}{l}\bar{\infty} \\
\stackrel{\infty}{\circ} \\
\stackrel{0}{0}\end{array}$ & 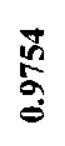 & $\begin{array}{l}\text { :ूँ } \\
\text { : }\end{array}$ & 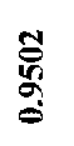 & 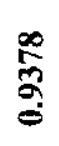 & $\stackrel{5}{5}$ \\
\hline Kkmax-CS & 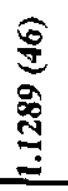 & $\begin{array}{l}\underset{9}{9} \\
\stackrel{0}{3} \\
\stackrel{3}{=} \\
\end{array}$ & 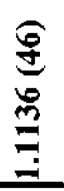 & 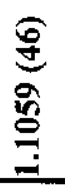 & $\begin{array}{l}\underset{0}{0} \\
\stackrel{0}{0} \\
\stackrel{0}{9}\end{array}$ & 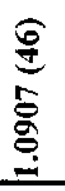 & 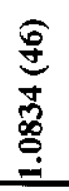 & $\begin{array}{l}0 \\
0 \\
8 \\
8 \\
0 \\
\end{array}$ & 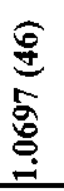 & 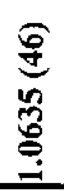 & 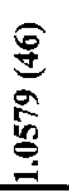 & 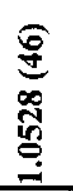 & 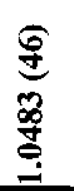 & 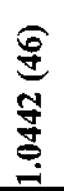 & 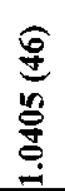 & 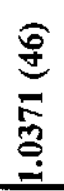 & 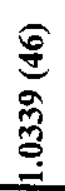 & 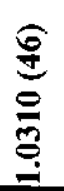 & 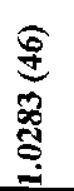 & 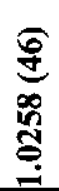 & 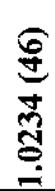 \\
\hline$\beta$ eff & 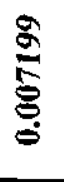 & 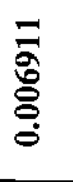 & 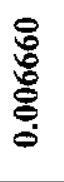 & $\begin{array}{l}\overline{\mathbf{n}} \\
\stackrel{+}{0} \\
\stackrel{0}{0}\end{array}$ & 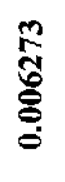 & 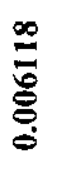 & 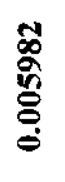 & 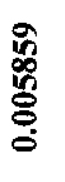 & 恿 & 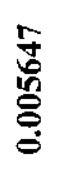 & 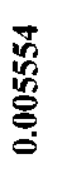 & 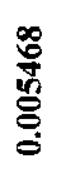 & 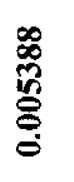 & 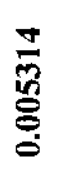 & 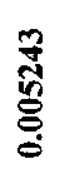 & 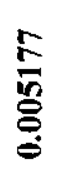 & 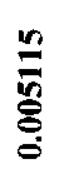 & 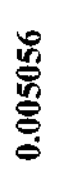 & 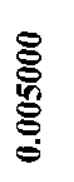 & 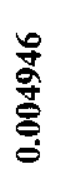 & 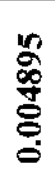 \\
\hline
\end{tabular}


Table 2.10. Parameters Evolution in the Process of Fuel Irradiation. MOX LTA 4.4/3.0/2.4

\begin{tabular}{|c|c|c|c|c|c|c|c|c|c|c|c|c|c|c|c|c|c|c|c|c|c|}
\hline $\begin{array}{c}\text { Irradiation } \\
\text { Point } \rightarrow\end{array}$ & \multicolumn{21}{|c|}{$\begin{array}{c}\text { Burnup, } \\
\text { GWd/t }\end{array}$} \\
\hline $\begin{array}{c}\text { Parameters } \\
\downarrow\end{array}$ & 0 & $N$ & + & 0 & $\infty$ & 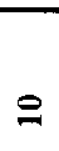 & $\cong$ & \pm & 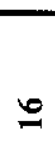 & $\stackrel{\infty}{=}$ & $\widetilde{\text { ก }}$ & $\approx$ & $\vec{N}$ & $\stackrel{2}{*}$ & $\stackrel{\sim}{\sim}$ & ్ㅛ & ले & "ా & $\ddot{n}$ & $\underset{m}{\infty}$ & \& \\
\hline Keff & $\stackrel{m}{\dddot{m}}$ & $\underset{\Xi}{\stackrel{\Xi}{\Xi}}$ & $\frac{\mathscr{O}}{\stackrel{\infty}{=}}$ & 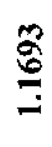 & $\stackrel{5}{2}$ & 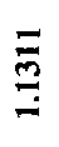 & $\stackrel{m}{=}$ & ڤั̊̆ & 突 & 昌 & $\stackrel{\infty}{\stackrel{\infty}{5}}$ & $\stackrel{\infty}{\infty}$ & $\stackrel{2}{a}$ & 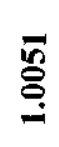 & $\stackrel{m}{\sigma}$ & $\stackrel{\frac{R}{S}}{\hat{S}}$ & :ّ̊ & $\stackrel{9}{\Omega}$ & 志 & 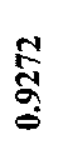 & 悹 \\
\hline Ko & 웜 & $\stackrel{尺}{\stackrel{2}{ }}$ & $\Xi$ & $\stackrel{\infty}{3}$ & $\stackrel{\mathscr{Y}}{\longleftarrow}$ & $\frac{\infty}{2}$ & $\stackrel{?}{\Xi}$ & $\stackrel{5}{\mathrm{~g}}$ & $\stackrel{\infty}{\infty}$ & : & $\stackrel{\infty}{g}$ & $\stackrel{2}{8}$ & $\stackrel{5}{\mathscr{S}}$ & $\stackrel{+}{0}$ & $\frac{n}{2}$ & $\begin{array}{l}\stackrel{9}{+} \\
\text { o. } \\
\text { ᄋ }\end{array}$ & 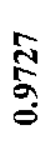 & 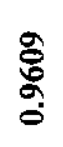 & $\frac{n}{\alpha}$ & 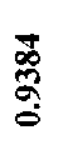 & $\frac{2}{5}$ \\
\hline Kkmax-CS & $\stackrel{\infty}{\stackrel{\circ}{\rightleftarrows}}$ & $\stackrel{\text { 总 }}{=}$ & $\stackrel{8}{g}$ & 岕 & $\stackrel{\infty}{\infty}$ & $\stackrel{0}{\mathscr{0}}$ & $\stackrel{\infty}{5}$ & $\stackrel{5}{5}$ & $\stackrel{n}{g}$ & $\begin{array}{l}\stackrel{0}{\circ} \\
\stackrel{5}{6}\end{array}$ & 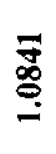 & $\stackrel{\infty}{\stackrel{\infty}{\circ}}$ & s. & 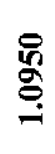 & 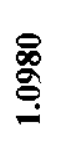 & $\stackrel{8}{\Xi}$ & 옹 & $\stackrel{g}{g}$ & $\mathscr{8}$ & $\stackrel{9}{5}$ & $\cong$ \\
\hline
\end{tabular}


Table 2.11. Parameters Evolution in the Process of Fuel Irradiation. MOX LTA 4.4/3.0/2.0

\begin{tabular}{|c|c|c|c|c|c|c|c|c|c|c|c|c|c|c|c|c|c|c|c|c|c|}
\hline $\begin{array}{c}\text { Irradiation } \\
\text { Point } \rightarrow\end{array}$ & \multicolumn{21}{|c|}{$\begin{array}{c}\text { Burnup, } \\
\text { GWd/t }\end{array}$} \\
\hline $\begin{array}{c}\text { Parameters } \\
\downarrow\end{array}$ & 0 & $N$ & + & 0 & $\infty$ & $\varrho$ & $\simeq$ & $\Xi$ & $\dddot{0}$ & $\stackrel{\infty}{\infty}$ & ते & 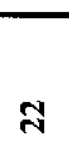 & $\vec{N}$ & i̊ & $\stackrel{\infty}{\sim}$ & ల్ల & లే & $\bar{m}$ & లొ & $\infty$ & $\mathscr{F}$ \\
\hline Keff & 冚 & ড్ & $\begin{array}{l}\infty \\
\stackrel{\infty}{\infty} \\
=\end{array}$ & : & 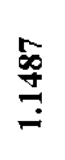 & 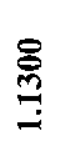 & $\stackrel{\bar{\Xi}}{\leftrightarrows}$ & 范 & 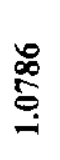 & 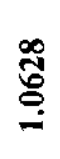 & 蒂 & 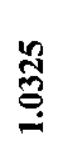 & $\stackrel{\infty}{\stackrel{\infty}{\leftrightarrow}}$ & 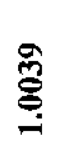 & 亏ू్ & \begin{tabular}{l}
0 \\
\multirow{2}{0}{} \\
2 \\
0
\end{tabular} & 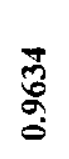 & 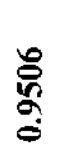 & $\begin{array}{l}\bar{\infty} \\
\text { o. } \\
0 \\
0\end{array}$ & 参 & $\stackrel{8}{\frac{8}{a}}$ \\
\hline Ko & 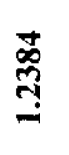 & 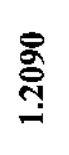 & $\stackrel{8}{\stackrel{\infty}{\leftrightarrows}}$ & 웅 & $\stackrel{⿱}{ \pm}$ & $\stackrel{8}{ت}$ & $\stackrel{\infty}{\stackrel{\infty}{g}}$ & $\stackrel{a}{\stackrel{a}{a}}$ & 菅 & 莺 & 晏 & 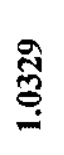 & $\stackrel{2}{9}$ & ఫ్ర & 蒙 & $\underset{\bar{\alpha}}{\stackrel{\bar{\alpha}}{\circ}}$ & ĭ & or & $\stackrel{\bar{\sigma}}{\alpha}$ & 带 & 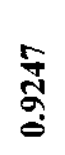 \\
\hline Kkmax-CS & 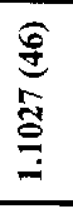 & $\begin{array}{l}\underset{0}{0} \\
0 \\
0 \\
\underline{0}\end{array}$ & 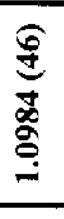 & 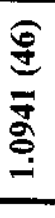 & 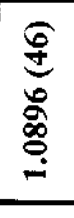 & $\begin{array}{l}0 \\
\stackrel{0}{0} \\
\stackrel{0}{0} \\
\stackrel{0}{0}\end{array}$ & 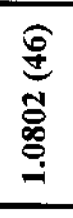 & 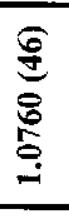 & 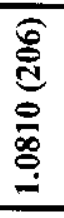 & 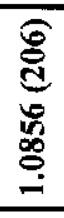 & 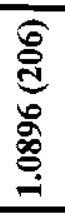 & 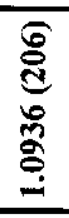 & 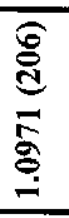 & 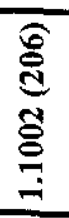 & 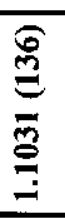 & 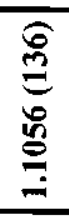 & 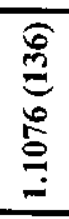 & 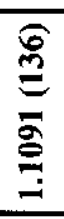 & $\begin{array}{l}\widehat{\widehat{O}} \\
\stackrel{d}{0} \\
0 \\
0 \\
0\end{array}$ & 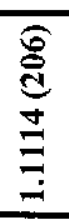 & 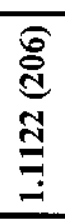 \\
\hline Beff & 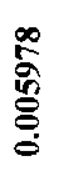 & 薃 & 兽 & 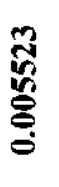 & $\stackrel{\infty}{:}$ & 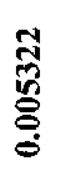 & 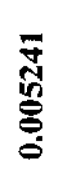 & 릉 & 容 & 兽 & 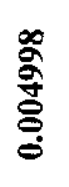 & 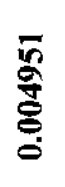 & 兽 & 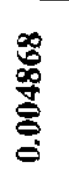 & 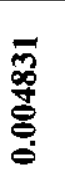 & 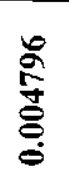 & 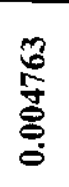 & 柋 & 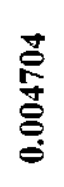 & 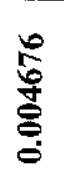 & 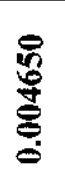 \\
\hline
\end{tabular}


Table 2.12. Parameters Evolution in the Process of Fuel Irradiation. MOX LTA 4.4/3.2/2.0

\begin{tabular}{|c|c|c|c|c|c|c|c|c|c|c|c|c|c|c|c|c|c|c|c|c|c|}
\hline $\begin{array}{c}\text { Irradiation } \\
\text { Point } \rightarrow\end{array}$ & \multicolumn{21}{|c|}{$\begin{array}{c}\text { Burnup, } \\
\text { GWd/t }\end{array}$} \\
\hline $\begin{array}{c}\text { Parameters } \\
\downarrow\end{array}$ & 0 & $N$ & + & 6 & $\infty$ & $\varrho$ & $\simeq$ & \pm & 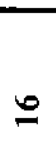 & $\stackrel{\infty}{=}$ & సิ & $\tilde{A}$ & I & $\stackrel{i}{i}$ & $\stackrel{\sim}{\sim}$ & p్ & లె & 吾 & 吕 & $\stackrel{\infty}{\infty}$ & $\mathscr{F}$ \\
\hline Keff & $\overline{\overparen{3}}$ & 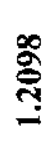 & $\stackrel{2}{\dddot{\infty}}$ & 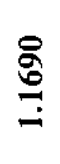 & 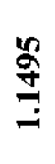 & $\stackrel{\text { : }}{=}$ & $\stackrel{0}{=}$ & 产 & 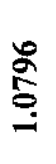 & $\stackrel{\infty}{\stackrel{6}{\Xi}}$ & $\stackrel{+}{\stackrel{+0}{+\infty}}$ & 䔡 & $\stackrel{0}{\square}$ & 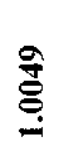 & $\bar{\sigma}$ & 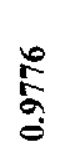 & $\begin{array}{l}\text { : } \\
\text { : } \\
0 \\
0\end{array}$ & s. & 㺃 & ڤั̆ & $\frac{\sqrt{n}}{3}$ \\
\hline Ko & ঙ্ড & $\underset{\Xi}{\exists}$ & 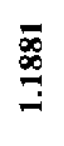 & $\stackrel{?}{6}$ & 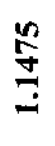 & 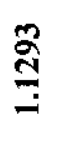 & $\Xi$ & ô & 唐 & 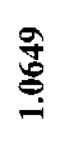 & 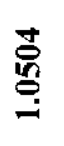 & 芯 & ঙ્ત્ & $\stackrel{5}{0}$ & \&े & $\begin{array}{l}\stackrel{0}{0} \\
\stackrel{0}{0} \\
\stackrel{0}{0}\end{array}$ & 咚 & $\begin{array}{l}\text { :े } \\
\text { के }\end{array}$ & $\frac{4}{20}$ & $\begin{array}{l}\text { 足 } \\
\text { 总 } \\
0\end{array}$ & 站 \\
\hline Kkmax-CS & 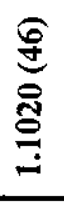 & 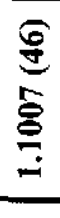 & 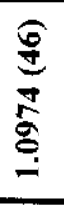 & 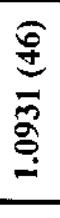 & 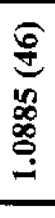 & 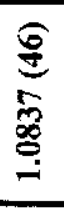 & 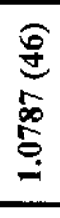 & 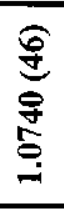 & 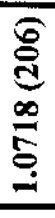 & $\begin{array}{l}6 \\
\stackrel{0}{0} \\
0 \\
0 \\
0 \\
\end{array}$ & 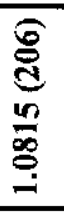 & $\begin{array}{l}\widehat{O} \\
\stackrel{0}{0} \\
6 \\
0 \\
0 \\
0\end{array}$ & 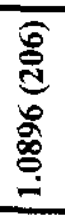 & 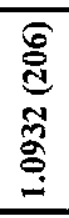 & 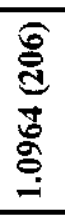 & 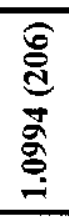 & 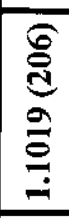 & 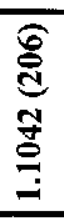 & 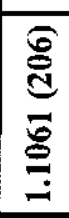 & 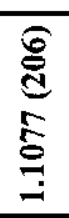 & 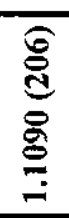 \\
\hline ßeff & 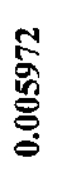 & $\begin{array}{l}\infty \\
\text { : } \\
\text { î̀ } \\
\text { : }\end{array}$ & 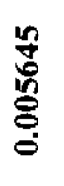 & $\begin{array}{l}\infty \\
\stackrel{\infty}{0} \\
\stackrel{0}{0} \\
0\end{array}$ & 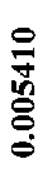 & 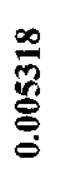 & 贷 & $\frac{8}{0}$ & $\frac{\check{c}}{80}$ & $\begin{array}{l}\text { 웅 } \\
\text { ᄋ̆ }\end{array}$ & : & 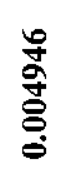 & 哀 & 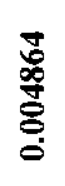 & 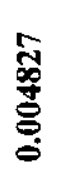 & 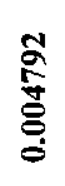 & 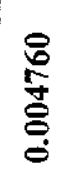 & 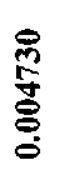 & 产 & 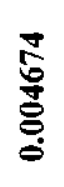 & 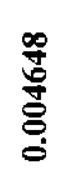 \\
\hline
\end{tabular}


Table 2.13. Parameters Evolution in the Process of Fuel Irradiation. MOX LTA 4.2/3.0/2.0

\begin{tabular}{|c|c|c|c|c|c|c|c|c|c|c|c|c|c|c|c|c|c|c|c|c|c|}
\hline $\begin{array}{c}\text { Irradiation } \\
\text { Point } \rightarrow\end{array}$ & \multicolumn{21}{|c|}{$\begin{array}{c}\text { Burnup, } \\
\text { GWd/t }\end{array}$} \\
\hline $\begin{array}{c}\text { Parameters } \\
\downarrow\end{array}$ & 0 & $n$ & + & 6 & $\infty$ & 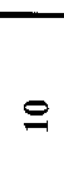 & $\simeq$ & \pm & 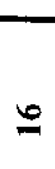 & $\stackrel{\infty}{\sim}$ & స్ & $\pi$ & $\overline{4}$ & $\stackrel{4}{i}$ & జి & ले & ल & 崩 & $\underbrace{\infty}$ & $\stackrel{\infty}{\infty}$ & F \\
\hline Keff & 突 & $\stackrel{\infty}{\stackrel{\infty}{\leftrightarrows}}$ & $\stackrel{乛}{\stackrel{\infty}{Z}}$ & : & $\stackrel{8}{3}$ & 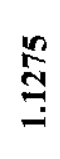 & $\stackrel{+}{g}$ & 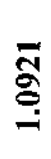 & 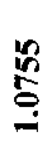 & 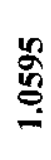 & $\stackrel{\text { f }}{\stackrel{g}{g}}$ & 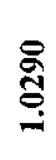 & $\stackrel{7}{g}$ & 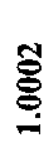 & $\begin{array}{l}\stackrel{8}{8} \\
\stackrel{8}{0} \\
\stackrel{0}{0}\end{array}$ & 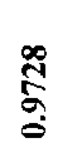 & 范 & 产 & 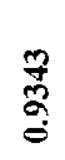 & ส্ู & $\frac{3}{2}$ \\
\hline Ko & 范 & ఝั้ & $\stackrel{\infty}{\stackrel{\infty}{=}}$ & $\stackrel{0}{3}$ & $\stackrel{8}{\frac{8}{2}}$ & $\stackrel{n}{3}$ & $\stackrel{\Xi}{=}$ & 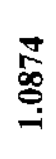 & $\stackrel{+}{\stackrel{5}{g}}$ & : & $\stackrel{2}{g}$ & 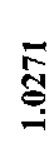 & $\stackrel{\stackrel{m}{g}}{g}$ & 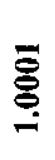 & $\begin{array}{l}\text { No } \\
\text { o } \\
\stackrel{0}{0}\end{array}$ & $\begin{array}{l}\frac{\infty}{0} \\
\text { ca } \\
0\end{array}$ & 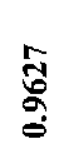 & $\bar{g}$ & 㐫 & 兽 & $\frac{\infty}{0}$ \\
\hline Kkmax-CS & $\begin{array}{l}\underset{9}{0} \\
\text { 旁 } \\
=\end{array}$ & 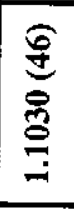 & 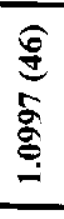 & 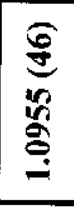 & 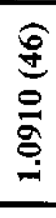 & 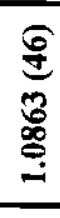 & 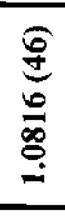 & 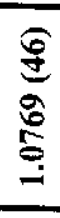 & 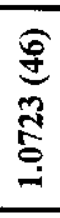 & 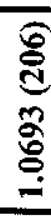 & 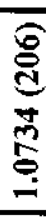 & 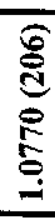 & 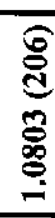 & 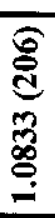 & 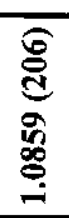 & 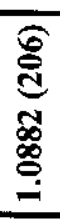 & 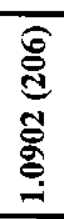 & 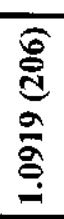 & $\begin{array}{l}\hat{\sigma} \\
\text { d. } \\
0 \\
0 \\
0\end{array}$ & 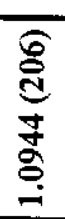 & 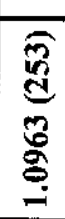 \\
\hline$\beta$ eff & 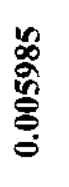 & $\begin{array}{l}\stackrel{9}{\circ} \\
\stackrel{0}{0} \\
\stackrel{0}{0} \\
\stackrel{0}{0}\end{array}$ & 串 & 密 & 突 & స్ & 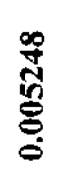 & $\stackrel{5}{\stackrel{5}{\circ}}$ & $\begin{array}{l}\stackrel{2}{*} \\
\stackrel{0}{0} \\
\stackrel{0}{0}\end{array}$ & 吕 & 容 & 产 & 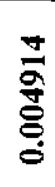 & 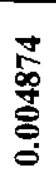 & $\begin{array}{l}\text { o. } \\
\frac{0}{0} \\
\stackrel{0}{0} \\
0\end{array}$ & 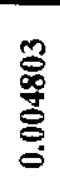 & $\begin{array}{l}80 \\
0 \\
0 \\
0\end{array}$ & 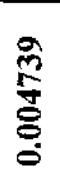 & $\begin{array}{l}\stackrel{8}{0} \\
\stackrel{0}{0} \\
\stackrel{0}{0}\end{array}$ & 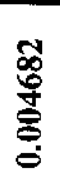 & 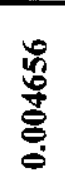 \\
\hline
\end{tabular}


Table 3.1. Power peaking factors for various FA arrangements depending on the boundary conditions

\begin{tabular}{|c|c|c|c|c|c|}
\hline Variant & Fuel & $\mathrm{Kk}_{\max }-\mathrm{CS}$ & Variant & Fuel & $\mathrm{Kk}_{\max }-\mathrm{CS}$ \\
\hline \multirow{4}{*}{ Vl } & $\mathrm{UO}_{2}$ & 1.301 & \multirow{4}{*}{ V2 } & \multirow{2}{*}{$\mathrm{UO}_{2}$} & 1.305 \\
\hline & & 1.266 & & & 1.266 \\
\hline & \multirow{2}{*}{ 1/3 MOX } & 1.393 & & \multirow[t]{2}{*}{ 1/3 MOX } & 1.451 \\
\hline & & 1.327 & & & 1.327 \\
\hline \multirow{4}{*}{ V3 } & $\mathrm{UO}_{2}$ & 1.509 & \multirow{4}{*}{ V4 } & \multirow{2}{*}{$\mathrm{UO}_{2}$} & 1.560 \\
\hline & & 1.281 & & & 1.359 \\
\hline & \multirow{2}{*}{$1 / 3 \mathrm{MOX}$} & 1.529 & & \multirow{2}{*}{ 1/3 MOX } & 1.617 \\
\hline & & 1.331 & & & 1.379 \\
\hline \multirow{4}{*}{ V5 } & $\mathrm{UO}_{2}$ & 1.405 & \multirow{4}{*}{ V6 } & \multirow{2}{*}{$\mathrm{UO}_{2}$} & 1.404 \\
\hline & & 1.377 & & & 1.377 \\
\hline & \multirow{2}{*}{ 1/3 MOX } & 1.445 & & \multirow{2}{*}{$1 / 3 \mathrm{MOX}$} & 1.444 \\
\hline & & 1.418 & & & 1.418 \\
\hline
\end{tabular}


RUSSIAN RESEARCH CENTER KURCHATOV INSTITUTE

Design Studies of "100\%Pu" MOX Lead Test Assembly (Report for FY99)

Table 3.2. Power peaking factors in system with non-zonned MOX FA at $x_{P^{\prime} w^{\prime}}=3.7 \%$

\begin{tabular}{|c|c|c|c|c|c|c|}
\hline $\mathrm{T}$ (EFPD) & $K_{K_{\max }}-C S$ & $K_{K \max }-C A$ & $K \overline{\max -\mathrm{CA}}$ & $K_{K \max }-C S$ & $K_{K \max }-C A$ & $K \overline{k \max -\mathrm{CA}}$ \\
\hline & \multicolumn{3}{|c|}{ V1 } & \multicolumn{3}{|c|}{ V2 } \\
\hline 0 & 1.451 & 1.451 & 1.150 & 1.452 & 1.452 & 1.150 \\
\hline 50 & 1.426 & 1.426 & 1.134 & 1.426 & 1.426 & 1.133 \\
\hline 100 & 1.414 & 1.414 & 1.129 & 1.414 & 1.414 & 1.130 \\
\hline 150 & 1.406 & 1.406 & 1.129 & 1.406 & 1.406 & 1.131 \\
\hline 200 & 1.400 & 1.400 & 1.130 & 1.398 & 1.398 & 1.130 \\
\hline 250 & 1.394 & 1.394 & 1.131 & 1.391 & 1.391 & 1.132 \\
\hline \multirow[t]{2}{*}{292} & 1.387 & 1.387 & 1.133 & 1.385 & 1.385 & 1.133 \\
\hline & \multicolumn{3}{|c|}{ V3 } & \multicolumn{3}{|c|}{ V4 } \\
\hline 0 & 1.462 & 1.462 & 1.147 & 1.615 & 1.615 & 1.210 \\
\hline 50 & 1.436 & 1.436 & 1.333 & 1.567 & 1.567 & 1.188 \\
\hline 100 & 1.424 & 1.424 & 1.128 & 1.534 & 1.534 & 1.179 \\
\hline 150 & 1.415 & 1.415 & 1.128 & 1.509 & 1.509 & 1.175 \\
\hline 200 & 1.408 & 1.408 & 1.129 & 1.488 & 1.488 & 1.173 \\
\hline 250 & 1.402 & 1.402 & 1.131 & 1.469 & 1.469 & 1.170 \\
\hline \multirow[t]{2}{*}{292} & 1.395 & 1.395 & 1.132 & 1.454 & 1.454 & 1.169 \\
\hline & \multicolumn{3}{|c|}{ V5 } & \multicolumn{3}{|c|}{ V6 } \\
\hline 0 & 1.687 & 1.687 & 1.260 & 1.687 & 1.687 & 1.260 \\
\hline 50 & 1.630 & 1.630 & 1.233 & 1.630 & 1.630 & 1.233 \\
\hline 100 & 1.591 & 1.591 & 1.219 & 1.591 & 1.591 & 1.219 \\
\hline 150 & 1.560 & 1.560 & 1.209 & 1.560 & 1.560 & 1.209 \\
\hline 200 & 1.534 & 1.534 & 1.202 & 1.534 & 1.534 & 1.203 \\
\hline 250 & 1.511 & 1.511 & 1.197 & 1.511 & 1.511 & 1.197 \\
\hline 292 & 1.494 & 1.494 & 1.193 & 1.494 & 1.494 & 1.193 \\
\hline
\end{tabular}


RUSSIAN RESEARCH CENTER KURCHATOV INSTITUTE

Design Studies of "100\% Pu" MOX Lead Test Assembly (Report for FY99)

Table 3.3. Power peaking factors in system with zonned MOX FA at $x_{P_{u} t}=4.4 \% / 3.4 \% / 2.6 \%$

\begin{tabular}{|c|c|c|c|c|c|c|}
\hline $\mathrm{T}(\mathrm{EFPD})$ & $K_{K \max }-C S$ & $K_{K \max }-C A$ & $K \overline{\mathrm{kmax}-\mathrm{CA}}$ & $K_{K \max }-C S$ & $K_{K \max }-C A$ & $K \overline{k \max -\overline{C A}}$ \\
\hline & \multicolumn{3}{|c|}{ V1 } & \multicolumn{3}{|c|}{ v2 } \\
\hline 0 & 1.300 & 1.280 & 1.147 & 1.300 & 1.281 & 1.147 \\
\hline 50 & 1.287 & 1.247 & 1.131 & 1.287 & 1.247 & 1.130 \\
\hline 100 & 1.267 & 1.225 & 1.125 & 1.268 & 1.225 & 1.124 \\
\hline 150 & 1.247 & 1.223 & 1.125 & 1.247 & 1.223 & 1.125 \\
\hline 200 & 1.229 & 1.224 & 1.124 & 1.229 & 1.224 & 1.125 \\
\hline 250 & 1.229 & 1.229 & 1.128 & 1.227 & 1.229 & 1.126 \\
\hline \multirow[t]{2}{*}{292} & 1.229 & 1.229 & 1.127 & 1.228 & 1.228 & 1.126 \\
\hline & \multicolumn{3}{|c|}{ V3 } & \multicolumn{3}{|c|}{ V4 } \\
\hline 0 & 1.307 & 1.290 & 1.147 & 1.426 & 1.426 & 1.205 \\
\hline 50 & 1.294 & 1.255 & 1.129 & 1.371 & 1.371 & 1.183 \\
\hline 100 & 1.274 & 1.234 & 1.124 & 1.331 & 1.331 & 1.174 \\
\hline 150 & 1.254 & 1.227 & 1.123 & 1.302 & 1.297 & 1.168 \\
\hline 200 & 1.235 & 1.228 & 1.124 & 1.277 & 1.272 & 1.165 \\
\hline 250 & 1.230 & 1.230 & 1.124 & 1.269 & 1.269 & 1.163 \\
\hline \multirow[t]{2}{*}{292} & 1.232 & 1.232 & 1.125 & 1.266 & 1.266 & 1.160 \\
\hline & \multicolumn{3}{|c|}{ V5 } & \multicolumn{3}{|c|}{ V6 } \\
\hline 0 & 1.492 & 1.492 & 1.255 & 1.491 & 1.491 & 1.254 \\
\hline 50 & 1.426 & 1.426 & 1.226 & 1.426 & 1.426 & 1.227 \\
\hline 100 & 1.379 & 1.379 & 1.211 & 1.379 & 1.379 & 1.211 \\
\hline 150 & 1.340 & 1.340 & 1.201 & 1.340 & 1.340 & 1.201 \\
\hline 200 & 1.307 & 1.307 & 1.193 & 1.307 & 1.307 & 1.193 \\
\hline 250 & 1.289 & 1.289 & 1.187 & 1.288 & 1.288 & 1.187 \\
\hline 292 & 1.285 & 1.285 & 1.183 & 1.285 & 1.285 & 1.183 \\
\hline
\end{tabular}


RUSSIAN RESEARCH CENTER KURCHATOV INSTITUTE

Design Studies of " $100 \%$ Pu" MOX Lead Test Assembly (Report for FY99)

Table 3.4. Power peaking factors in system with zonned MOX FA at $x_{P_{u} f}=4.5 \% / 3.4 \% / 2.4 \%$

\begin{tabular}{|c|c|c|c|c|c|c|}
\hline $\begin{array}{c}\mathrm{T} \\
\text { (EFPD) } \\
\end{array}$ & $K_{K \max }-C S$ & $K_{K \max }-C A$ & $K \overline{\text { max }-\overline{C A}}$ & $K_{K \max }-C S$ & $K_{K \max }-C A$ & $K \overline{k \max -\overline{C A}}$ \\
\hline & \multicolumn{3}{|c|}{ V1 } & \multicolumn{3}{|c|}{ V2 } \\
\hline 0 & 1.298 & 1.250 & 1.148 & 1.298 & 1.250 & 1.148 \\
\hline 50 & 1.286 & 1.231 & 1.131 & 1.286 & 1.231 & 1.131 \\
\hline 100 & 1.266 & 1.226 & 1.125 & 1.265 & 1.227 & 1.126 \\
\hline 150 & 1.246 & 1.227 & 1.124 & 1.246 & 1.227 & 1.124 \\
\hline 200 & 1.232 & 1.232 & 1.127 & 1.230 & 1.230 & 1.126 \\
\hline 250 & 1.232 & 1.232 & 1.126 & 1.233 & 1.233 & 1.126 \\
\hline 292 & 1.234 & 1.234 & 1.126 & 1.234 & 1.234 & 1.126 \\
\hline & \multicolumn{3}{|c|}{ V3 } & \multicolumn{3}{|c|}{ V4 } \\
\hline 0 & 1.305 & 1.258 & 1.147 & 1.379 & 1.374 & 1.206 \\
\hline 50 & 1.292 & 1.242 & 1.131 & 1.358 & 1.319 & 1.183 \\
\hline 100 & 1.273 & 1.237 & 1.124 & 1.329 & 1.294 & 1.173 \\
\hline 150 & 1.252 & 1.237 & 1.123 & 1.300 & 1.288 & 1.169 \\
\hline 200 & 1.241 & 1.241 & 1.124 & 1.283 & 1.283 & 1.164 \\
\hline 250 & 1.242 & 1.242 & 1.125 & 1.281 & 1.281 & 1.162 \\
\hline 292 & 1.246 & 1.246 & 1.127 & 1.278 & 1.278 & 1.160 \\
\hline & \multicolumn{3}{|c|}{ V5 } & \multicolumn{3}{|c|}{ V6 } \\
\hline 0 & 1.437 & 1.437 & 1.254 & 1.436 & 1.436 & 1.254 \\
\hline 50 & 1.372 & 1.372 & 1.225 & 1.372 & 1.372 & 1.225 \\
\hline 100 & 1.342 & 1.342 & 1.210 & 1.342 & 1.342 & 1.210 \\
\hline 150 & 1.313 & 1.313 & 1.200 & 1.313 & 1.313 & 1.200 \\
\hline 200 & 1.306 & 1.306 & 1.192 & 1.306 & 1.306 & 1.192 \\
\hline 250 & 1.301 & 1.301 & 1.186 & 1.301 & 1.301 & 1.186 \\
\hline 292 & 1.297 & 1.297 & 1.181 & 1.297 & 1.297 & 1.181 \\
\hline
\end{tabular}


RUSSIAN RESEARCH CENTER KURCHATOV INSTITUTE

Design Studies of "100\%Pu" MOX Lead Test Assembly (Report for FY99)

Table 3.5. Power peaking factors in system with zonned MOX FA at $x_{p_{u^{\prime}}}=4.6 \% / 3.4 \% / 2.2 \%$

\begin{tabular}{|c|c|c|c|c|c|c|}
\hline $\begin{array}{c}\mathrm{T} \\
\text { (EFPD) }\end{array}$ & $K_{K \max }-C S$ & $K_{K_{\max }}-C A$ & $K \overline{\max -\overline{C A}}$ & $K_{K \max }-C S$ & $K_{K \max }-C A$ & $K \overline{k \max -\overline{\mathrm{CA}}}$ \\
\hline & \multicolumn{3}{|c|}{$\mathbf{V 1}$} & \multicolumn{3}{|c|}{$\mathbf{V} 2$} \\
\hline 0 & 1.299 & 1.253 & 1.142 & 1.299 & 1.253 & 1.141 \\
\hline 50 & 1.285 & 1.236 & 1.125 & 1.285 & 1.235 & 1.125 \\
\hline 100 & 1.264 & 1.231 & 1.120 & 1.264 & 1.230 & 1.119 \\
\hline 150 & 1.244 & 1.231 & 1.118 & 1.244 & 1.231 & 1.118 \\
\hline 200 & 1.234 & 1.234 & 1.119 & 1.234 & 1.234 & 1.119 \\
\hline 250 & 1.238 & 1.238 & 1.121 & 1.238 & 1.238 & 1.121 \\
\hline \multirow[t]{2}{*}{292} & 1.239 & 1.239 & 1.121 & 1.239 & 1.239 & 1.120 \\
\hline & \multicolumn{3}{|c|}{ V3 } & \multicolumn{3}{|c|}{ V4 } \\
\hline 0 & 1.305 & 1.262 & 1.140 & 1.380 & 1.333 & 1.199 \\
\hline 50 & 1.292 & 1.245 & 1.124 & 1.355 & 1.310 & 1.177 \\
\hline 100 & 1.270 & 1.241 & 1.119 & 1.325 & 1.298 & 1.167 \\
\hline 150 & 1.249 & 1.243 & 1.119 & 1.295 & 1.291 & 1.162 \\
\hline 200 & 1.246 & 1.246 & 1.119 & 1.288 & 1.288 & 1.159 \\
\hline 250 & 1.246 & 1.246 & 1.119 & 1.285 & 1.285 & 1.156 \\
\hline \multirow[t]{2}{*}{292} & 1.248 & 1.248 & 1.119 & 1.282 & 1.282 & 1.112 \\
\hline & \multicolumn{3}{|c|}{ V5 } & \multicolumn{3}{|c|}{ V6 } \\
\hline 0 & 1.394 & 1.382 & 1.247 & 1.393 & 1.382 & 1.247 \\
\hline 50 & 1.370 & 1.339 & 1.218 & 1.370 & 1.339 & 1.218 \\
\hline 100 & 1.338 & 1.325 & 1.203 & 1.338 & 1.325 & 1.203 \\
\hline 150 & 1.316 & 1.316 & 1.192 & 1.316 & 1.316 & 1.193 \\
\hline 200 & 1.310 & 1.310 & 1.184 & 1.310 & 1.310 & 1.185 \\
\hline 250 & 1.305 & 1.305 & 1.178 & 1.305 & 1.305 & 1.178 \\
\hline 292 & 1.301 & 1.301 & 1.173 & 1.301 & 1.301 & 1.174 \\
\hline
\end{tabular}


RUSSIAN RESEARCH CENTER KURCHATOV INSTITUTE

Design Studies of " $100 \%$ Pu" MOX Lead Test Assembly (Report for FY99)

Table 3.6. Power peaking factors in system with zonned MOX FA at $x_{P u^{\prime}}=4.7 \% / 3.4 \% / 2.0 \%$

\begin{tabular}{|c|c|c|c|c|c|c|}
\hline $\mathrm{T}$ (EFPD) & $K_{K \max }-C S$ & $K_{K \max }-C A$ & $K \overline{\mathrm{kmax}-\mathrm{CA}}$ & $K_{K \max }-C S$ & $K_{K \max }-C A$ & $K \overline{\overline{\max -\mathrm{CA}}}$ \\
\hline & \multicolumn{3}{|c|}{ V1 } & \multicolumn{3}{|c|}{$\mathrm{V} 2$} \\
\hline 0 & 1.302 & 1.263 & 1.140 & 1.302 & 1.262 & 1.140 \\
\hline 50 & 1.289 & 1.245 & 1.122 & 1.289 & 1.246 & 1.123 \\
\hline 100 & 1.269 & 1.242 & 1.117 & 1.268 & 1.244 & 1.119 \\
\hline 150 & 1.248 & 1.245 & 1.117 & 1.249 & 1.244 & 1.116 \\
\hline 200 & 1.248 & 1.248 & 1.116 & 1.247 & 1.247 & 1.116 \\
\hline 250 & 1.251 & 1.251 & 1.117 & 1.250 & 1.250 & 1.117 \\
\hline 292 & 1.254 & 1.254 & 1.118 & 1.253 & 1.253 & 1.118 \\
\hline & \multicolumn{3}{|c|}{$\mathrm{V3}$} & \multicolumn{3}{|c|}{ V4 } \\
\hline 0 & 1.308 & 1.281 & 1.139 & 1.384 & 1.354 & 1.197 \\
\hline 50 & 1.296 & 1.264 & 1.122 & 1.362 & 1.330 & 1.174 \\
\hline 100 & 1.276 & 1.259 & 1.115 & 1.331 & 1.320 & 1.165 \\
\hline 150 & 1.262 & 1.262 & 1.115 & 1.315 & 1.315 & 1.160 \\
\hline 200 & 1.265 & 1.265 & 1.116 & 1.310 & 1.310 & 1.156 \\
\hline 250 & 1.267 & 1.267 & 1.117 & 1.308 & 1.308 & 1.153 \\
\hline 292 & 1.270 & 1.270 & 1.118 & 1.305 & 1.305 & 1.151 \\
\hline & \multicolumn{3}{|c|}{$\mathrm{V5}$} & \multicolumn{3}{|c|}{ V6 } \\
\hline 0 & 1.398 & 1.388 & 1.245 & 1.397 & 1.388 & 1.245 \\
\hline 50 & 1.375 & 1.361 & 1.216 & 1.375 & 1.361 & 1.216 \\
\hline 100 & 1.347 & 1.347 & 1.201 & 1.347 & 1.347 & 1.201 \\
\hline 150 & 1.339 & 1.339 & 1.191 & 1.339 & 1.339 & 1.191 \\
\hline 200 & 1.334 & 1.334 & 1.183 & 1.334 & 1.334 & 1.183 \\
\hline 250 & 1.328 & 1.328 & 1.177 & 1.328 & 1.328 & 1.177 \\
\hline 292 & 1.325 & 1.325 & 1.172 & 1.325 & 1.325 & 1.172 \\
\hline
\end{tabular}


Table 3.7. Fuel reloading schemes

\begin{tabular}{|c|cc|ccc|}
\hline & 1 & 2 & 3 & 4 \\
\hline \hline $\mathrm{UO}_{2}$ & $101 \rightarrow 201$ & $101 \rightarrow 202$ & $101 \rightarrow 201$ & $101 \rightarrow 202$ \\
$\mathrm{UO}_{2}$ & $102 \rightarrow 202$ & $102 \rightarrow 201$ & $102 \rightarrow 202$ & $102 \rightarrow 201$ \\
$\mathrm{MOX}$ & $103 \rightarrow 203$ & $103 \rightarrow 203$ & $103 \rightarrow 203$ & $103 \rightarrow 203$ \\
$\mathrm{UO}_{2}$ & $201 \rightarrow 301$ & $201 \rightarrow 301$ & $201 \rightarrow 302$ & $201 \rightarrow 302$ \\
$\mathrm{UO}_{2}$ & $202 \rightarrow 302$ & $202 \rightarrow 302$ & $202 \rightarrow 301$ & $202 \rightarrow 301$ \\
$\mathrm{MOX}$ & $203 \rightarrow 303$ & $203 \rightarrow 303$ & $203 \rightarrow 303$ & $203 \rightarrow 303$ \\
\hline
\end{tabular}


RUSSIAN RESEARCH CENTER KURCHATOV INSTITUTE

Design Studies of "100\%Pu" MOX Lead Test Assembly (Report for FY99)

Table 3.8. Effect of fuel reloading scheme on the $K_{K}-C S$ value. Cycle № 5 . $x_{P_{u} f}=4.6 \% / 3.4 \% / 2.2 \%$

\begin{tabular}{|c|c|c|c|c|c|c|c|c|}
\hline $\begin{array}{c}\mathrm{T} \\
\text { (EFPD) }\end{array}$ & 1 & 2 & 3 & 4 & 1 & 2 & 3 & 4 \\
\hline & \multicolumn{3}{|c|}{ V1 } & & \multicolumn{4}{|c|}{ V2 } \\
\hline 0 & 1.307 & 1.308 & 1.308 & 1.308 & 1.308 & 1.307 & 1.308 & 1.308 \\
\hline 50 & 1.282 & 1.283 & 1.283 & 1.283 & 1.283 & 1.283 & 1.283 & 1.284 \\
\hline 100 & 1.262 & 1.262 & 1.262 & 1.262 & 1.262 & 1.261 & 1.262 & 1.262 \\
\hline 150 & 1.241 & 1.241 & 1.241 & 1.242 & 1.242 & 1.241 & 1.241 & 1.242 \\
\hline 200 & 1.233 & 1.231 & 1.233 & 1.232 & 1.232 & 1.232 & 1.232 & 1.232 \\
\hline 250 & 1.236 & 1.235 & 1.235 & 1.235 & 1.235 & 1.236 & 1.234 & 1.235 \\
\hline 292 & 1.238 & 1.237 & 1.237 & 1.237 & 1.237 & 1.237 & 1.237 & 1.237 \\
\hline & \multicolumn{3}{|c|}{ V3 } & & \multicolumn{3}{|c|}{ V4 } & \\
\hline 0 & 1.314 & 1.314 & 1.314 & 1.314 & 1.406 & 1.404 & 1.405 & 1.407 \\
\hline 50 & 1.289 & 1.289 & 1.289 & 1.287 & 1.362 & 1.361 & 1.362 & 1.363 \\
\hline 100 & 1.268 & 1.268 & 1.268 & 1.268 & 1.329 & 1.328 & 1.329 & 1.330 \\
\hline 150 & 1.247 & 1.247 & 1.247 & 1.247 & 1.300 & 1.298 & 1.299 & 1.301 \\
\hline 200 & 1.241 & 1.242 & 1.243 & 1.242 & 1.293 & 1.291 & 1.292 & 1.294 \\
\hline 250 & 1.244 & 1.245 & 1.244 & 1.245 & 1.290 & 1.288 & 1.291 & 1.291 \\
\hline \multirow[t]{2}{*}{292} & 1.247 & 1.245 & 1.246 & 1.245 & 1.287 & 1.285 & 1.289 & 1.289 \\
\hline & \multicolumn{3}{|c|}{ V5 } & & \multicolumn{3}{|c|}{ V6 } & \\
\hline 0 & 1.417 & 1.418 & 1.418 & 1.416 & 1.418 & 1.417 & 1.418 & 1.418 \\
\hline 50 & 1.377 & 1.376 & 1.377 & 1.377 & 1.377 & 1.377 & 1.377 & 1.377 \\
\hline 100 & 1.343 & 1.344 & 1.345 & 1.345 & 1.344 & 1.344 & 1.345 & 1.345 \\
\hline 150 & 1.322 & 1.322 & 1.324 & 1.324 & 1.322 & 1.323 & 1.323 & 1.324 \\
\hline 200 & 1.316 & 1.316 & 1.318 & 1.317 & 1.315 & 1.316 & 1.317 & 1.317 \\
\hline 250 & 1.311 & 1.311 & 1.313 & 1.312 & 1.310 & 1.311 & 1.312 & 1.312 \\
\hline 292 & 1.307 & 1.307 & 1.308 & 1.308 & 1.306 & 1.307 & 1.308 & 1.308 \\
\hline
\end{tabular}


RUSSIAN RESEARCH CENTER KURCHATOV INSTITUTE

Design Studies of "100\%Pu" MOX Lead Test Assembly (Report for FY99)

Table 4.1. Limiting parameters for VVER-1000

\begin{tabular}{|c|c|c|}
\hline Criterion & Limiting Value & Remarks \\
\hline$\overline{K q}$ & $<=1.35$ & $\begin{array}{c}\text { For nominal power } \\
\mathrm{W}=3000 \mathrm{MW}\end{array}$ \\
\hline $\mathbf{K r}$ & $<=1.60$ & $\begin{array}{c}\text { For nominal power } \\
\mathrm{W}=3000 \mathrm{MW}\end{array}$ \\
\hline $\mathrm{K}_{0 \text {-total }}$ & Tabl. 3.2 & $\begin{array}{c}\text { For nominal power } \\
\text { W=3000 MW }\end{array}$ \\
\hline MTC & $<0$ & \\
\hline MDC & $>0$ & \\
\hline RO stop & $<=-2000 \mathrm{pcm}$ & $\begin{array}{c}t=20^{\circ} \mathrm{C}, \mathrm{Xe}=0, \\
\mathrm{Sm}=\mathrm{Smh}, \mathrm{Cb}=16000 \\
\text { ppm, } \\
\text { all control rods } \\
\text { extracted }\end{array}$ \\
\hline RCT & $<220^{\circ} \mathrm{C}$ & \\
\hline$(\mathbf{R O})_{\mathrm{AP}-1}$ & $>5500 \mathrm{pcm}$ & In full power \\
\hline
\end{tabular}

Table 4.2. Limits recommended for total power peaking factor $K_{\text {o-total }}$ for VVER-1000

\begin{tabular}{|l|l|l|l|l|l|l|l|l|l|l|}
\hline $\begin{array}{l}\text { Layer } \\
\text { (from bottom } \\
\text { to top) }\end{array}$ & 1 & 2 & 3 & 4 & 5 & 6 & 7 & 8 & 9 & 10 \\
\hline $\mathrm{K}_{\text {o-total }}$ & 2.24 & 2.24 & 2.24 & 2.24 & 2.24 & 2.14 & 1.96 & 1.80 & 1.69 & 1.58 \\
\hline
\end{tabular}


RUSSIAN RESEARCH CENTER KURCHATOV INSTITUTE

Design Studies of "100\%Pu" MOX Lead Test Assembly (Report for FY99)

Table 4.3. Recommended limiting parameters for VVER-1000 with 3 MOX LTAs.

\begin{tabular}{|c|c|c|}
\hline Criterion & Limiting Value & Remarks \\
\hline $\mathrm{Kg}$ & $<=1.35$ & \\
\hline $\mathbf{K r}$ & $<=1.55$ & $\begin{array}{c}\text { In MOX assemblies. For } \\
\text { nominal power } \mathrm{W}=\mathbf{3 0 0 0} \\
\text { MW }\end{array}$ \\
\hline $\mathrm{K}_{0 \text {-total }}$ & Tabl. 3.4 & $\begin{array}{l}\text { In MOX assemblies. For } \\
\text { nominal power } W=3000 \\
\text { MW }\end{array}$ \\
\hline MTC & $<0$ & \\
\hline MDC & $>0$ & \\
\hline RO stop & $<=-2000 \mathrm{pcm}$ & $\begin{array}{c}\mathrm{t}=20^{\circ} \mathrm{C}, \mathrm{Xe}=0, \\
\mathrm{Sm}=\mathrm{Smh}, \mathrm{Cb}=16000 \\
\mathrm{ppm}, \\
\text { all control rods } \\
\text { extracted }\end{array}$ \\
\hline RCT & $<210^{\circ} \mathrm{C}$ & \\
\hline$(\mathrm{RO})_{\mathrm{AP}-\mathrm{I}}$ & $\geq 5500 \mathrm{pcm}$ & In full power \\
\hline
\end{tabular}

Table 4.4. Limits recommended for total power peaking factor $\mathbf{K}_{\mathrm{o} \text {-total }}$ in MOX assemblies for VVER-1000 with 3 MOX LTAs

\begin{tabular}{|l|l|l|l|l|l|l|l|l|l|l|}
\hline $\begin{array}{l}\text { Layer } \\
\text { (from bottom } \\
\text { to top) }\end{array}$ & 1 & 2 & 3 & 4 & 5 & 6 & 7 & 8 & 9 & 10 \\
\hline $\mathrm{K}_{\text {0-total }}$ & 2.17 & 2.17 & 2.17 & 2.17 & 2.17 & 2.07 & 1.90 & 1.74 & 1.64 & 1.53 \\
\hline
\end{tabular}


Table 4.5. Evolution of main neutronics parameters in Uranium reference core . Equilibrium cycle

$\operatorname{Sim}=60, x e=1.5 \mathrm{~m}=3$

\begin{tabular}{|c|c|c|c|c|c|c|c|c|c|c|c|c|c|c|c|c|c|c|c|c|c|c|c|}
\hline$\mu$ & $\begin{array}{c}\mathrm{T} \\
\text { EFPD }\end{array}$ & $\begin{array}{c}\mathrm{H}_{\mathrm{req}} \\
\mathrm{cm}\end{array}$ & $\begin{array}{l}t_{\text {entry }} \\
{ }^{\circ} \mathrm{C}\end{array}$ & $\underset{M W}{W}$ & $\begin{array}{l}\mathrm{Cb}^{\mathrm{erl}} \\
\mathrm{ppm}\end{array}$ & $\underset{\mathrm{m}^{3} / \mathrm{h}}{\mathbf{G}}$ & $\mathrm{Kq}$ & Nk & $K q^{x 0 x}$ & Nk & $\mathbf{K v}$ & Nk & $\mathbf{N z}$ & $\begin{array}{c}\overline{\mathrm{B}}_{\mathrm{U}} \\
\mathrm{MW} \\
\mathrm{d} / \mathrm{kg}\end{array}$ & $\begin{array}{l}\overline{\mathrm{B}}_{\text {Mox }} \\
\mathrm{MW \cdot} \\
\mathrm{d} / \mathrm{kg}\end{array}$ & $\begin{array}{c}\mathrm{MDC} \\
\mathrm{pcm} \cdot \\
\left(\mathrm{g} / \mathrm{cm}^{3}\right)^{-1}\end{array}$ & $\begin{array}{l}\text { MTC } \\
\text { pcme } \\
{ }^{\circ} \mathrm{C}^{-1}\end{array}$ & $\begin{array}{c}\text { DTC } \\
\text { pem* } \\
{ }^{\circ} \mathrm{C}^{-1}\end{array}$ & $\begin{array}{l}\text { DTC } \\
\text { pcme } \\
{ }^{\circ} \mathrm{C}^{-1}\end{array}$ & $\begin{array}{c}\mathrm{DPC} \\
\mathrm{pcrr} \bullet \\
\mathrm{MW}^{-1}\end{array}$ & $\begin{array}{c}\mathrm{DRo} / \mathrm{DCb} \\
\mathrm{pcm} \cdot \\
\mathrm{ppm}^{-1}\end{array}$ & $\begin{array}{l}\boldsymbol{\beta}_{\mathrm{ef}} \\
\text { pcm }\end{array}$ & $\begin{array}{l}\mathrm{l}_{\mathrm{Im}} \\
\cdot 10^{5} \\
\mathrm{sec}\end{array}$ \\
\hline 1 & 0.0 & 263.2 & 287.0 & 3000 & 5657 & 84000 & 1.31 & 19 & 0.00 & 0 & 1.61 & 19 & 4 & 14.14 & 0.00 & 12293 & -25.94 & -2.96 & -2.46 & -0.29 & -1.55 & 650 & 2.24 \\
\hline 2 & 20.0 & 283.2 & 287.0 & 3000 & 5318 & 84000 & 1.31 & 19 & 0.00 & 0 & 1.58 & 19 & 4 & 15.00 & 0.00 & 12894 & -26.94 & -2.96 & -2.47 & -0.29 & -1.55 & 639 & 2.24 \\
\hline 3 & 40.0 & 283.2 & 287.0 & 3000 & 4899 & 84000 & 1.31 & 19 & 0.00 & 0 & 1.56 & 19 & 4 & 15.85 & 0.00 & 14000 & -29.20 & -2.94 & -2.48 & -0.29 & -1.56 & 630 & 2.25 \\
\hline 4 & 60.0 & 283.2 & 287.0 & 3000 & 4473 & 84000 & 1.31 & 19 & 0.00 & 0 & 1.53 & 19 & 3 & 16.70 & 0.00 & 15191 & -31.69 & -2.93 & -2.50 & -0.29 & 57 & 622 & 2.27 \\
\hline 5 & 80.0 & 283.2 & 287.0 & 3000 & 4047 & 84000 & 1.31 & 19 & 0.00 & 0 & 1.52 & 19 & 3 & 17.55 & 0.00 & 16400 & -34.24 & -2.93 & -2.52 & -0.29 & -1.58 & 613 & 2.29 \\
\hline 6 & 100.0 & 283.2 & 287.0 & 3000 & 3631 & 84000 & 1.31 & 19 & 0.00 & 0 & 1.51 & 19 & 3 & 18.41 & 0.00 & 17590 & -36.77 & -2.94 & -2.55 & -0.29 & -1.59 & 606 & 2.31 \\
\hline 7 & 120.0 & 283.2 & 287.0 & 3000 & 3215 & 84000 & 1.30 & 19 & 0.00 & 0 & 1.50 & 19 & 3 & 19.26 & 0.00 & 18775 & -39.30 & -2.96 & -2.58 & -0.29 & -1.60 & 598 & 2.33 \\
\hline 8 & 140.0 & 283.2 & 287.0 & 3000 & 2813 & 84000 & 1.30 & 19 & 0.00 & 0 & 1.49 & 19 & 3 & 20.11 & 0.00 & 19928 & -41.77 & -2.97 & -2.60 & -0.29 & -1.62 & 591 & 2.35 \\
\hline 9 & 160.0 & 283.2 & 287.0 & 3000 & 2411 & 84000 & 1.30 & 19 & 0.00 & 0 & 1.48 & 19 & 3 & 20.96 & 0.00 & 21077 & -44.25 & -2.99 & -2.63 & & -1.63 & 585 & 2.37 \\
\hline 10 & 180.0 & 283.2 & 287.0 & 3000 & 2023 & 84000 & 1.30 & 19 & 0.00 & 0 & 1.47 & 19 & 2 & 21.82 & 0.00 & 22203 & -46.69 & -3.02 & -2.66 & -0.29 & -1.64 & 578 & 2.40 \\
\hline 11 & 200.0 & 283.2 & 287.0 & 3000 & 1634 & 84000 & 1.30 & 19 & 0.00 & 0 & 1.47 & 19 & 2 & 22.67 & 0.00 & 23333 & -49.16 & -3.04 & -2.69 & -0.29 & .66 & 573 & 2.42 \\
\hline 12 & 220.0 & 283.2 & 287.0 & 3000 & 1254 & 84000 & 1.29 & 19 & 0.00 & 0 & 1.47 & 19 & 2 & 23.52 & 0.00 & 24457 & -51.62 & -3.06 & -2.71 & -0.29 & -1.67 & 567 & 2.45 \\
\hline 13 & 240.0 & 283.2 & 287.0 & 3000 & 874 & 84000 & 1.29 & 19 & 0.00 & 0 & 1.47 & 19 & 2 & 24.37 & 0.00 & 25592 & -54.13 & -3.08 & -2.74 & -0.30 & -1.68 & 562 & 2.48 \\
\hline 14 & 260.0 & 283.2 & 287.0 & 3000 & 500 & 84000 & 1.29 & 19 & 0.00 & 0 & 1.46 & 19 & 2 & 25.23 & 0.00 & 26727 & -56.64 & -3.09 & -2.76 & -0.30 & .70 & 557 & 2.51 \\
\hline 15 & 280.0 & 283.2 & 287.0 & 3000 & 127 & 84000 & 1.28 & 19 & 0.00 & 0 & 1.46 & 19 & 2 & 26.08 & 0.00 & 27869 & -59.18 & -3.11 & -2.79 & -0.30 & -1.71 & 552 & 2.54 \\
\hline 16 & 286.9 & 283.2 & 287.0 & 3000 & 0 & 84000 & 1.28 & 19 & 0.00 & 0 & 1.45 & 19 & 2 & 26.37 & 0.00 & 28260 & -60.05 & -3.12 & -2.80 & -0.30 & -1.72 & 551 & 2.55 \\
\hline
\end{tabular}


Table 4.6. Main neutronics parameters in zero power states. Reference Uranium Core Equilibrium Cycle

\begin{tabular}{|c|c|c|c|c|c|c|c|c|c|c|c|c|c|}
\hline $\mathbf{T}$ & $\begin{array}{l}\text { RO } \\
\text { pcm }\end{array}$ & $\begin{array}{c}\text { Cb } \\
\text { ppm }\end{array}$ & Bank 10 & $\begin{array}{c}\text { Other } \\
\text { banks } \downarrow \uparrow\end{array}$ & $\mathbf{X e}$ & Sm & $\underset{{ }^{\circ} \mathrm{C}}{\text { Tmod }}$ & $\begin{array}{c}\text { MTC } \\
\mathrm{pcm} /{ }^{\circ} \mathrm{C}\end{array}$ & $\begin{array}{c}\mathrm{MDC} \\
\mathrm{pcm} / \mathrm{g} / \mathrm{cc}\end{array}$ & $\begin{array}{c}\text { DTC } \\
\mathrm{pcm} /{ }^{\circ} \mathrm{C}\end{array}$ & $\begin{array}{l}\mathrm{DRO} / \mathrm{DCB} \\
\mathrm{pem} / \mathrm{ppm}\end{array}$ & $\begin{array}{r}\lambda \mathrm{m} \\
* 10^{5} \mathrm{~s}\end{array}$ & $\begin{array}{l}\beta \text { Beff } \\
* 100\end{array}$ \\
\hline BOC & 0 & 8860 & $100 \% \uparrow$ & $100 \% \uparrow$ & 0 & Smh & 280 & -1.23 & 2210 & -2.93 & -1.49 & 2.10 & 0.65 \\
\hline EOC & 0 & 2000 & $100 \% \uparrow$ & $100 \% \uparrow$ & eq & Sm eq & 280 & -27.52 & 18730 & -3.31 & -1.76 & 2.44 & 0.57 \\
\hline$\overline{\mathrm{BOC}}$ & $\begin{array}{c}-14237 \\
\left(\mathrm{RO}_{\text {STOP }}\right)\end{array}$ & 16000 & $100 \% \uparrow$ & $100 \% \uparrow$ & $\mathbf{0}$ & Smh & 20 & & & & & & \\
\hline
\end{tabular}


Table 4.7. Evolution of main neutronics parameters. First cycle with 3 MOX LTAs of "100\%Pu" type

$\operatorname{Sim}=360, X e=1, S m=3$

\begin{tabular}{|c|c|c|c|c|c|c|c|c|c|c|c|c|c|c|c|c|c|c|c|c|c|c|c|}
\hline 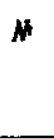 & $\begin{array}{c}\mathrm{T} \\
\mathrm{EFPD}\end{array}$ & $\begin{array}{c}\mathrm{H}_{\text {res }} \\
\mathrm{cm}\end{array}$ & $\begin{array}{c}t_{\text {mentry }} \\
{ }^{\circ} \mathrm{C}\end{array}$ & $\begin{array}{c}W \\
\text { MW }\end{array}$ & $\begin{array}{l}\mathrm{Cb}^{\text {erth }} \\
\text { ppm }\end{array}$ & $\begin{array}{c}\mathbf{G} \\
\mathrm{m}^{3} / \mathrm{h}\end{array}$ & $\mathrm{Kq}$ & Nk & $\mathrm{Kq}^{\operatorname{mox}}$ & $\mathbf{N k}$ & Kv & Nk & $\mathrm{Nz}$ & $\begin{array}{c}\bar{B}_{\mathrm{U}} \\
\mathrm{MW} \bullet \\
\mathrm{d} / \mathrm{kg}\end{array}$ & $\begin{array}{l}\overline{\mathbf{B}}_{\text {Max }} \\
\text { MW• } \\
\mathrm{d} / \mathrm{kg}\end{array}$ & $\begin{array}{c}\mathrm{MDC} \\
\mathrm{pcm} \cdot \\
\left(\mathrm{g} / \mathrm{cm}^{3}\right)^{-1}\end{array}$ & $\begin{array}{l}\text { MTC } \\
\text { pem॰ } \\
{ }^{\circ} \mathrm{C}^{-1}\end{array}$ & $\begin{array}{l}\text { DTC } \\
\text { pcm. } \\
{ }^{\circ} \mathrm{C}^{-1}\end{array}$ & $\begin{array}{l}\text { DTC } \\
\text { pcm• } \\
{ }^{\circ} \mathrm{C}^{-1}\end{array}$ & $\begin{array}{l}\text { DPC } \\
\text { pcm॰ } \\
\mathrm{MW}^{-1}\end{array}$ & $\begin{array}{c}\text { DRo/DCb } \\
\text { pem } \\
\mathrm{ppm}^{-1}\end{array}$ & $\begin{array}{l}\boldsymbol{\beta}_{\text {es. }} \\
\text { pem }\end{array}$ & $\begin{array}{r}\mathrm{l}_{\mathrm{im}} \\
-10^{5} \\
\mathrm{sec}\end{array}$ \\
\hline 1 & 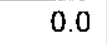 & 33.2 & 87.0 & 3000 & 784 & 1000 & 1.32 & 38 & 1.03 & 8 & 1.61 & 38 & 4 & 4.26 & 0.00 & 12029 & -25.00 & -2.88 & -2.49 & -0.28 & -1.55 & 642 & .23 \\
\hline 2 & 20.0 & 283.2 & 287.0 & 3000 & 5439 & 84000 & 1.27 & 38 & 0.98 & 8 & & 38 & 4 & 5.12 & 0.88 & 12614 & -25.94 & -2.89 & -2.51 & -0.28 & & 632 & 2.24 \\
\hline 3 & 40.0 & 283.2 & 287.0 & 3000 & 5012 & 84000 & 1.27 & 38 & 0.95 & 8 & 1.49 & 11 & 4 & 5.97 & 1.71 & 13 & -28.28 & 88 & -2.52 & -0.28 & & 624 & 2.26 \\
\hline 4 & 60.0 & 283.2 & 287.0 & 3000 & 4585 & 84000 & 1.26 & 117 & 0.93 & 8 & 1.47 & 117 & 3 & 16.82 & 2.52 & 44 & -30.82 & & -2.54 & & & 616 & 2.27 \\
\hline 5 & 80.0 & 283.2 & 287.0 & 3000 & 4152 & 84000 & 1.26 & 92 & 0.92 & 150 & 1.45 & 92 & 3 & 17.68 & 3.32 & 16173 & -33.43 & -2.89 & -2.56 & -0.28 & & 608 & 2.29 \\
\hline 6 & 100.0 & 283.2 & 287.0 & 3000 & 3725 & 84000 & 1.26 & 92 & 0.91 & 150 & 1.45 & 92 & 3 & 18.53 & 4.10 & 17390 & -36.04 & -2.90 & -2.58 & -0.28 & & 601 & 2.31 \\
\hline 7 & 120.0 & 283.2 & 287.0 & 3000 & 3298 & 84000 & 1.27 & 92 & 0.91 & 88 & 1.45 & 92 & 3 & 19.38 & 4.88 & 18604 & -38.65 & -2 & -2.61 & & & 594 & 2.33 \\
\hline 8 & 140.0 & 283.2 & 287.0 & 3000 & 2887 & 84000 & 1.27 & 92 & 0.90 & 88 & 1.44 & 92 & 3 & 20.24 & 5.66 & 85 & -41.20 & 3 & -2.63 & -0.28 & & 587 & 2.35 \\
\hline 9 & 160.0 & 283.2 & 287.0 & 3000 & 2476 & 84000 & 1.27 & 92 & 0.90 & 88 & 1.44 & 124 & 3 & 21.09 & 6.42 & & -43.75 & & -2.65 & 29 & & 1 & 2.38 \\
\hline 10 & 180.0 & 283.2 & 287.0 & 3000 & 2072 & 84000 & 1.27 & 92 & 0.89 & 88 & 1.44 & 124 & 2 & 21.95 & 7.19 & 22131 & -46.29 & -2.97 & -2.68 & -0.29 & & 575 & 2.40 \\
\hline 11 & 200.0 & 283.2 & 287.0 & 3000 & 1669 & 84000 & 1.27 & 124 & 0.89 & 88 & 1.45 & 124 & 2 & 22.80 & 7.95 & 23302 & -48.86 & -2.99 & -2.70 & -0.29 & -1.66 & 569 & 2.43 \\
\hline 12 & 220.0 & 283.2 & 287.0 & 3000 & 1276 & 84000 & 1.27 & 124 & 0.88 & 88 & 1.45 & 124 & 2 & 23.65 & 8.70 & & -51.40 & & -2.72 & & & 564 & 2.46 \\
\hline 13 & 240.0 & 283.2 & 287.0 & 3000 & 883 & 84000 & 1.28 & 124 & 0.88 & 88 & 1.46 & 124 & 2 & 24.51 & 9.46 & 27 & -53.97 & -3.03 & -2 & & & 559 & 2.49 \\
\hline 14 & 260.0 & 283.2 & 287.0 & 3000 & 491 & 84000 & 1.28 & 124 & 0.88 & 88 & 1.46 & 124 & 2 & 25.36 & 10.21 & 26802 & -56.58 & -3.04 & -2.77 & -0.29 & 71 & 554 & 2.52 \\
\hline 15 & 280.0 & 283.2 & 287.0 & 3000 & 111 & 84000 & 1.27 & 124 & 0.88 & 88 & 1.46 & 124 & 2 & 26.22 & 10.96 & 27960 & -59.14 & -3.06 & -2.79 & -0.29 & -1.72 & 549 & 2.55 \\
\hline 16 & 285.8 & 283.2 & 287.0 & 3000 & 0 & 84000 & 1.27 & 124 & 0.88 & 88 & 1.45 & 124 & 2 & 26.47 & 11.18 & 28297 & -59.90 & -3.07 & -2.79 & -0.29 & -1.73 & 548 & 2.56 \\
\hline
\end{tabular}



Table 4.9. Evolution of main neutronics parameters. Second cycle with 3 MOX LTAs of "100\%Pu" type

\$im $=960, x_{e}-1, \operatorname{sm}=3$

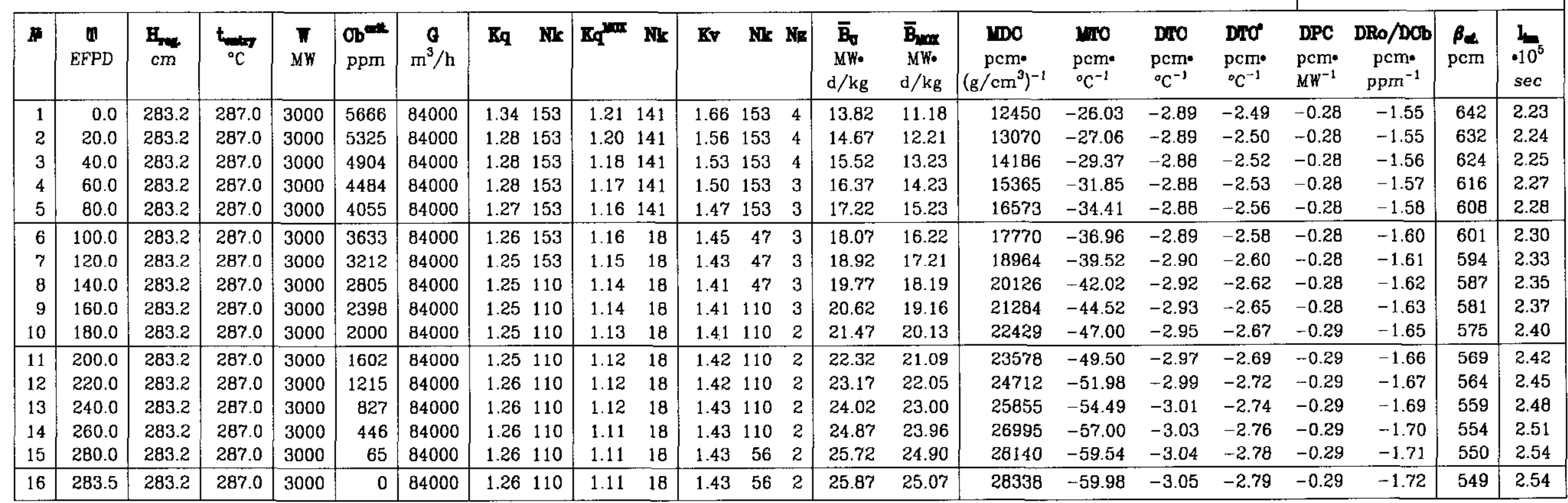


Table 4.10. Main neutronics parameters in zero power states. Second cycle with 3 MOX LTAs of "100\%Pu" type

\begin{tabular}{|c|c|c|c|c|c|c|c|c|c|c|c|c|c|}
\hline $\mathbf{T}$ & $\begin{array}{l}\text { RO } \\
\text { pem }\end{array}$ & $\begin{array}{c}\text { Cb } \\
\text { ppm }\end{array}$ & Bank 10 & $\begin{array}{c}\text { Other } \\
\text { banks } \downarrow \uparrow\end{array}$ & $\mathbf{X e}$ & Sm & $\underset{{ }^{\circ} \mathrm{C}}{\text { Tmod }}$ & $\begin{array}{c}\text { MTC } \\
\mathrm{pem} /{ }^{\circ} \mathrm{C}\end{array}$ & $\begin{array}{c}\mathrm{MDC} \\
\mathrm{pcm} / \mathrm{g} / \mathrm{cc}\end{array}$ & $\begin{array}{c}\text { DTC } \\
\mathrm{pem} /{ }^{\circ} \mathrm{C}\end{array}$ & $\begin{array}{l}\text { DRO/DCB } \\
\mathrm{pcm} / \mathrm{ppm}\end{array}$ & $\begin{array}{r}\lambda \mathrm{m} \\
* 10^{5} \mathrm{~s}\end{array}$ & $\begin{array}{l}\text { Beff } \\
{ }^{*} 100\end{array}$ \\
\hline BOC & 0 & 8800 & $100 \% \uparrow$ & $100 \% \uparrow$ & 0 & Smh & 280 & -1.87 & 2710 & -2.97 & -1.49 & 2.10 & 0.64 \\
\hline EOC & 0 & 1950 & $100 \% \uparrow$ & $100 \% \uparrow$ & eq & Sm eq & 280 & -27.81 & 18930 & -3.31 & -1.77 & 2.44 & 0.56 \\
\hline BOC & $\begin{array}{c}-14110 \\
\left(\text { RO }_{\text {STOP }}\right)\end{array}$ & 16000 & $100 \% \uparrow$ & $100 \% \uparrow$ & 0 & Smh & 20 & & & & & & \\
\hline
\end{tabular}


Table 4.11. Evolution of main neutronics parameters. 3-d cycle with 3 MOX LTAs of "100\%Pu" type

$\operatorname{Sim}=360, X e=1, S m=3$

\begin{tabular}{|c|c|c|c|c|c|c|c|c|c|c|c|c|c|c|c|c|c|c|c|c|c|c|c|}
\hline$\mu$ & $\begin{array}{c}\mathrm{T} \\
\text { EFPD }\end{array}$ & $\begin{array}{c}\mathrm{H}_{\mathrm{res}} \\
\mathrm{cm}\end{array}$ & $t_{\text {entry }}$ & $\begin{array}{c}W \\
M W\end{array}$ & $\begin{array}{l}\mathrm{Cb}^{\mathrm{Er} \mathrm{L}} \\
\mathrm{ppm}\end{array}$ & $\begin{array}{c}\mathrm{G} \\
\mathrm{m}^{3} / \mathrm{h}\end{array}$ & $\mathbf{K q}$ & Nk & $\mathrm{Kq}^{\operatorname{mox}}$ & Nk & Kv & Nk & $\mathrm{Nz}_{\mathbf{z}}$ & $\begin{array}{c}\overline{\mathrm{B}}_{\mathrm{U}} \\
\mathrm{MW} \\
\mathrm{d} / \mathrm{kg}\end{array}$ & $\begin{array}{l}\overline{\mathrm{B}}_{\operatorname{yox}} \\
M W \bullet \\
\mathrm{d} / \mathrm{kg}\end{array}$ & $\begin{array}{c}\text { MDC } \\
\text { pcm・ } \\
\left(\mathrm{g} / \mathrm{cm}^{3}\right)^{-1}\end{array}$ & $\begin{array}{l}\text { MTC } \\
\text { pcm } \\
{ }^{\circ} \mathrm{C}^{-1}\end{array}$ & $\begin{array}{l}\text { DTC } \\
\text { pcm• } \\
{ }^{\circ} \mathrm{C}^{-1}\end{array}$ & $\begin{array}{l}\text { DTC } \\
\text { pcm* } \\
{ }^{\circ} \mathrm{C}^{-1}\end{array}$ & $\begin{array}{l}\mathrm{DPC} \\
\mathrm{pcm} \cdot \\
\mathrm{MW}^{-1}\end{array}$ & $\begin{array}{c}\mathrm{DRo} / \mathrm{DCb} \\
\mathrm{pcm} \\
\mathrm{ppm}^{-1}\end{array}$ & $\begin{array}{c}\boldsymbol{\beta}_{\mathrm{ef}} \\
\text { pcm }\end{array}$ & $\begin{array}{l}\mathrm{l}_{\mathrm{gm}} \\
\cdot 10^{5} \\
\mathrm{sec}\end{array}$ \\
\hline 1 & 0.0 & z & .0 & 00 & 0 & 000 & 3 & 126 & 4 & 111 & 64 & 126 & 4 & .36 & 67 & 1897 & -24.77 & -2.89 & -2.48 & -0.28 & 1.55 & 47 & 2.23 \\
\hline 2 & 20.0 & 28 & 287.0 & 3000 & 5472 & 84000 & 1.28 & 11 & & 111 & 1.54 & 126 & 4 & & & & 9 & 8 & 9 & & & 636 & 2.24 \\
\hline 3 & 40.0 & 283.2 & 287.0 & 3000 & 5054 & 84000 & 1.28 & 11 & 1.05 & 111 & 1.51 & 11 & 4 & 6 & 26.86 & 13685 & 81 & -2.88 & & & & 628 & 2.25 \\
\hline 4 & 60.0 & 283.2 & 287.0 & 3000 & 4629 & 84000 & 1.27 & 11 & 1.05 & 111 & 1.48 & 126 & 3 & 5.91 & 27.75 & 14883 & 74 & -2.87 & & & & 620 & 2.27 \\
\hline 5 & 80.0 & 283.2 & 287.0 & 3000 & 4204 & 84000 & 1.26 & 11 & 1.04 & 111 & 1.46 & 126 & 3 & 6.76 & 8.64 & 16095 & 31 & -2.88 & -2.55 & & & 612 & 2.28 \\
\hline 6 & 100.0 & 283.2 & 287.0 & 3000 & 3779 & 84000 & 1.25 & 124 & 1.04 & 111 & 1.44 & 124 & 3 & & & & & & 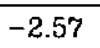 & & & 604 & 2.30 \\
\hline 7 & 120.0 & 283.2 & 287.0 & 3000 & 3368 & 84000 & 1.25 & 124 & 1.04 & 111 & 1.44 & 124 & 3 & 18.47 & 30.42 & 86 & 42 & -2 & & & & 7 & 32 \\
\hline 8 & 140.0 & 283.2 & 287.0 & 3000 & 2958 & 84000 & 1.25 & 124 & 1.04 & 111 & 1.43 & 124 & 3 & 9.32 & 1.30 & 19661 & -40 & -2.91 & -2.62 & 28 & & 591 & 2.34 \\
\hline 9 & 160.0 & 283.2 & 287.0 & 3000 & 2547 & 84000 & 1.25 & 124 & 1.04 & 111 & 1.42 & 124 & 3 & 20.17 & 2.18 & 20833 & -43.48 & -2.93 & -2.64 & & & 584 & 2.37 \\
\hline 10 & 180.0 & 283.2 & 287.0 & 3000 & 2150 & 84000 & 1.25 & 124 & 1.04 & 111 & 1.42 & 124 & 2 & 21.02 & 33.07 & 21979 & -45.97 & -2.95 & -2.67 & -0.29 & -1.64 & 578 & 2.39 \\
\hline 11 & 200.0 & 283.2 & 287.0 & 3000 & 1754 & 84000 & 1.25 & 134 & 1.04 & 111 & 1.42 & 124 & 2 & 21.88 & 33.95 & 23129 & -48.47 & -2.97 & -2.69 & -0.29 & \begin{tabular}{l|}
-1.66 \\
\end{tabular} & 572 & 2.42 \\
\hline 12 & 220.0 & 283.2 & 287.0 & 3000 & 1357 & 84000 & 1.25 & 134 & 1.04 & 111 & 1.42 & 124 & 2 & 22.73 & 34.83 & 24284 & -5 & -2.99 & -2 & -0.29 & -1.67 & 567 & 2.45 \\
\hline 13 & 240.0 & 283.2 & 287.0 & 3000 & 974 & 84000 & 1.25 & 134 & 1.04 & 111 & 1.42 & 124 & 2 & 23.58 & 35.72 & 25422 & -53.50 & & & & & 561 & 2.47 \\
\hline 14 & 260.0 & 283.2 & 287.0 & 3000 & 591 & 84000 & 1.25 & 134 & 1.04 & 111 & 1.42 & 134 & 2 & 24.43 & 36.60 & 26568 & -56.03 & -3.02 & & & 70 & 557 & 2.50 \\
\hline 15 & 280.0 & 283.2 & 287.0 & 3000 & 208 & 84000 & 1.25 & 134 & 1.04 & 111 & 1.42 & 134 & 2 & 25.28 & 37.49 & 27720 & -58.58 & -3.04 & -2.78 & -0.29 & -1.71 & 552 & 2.53 \\
\hline 16 & 291.0 & 283.2 & 287.0 & 3000 & 0 & 84000 & 1.25 & 134 & 1.04 & 111 & 1.42 & 134 & 2 & 25.75 & 37.97 & 28351 & -59.99 & -3.05 & -2.79 & -0.29 & -1.72 & 550 & 2.55 \\
\hline
\end{tabular}


Table 4.12. Main neutronics parameters in zero power states. Third cycle with 3 MOX LTAs of "100\%Pu" type

\begin{tabular}{|c|c|c|c|c|c|c|c|c|c|c|c|c|c|}
\hline$T$ & $\begin{array}{l}\text { RO } \\
\text { pcm }\end{array}$ & $\begin{array}{c}\mathrm{Cb} \\
\mathrm{ppm}\end{array}$ & Bank 10 & $\begin{array}{c}\text { Other } \\
\text { banks } \downarrow \uparrow\end{array}$ & $\overline{\mathrm{Xe}}$ & Sm & $\begin{array}{c}\text { Tmod } \\
{ }^{\circ} \mathrm{C}\end{array}$ & $\begin{array}{c}\text { MTC } \\
\text { pem } /{ }^{\circ} \mathrm{C}\end{array}$ & $\begin{array}{c}\mathrm{MDC} \\
\mathrm{pem} / \mathrm{g} / \mathrm{cc}\end{array}$ & $\begin{array}{c}\text { DTC } \\
\text { pem/ } /{ }^{\circ} \mathrm{C}\end{array}$ & $\begin{array}{l}\text { DRO/DCB } \\
\mathrm{pcm} / \mathrm{ppm}\end{array}$ & $\begin{array}{r}\lambda \mathrm{m} \\
* 10^{5} \mathrm{~s}\end{array}$ & $\begin{array}{l}\text { Beff } \\
\text { pem }\end{array}$ \\
\hline$\overline{\mathrm{BOC}}$ & 0 & 8830 & $100 \% \uparrow$ & $100 \% \uparrow$ & 0 & Smh & 280 & -0.94 & 2170 & -2.96 & -1.49 & 2.10 & 650 \\
\hline$\overline{\text { EOC }}$ & 0 & 1950 & $100 \% \uparrow$ & $100 \% \uparrow$ & eq & Sm eq & 280 & -27.87 & 18960 & -3.31 & -1.77 & 2.44 & 560 \\
\hline$\overline{B O C}$ & $\begin{array}{c}-14107 \\
\left(\mathrm{RO}_{\text {STOP }}\right)\end{array}$ & 16000 & $100 \% \uparrow$ & $100 \% \uparrow$ & 0 & $\overline{\text { Smh }}$ & 20 & & & & & & \\
\hline
\end{tabular}


Table 4.13. Pin Power Peaking Factors Attained During Fuel Cycle

\begin{tabular}{|c|c|c|c|c|c|c|c|c|c|c|c|c|c|c|c|c|c|c|c|c|c|c|c|}
\hline \multirow{3}{*}{$\begin{array}{c}\mathbf{T} \\
\text { EFPD }\end{array}$} & \multicolumn{7}{|c|}{$\mathbf{K r}$} & \multicolumn{4}{|c|}{$\mathbf{N}(\mathrm{Kr})$} & \multicolumn{4}{|c|}{ Ko-total } & \multicolumn{4}{|c|}{$\mathbf{N}$ (Ko-total) } & \multicolumn{4}{|c|}{ M(Ko-total) } \\
\hline & UOX & \multicolumn{2}{|c|}{$\begin{array}{c}\text { MOX } \\
1\end{array}$} & \multicolumn{2}{|c|}{$\begin{array}{c}\mathrm{MOX} \\
2\end{array}$} & \multicolumn{2}{|c|}{$\begin{array}{c}\mathrm{MOX} \\
3\end{array}$} & \multirow[t]{2}{*}{ UOX } & \multirow[t]{2}{*}{$\underset{1}{\mathrm{MOX}}$} & \multirow[t]{2}{*}{$\underset{2}{\mathrm{MOX}}$} & \multirow[t]{2}{*}{$\begin{array}{c}\text { MOX } \\
3\end{array}$} & \multirow{2}{*}{$\begin{array}{c}\text { UOX } \\
\\
\text { ALL } \\
\text { CORE } \\
\end{array}$} & \multirow{2}{*}{$\begin{array}{c}\text { MOX } \\
1 \\
\\
\text { ALL } \\
\text { CORE } \\
\end{array}$} & \multirow{2}{*}{$\begin{array}{c}\text { MOX } \\
2 \\
\\
\text { COL } \\
\text { CORE } \\
\end{array}$} & \multirow{2}{*}{$\begin{array}{c}\text { MOX } \\
3 \\
\\
\text { ALL } \\
\text { CORE } \\
\end{array}$} & \multirow[t]{2}{*}{ UOX } & \multirow[t]{2}{*}{$\begin{array}{c}\mathrm{MOX} \\
1\end{array}$} & \multirow[t]{2}{*}{$\begin{array}{c}\mathrm{MOX} \\
2\end{array}$} & \multirow[t]{2}{*}{$\begin{array}{c}\mathrm{MOX} \\
3\end{array}$} & \multirow{2}{*}{$\begin{array}{l}\mathrm{U} \\
\mathrm{O} \\
\mathrm{X}\end{array}$} & \multirow{2}{*}{$\begin{array}{l}M \\
0 \\
X \\
1\end{array}$} & \multirow{2}{*}{$\begin{array}{l}\mathrm{M} \\
\mathrm{O} \\
\mathrm{X} \\
2\end{array}$} & \multirow{2}{*}{\begin{tabular}{|l|}
$\mathrm{M}$ \\
$\mathrm{O}$ \\
$\mathrm{X}$ \\
3 \\
\end{tabular}} \\
\hline & $\begin{array}{c}\text { ALL } \\
\text { CORE }\end{array}$ & $\begin{array}{l}\text { AI.I. } \\
\text { CORE }\end{array}$ & $\begin{array}{c}\text { MOX } \\
\text { FA }\end{array}$ & $\begin{array}{l}\text { ALL } \\
\text { CORE }\end{array}$ & $\begin{array}{c}\text { MOX } \\
\text { FA }\end{array}$ & $\begin{array}{c}\text { ALL } \\
\text { CORE }\end{array}$ & $\begin{array}{c}\mathrm{MOX} \\
\mathrm{FA}\end{array}$ & & & & & & & & & & & & & & & & \\
\hline 0 & 1.51 & 1.47 & 1.28 & 1.49 & 1.37 & 1.48 & 1.25 & 19 & 38 & 153 & 126 & 1.86 & 1.79 & 1.85 & 1.83 & 19 & 38 & 153 & 126 & 4 & 4 & 4 & 4 \\
\hline 20 & 1.49 & 1.40 & 1.22 & 1.43 & 1.36 & 1.42 & 1.27 & 19 & 38 & 110 & 126 & 1.80 & 1.68 & 1.72 & 1.71 & 19 & 38 & 153 & 126 & 4 & 4 & 4 & 4 \\
\hline 40 & 1.48 & 1.40 & 1.19 & 1.41 & 1.34 & 1.41 & 1.25 & 19 & 40 & 110 & 126 & 1.76 & 1.65 & 1.68 & 1.67 & 19 & 38 & 153 & 126 & 4 & 4 & 4 & 4 \\
\hline 60 & 1.47 & 1.39 & 1.16 & 1.40 & 1.33 & 1.39 & 1.25 & 19 & 92 & 153 & 126 & 1.72 & 1.62 & 1.64 & 1.63 & 19 & 117 & 153 & 126 & 3 & 3 & 3 & 3 \\
\hline 80 & 1.45 & 1.39 & 1.15 & 1.39 & 1.32 & 1.38 & 1.23 & 19 & 32 & 153 & 117 & 1.69 & 1.60 & 1.61 & 1.60 & 19 & 92 & 153 & 137 & 3 & 3 & 3 & 3 \\
\hline 100 & 1.44 & 1.38 & 1.14 & 1.38 & 1.31 & 1.37 & 1.23 & 19 & 32 & 153 & 126 & 1.66 & 1.58 & 1.59 & 1.57 & 19 & 32 & 153 & 12 & 3 & 3 & 3 & 3 \\
\hline 120 & 1.43 & 1.37 & 1.14 & 1.37 & 1.30 & 1.36 & 1.22 & 19 & 32 & 153 & 126 & 1.64 & 1.57 & 1.57 & 1.55 & 19 & 32 & 47 & 12 & 3 & 3 & 3 & 3 \\
\hline 140 & 1.42 & 1.37 & 1.13 & 1.36 & 1.29 & 1.35 & 1.22 & 19 & 32 & 153 & 126 & 1.62 & 1.56 & 1.55 & 1.53 & 19 & 124 & 126 & 137 & 3 & 3 & 3 & 3 \\
\hline 160 & 1.41 & 1.36 & 1.13 & 1.35 & 1.29 & 1.34 & 1.21 & 19 & 124 & 126 & 126 & 1.60 & 1.55 & 1.53 & 1.52 & 19 & 124 & 35 & 137 & 3 & 3 & 3 & 3 \\
\hline 180 & 1.39 & 1.36 & 1.12 & 1.35 & 1.28 & 1.33 & 1.21 & 19 & 124 & 126 & 126 & 1.58 & 1.54 & 1.51 & 1.50 & 19 & 124 & 126 & 137 & 3 & 2 & 2 & 3 \\
\hline 200 & 1.38 & 1.35 & 1.11 & 1.34 & 1.27 & 1.32 & 1.21 & 19 & 124 & 126 & 126 & 1.57 & 1.54 & 1.51 & 1.49 & 19 & 124 & 110 & 124 & 2 & 2 & 2 & 2 \\
\hline 220 & 1.37 & 1.35 & 1.10 & 1.33 & 1.26 & 1.32 & 1.20 & 19 & 124 & 126 & 137 & 1.56 & 1.54 & 1.50 & 1.48 & 19 & 124 & 110 & 124 & 2 & 2 & 2 & 2 \\
\hline 240 & 1.36 & 1.34 & 1.10 & 1.32 & 1.26 & 1.31 & 1.20 & 19 & 124 & 110 & 137 & 1.55 & 1.53 & 1.50 & 1.48 & 19 & 124 & 110 & 124 & 2 & 2 & 2 & 2 \\
\hline 260 & 1.35 & 1.34 & 1.10 & 1.31 & 1.25 & 1.30 & 1.19 & 19 & 124 & 110 & 137 & 1.54 & 1.53 & 1.49 & 1.47 & 19 & 124 & 110 & 134 & 2 & 2 & 2 & 2 \\
\hline 280 & 1.34 & 1.33 & 1.10 & 1.31 & 1.25 & 1.29 & 1.19 & 6 & 124 & 110 & 154 & 1.53 & 1.52 & 1.49 & 1.47 & 19 & 124 & 56 & 134 & 2 & 2 & 2 & 2 \\
\hline EOC & 1.34 & 1.33 & 1.10 & 1.31 & 1.25 & 1.29 & 1.19 & 6 & 124 & 110 & 152 & 1.52 & 1.52 & 1.49 & 1.46 & 19 & 124 & 56 & 134 & 2 & 2 & 2 & 2 \\
\hline
\end{tabular}


Table 4.14. Core Subcriticality (Scram Margin) in different states in the process of Scram actuation

\begin{tabular}{|c|c|c|c|c|c|c|c|c|c|c|c|c|c|}
\hline \multicolumn{6}{|c|}{ State parameters } & \multicolumn{8}{|c|}{ RO, pcm } \\
\hline \multirow{2}{*}{ 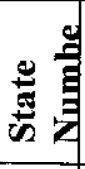 } & \multirow{2}{*}{$\sum_{3}^{3}$} & \multirow{2}{*}{$\begin{array}{l}0 \\
0 \\
0 \\
0\end{array}$} & \multirow[t]{2}{*}{$\stackrel{00}{20}$} & \multirow{2}{*}{ 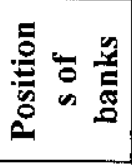 } & \multirow{2}{*}{ 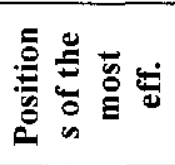 } & \multicolumn{2}{|c|}{ UOX } & \multicolumn{2}{|c|}{$\begin{array}{c}\text { MOX } \\
\text { 1er } \\
\text { cycle }\end{array}$} & \multicolumn{2}{|c|}{$\begin{array}{l}\text { MOX } \\
\text { 2nd } \\
\text { cycle }\end{array}$} & \multicolumn{2}{|c|}{$\begin{array}{c}\text { MOX } \\
\text { 3d } \\
\text { cycle }\end{array}$} \\
\hline & & & & & & BOC & EOC & BOC & EOC & BOC & EOC & BOC & EOC \\
\hline \multirow[t]{2}{*}{1} & 3000 & Nominal. & 100 & 100 & 100 & +522 & +605 & +483 & +600 & +434 & +563 & +449 & +569 \\
\hline & \multicolumn{13}{|c|}{ Regulation margin of reactivity } \\
\hline \multirow[t]{2}{*}{2.} & 3000 & Nominal. & 50 & 100 & 100 & 0. & 0. & 0. & 0. & 0 . & 0. & 0. & 0. \\
\hline & \multirow{2}{*}{\multicolumn{13}{|c|}{$\begin{array}{l}\text { Seram actuation without sticking of the most effective CR } \\
\begin{array}{l|c|c|c|c}3000 & \text { Nominal. } & 0 & 0 & 0\end{array}\end{array}$}} \\
\hline \multirow[t]{2}{*}{3} & & & & & 0 & -8833 & -9136 & -8772 & -9043 & -8806 & -9064 & -8994 & -9150 \\
\hline & \multicolumn{13}{|c|}{ Scram actuation with sticking of the most effective CR } \\
\hline \multirow[t]{2}{*}{4} & 3000 & Nominal. & 0 & 0 & 100 & -7970 & -8262 & -7964 & -8178 & -7889 & -8153 & -8671 & -8282 \\
\hline & \multicolumn{13}{|c|}{ Doppler effect } \\
\hline \multirow[t]{2}{*}{5} & 0 & Nominal. & 0 & 0 & 100 & -6391 & -6807 & -6989 & -7296 & -6865 & -7244 & -7628 & -7379 \\
\hline & \multicolumn{13}{|c|}{ Moderator temperature effect } \\
\hline \multirow[t]{2}{*}{6} & 0 & 287 & 0 & 0 & 100 & -5550 & -5088 & -5718 & -5001 & -5609 & -5000 & -6488 & -5192 \\
\hline & \multicolumn{13}{|c|}{ Moderator temperature effect } \\
\hline \multirow[t]{2}{*}{7} & 0 & 280 & 0 & 0 & 100 & -5358 & -4711 & -5530 & -4624 & -5417 & -4624 & -6294 & -4817 \\
\hline & \multicolumn{13}{|c|}{ Vapor effect $(\Delta p-50 \mathrm{pcm})$} \\
\hline \multirow[t]{2}{*}{8} & 0 & 280 & 0 & 0 & 100 & -5308 & -4661 & -5480 & -4574 & -5367 & -4574 & -6244 & -4767 \\
\hline & \multicolumn{13}{|c|}{ Uncertainty of $(\mathrm{RO})_{A P}$ calculation $(10 \%$ of $\mathrm{p} 4)$} \\
\hline \multirow[t]{2}{*}{9} & 0 & 280 & 0 & 0 & 100 & -4511 & -3835 & -4684 & -3756 & -4578 & -3759 & -5377 & -3939 \\
\hline & \multicolumn{13}{|c|}{ Uncertainty of temperature effect calculation $(\Delta \rho-180 \mathrm{pem})$} \\
\hline 10 & 0 & 280 & 0 & 0 & 100 & -4331 & -3655 & -4504 & -3576 & -4398 & -3579 & -5197 & -3759 \\
\hline & Absorb & Irradiatio & ffect ( & $100 \mathrm{pcm}$ & & & & & & & & & \\
\hline 11 & 0 & 280 & 0 & 0 & 100 & -4231 & -3555 & -4404 & -3476 & -4298 & -3479 & -5097 & -3659 \\
\hline
\end{tabular}


Table 4.15a. Control rods worth calculation. States description

\begin{tabular}{|c|c|c|c|c|c|}
\hline V1. BOC & V2. $\mathrm{BOC}$ & V3. BOC & V1. EOC & V1. EOC & V1. EOC \\
\hline S1 & S1 & S1 & S1 & S1 & S1 \\
\hline Wnom, & MCL, & $\mathrm{MCL}$ & Wnom, & MCL, & MCL, \\
\hline $\mathrm{Xe}=\mathrm{Xe}$ eq, & $\mathrm{Xe}=0$ & $\mathrm{Xe}=\mathrm{Xe} \mathrm{eq}$, & $\mathrm{Xe}=\mathrm{Xe}$ eq, & $\mathrm{Xe}=\mathrm{Xe} \mathrm{eq}$ & $\mathrm{Xe}=0$, \\
\hline $\begin{array}{l}\mathrm{t}_{\text {entry }}=287^{\circ} \mathrm{C} \text {, } \\
\mathrm{Cb} \text { bumup }\end{array}$ & $\begin{array}{c}\mathrm{t}_{\text {entry }}=280^{\circ} \mathrm{C} \\
\mathrm{Cb} \text { crit }\end{array}$ & $\begin{array}{c}t_{\text {entry }}=280^{\circ} \mathrm{C} \\
\text { Cb crit }\end{array}$ & $\begin{array}{l}t_{\text {cnlry }}=287^{\circ} \mathrm{C} \\
\mathrm{Cb} \text { burnup }\end{array}$ & $\begin{array}{c}t_{\text {entry }}=280^{\circ} \mathrm{C} \\
\text { Cb crit }\end{array}$ & $\begin{array}{c}\mathrm{t}_{\text {euty }}=280^{\circ} \mathrm{C} \\
\mathrm{Cb} \text { crit }\end{array}$ \\
\hline $\begin{array}{c}100 \% 5 \downarrow^{*} \\
30 \% 10 \downarrow\end{array}$ & $30 \% 10 \downarrow$ & $30 \% 10 \downarrow$ & $\begin{array}{c}100 \% 5 \downarrow \\
30 \% 10 \downarrow\end{array}$ & $\begin{array}{c}100 \% 5 \downarrow \\
30 \% 10 \downarrow\end{array}$ & $\begin{array}{c}100 \% 5 \downarrow \\
30 \% 10 \downarrow\end{array}$ \\
\hline S2: the same & S2: the same & S2: the same & S2: the same & S2: the same & S2: the same \\
\hline $\begin{array}{c}\text { but } \\
100 \% \ln 10 \downarrow\end{array}$ & $\begin{array}{l}\text { but } \\
100 \%+10 \downarrow\end{array}$ & $\begin{array}{c}\text { but } \\
100^{\circ} 1-10 \downarrow\end{array}$ & $\begin{array}{c}\text { but } \\
100 \% 1-10 \downarrow\end{array}$ & $\begin{array}{c}\text { but } \\
100 \% 1-10 \downarrow\end{array}$ & $\begin{array}{c}\text { but } \\
\text { s. }\end{array}$ \\
\hline & $100 \% 1-10 \downarrow$ & $100 \% 1-10 \downarrow$ & $100 \% 1-10 \downarrow$ & $100 \% 1-10 \downarrow$ & $100 \% 1-10 \downarrow$ \\
\hline
\end{tabular}

Table 4.15b. Control rods worth in Uranium reference core and in 3 MOX LTAs loaded cores (pcm)

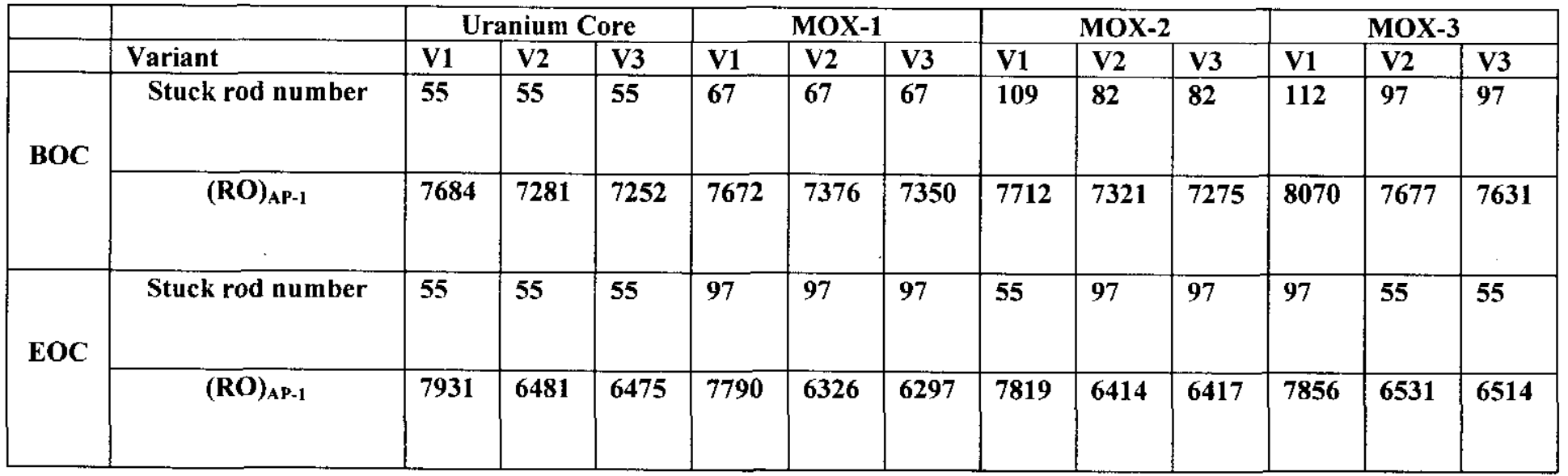

\footnotetext{
" $\mathrm{X} \% \mathrm{~N} \downarrow$ means that the Bank $\mathrm{N}$ is $\mathrm{X} \%$ inserted in core
} 
Table 4.16. Core reactivity in the process of control rods movement

\begin{tabular}{|c|c|c|c|c|c|c|c|c|}
\hline \multirow{3}{*}{$\begin{array}{c}\text { AP } \\
\text { Position, } \% \\
\text { (Hreg=80\%) }\end{array}$} & \multicolumn{8}{|c|}{$B O C$} \\
\hline & \multicolumn{2}{|c|}{ Uranium } & \multicolumn{2}{|c|}{ MOX-1 } & \multicolumn{2}{|c|}{ MOX-2 } & \multicolumn{2}{|c|}{ MOX-3 } \\
\hline & No stuck & $\begin{array}{c}\text { Stuck } \\
\text { N } 55\end{array}$ & No stuck & $\begin{array}{c}\text { Stuck } \\
\text { N } 67\end{array}$ & $\begin{array}{l}\text { No } \\
\text { stuck }\end{array}$ & $\begin{array}{l}\text { Stuck } \\
\text { N } 109\end{array}$ & $\begin{array}{c}\text { No } \\
\text { stuck }\end{array}$ & $\begin{array}{l}\text { Stuck } \\
\text { N } 112\end{array}$ \\
\hline 100 & 0 & 0 & 0 & 0 & $\overline{0}$ & $\overline{0}$ & $\overline{0}$ & 0 \\
\hline 90 & -120 & -120 & -120 & -120 & -110 & -110 & -120 & -120 \\
\hline 80 & -210 & -210 & -210 & -210 & -200 & -200 & -200 & -200 \\
\hline 70 & -310 & -310 & -310 & -310 & -290 & -290 & -300 & -300 \\
\hline 60 & -460 & -460 & -450 & -450 & -430 & -430 & -440 & -440 \\
\hline 50 & -700 & -700 & -680 & -680 & -660 & -660 & -680 & -680 \\
\hline 40 & -1150 & -1140 & -1110 & -1100 & -1070 & -1070 & -1090 & -1090 \\
\hline 30 & -2000 & -1990 & -1920 & -1910 & -1860 & -1850 & -1900 & -1900 \\
\hline 20 & -3620 & -3590 & -3490 & -3470 & -3430 & -3400 & -3480 & -3480 \\
\hline 10 & -7050 & -6810 & -6930 & -6730 & -6900 & -6660 & -7010 & -7010 \\
\hline 0 & -9150 & -8330 & -9060 & -8300 & -9060 & -8180 & -9250 & -9250 \\
\hline
\end{tabular}

\begin{tabular}{|c|c|c|c|c|c|c|c|c|}
\hline \multirow{3}{*}{$\begin{array}{c}\text { AP } \\
\text { Position, \% } \\
\text { (Hreg=80\%) }\end{array}$} & \multicolumn{8}{|c|}{ EOC } \\
\hline & \multicolumn{2}{|c|}{ Uranium } & \multicolumn{2}{|c|}{ MOX-1 } & \multicolumn{2}{|c|}{ MOX-2 } & \multicolumn{2}{|c|}{ MOX-3 } \\
\hline & No stuck & $\begin{array}{c}\text { Stuck } \\
\text { N } 55\end{array}$ & No stuck & $\begin{array}{c}\text { Stuck } \\
\text { N } 97\end{array}$ & $\begin{array}{c}\text { No } \\
\text { stuck }\end{array}$ & $\begin{array}{l}\text { Stuck } \\
\text { N } 97\end{array}$ & $\begin{array}{c}\text { No } \\
\text { stuck }\end{array}$ & $\begin{array}{l}\text { Stuck } \\
\text { N } 97\end{array}$ \\
\hline 100 & 0 & 0 & 0 & 0 & 0 & 0 & 0 & 0 \\
\hline 90 & -140 & -140 & -140 & -140 & -130 & -130 & -140 & -140 \\
\hline 80 & -190 & -190 & -190 & -190 & -190 & -190 & -190 & -190 \\
\hline 70 & -260 & -260 & -260 & -260 & -250 & -250 & -260 & -260 \\
\hline 60 & -360 & -360 & -360 & -360 & -350 & -350 & -350 & -350 \\
\hline 50 & -530 & -530 & -530 & -530 & -520 & -520 & -530 & -530 \\
\hline 40 & -880 & -870 & -870 & -870 & -850 & -850 & -860 & -860 \\
\hline 30 & -1590 & -1580 & -1570 & -1570 & -1540 & -1530 & -1540 & -1540 \\
\hline 20 & -3000 & -2980 & -2960 & -2960 & -2910 & -2890 & -2910 & -2890 \\
\hline 10 & -6300 & -6160 & -6200 & -6200 & -6180 & -6020 & -6190 & -6060 \\
\hline 0 & -9410 & -8570 & -9310 & -9310 & -9310 & -8430 & -9400 & -8560 \\
\hline
\end{tabular}




\section{ש}

Design Studies of "100\%Pu" MOX Lead Test Assembly (Report for FY99)

Table 4.17. Return Criticality Temperature

\begin{tabular}{|c|c|c|c|c|}
\hline & UOX & MOX-1 & MOX-2 & MOX-3 \\
\hline RCT,${ }^{\circ} \mathrm{C}$ & 124 & 129 & 130 & 117 \\
\hline
\end{tabular}


Figure 2.1. Simplified Design for Uranium Reference Assembly

(Type A)

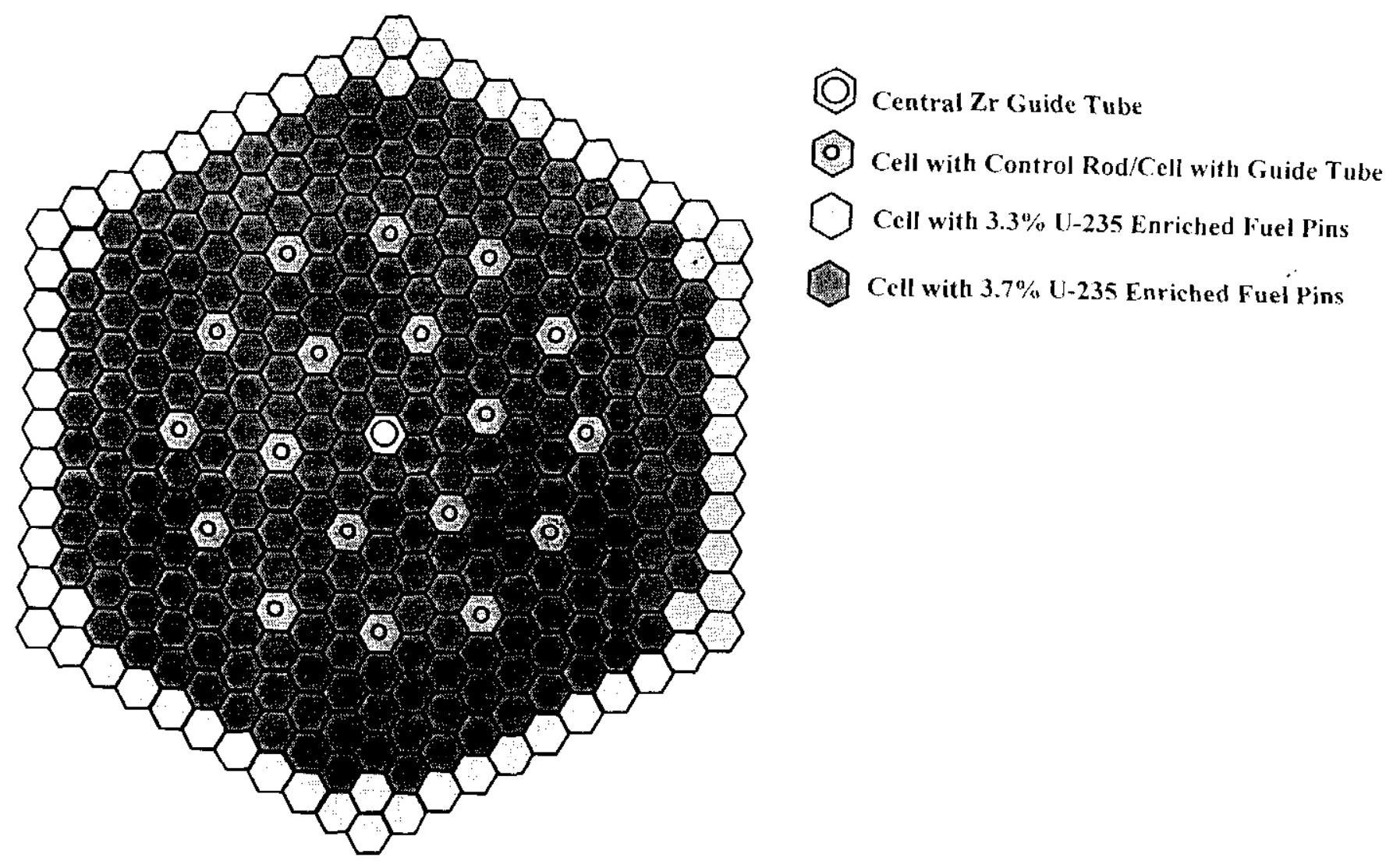

RRC KI. Design Studies of "100\%Pu" MOX Lead Test Assembly (Report for FY99) 
RUSSIAN RESEARCH CENTER KURCHATOV INSTITUTE

Design Studies of “100\%Pu” MOX Lead Test Assembly (Report for FY99)

Figure 2.2. Calculational Model for Reference Uranium Assembly Surrounded by Uranium Assemblies. $60^{\circ}$ Sector

\author{
26, \\ 71,25, \\ $71,71,25$, \\ $71,71,71,25$ \\ 71,71,71,71,25, \\ $71,71,71,71,71,25$, \\ $29,71,71,71,71,71,25$, \\ $71,71,71,71,71,71,71,25$, \\ $71,71,71,29,71,71,71,71,25$, \\ $71,29,71,71,71,71,71,71,71,25$, \\ 71,71,71,71,71,71,71,71,71,71,25, \\ $27,71,71,71,71,29,71,71,71,71,71,26$, \\ $71,71,71,29,71,71,71,71,71,71,71,25,64$, \\ 71,71,71,71,71,71,71,71,71,71,71,25,64,64, \\ $71,71,29,71,71,71,29,71,71,71,71,25,64,50,50$, \\ $71,71,71,71,71,71,71,71,71,71,71,25,64,50,50,50$, \\ $29,71,71,71,71,29,71,71,71,71,71,25,64,50,50,50,50$, \\ $71,71,71,29,71,71,71,71,71,71,71,25,64,50,50,50,50,29$, \\ $71,71,71,71,71,71,71,71,71,71,71,25,64,50,50,50,50,50,50$, \\ $71,71,71,71,71,71,71,71,71,71,71,25,64,50,5050,29,50,50,50$, \\ $71,71,71,71,71,71,71,71,71,71,71,25,64,50,50,50,50,50,50,50,50$, \\ $71,71,71,71,71,71,71,71,71,71,71,25,64,50,50,50,50,50,50,29,50,50$, \\ $26,25,25,25,25,25,25,25,25,25,25,26,64,64,50,50,50,29,50,50,50,50,27$, \\ 25 - side water cell \\ 26 - corner water cell \\ 27 - central tube cell \\ 29 - guide tube cell / burnable absorber \\ 50 - uranium $3.7 \%$ U-235 fuel rods \\ 64 - uranium 3.3\% U-235 fuel rods \\ 71 - uranium $3.7 \% \mathrm{U}-235$ fuel rods
}




\section{Figure 2.3. Simplified Design for Uranium Assembly}

(Types $\mathrm{B}$ and $\mathrm{Ba}$ )

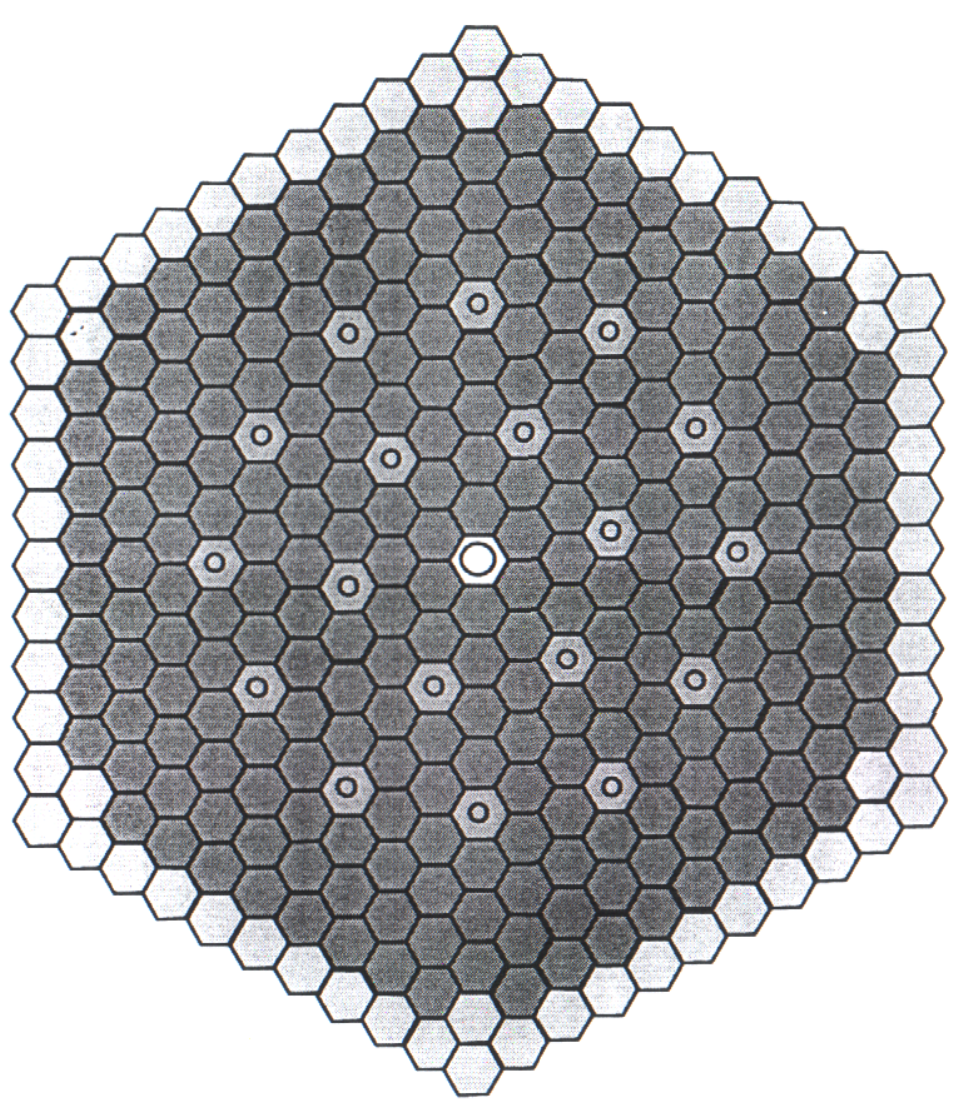

(0) Central Zr Guide Tube

0 Cell with Burnable Absorber/Cell with Guide Tube B: $\quad 0,065 \mathrm{~g} / \mathrm{cc}$ for Boron density Ba: $0,036 \mathrm{~g} / \mathrm{cc}$ for Boron density

Cell with $3.3 \%$ U-235 Enriched Fuel Pins

$\bigcirc$ Cell with $3.7 \%$ U-235 Enriched Fuel Pins 


\section{Figure 2.4. Simplified Design for Uranium Assembly}

\section{(Type C)}

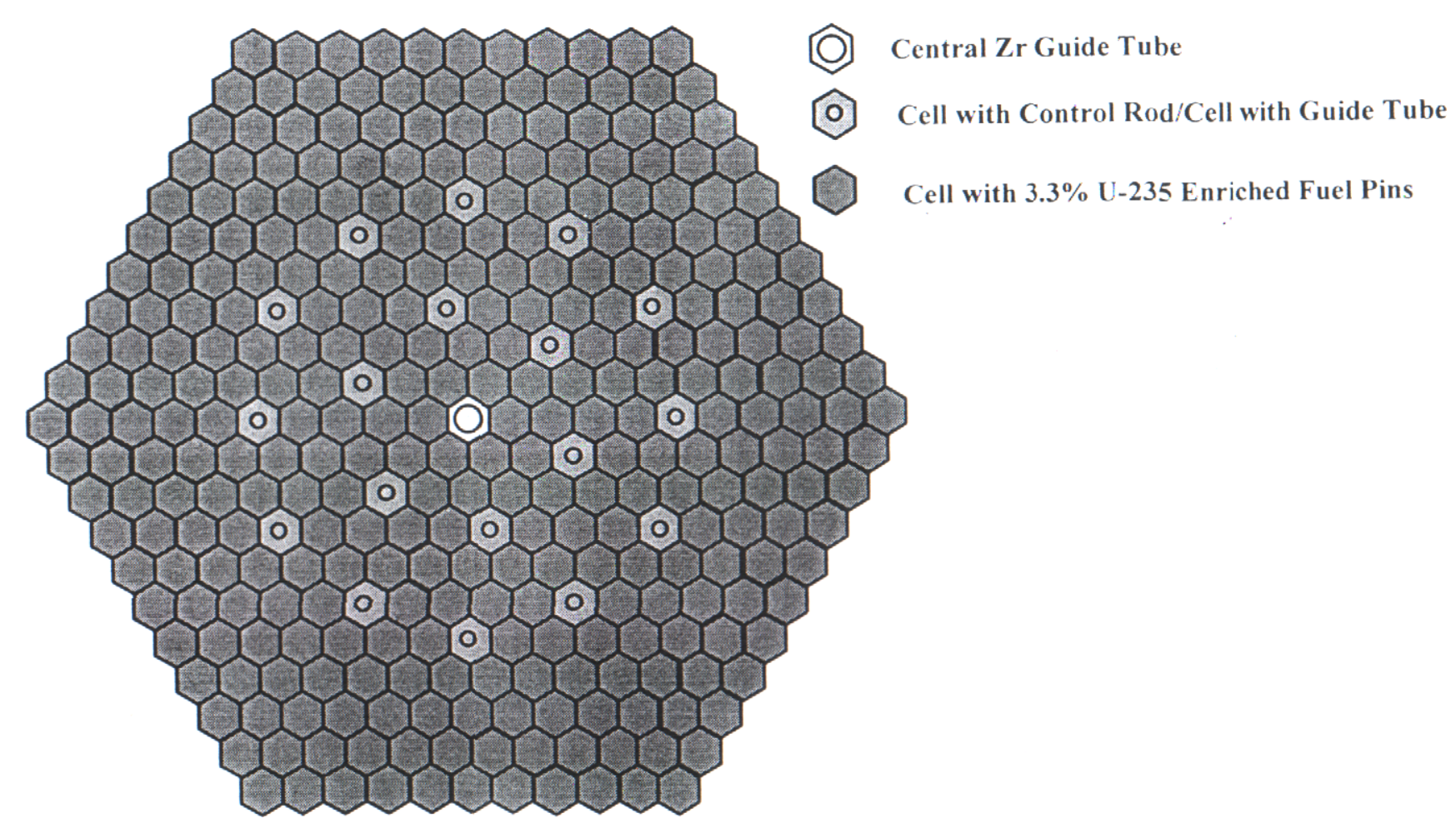

RRC KI. Design Studies of "100\%Pu” MOX Lead Test Assembly (Report for FY99) 
Figure 2.5. Simplified Design for $100 \%$ Plutonium (3 Zones) MOX LTA

$\bigcirc$ Guide Tube

$\bigcirc$ Central tube

$\bigcirc$ High Plutonium-Content MOX Rods

$\bigcirc$ Low Plutonium-Content MOX Rods

$\bigcirc$ Intermediate Plutonium-Content MOX Rods

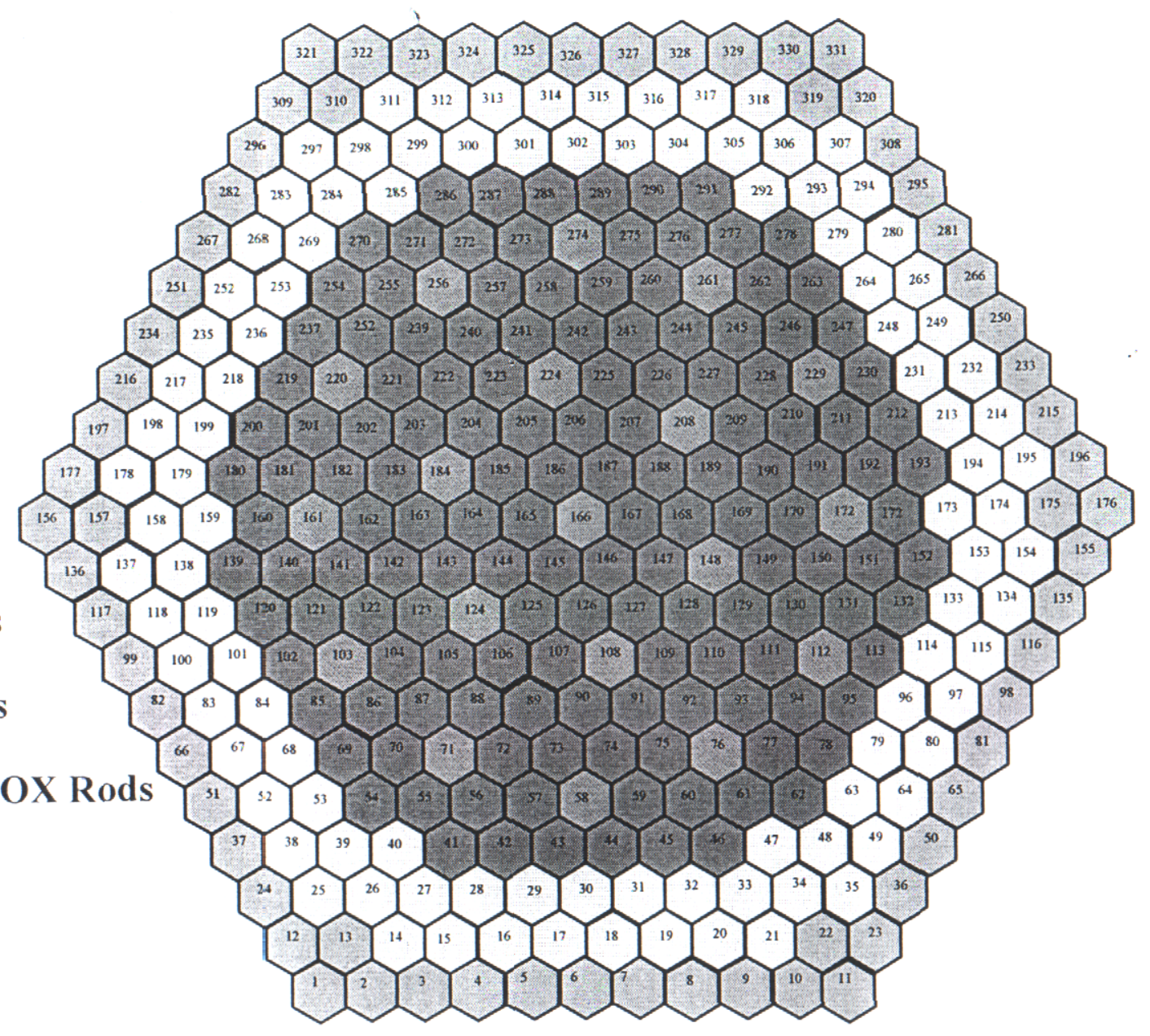

RRC KI. Design Studies of “100\%Pu” MOX Lead Test Assembly (Report for FY99) 
RUSSIAN RESEARCH CENTER KURCHATOV INSTITUTE

Design Studies of “100\%Pu” MOX Lead Test Assembly (Report for FY99)

Figure 2.6. Calculational Model for 3-Zones (100\% Plutonium) MOX LTA Surrounded by Uranium Assemblies. $60^{\circ}$ Sector

\author{
26 , \\ 71,25 , \\ $71,71,25$, \\ $71,71,71,25$, \\ $71,71,71,71,25$, \\ $71,71,71,71,71,25$, \\ $29,71,71,71,71,71,25$ \\ $71,71,71,71,71,71,71,25$, \\ $71,71,71,29,71,71,71,71,25$ \\ $71,29,71,71,71,71,71,71,71,25$, \\ $71,71,71,71,71,71,71,71,71,71,25$, \\ $27,71,71,71,71,29,71,71,71,71,71,26$, \\ $71,71,71,29,71,71,71,71,71,71,71,25,64$, \\ $71,71,71,71,71,71,71,71,71,71,71,25,64,64$, \\ $71,71,29,71,71,71,29,71,71,71,71,25,64$, \\ $71,71,71,71,71,71,71,71,71,71,71,25,64$, \\ $29,71,71,71,71,29,71,71,71,71,71,25,64, \quad 7,57,50,50$, \\ $71,71,71,29,71,71,71,71,71,71,71,25,64,7,57,50,50,29$, \\ $71,71,71,71,71,71,71,71,71,71,71,25,64,77,57,50,50,50,50$, \\ $71,71,71,71,71,71,71,71,71,71,71,25,64,7,5770,29,50,50,50$, \\ $71,71,71,71,71,71,71,71,71,71,71,25,64,77,57,50,50,50,50,50,50$, \\ $71,71,71,71,71,71,71,71,71,71,71,25,64,77,57,50,50,50,50,29,50,50$, \\ $26,25,25,25,25,25,25,25,25,25,25,26,64,64,7,57,50,29,50,50,50,50,27$, \\ 25 - side water cell \\ 26 - corner water cell \\ 27 - central tube cell \\ 29 - guide tube cell \\ 50 - high plutonium-content fuel rods \\ - intermediate plutonium-content fuel rods \\ 64 - low plutonium-content fuel rods \\ 71 - uranium $3.7 \% \mathrm{U}-235$ fuel rods
}


RUSSIAN RESEARCH CENTER KURCHATOV INSTITUTE

Design Studies of "100\%Pu" MOX Lead Test Assembly (Report for FY99)

\title{
Figure 2.7. Pins Numeration in CS Model
}

\author{
1 \\ 2,3 \\ 4, 5, 6 , \\ $7,8,9,10$ \\ $11,12,13,14,15$, \\ $16,17,18,19,20,21$, \\ $22,23,24,25,26,27,28$, \\ $29,30,31,32,33,34,35,36$, \\ $37,38,39,40,41,42,43,44,45$, \\ $46,47,48,49,50,51,52,53,54,55$, \\ $56,57,58,59,60,61,62,63,64,65,66$, \\ $67,68,69,70,71,72,73,74,75,76,77,78$, \\ $79,80,81,82,83,84,85,86,87,88,89,90,91$, \\ $92,93,94,95,96,97,98,99,100,101,102,103,104,105$, \\ $106,107,108,109,110,111,112,113,114,115,116,117,118,119,120$, \\ $121,122,123,124,125,126,127,128,129,130,131,132,133,134,135,136$, \\ $137,138,139,140,141,142,143,144,145,146,147,148,149,150,151,152,153$, \\ $154,155,156,157,158,159,160,161,162,163,164,165,166,167,168,169,170,171$, \\ $172,173,174,175,176,177,178,179,180,181,182,183,184,185,186,187,188,189,190$, \\ $191,192,193,194,195,196,197,198,199,200,201,202,203,204,205,206,207,208,209,210$, \\ $211,212,213,214,215,216,217,218,219,220,221,222,223,224,225,226,227,228,229,230,231$, \\ $232,233,234,235,236,237,238,239,240,241,242,243,244,245,246,247,248,249,250,251,252,253$, \\ $\mathbf{2 5 4}, 255,256,257,258,259,260,261,262,263,264,265,266,267,268,269,270,271,272,273,274,275,276$, \\ 257 - side water cell \\ 254 - corner water cell \\ 276 - central tube cell \\ 137 - guide tube cell / burnable absorber \\ 223 -plutonium fuel rods \\ 71 - uranium $3.7 \% \mathrm{U}-235$ fuel rods
}


Figure 2.8. Evolution of Ko in Plutonium-Uranium Super-Cells

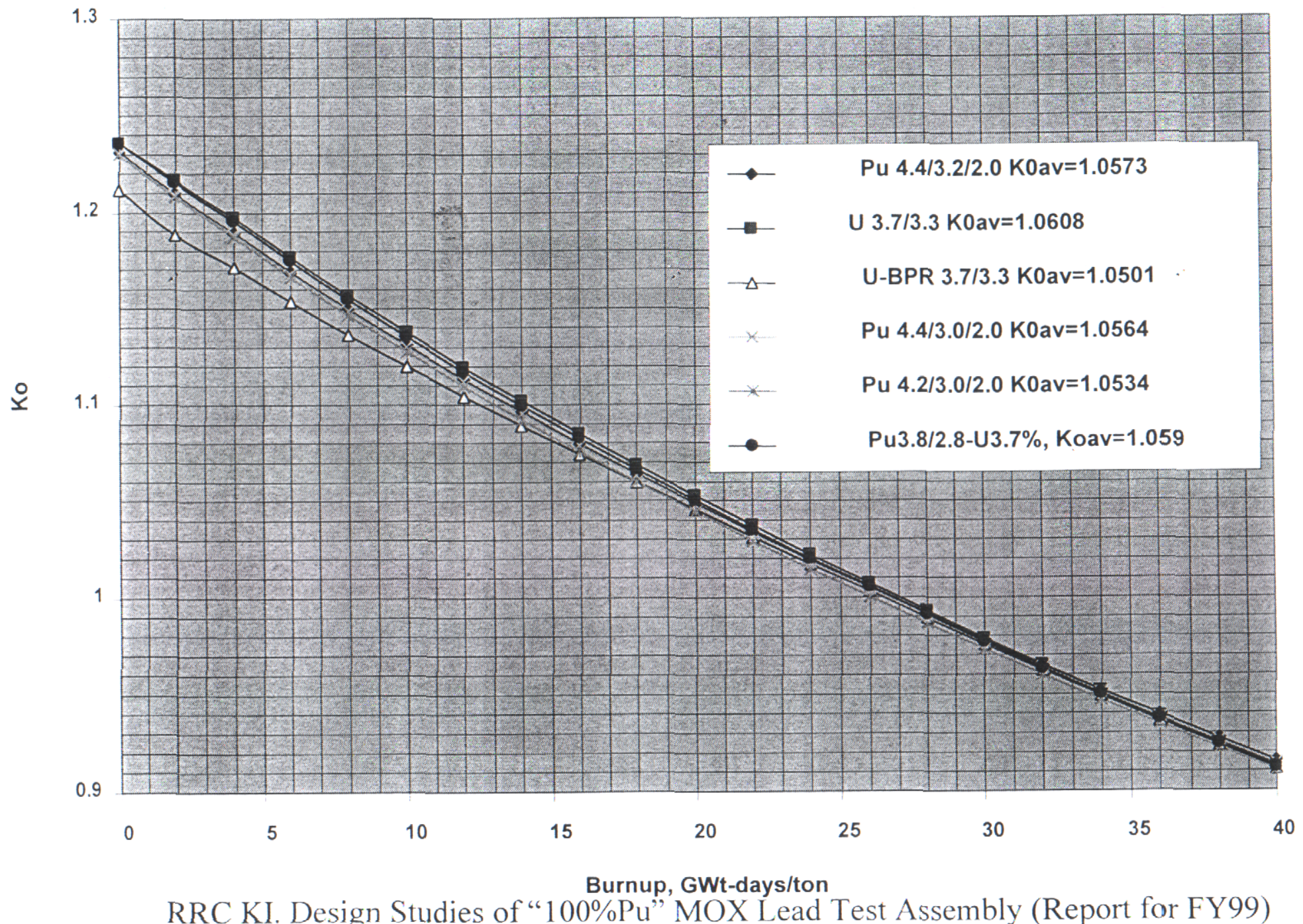


Figure 2.9. Evolution of Kk in Plutonium-Uranium Super-Cells

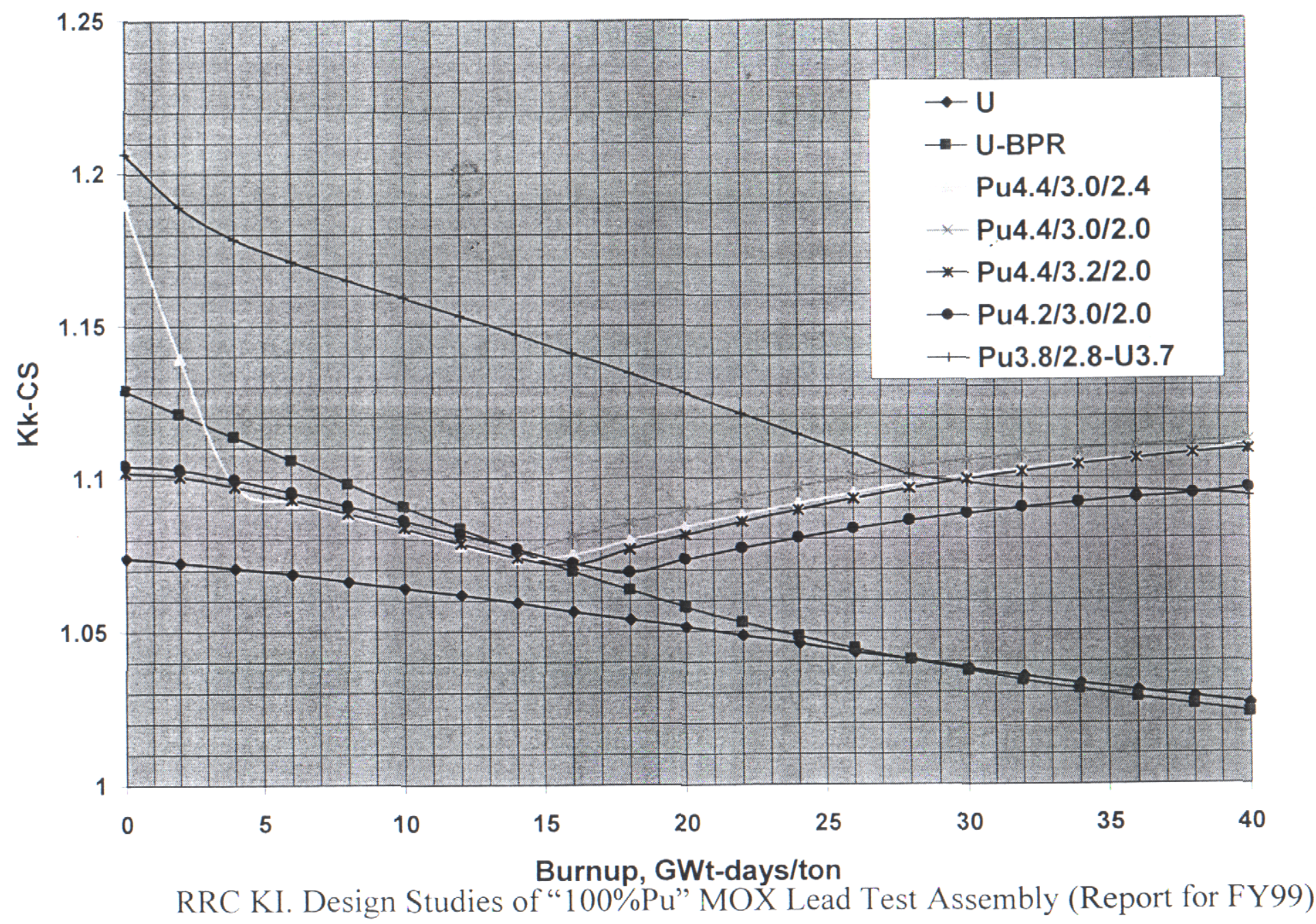


RUSSIAN RESEARCH CENTER KURCHATOV INSTITUTE

Design Studies of "100\%Pu" MOX Lead Test Assembly (Report for FY99)

Figure 3.1. Symmetric element of the core

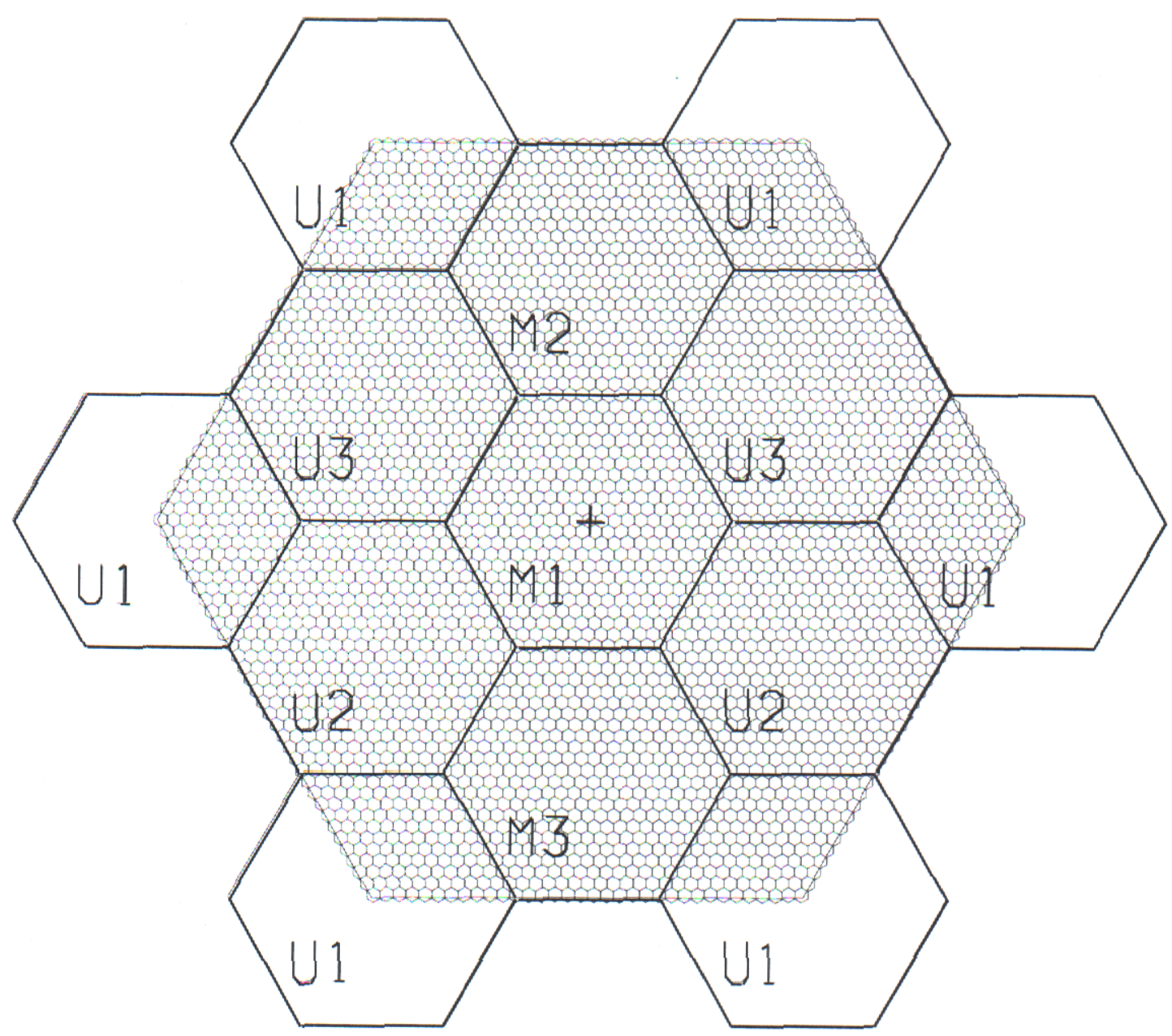


RUSSIAN RESEARCH CENTER KURCHATOV INSTITUTE

Design Studies of " $100 \%$ Pu" MOX Lead Test Assembly (Report for FY99)

Figure 3.2. FA arrangements in symmetric element

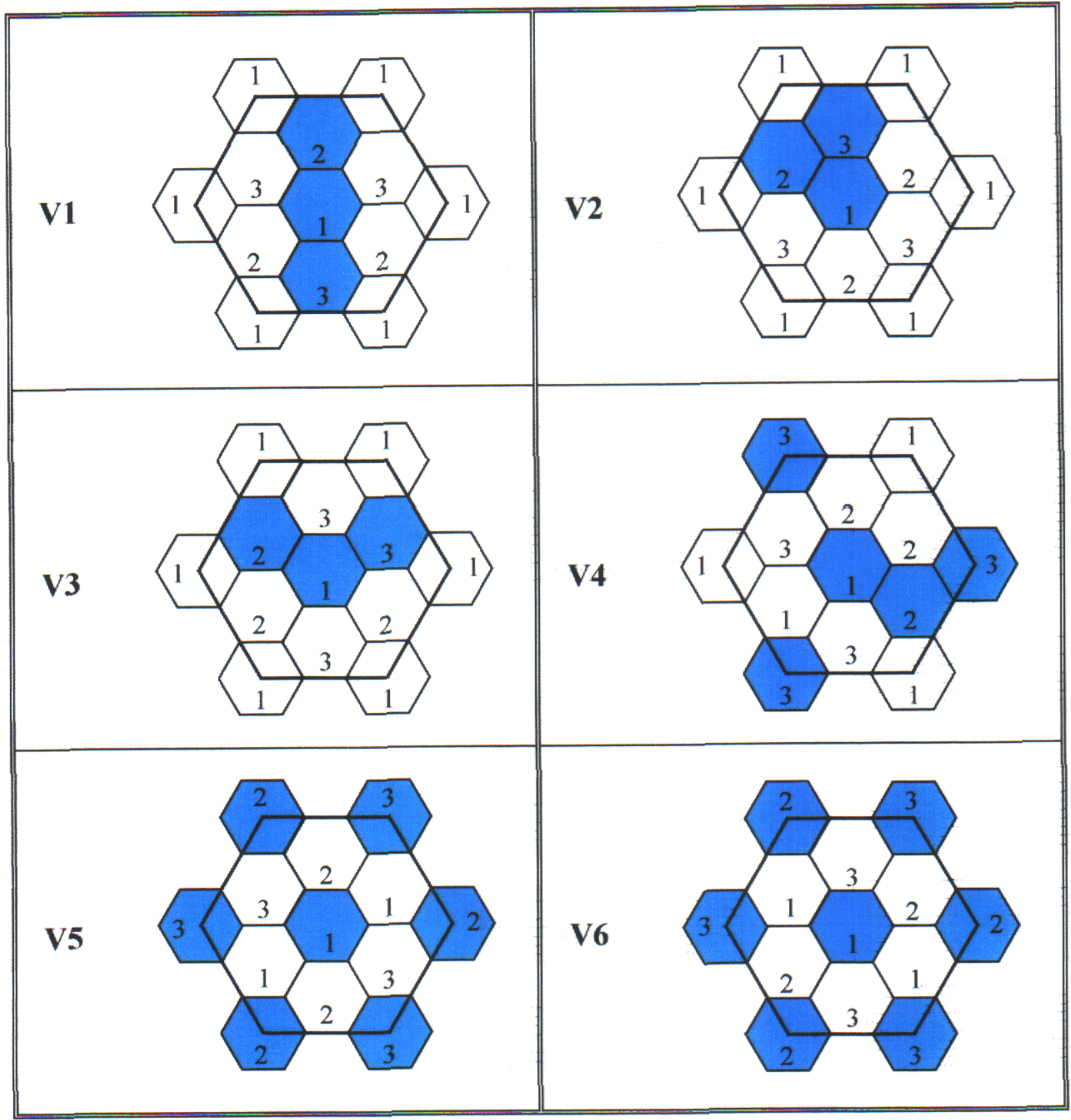


RUSSIAN RESEARCH CENTER KURCHATOV INSTITUTE

Design Studies of "100\%Pu" MOX Lead Test Assembly (Report for FY99)

Figure 3.3. Power peaking factors $K_{K \max }-C S(K k-C S)$ and $K_{K \max }-C A\left(K_{K}-\right.$ CA) versus $P u$ content in a central FA
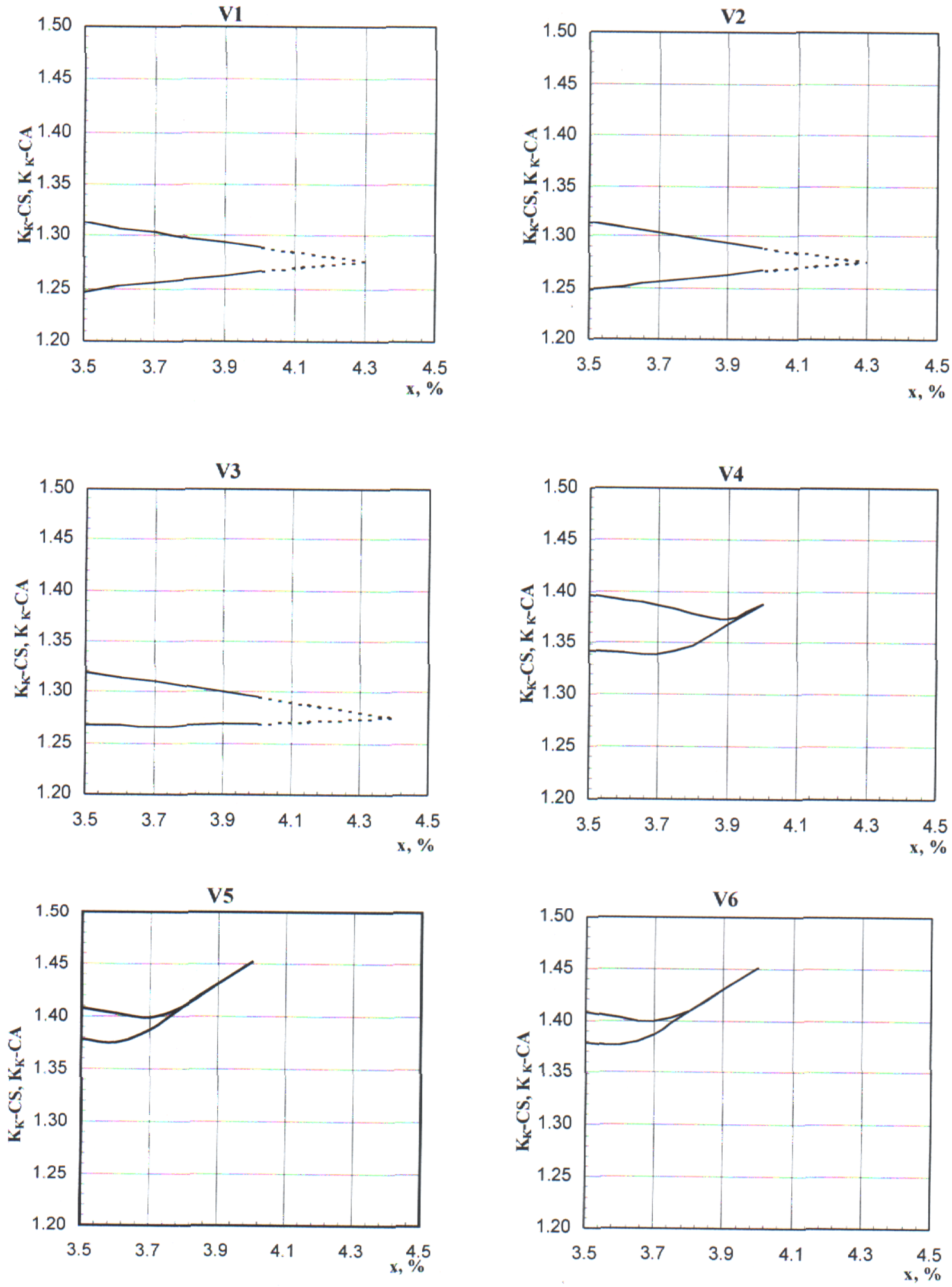
RUSSIAN RESEARCH CENTER KURCHATOV INSTITUTE

Design Studies of " $100 \%$ Pu" MOX Lead Test Assembly (Report for FY99)

Fig. 3.4. FA arrangements in symmetric element

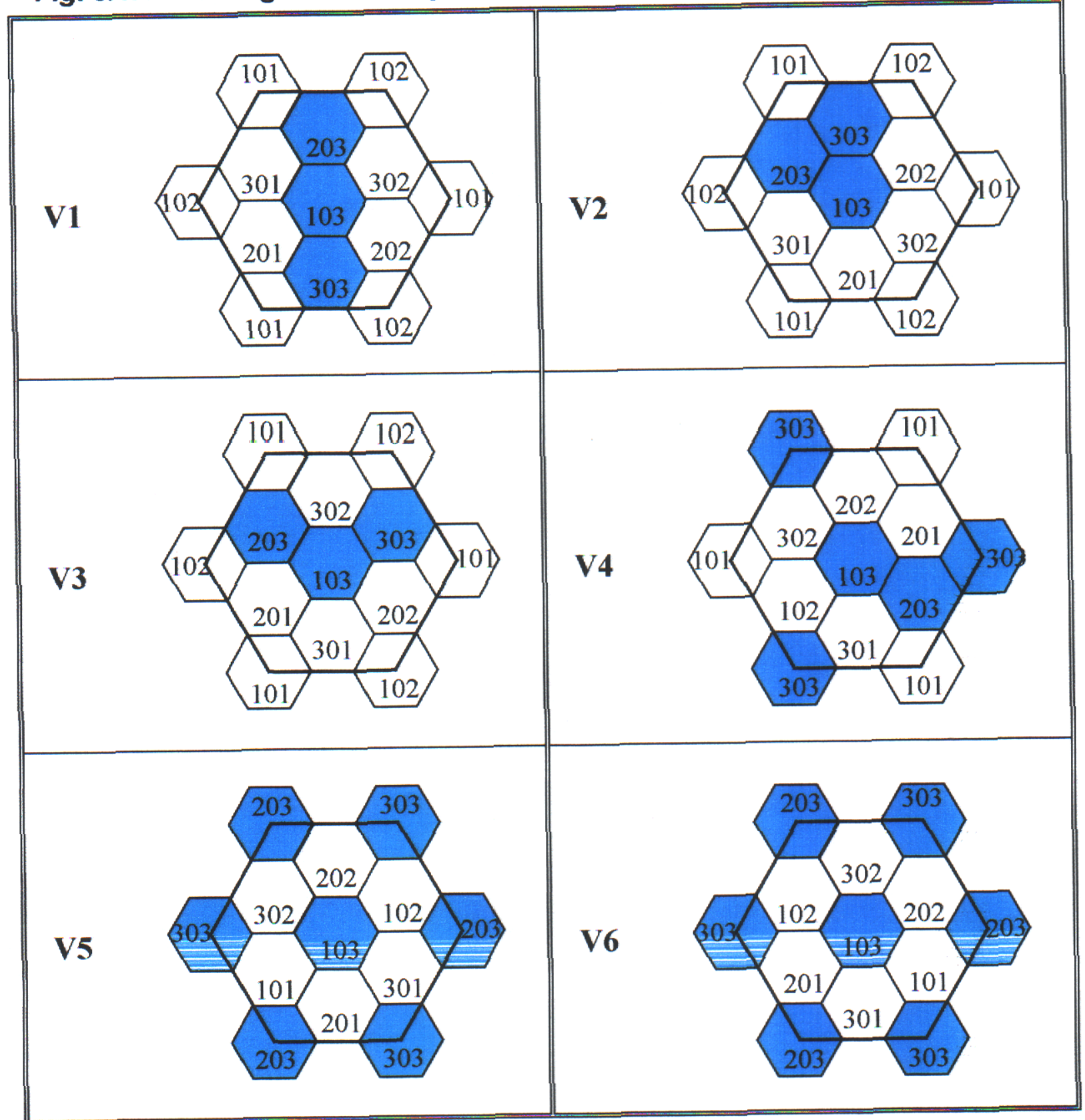


RUSSIAN RESEARCH CENTER KURCHATOV INSTITUTE

Design Studies of “100\%Pu” MOX Lead Test Assembly (Report for FY99)

Fig. 3.5. Effect of fuel reloadings and burnups on $K_{K \max }-C S$ and $K_{K \max }-C A$ . $C B=1200, \ldots, 0 \mathrm{ppm}$

Cycle 0
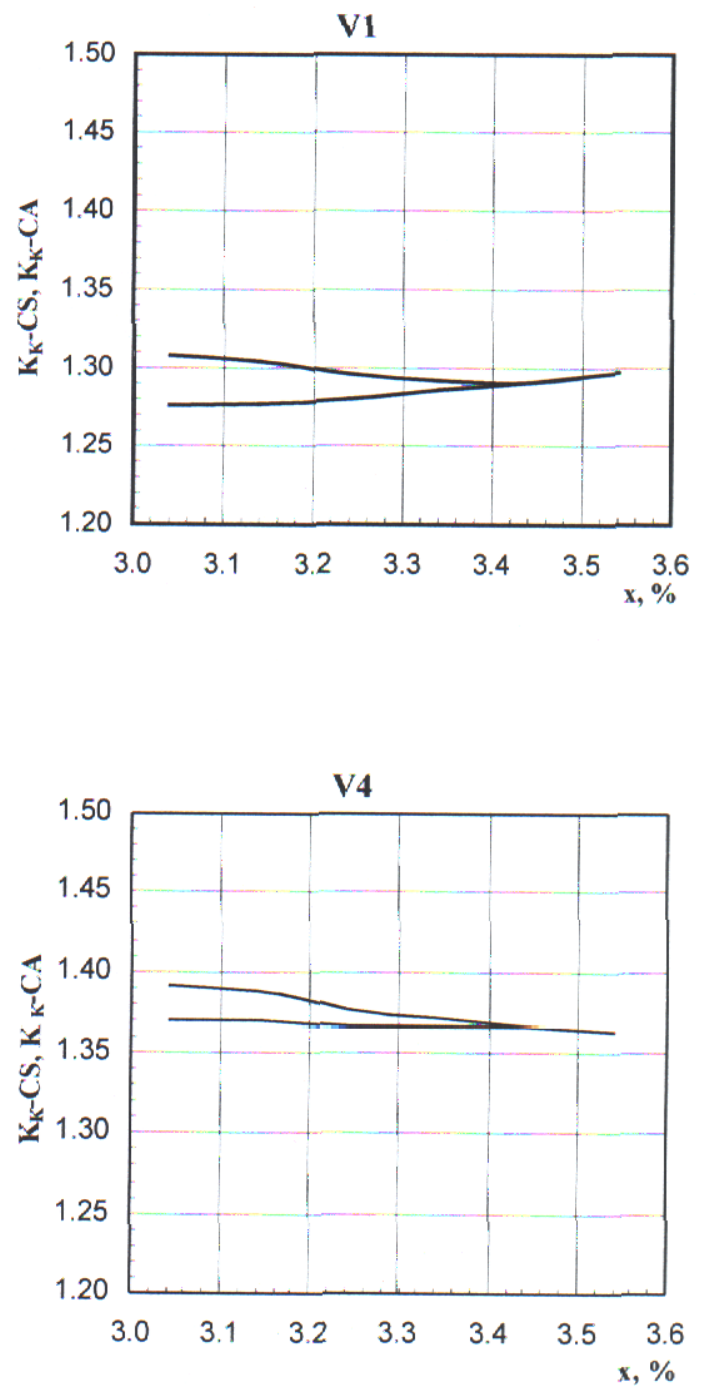

Cycle 5
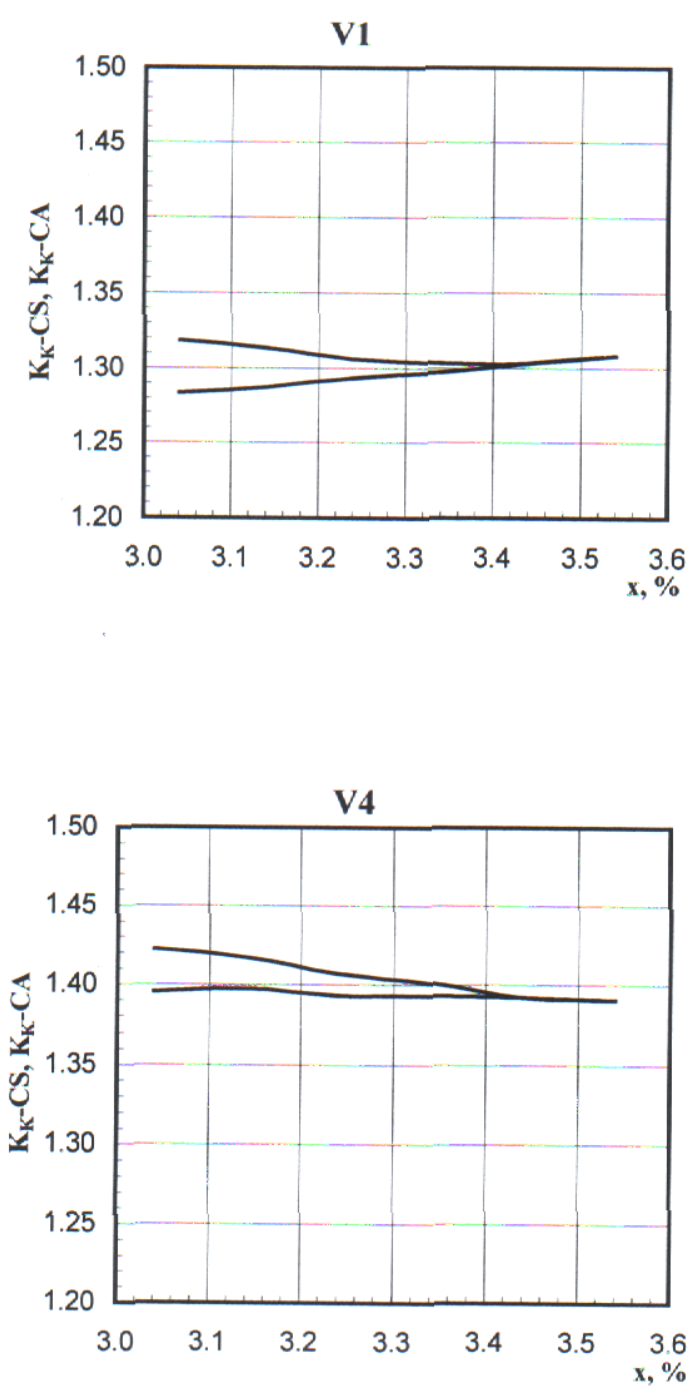
RUSSIAN RESEARCH CENTER KURCHATOV INSTITUTE

Design Studies of "100\%Pu” MOX Lead Test Assembly (Report for FY99)
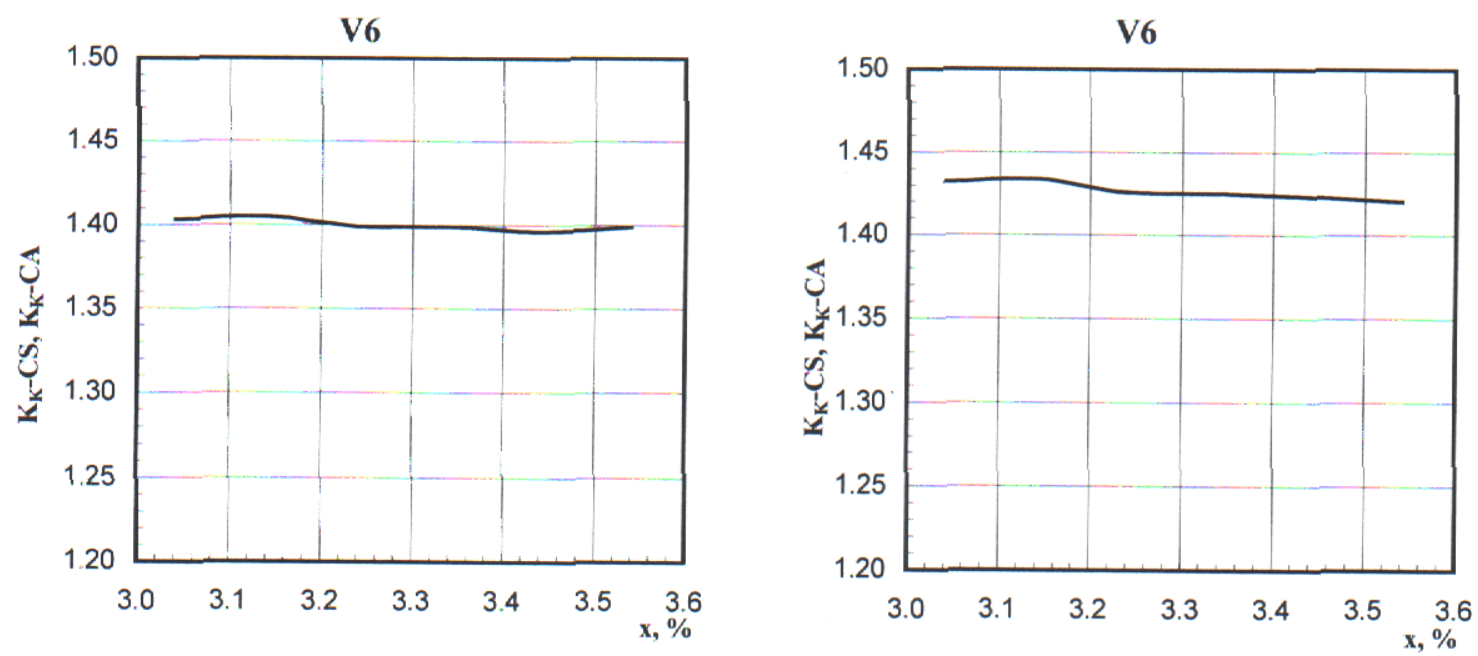
Fig. 3.6. $K_{K \max }-C S$ and $K_{K \max }-C A$ versus from Pu content in a central FA
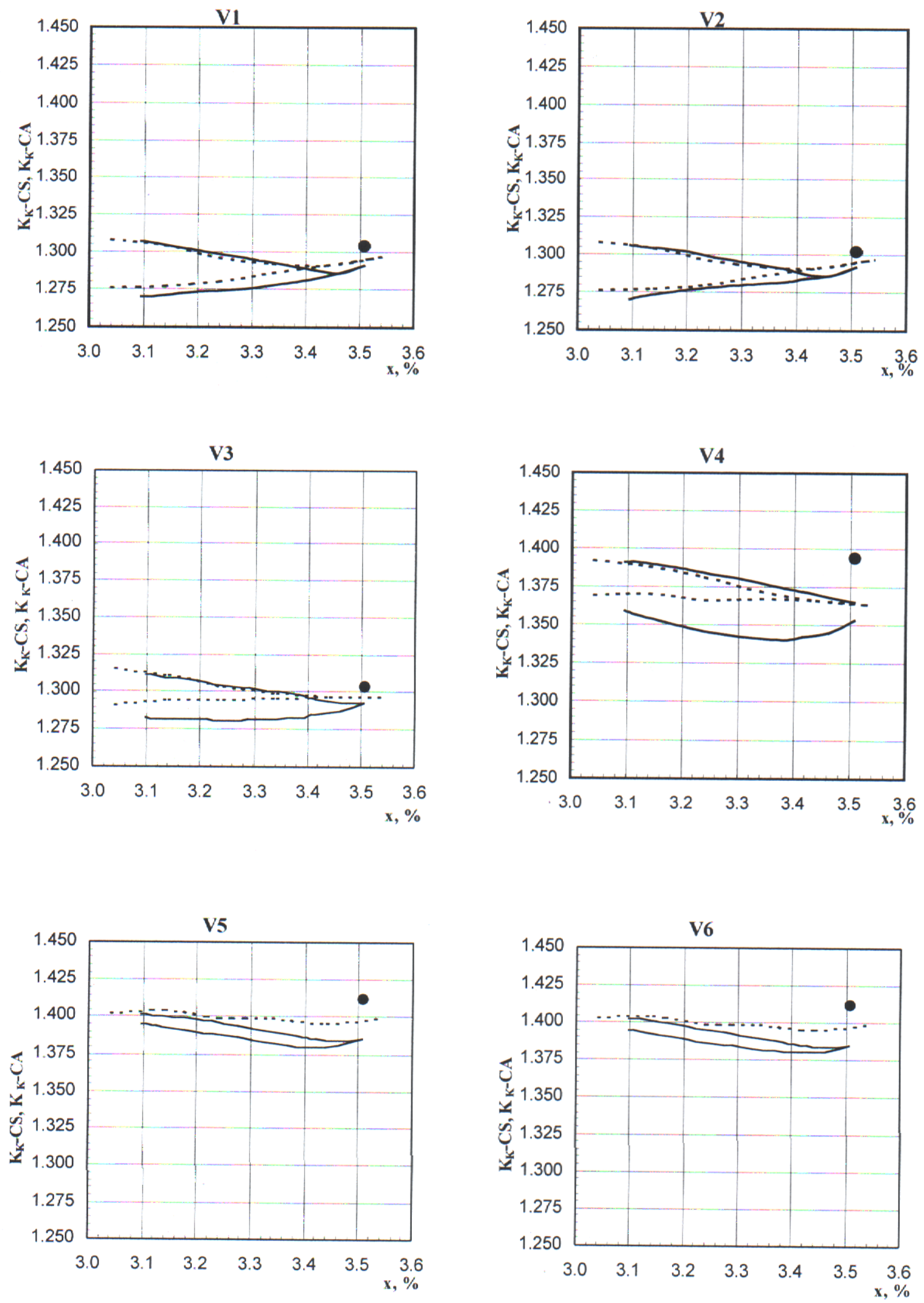
Fig.4.1. Assembly-by-Assembly Burnup, Power and Temperature Drops Distributions. Equilibrium Cycle for Uranium Reference Core with Boron BPRs. Core $60^{\circ}$ Sector
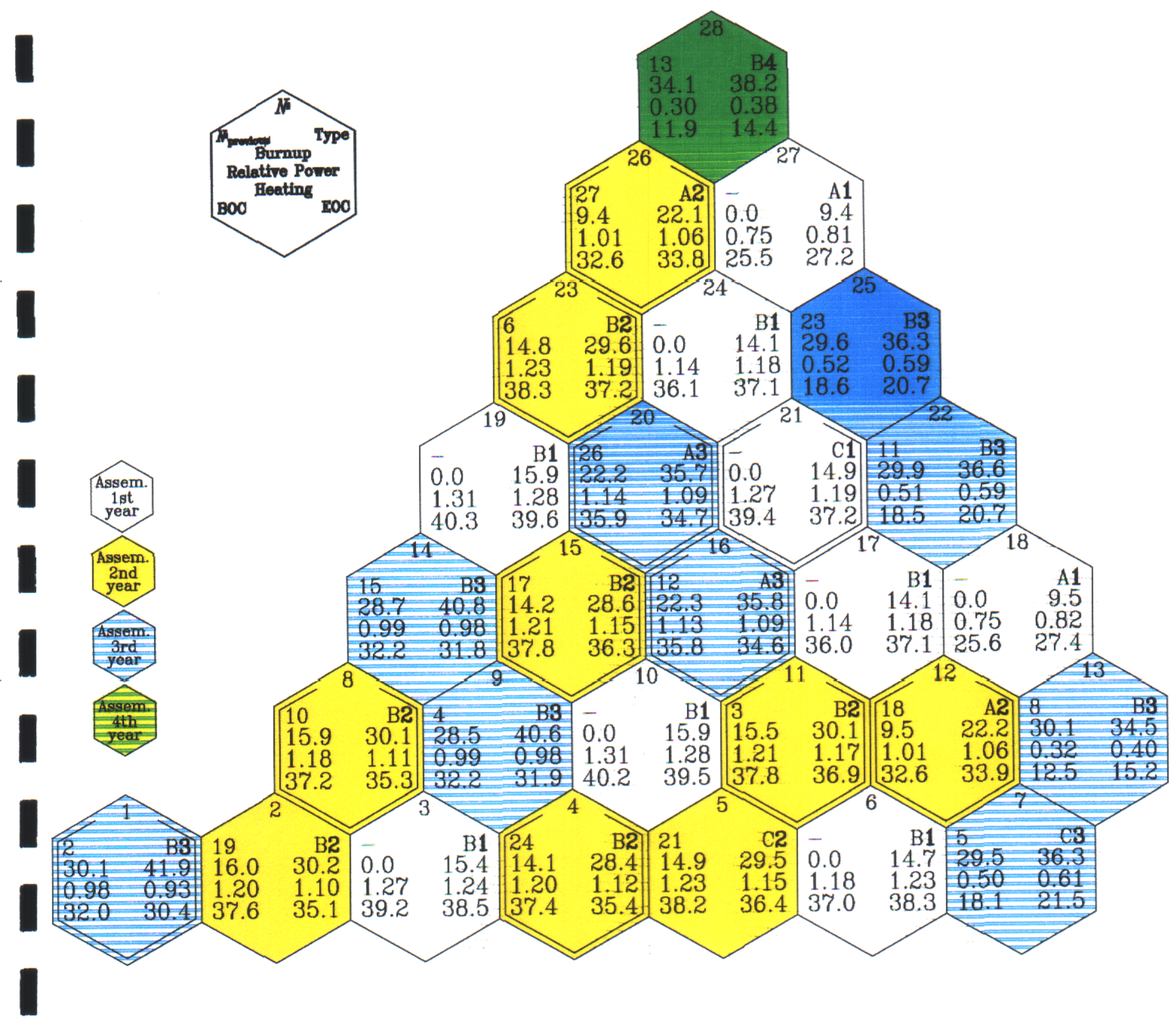
$\begin{array}{llll}30.1 & 41.9 & 16.0\end{array}$ $0.98 \quad 0.93 \quad 1.20$ $\begin{array}{lll}0.90 & 0.93 & 30.4 \\ 37.6 & 35.1\end{array}$ 
Fig.4.2. Assembly-by-Assembly Maximum Linear Pin Power Distribution in BOC. Equilibrium Cycle for Uranium Reference Core with Boron BPRs. Core $60^{\circ}$ Sector

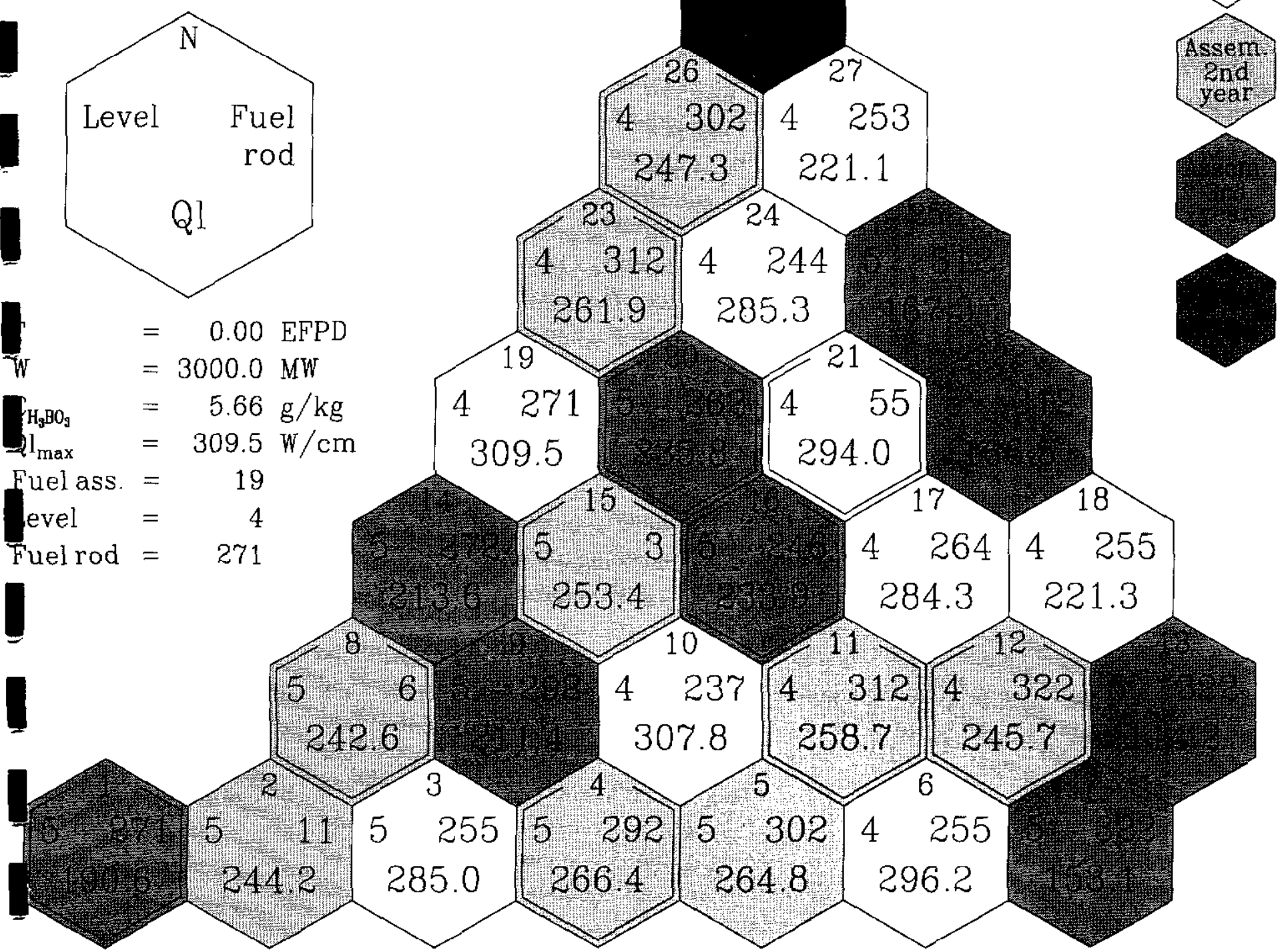


Fig.4.3. Assembly-by-Assembly Maximum Linear Pin Power Distribution in EOC.

Equilibrium Cycle for Uranium Reference Core with Boron BPRs.Core $60^{\circ}$ Sector

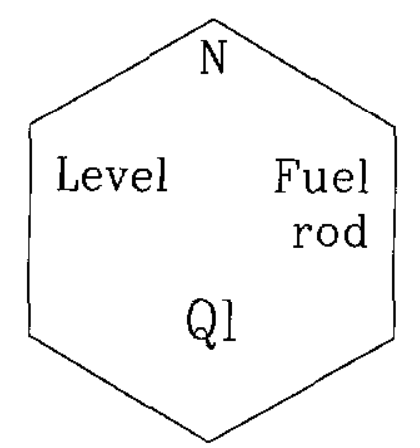

I

$\mathrm{T} \quad=286.88 \mathrm{EFPD}$

$\mathrm{W} \quad=3000.0 \mathrm{MW}$

$\mathrm{C}_{\mathrm{H}_{\mathrm{g}} \mathrm{BO}_{3}}=0.00 \mathrm{~g} / \mathrm{kg}$

$\mathrm{Ql}_{\max }=253.5 \mathrm{~W} / \mathrm{cm}$

Fuel ass. $=19$

Level $=2$

Fuel rod $=272$

9

2

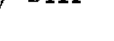

253.5

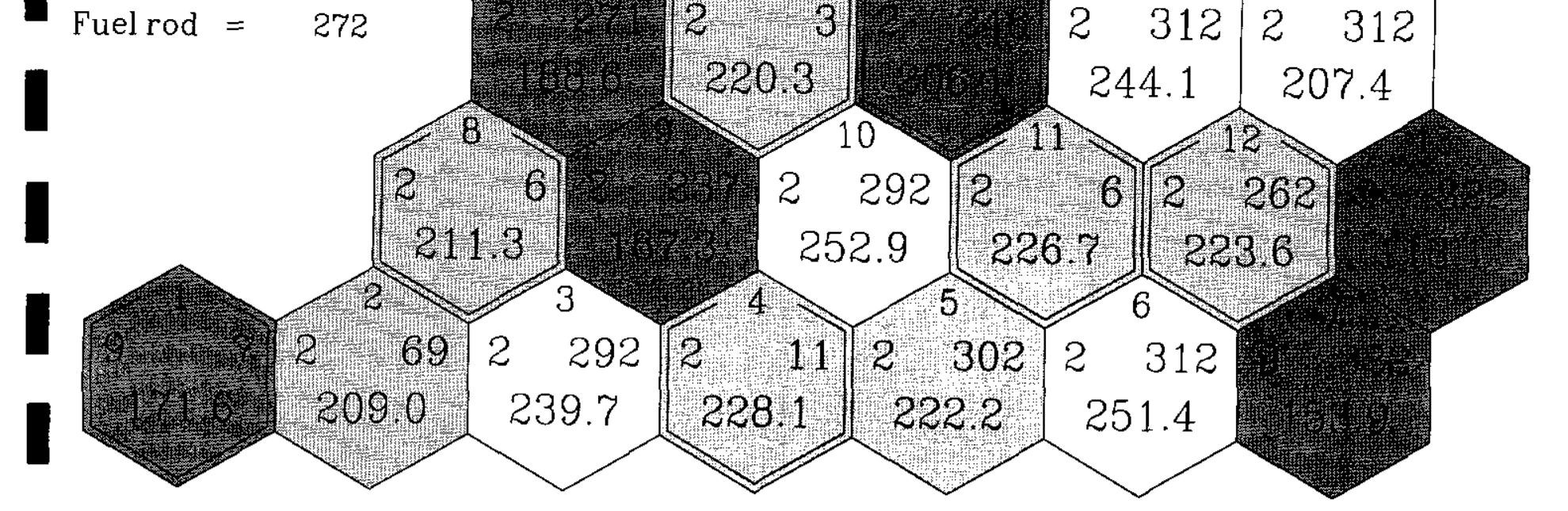


Fig.4.4. Pin-by-Pin Power Distribution in the Most Powered Assembly in BOC. Equilibrium Cycle for Uranium Reference Core with Boron BPRs

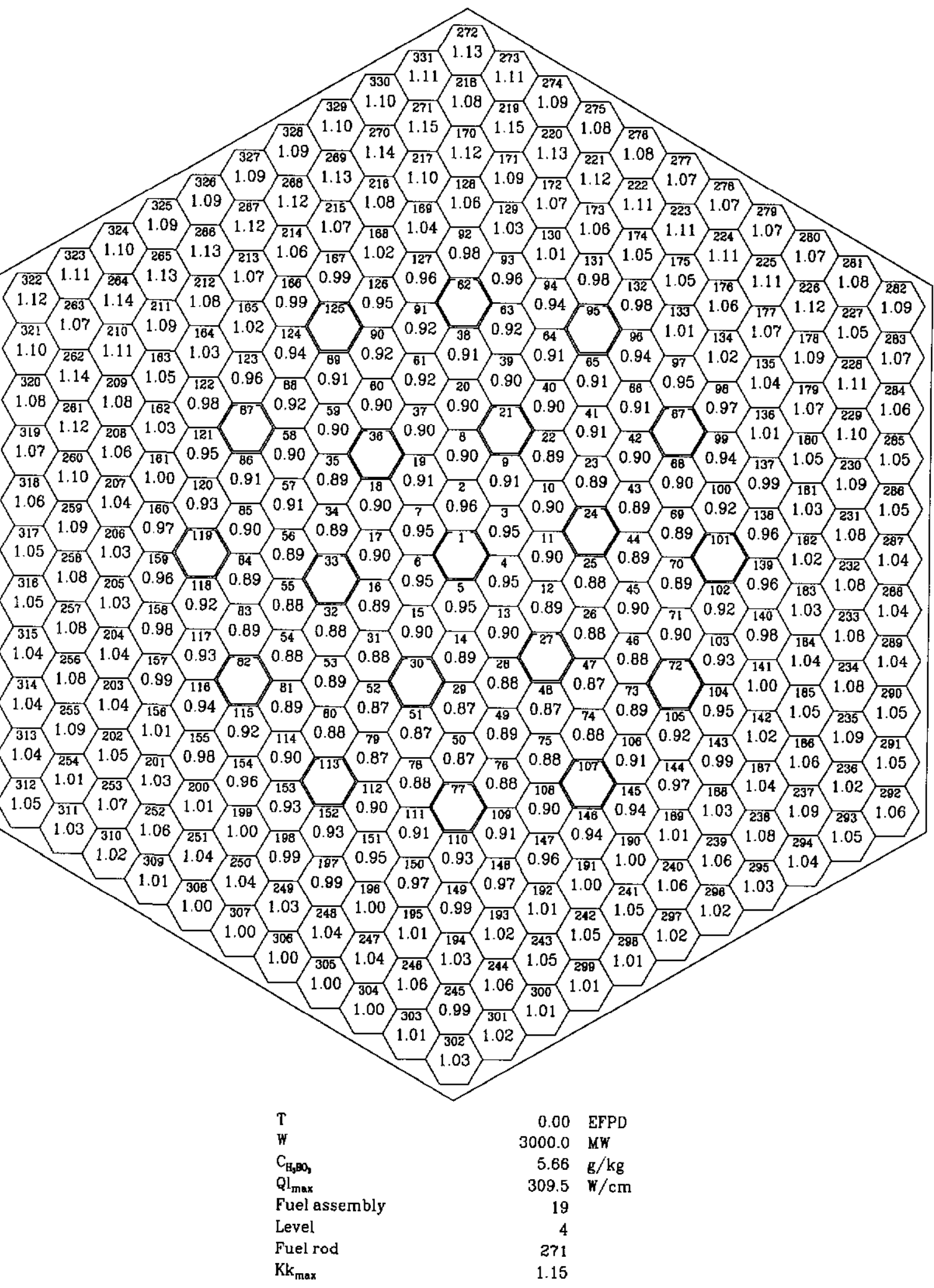


Fig.4.5. Pin-by-Pin Power Distribution in the Most Powered Assembly in EOC. Equilibrium Cycle for Uranium Reference Core with Boron BPRs

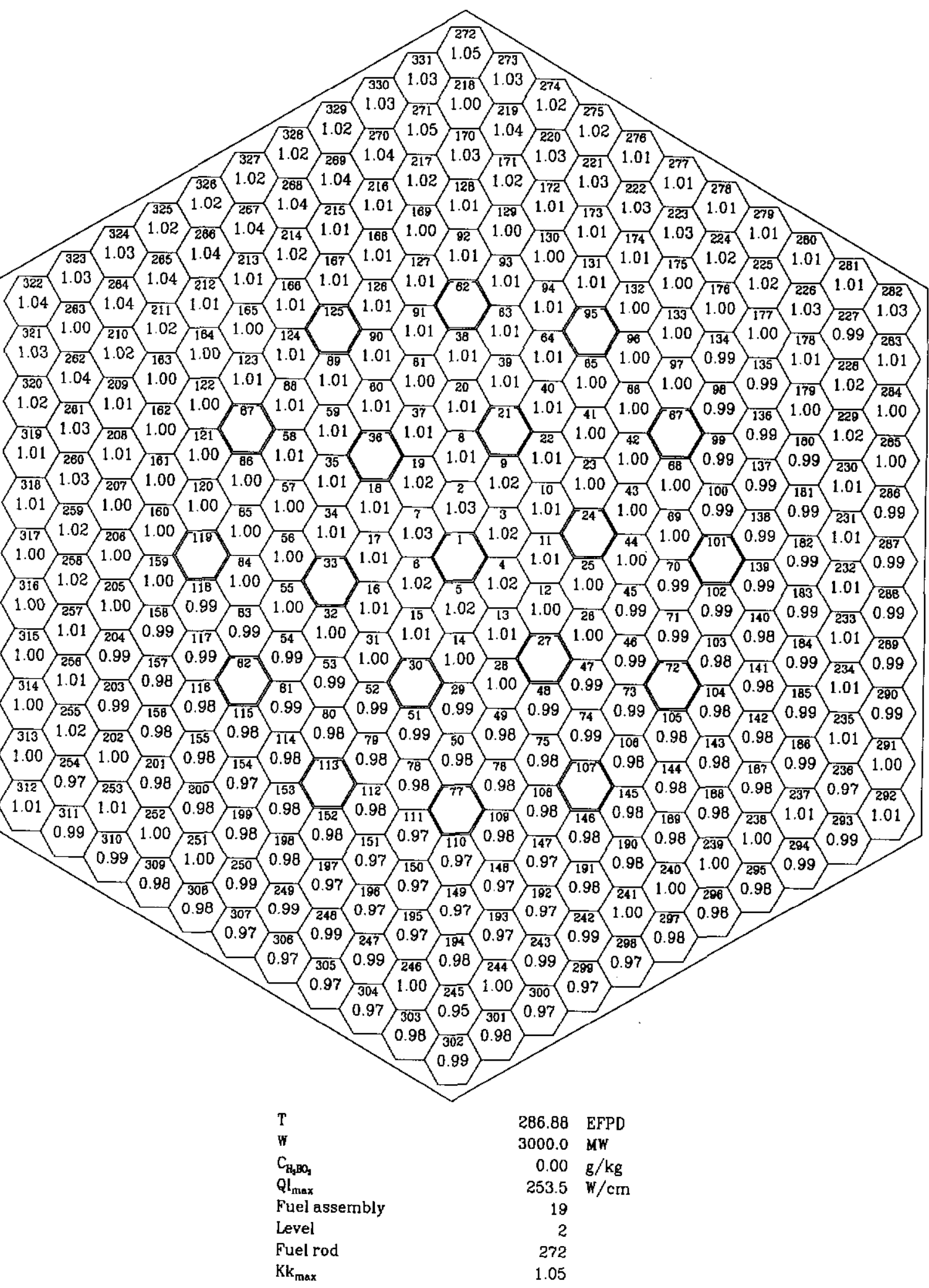


Figure 4.6. Control Rods Grouping and Positions of In-core Self-Powered Detectors

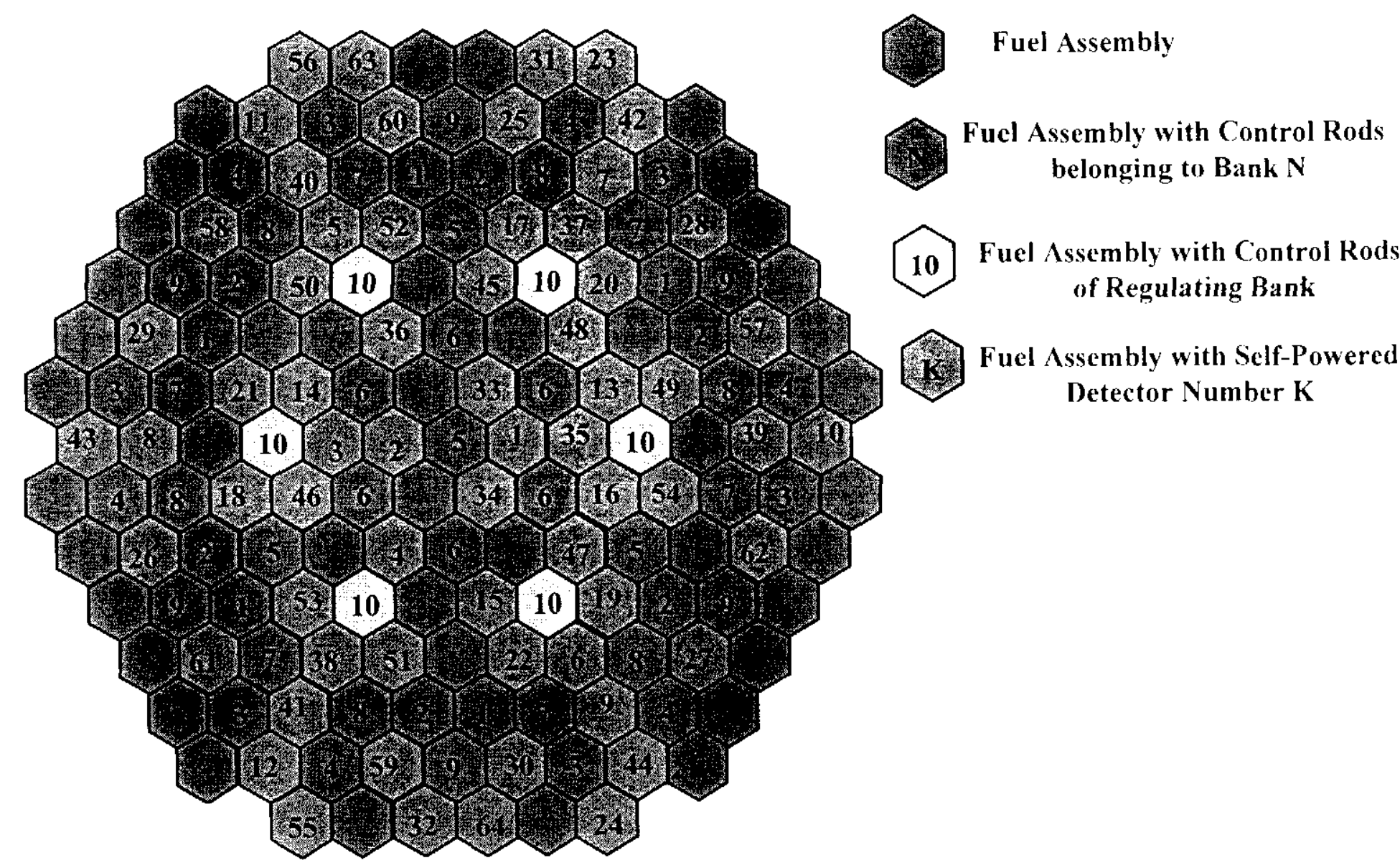

RRC KI. Design Studies of "100\%Pu" MOX Lead Test Assembly (Report for FY99) 
Fig.4.8. Assembly-by-Assembly Power Distribution.

First Cycle with 3 "100\%Pu" MOX LTAs

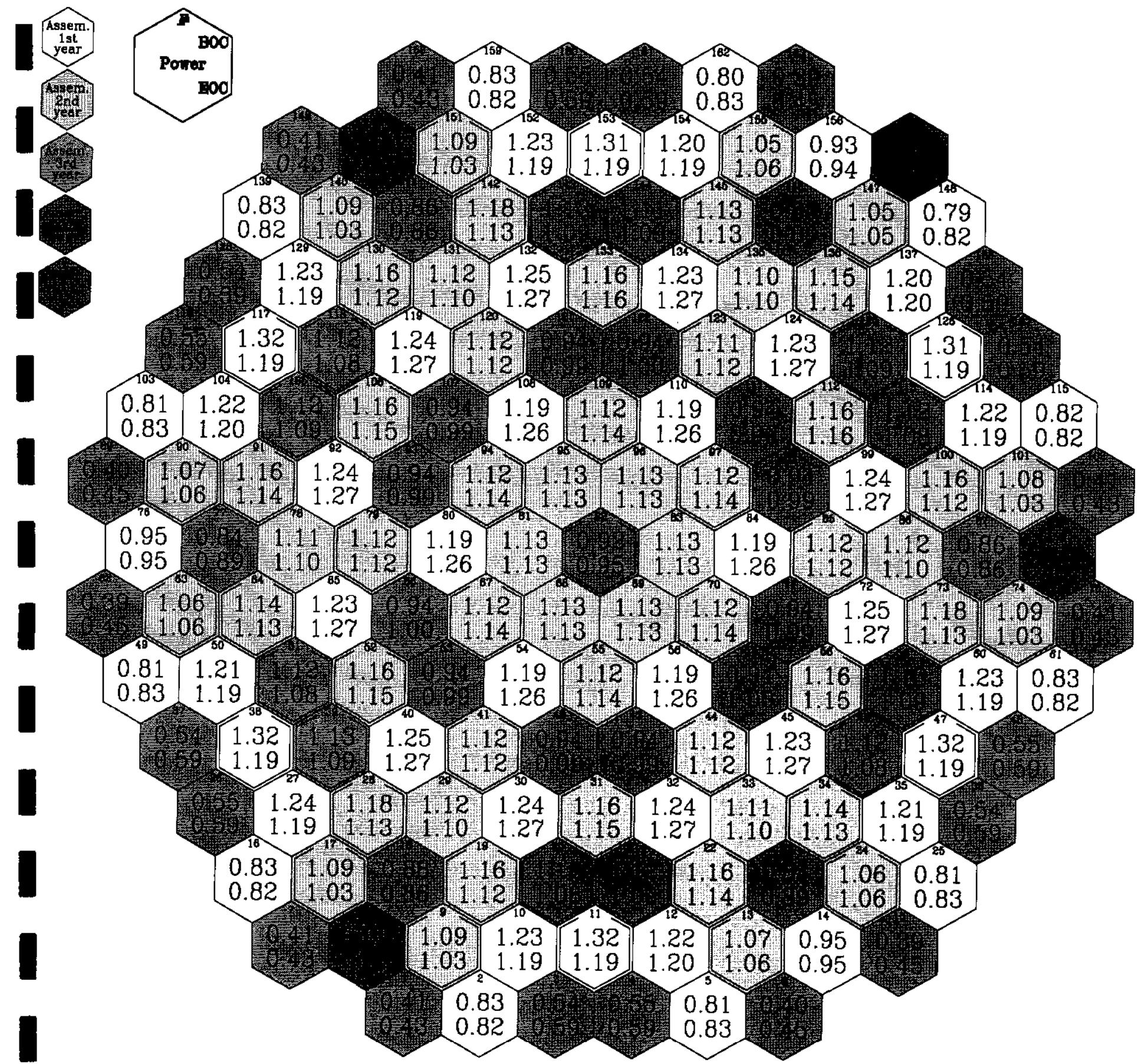


Fig.4.9. Assembly-by-Assembly Burnup Distribution.

First Cycle with 3 "100\%Pu" MOX LTAs

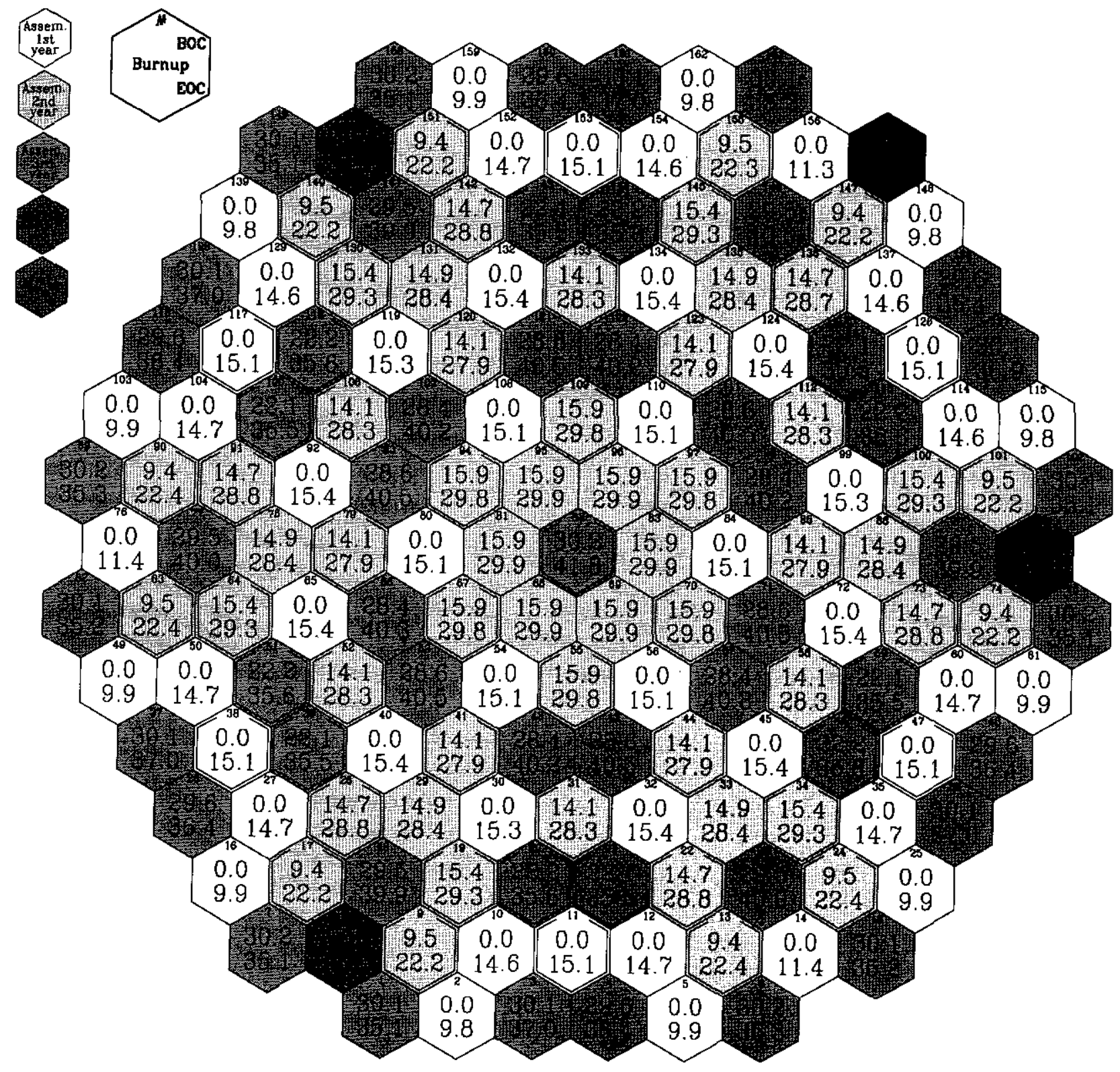


Fig.4.10. Assembly-by-Assembly Temperature Drop Distribution.

First Cycle with 3 "100\%Pu" MOX LTAs

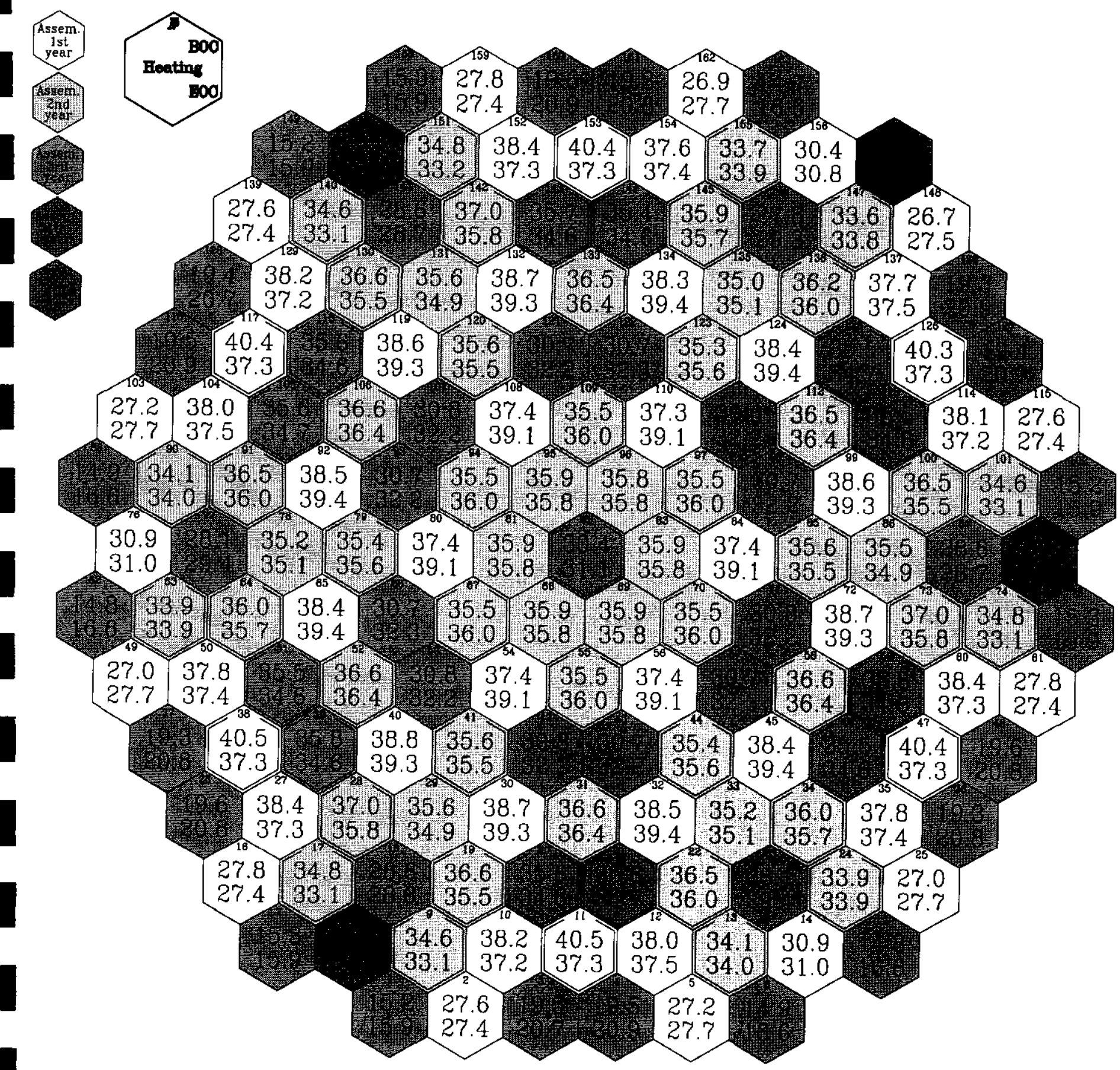


Fig.4.11. Assembly-by-Assembly Maximum Linear Power Distribution in BOC. First Cycle with 3 "100\%Pu" MOX LTAs

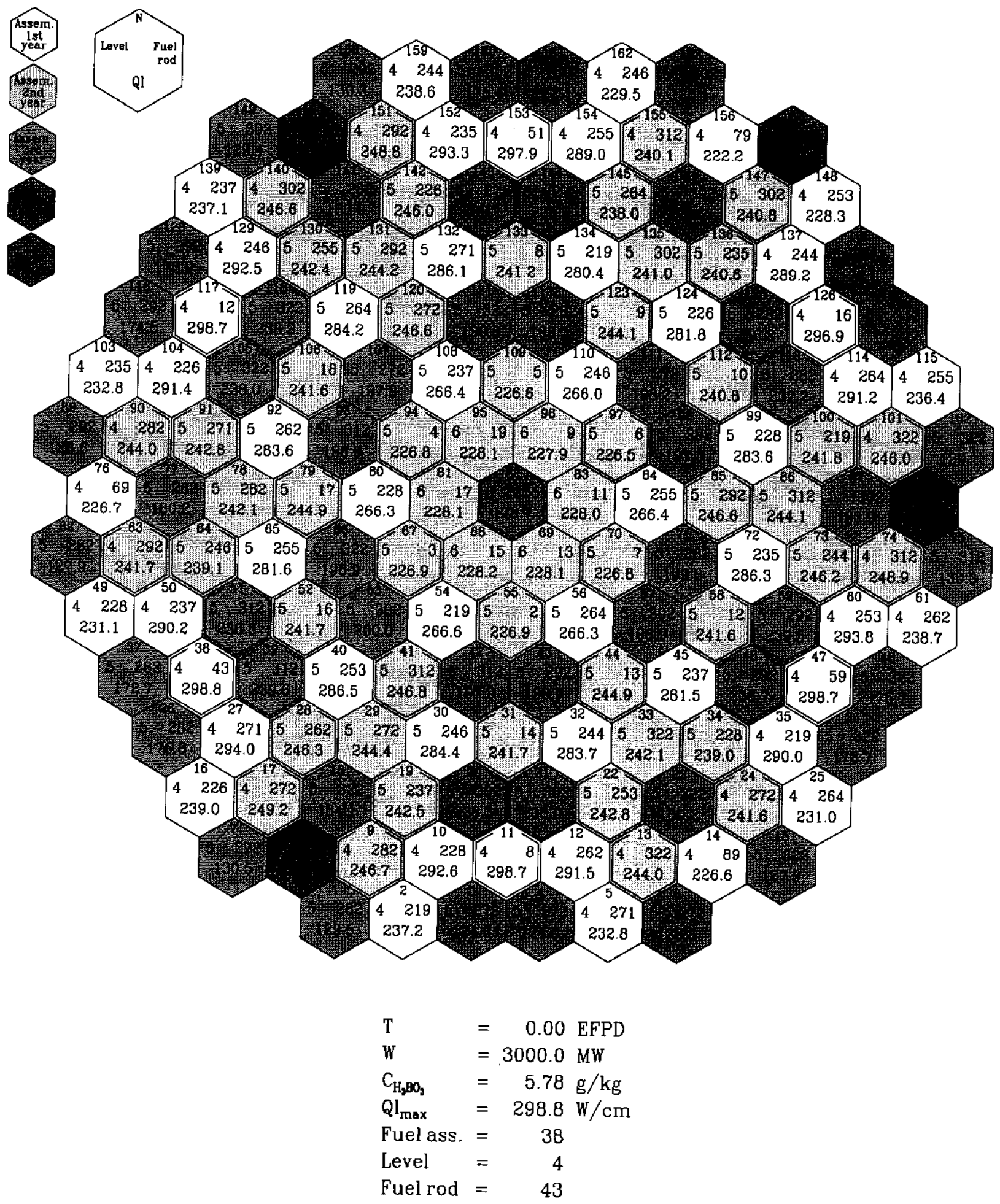


Fig.4.12. Assembly-by-Assembly Maximum Linear Power Distribution in EOC. First Cycle with 3 "100\%Pu" MOX LTAs

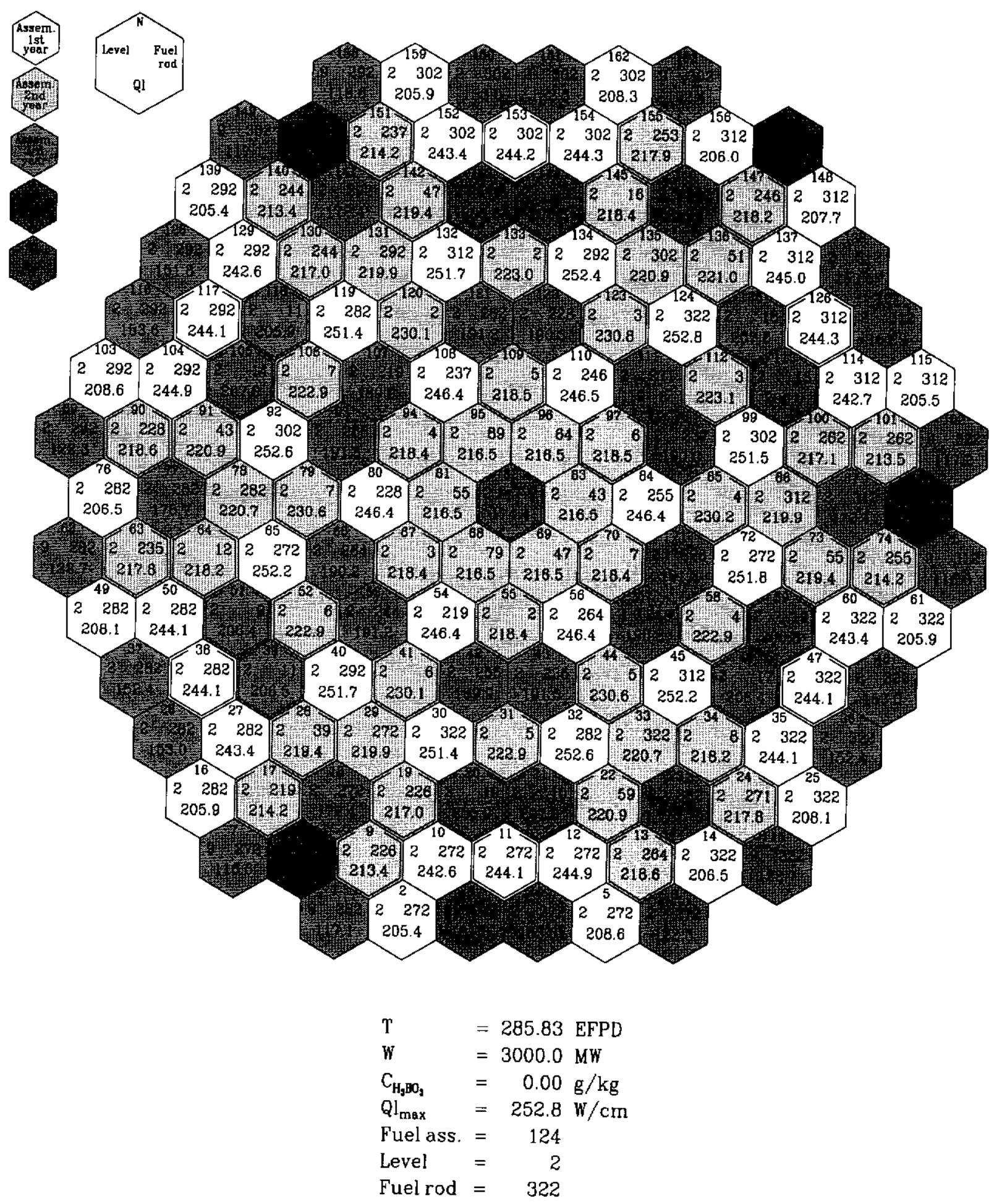


Fig.4.13. Pin-by-Pin Power Distribution in the Most Powered Assembly in BOC. First Cycle with 3 "100\%Pu" MOX LTAs

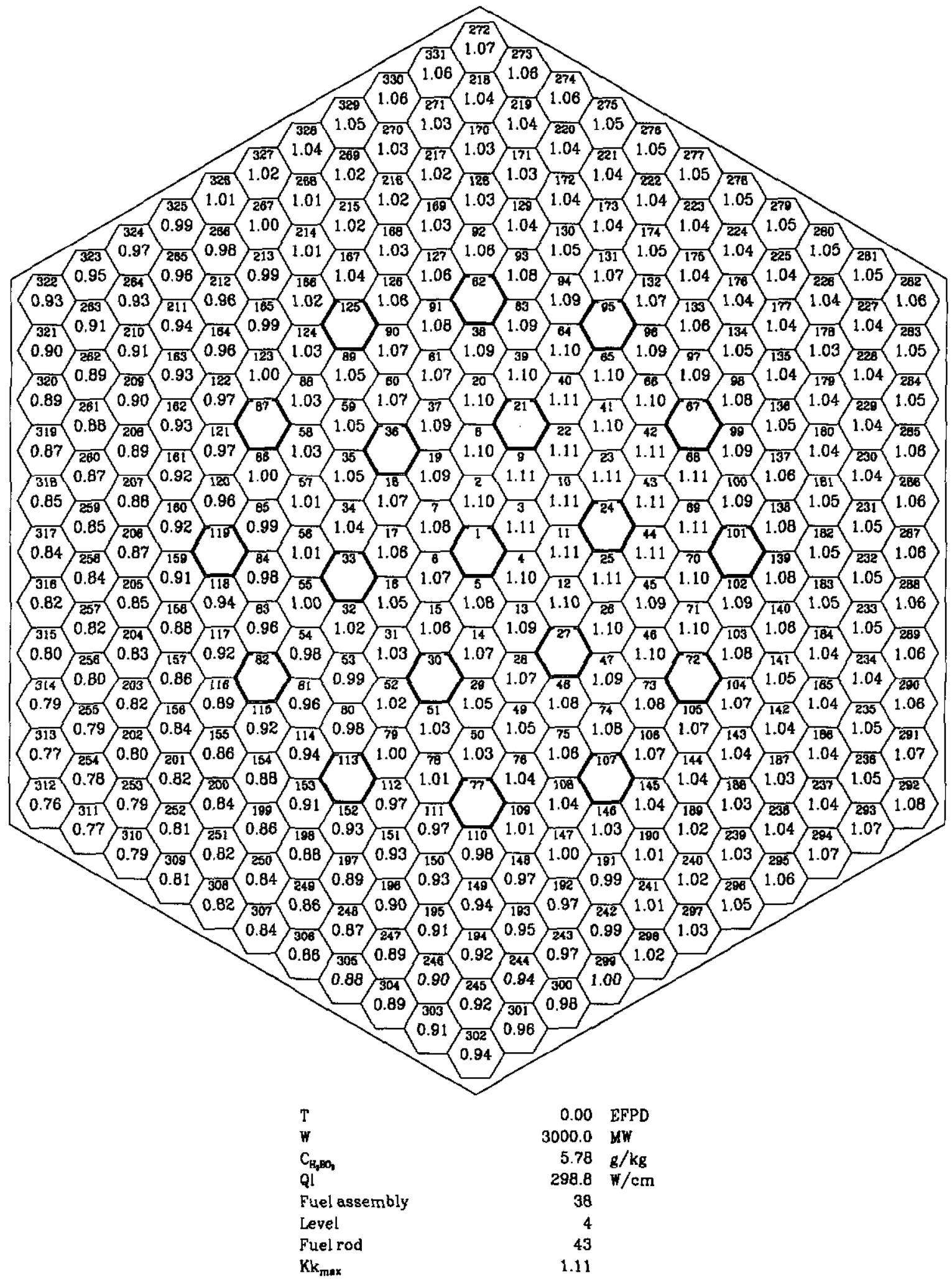


Fig.4.14. Pin-by-Pin Power Distribution in the Most Powered Assembly in EOC. First Cycle with 3 "100\%Pu" MOX LTAs

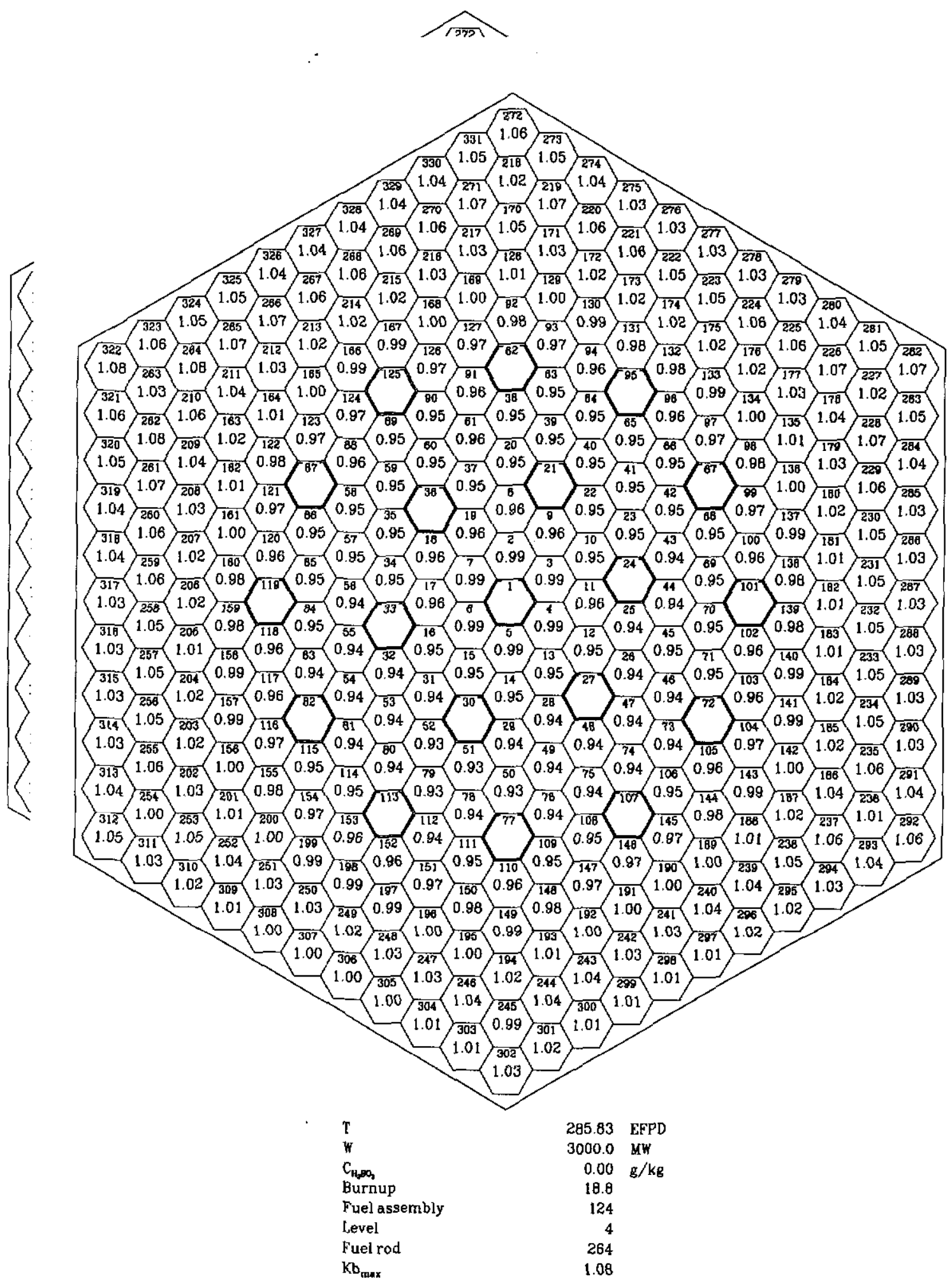


Fig.4.15. Pin-by-Pin Power Distribution in MOX LTA in BOC. First Cycle with 3 "100\%Pu" MOX LTAS

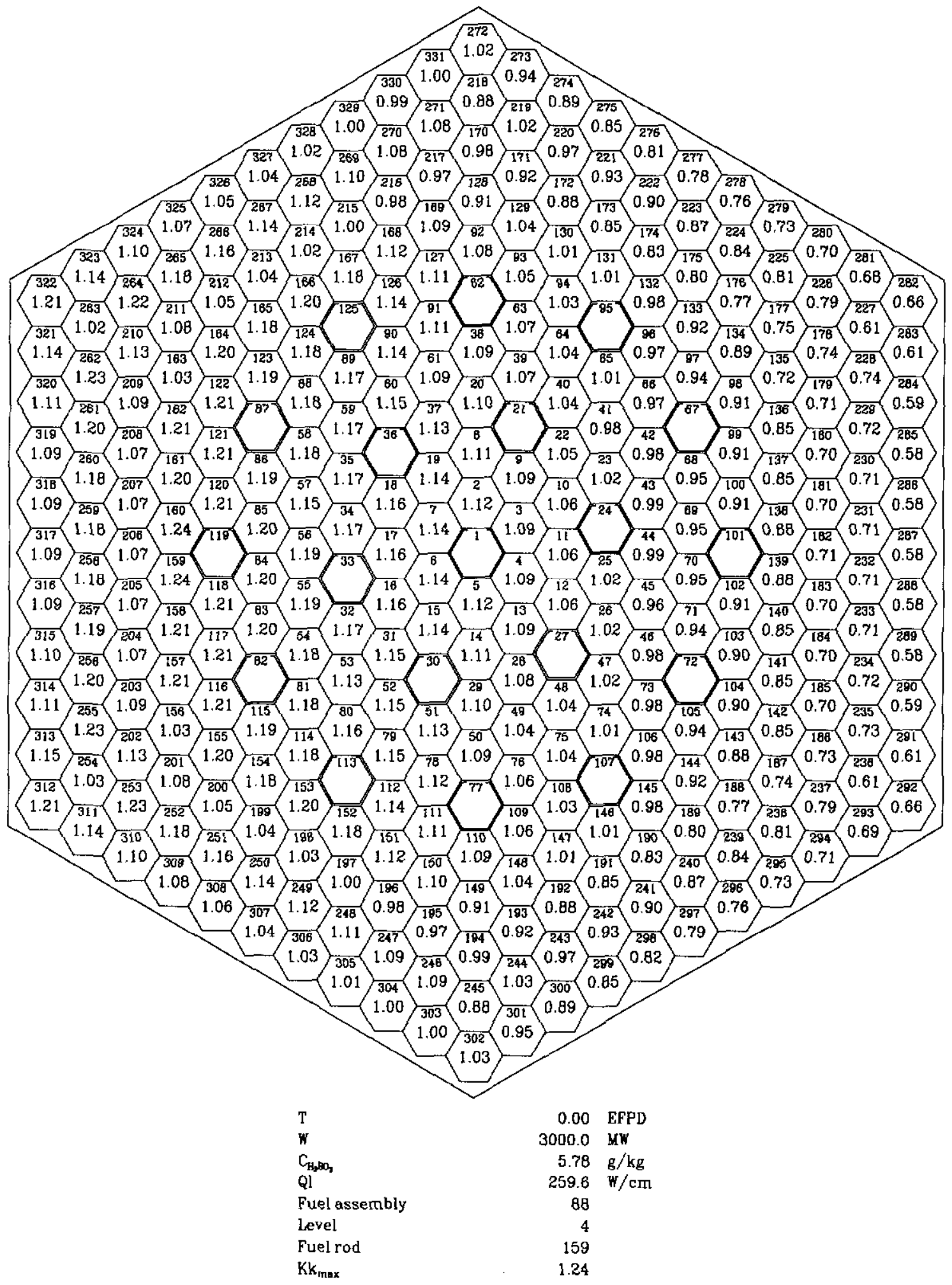



Fig.4.16. Pin-by-Pin Power Distribution in MOX LTA in EOC. First Cycle with 3 MOX
"100\%Pu" MOX LTAs

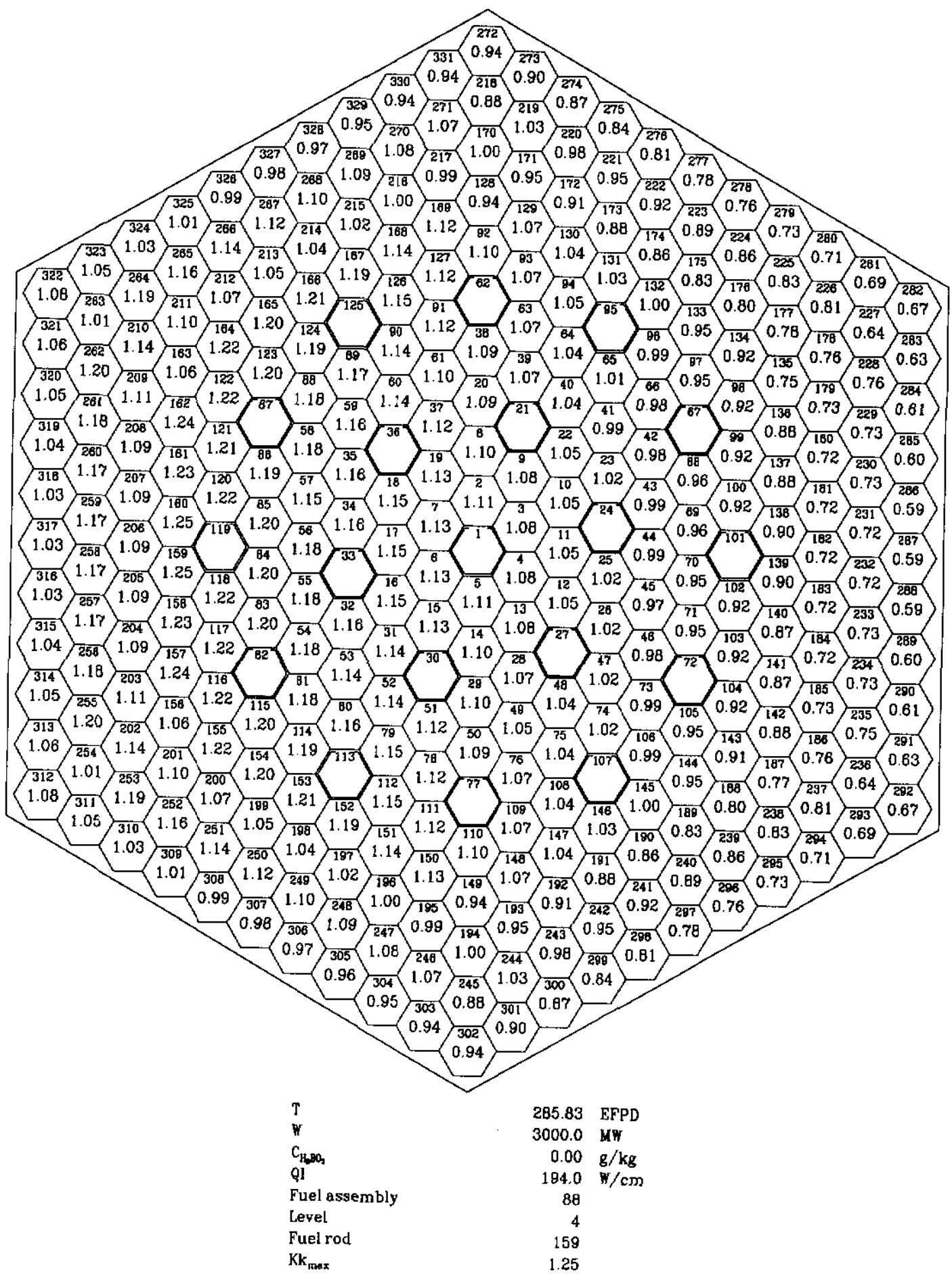


Fig.4.18. Assembly-by-Assembly Power Distribution.

Second Cycle with 3 MOX "100\%Pu" MOX LTAs

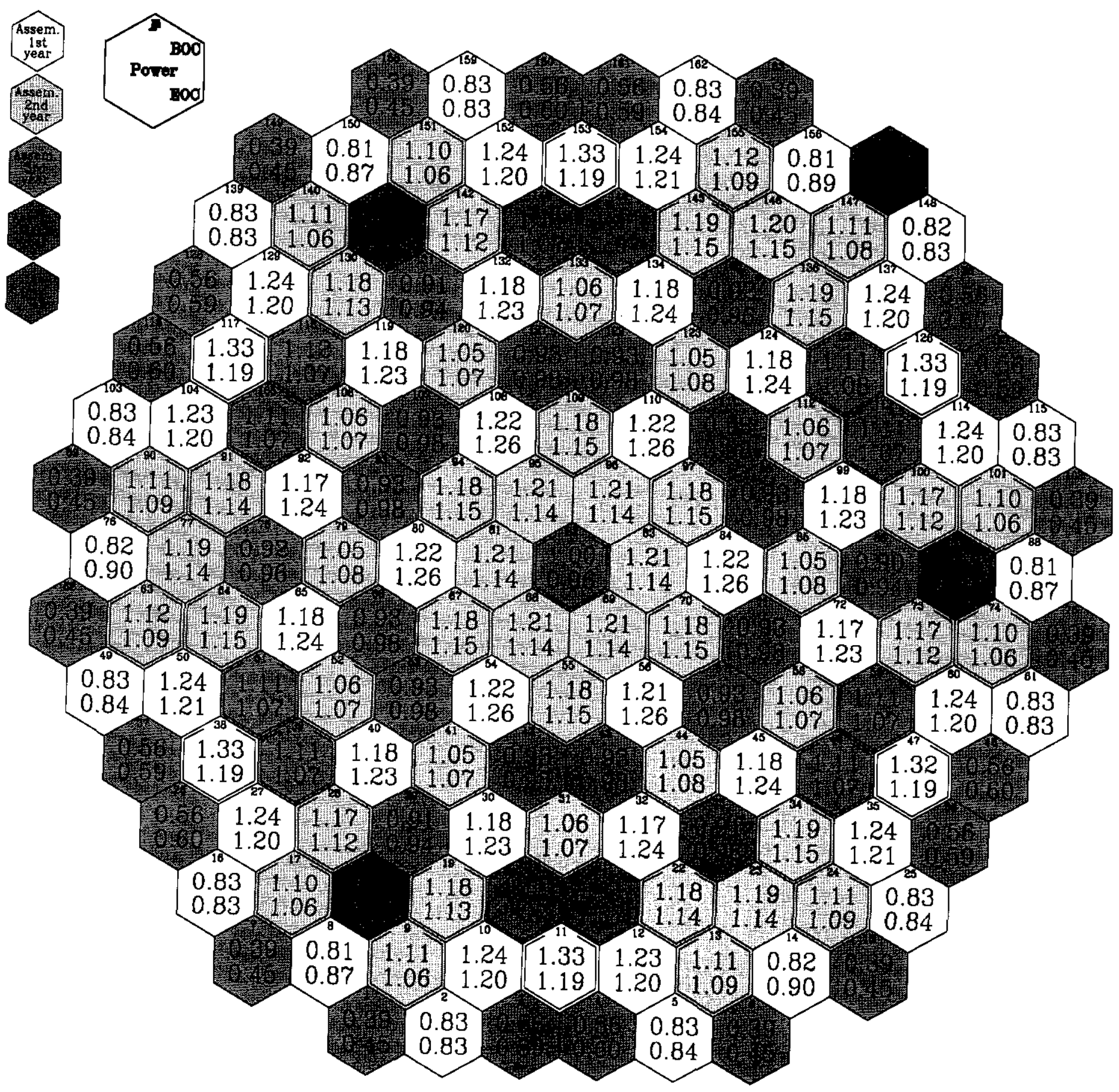


Fig.4.19. Assembly-by-Assembly Burnup Distribution.

Second Cycle with 3 "100\%Pu" MOX LTAs

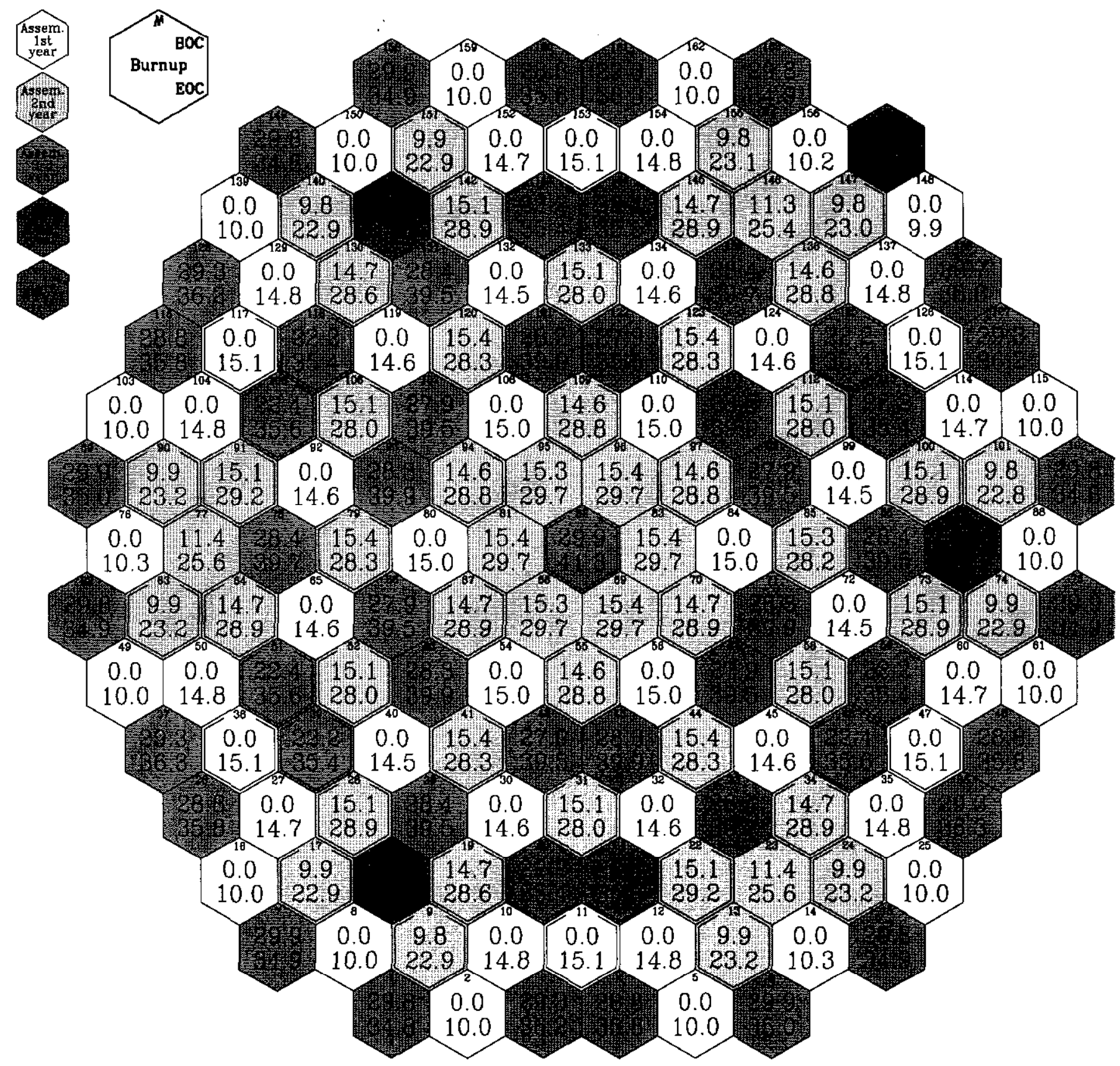


Fig.4.20. Assembly-by-Assembly Temperature Drop Distribution.

Second Cycle with 3 MOX "100\%Pu" MOX LTAS

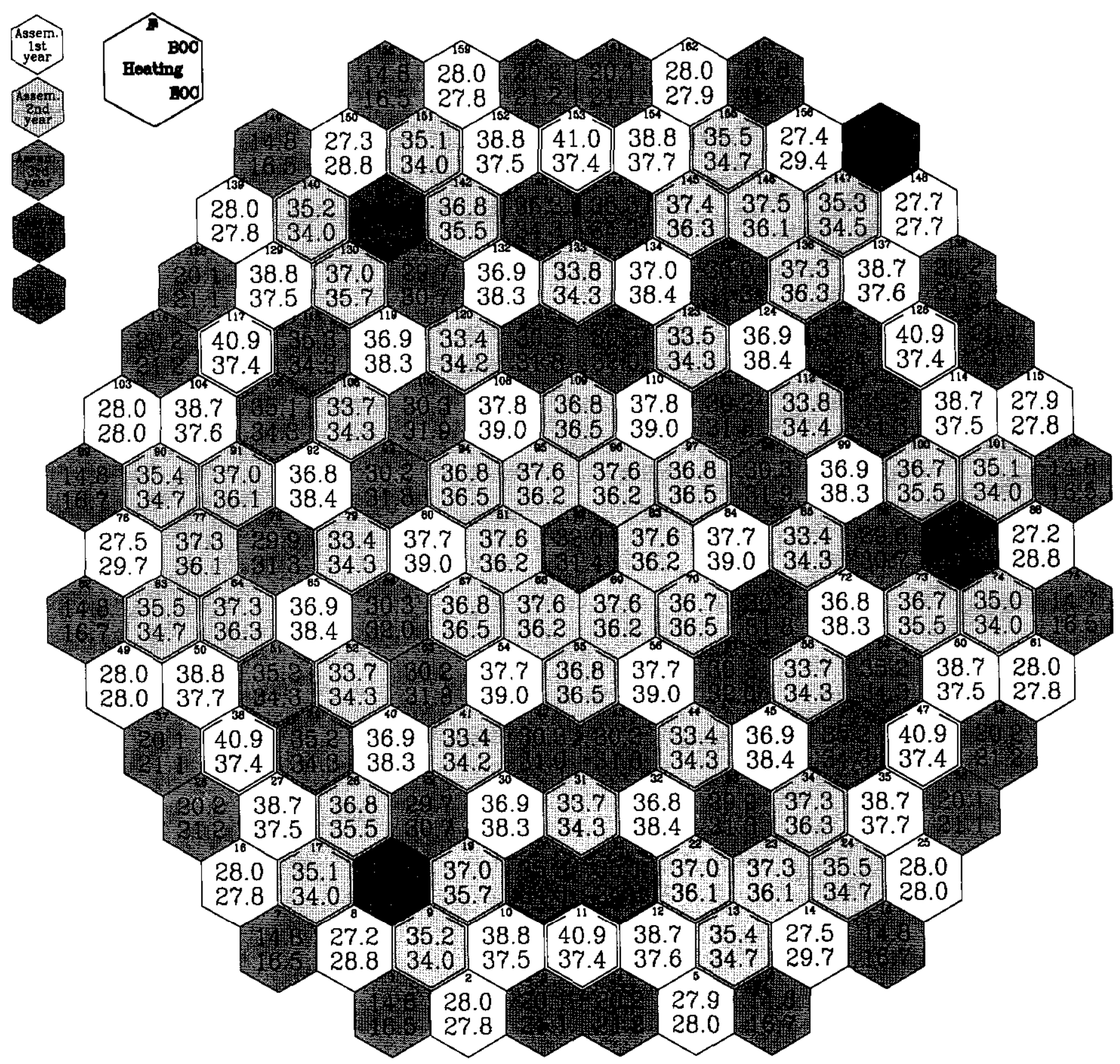


Fig.4.21. Assembly-by-Assembly Maximum Linear Pin Power Distribution in BOC. Second Cycle with 3 "100\%Pu" MOX LTAS

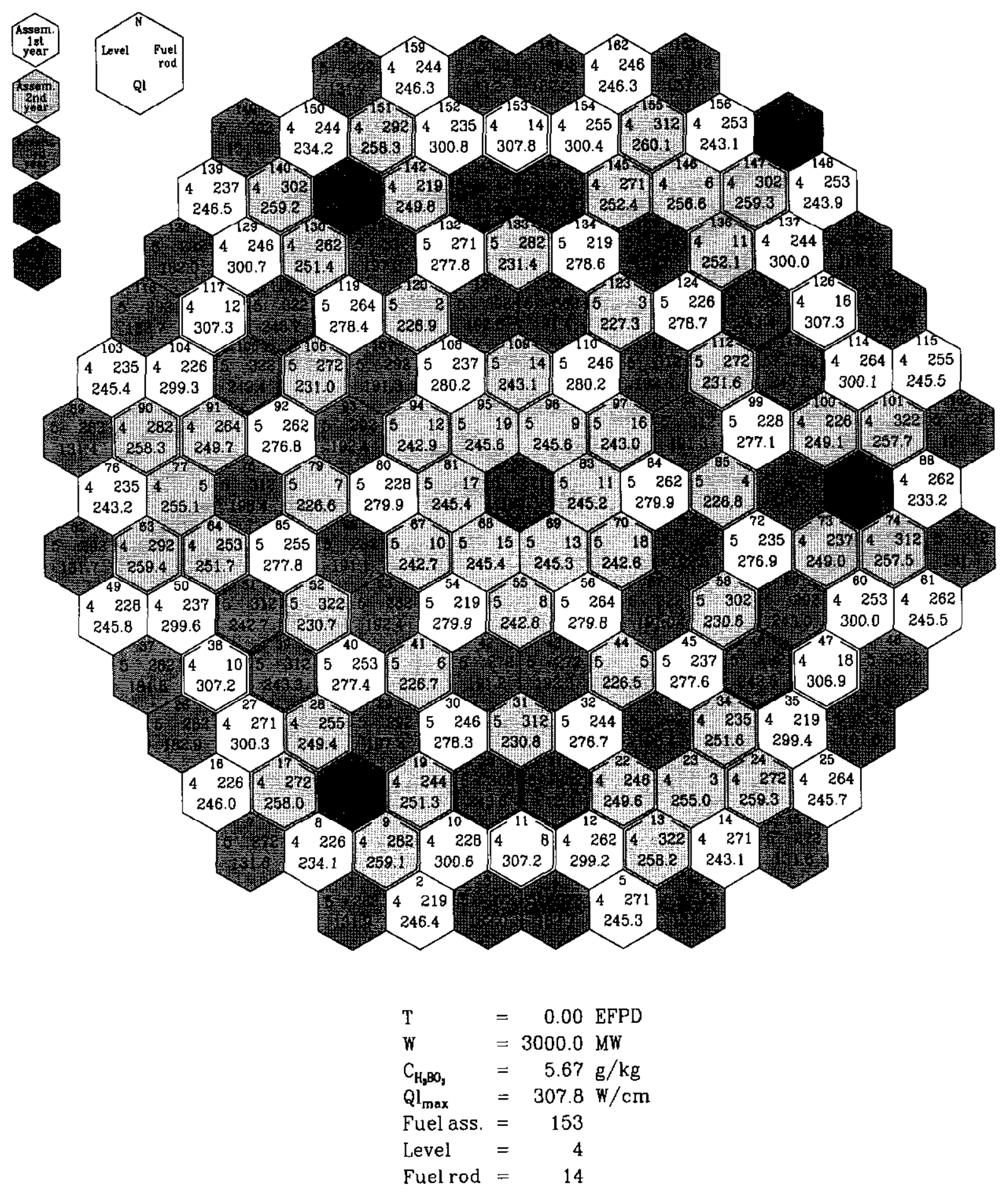


Fig.4.22. Assembly-by-Assembly Maximum Linear Pin Power Distribution in EOC. Second Cycle with 3 "100\%Pu" MOX LTAs

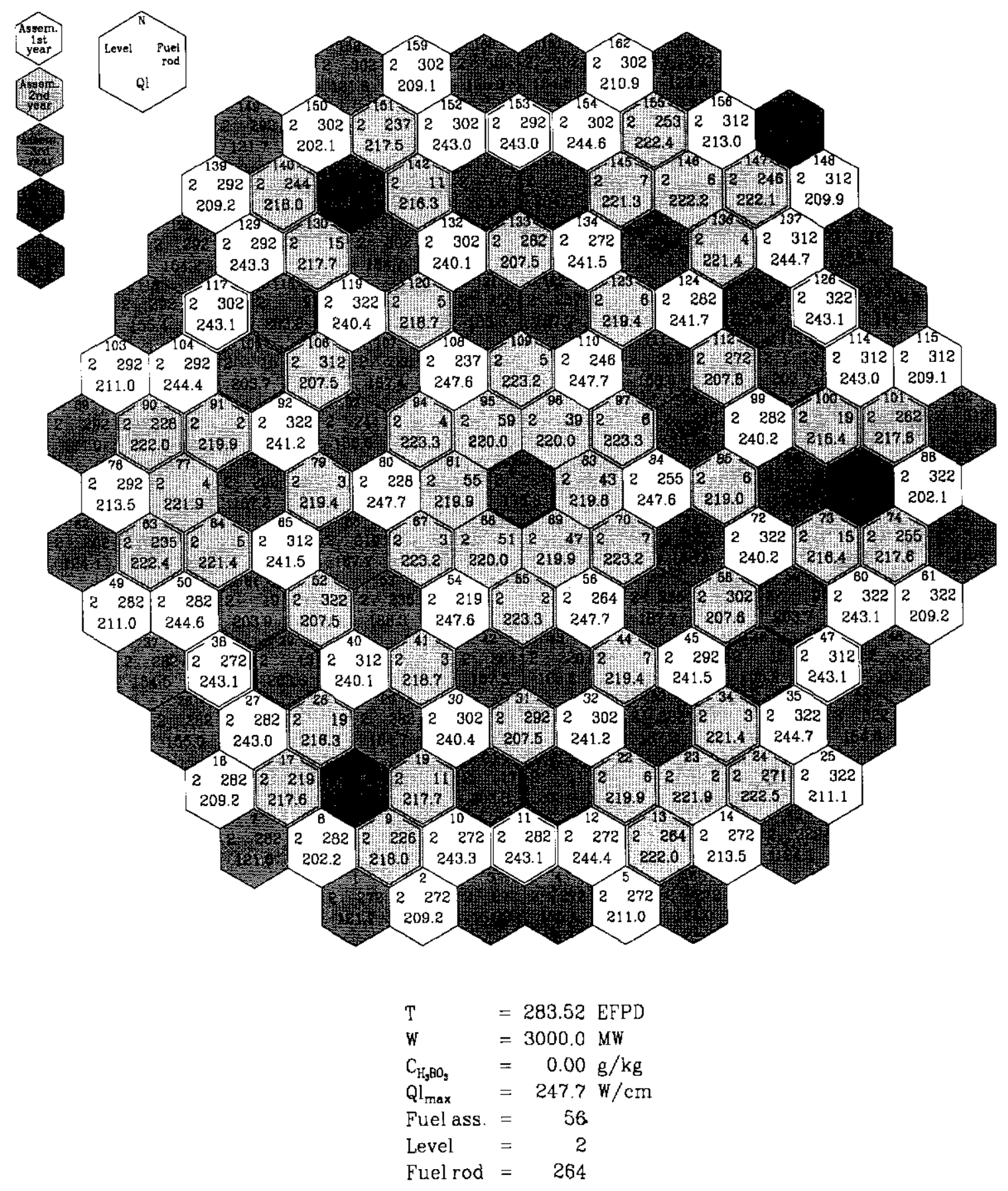


Fig.4.23. Pin-by-Pin Power Distribution in the Most Powered Assembly in BOC. Second Cycle with 3 "100\%Pu" MOX LTAs

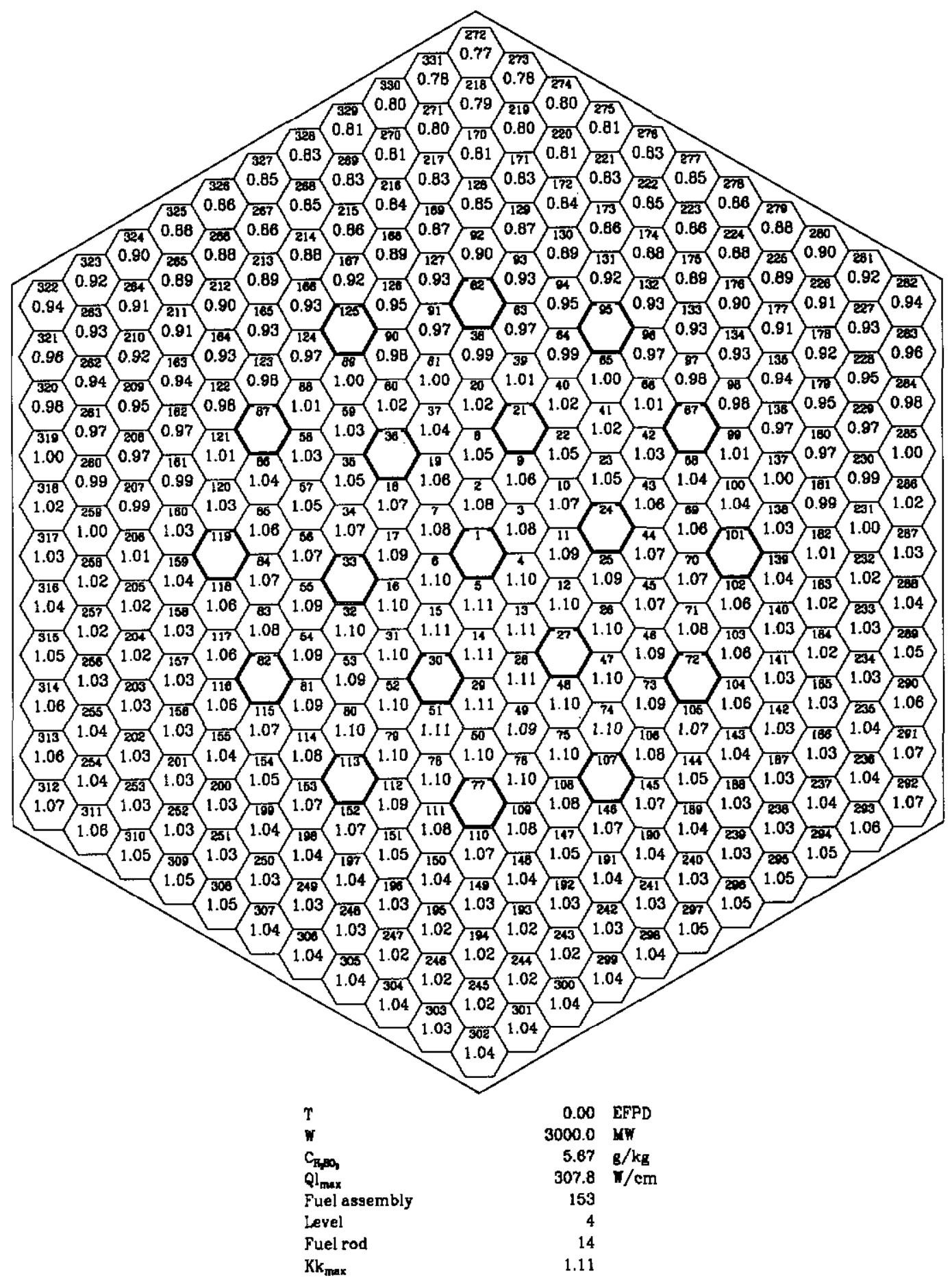


Fig.4.24. Pin-by-Pin Power Distribution in the Most Powered Assembly in EOC. Second Cycle with 3 "100\%Pu" MOX LTAs

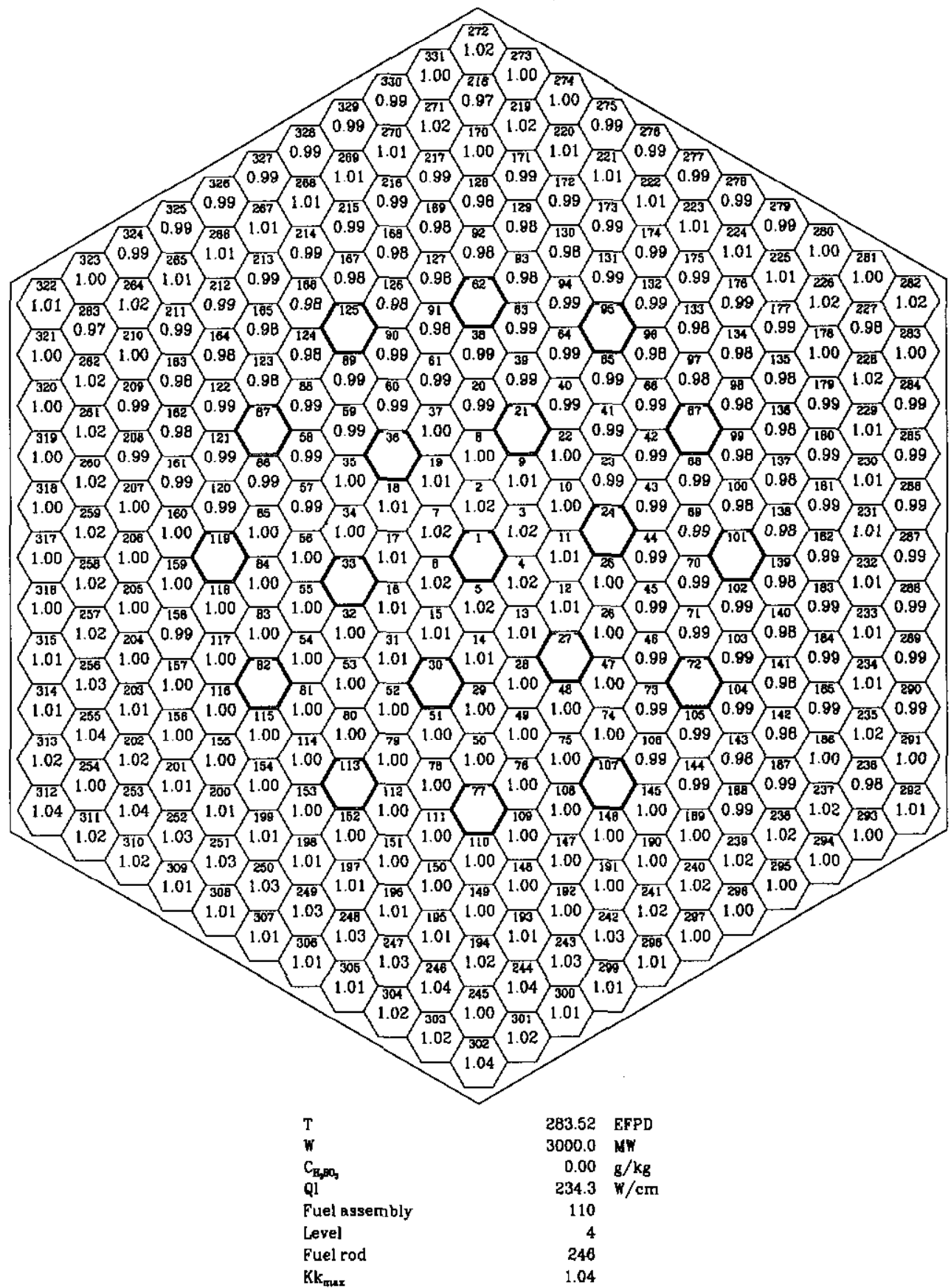


Fig.4.25. Pin-by-Pin Power Distribution in MOX LTA in BOC. Second Cycle with 3 "100\%Pu" MOX LTAS

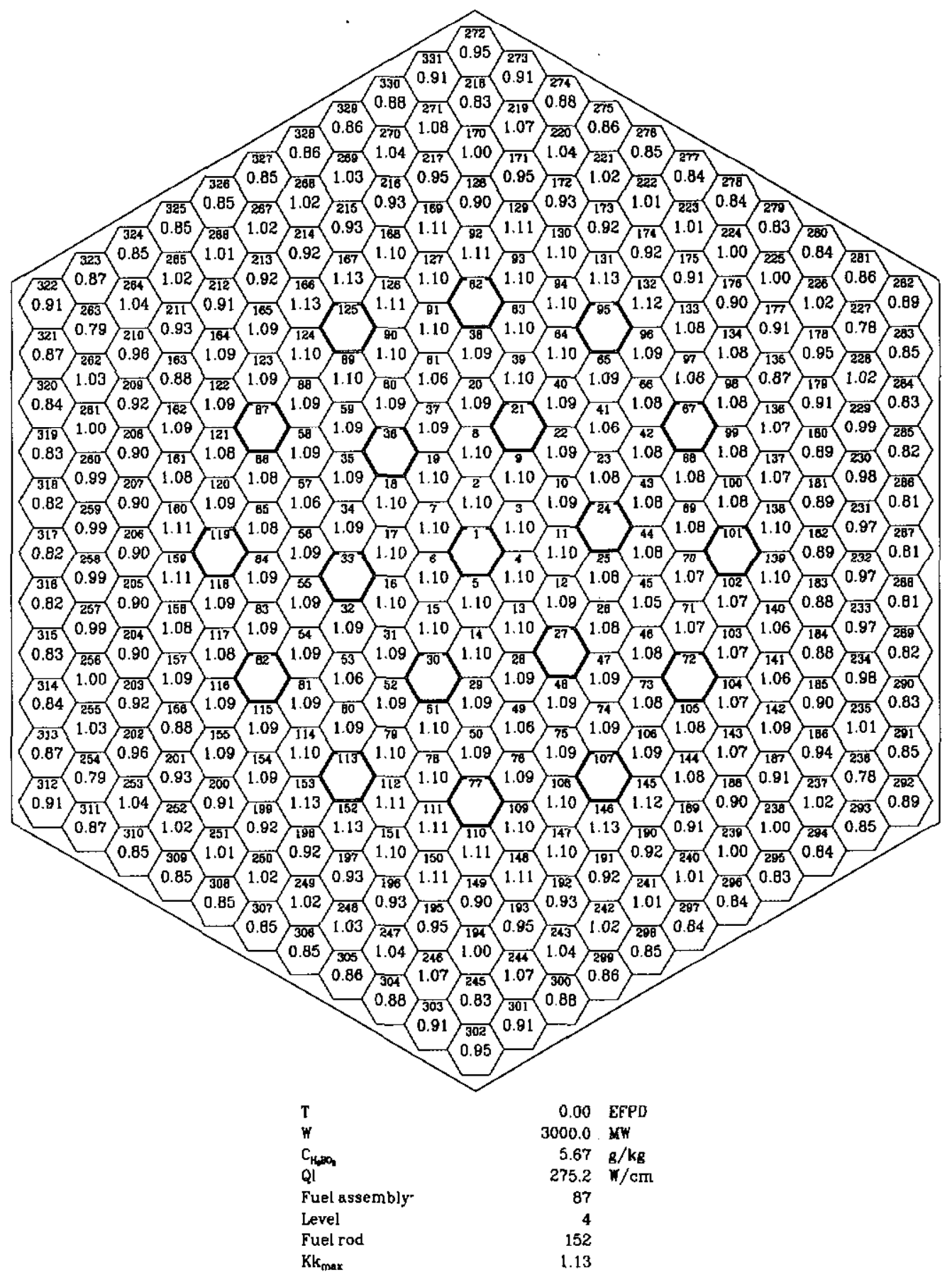


Fig.4.26. Pin-by-Pin Power Distribution in MOX LTA in EOC. Second Cycle with 3 "100\%Pu" MOX LTAS

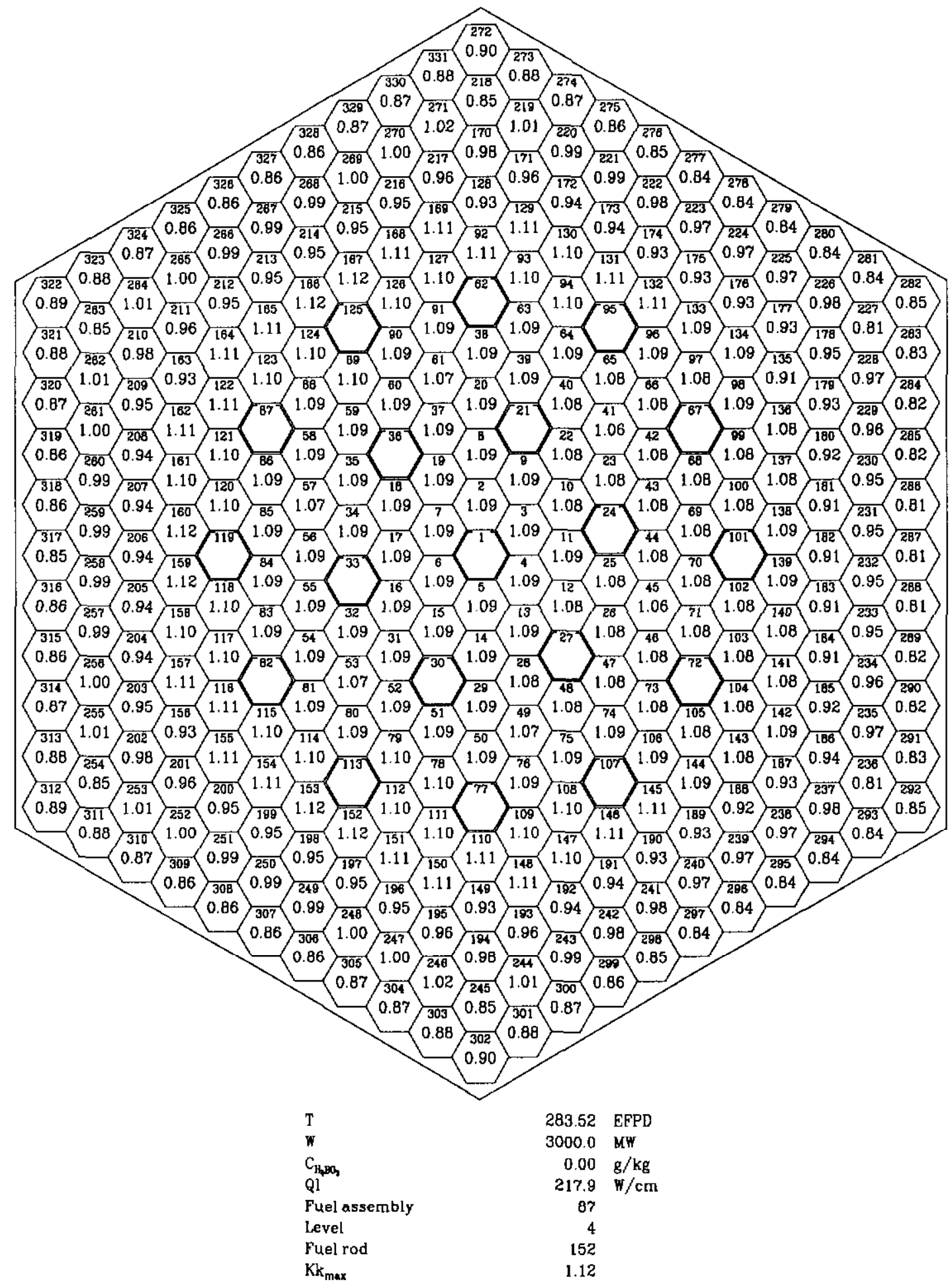


Fig.4.27. Reloading scheme.

Third Cycle with 3 MOX LTAs

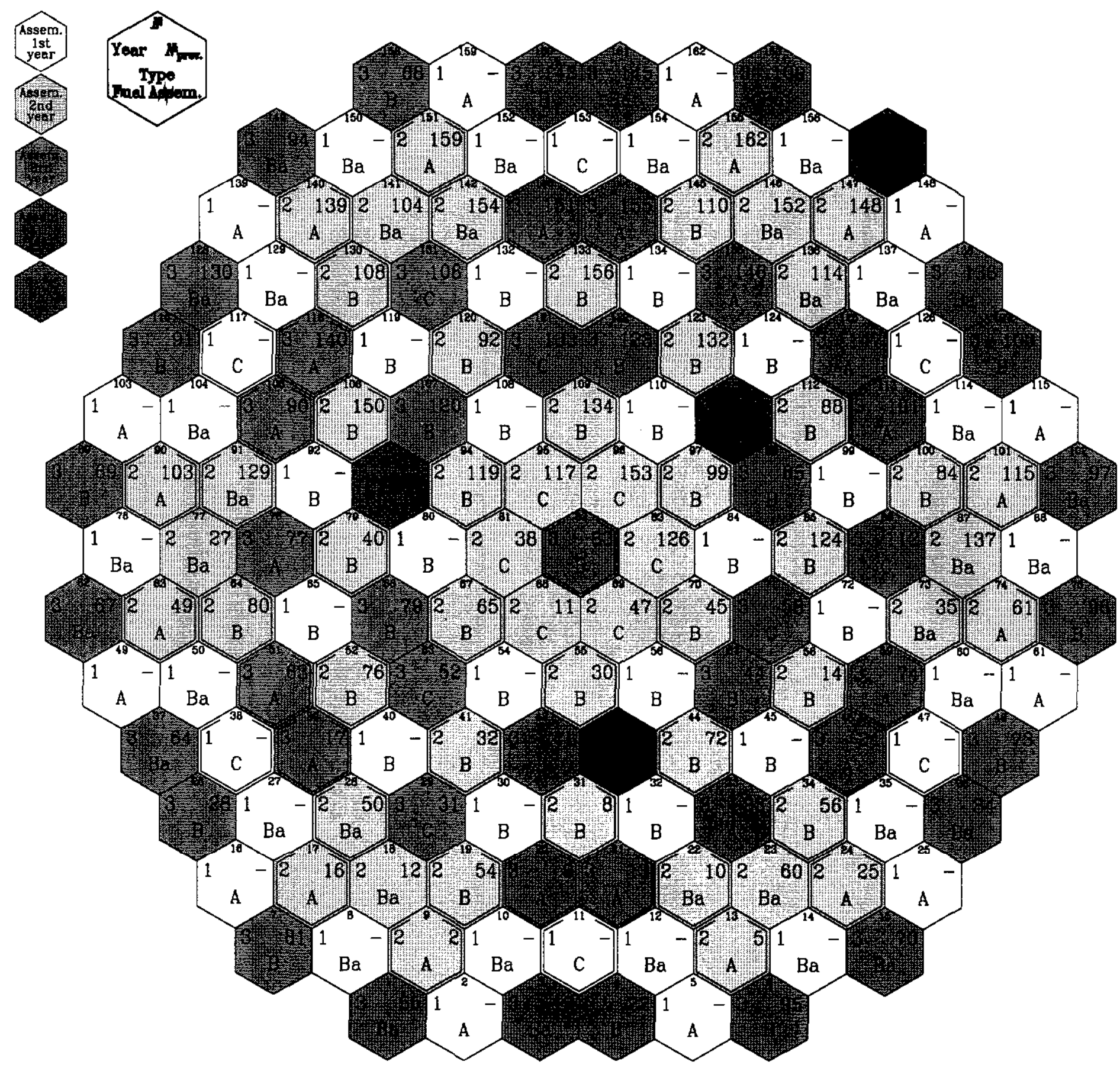


Fig.4.28. Assembly-by-Assembly Power Distribution.

Third Cycle with 3 "100\%Pu" MOX LTAs

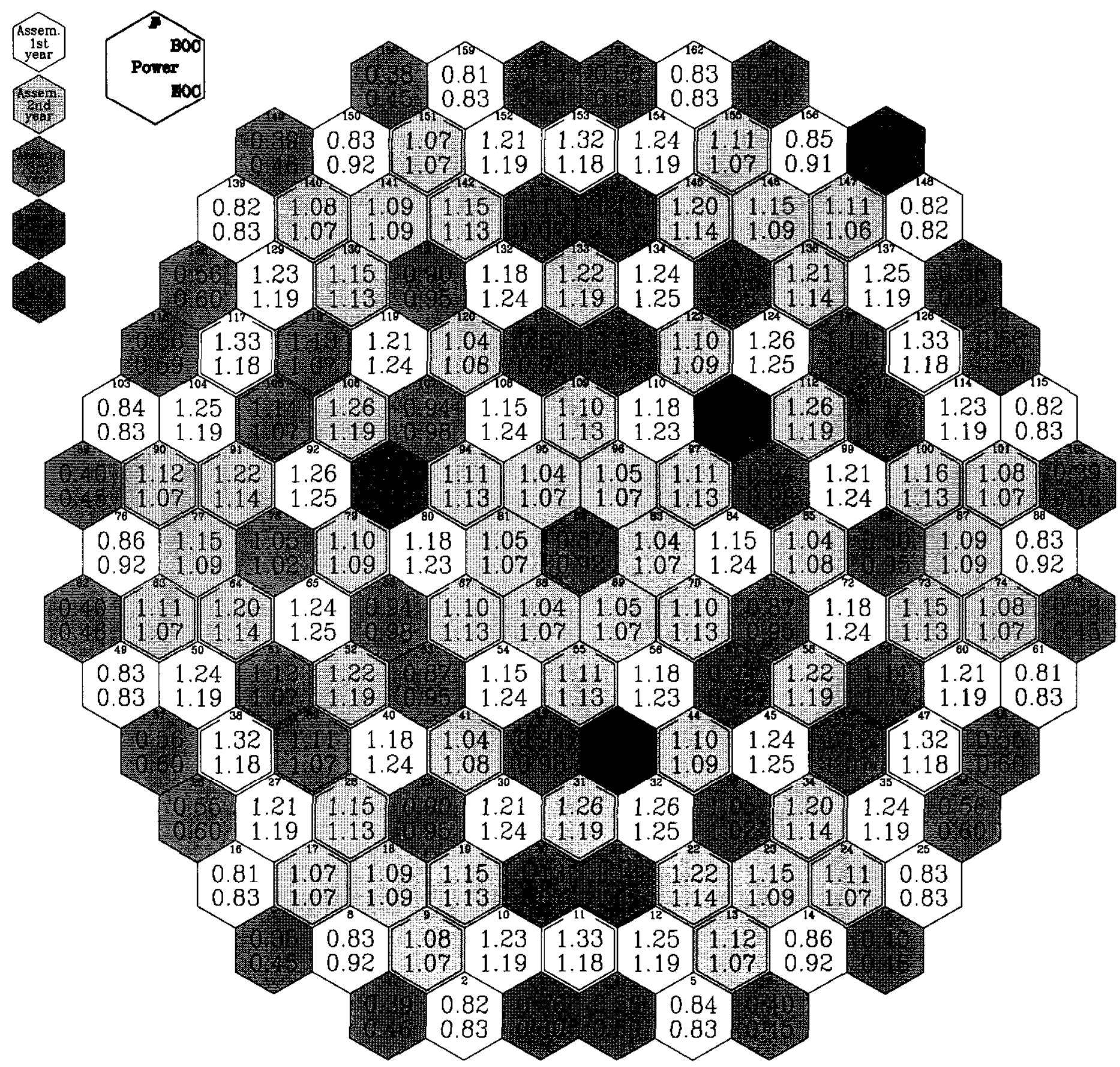


Fig.4.29. Assembly-by-Assembly Burnup Distribution.

Third Cycle with 3 "100\%Pu" MOX LTAs

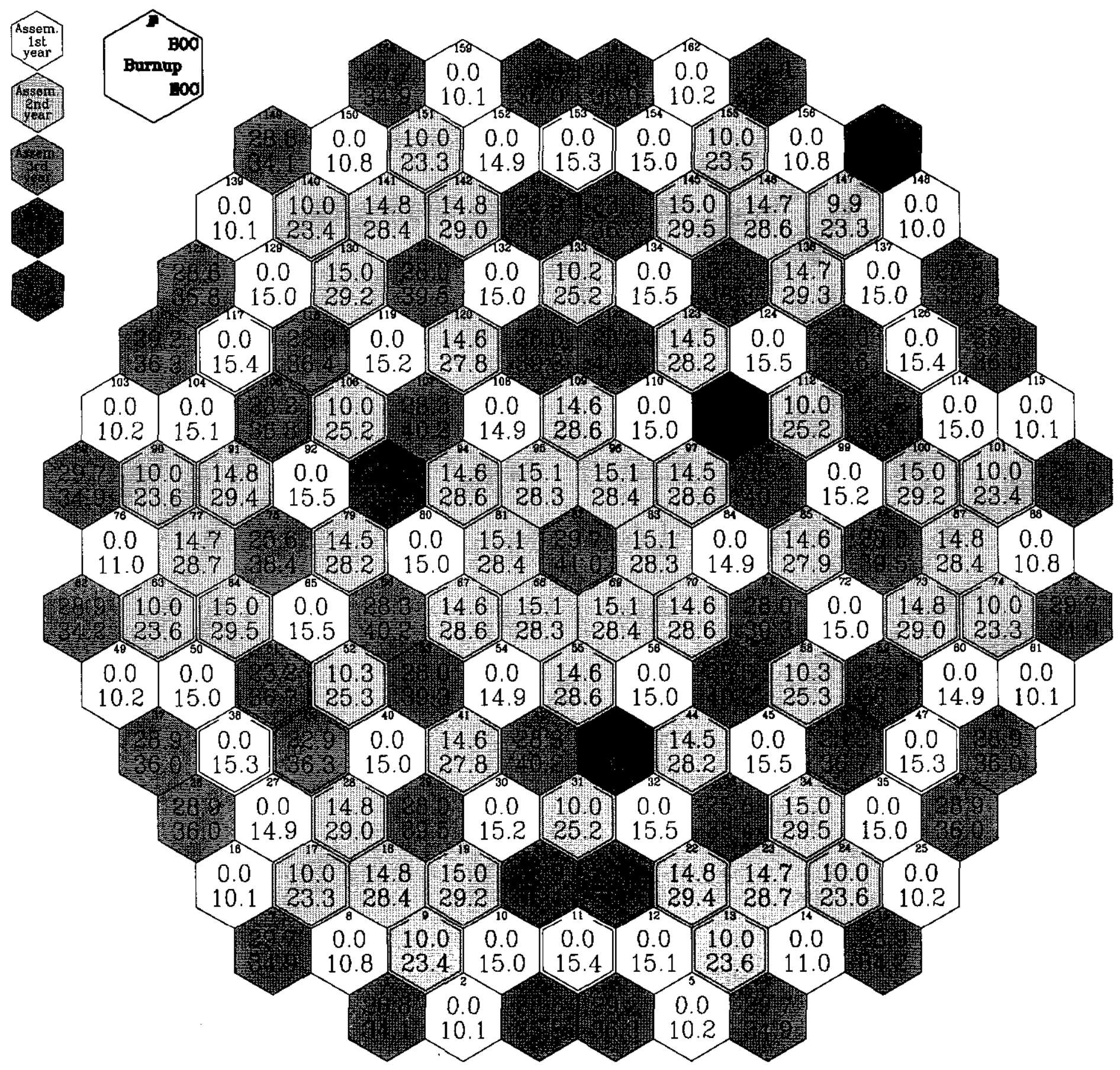


Fig.4.30. Assembly-by-Assembly Temperature Drop Distribution. Third Cycle with 3 "100\%Pu" MOX LTAs

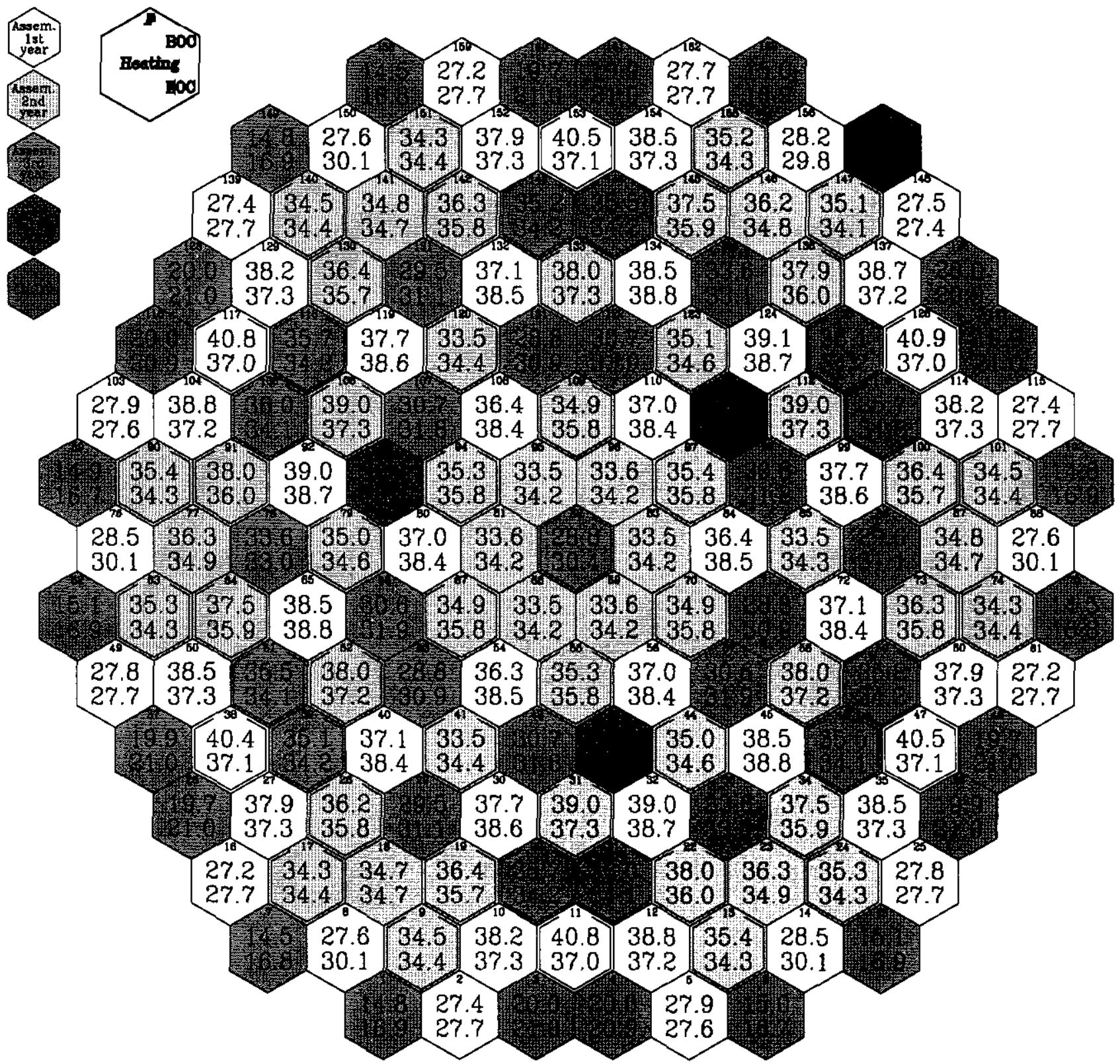


Fig.4.31. Assembly-by-Assembly Maximum Linear Power Distribution in BOC. Third Cycle with 3 "100\%Pu" MOX LTAs

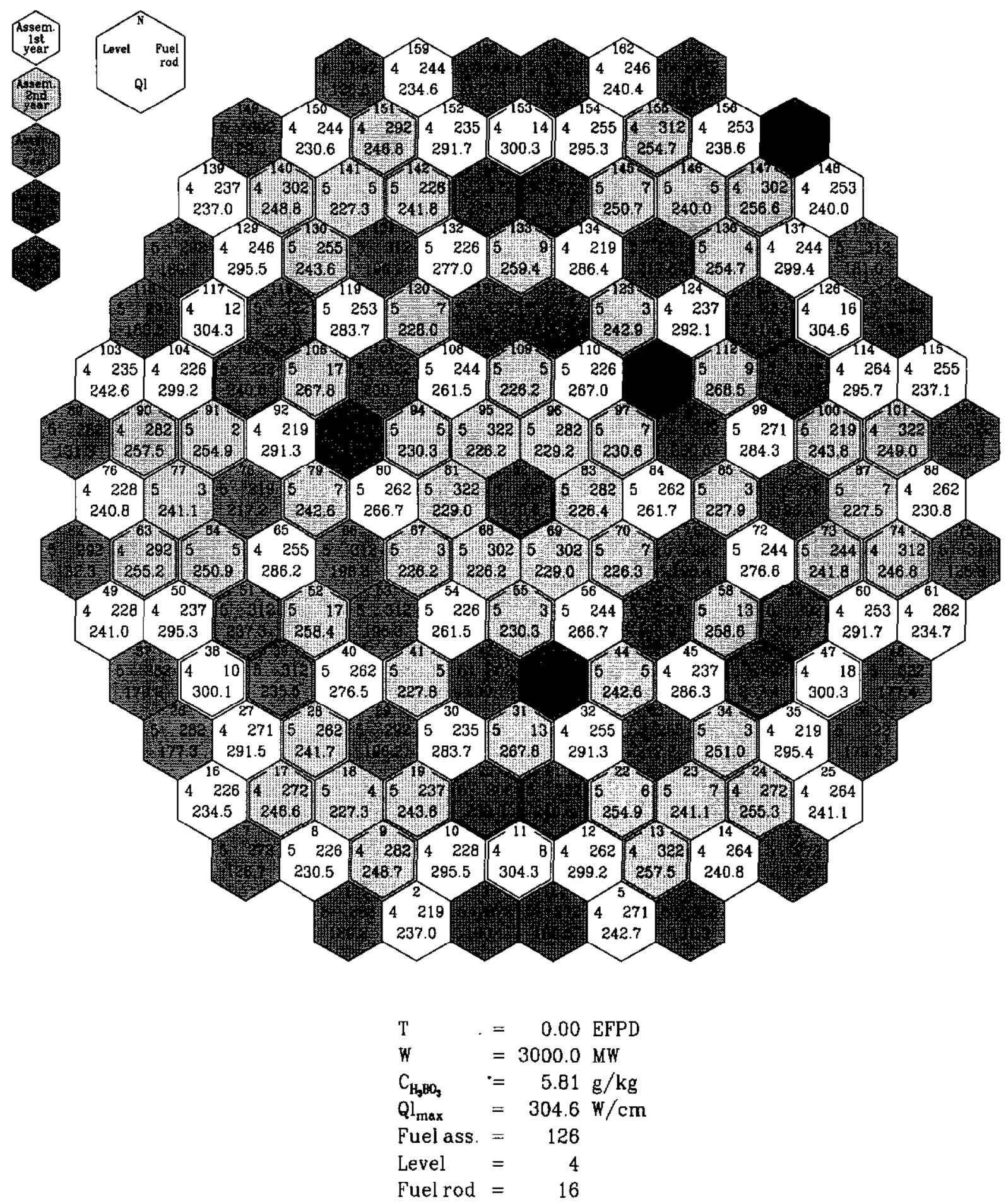


Fig.4.32. Assembly-by-Assembly Maximum Linear Power Distribution in EOC. Third Cycle with 3 "100\%Pu" MOX LTAs

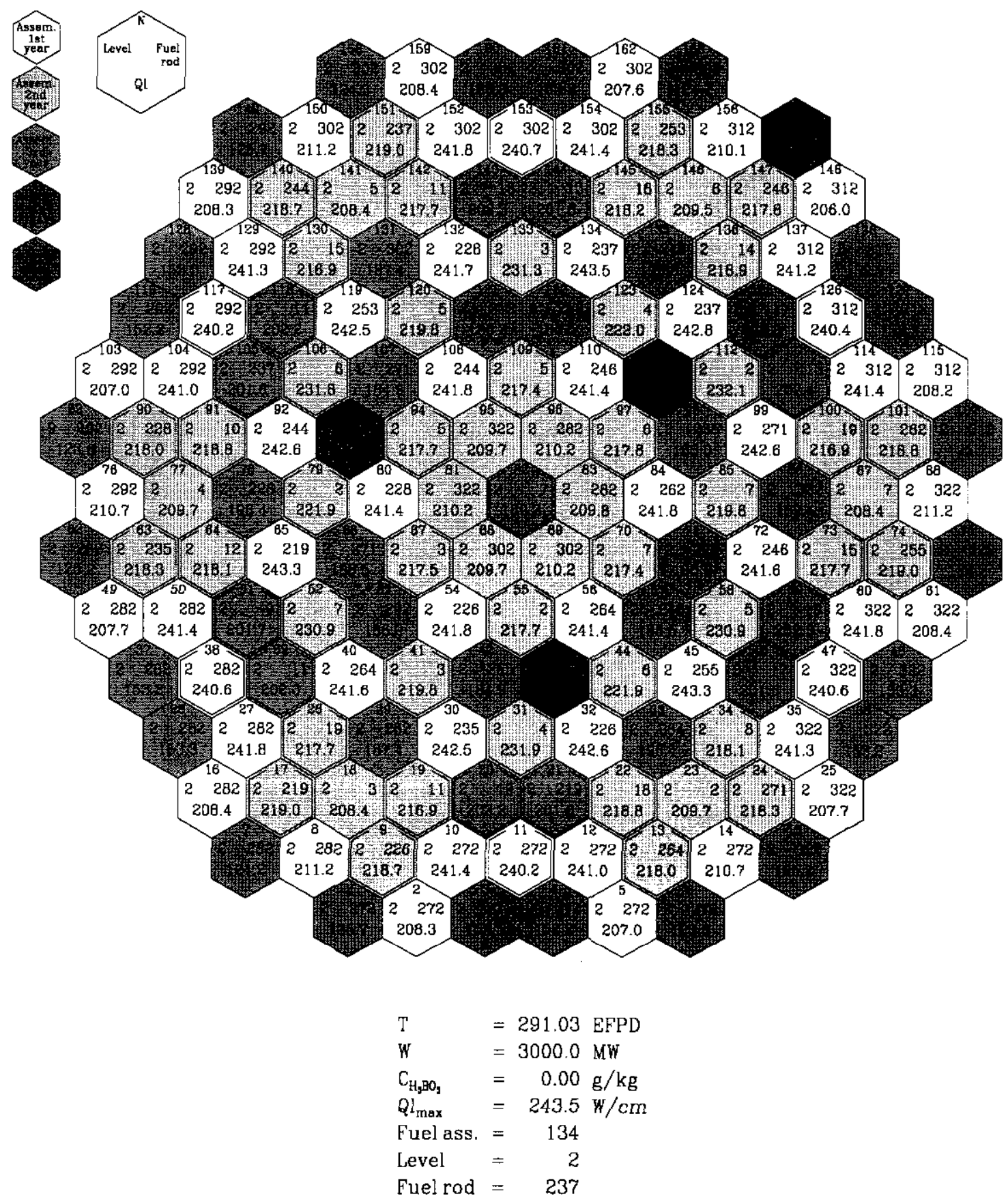


Fig.4.33. Pin-by-Pin Power Distribution in the Most Powered Assembly in BOC. Third Cycle with 3 MOX LTAs

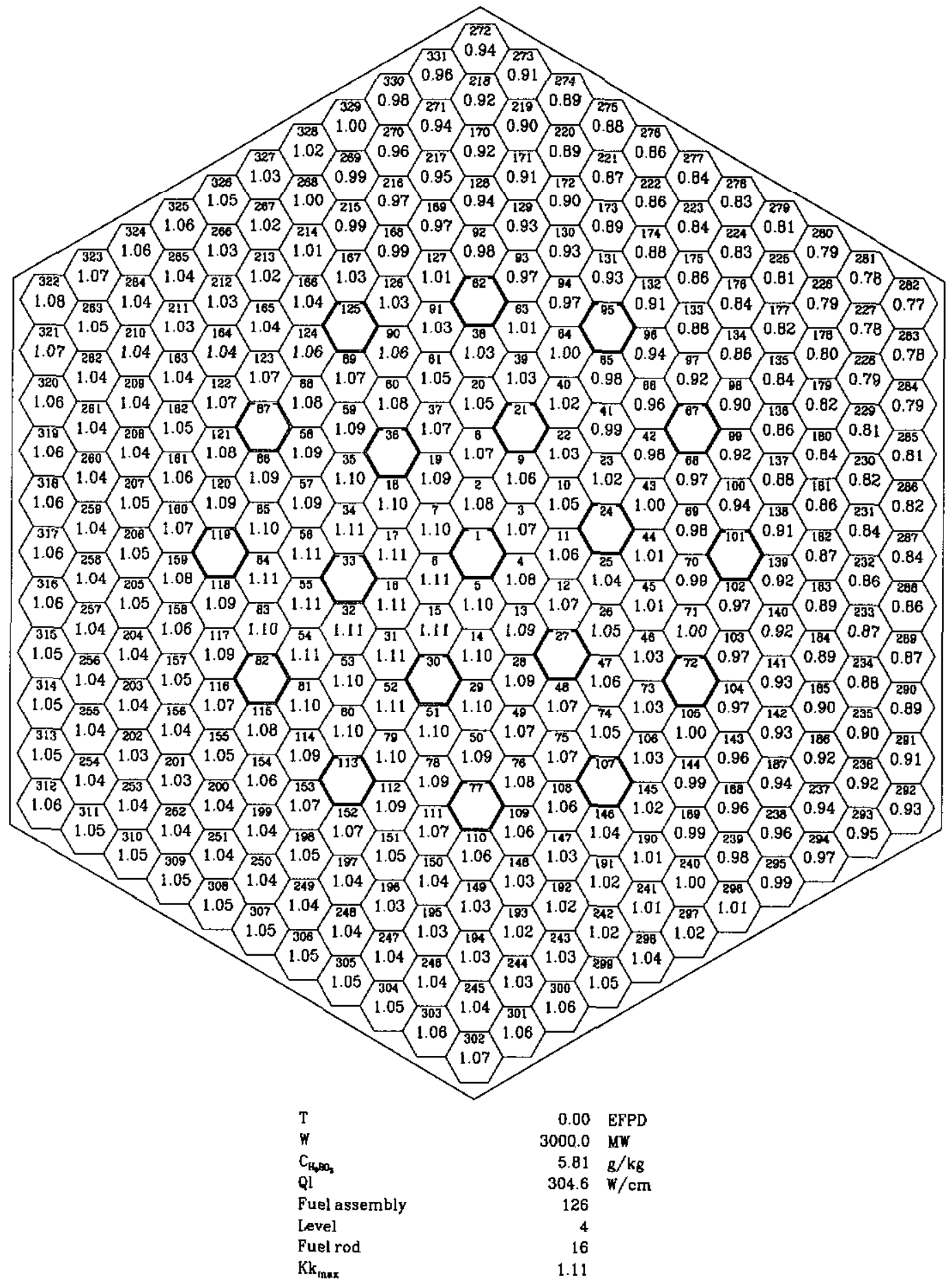


Fig.4.34. Pin-by-Pin Power Distribution in the Most Powered Assembly in EOC. Third Cycle with 3 " $100 \%$ Pu" MOX LTAs

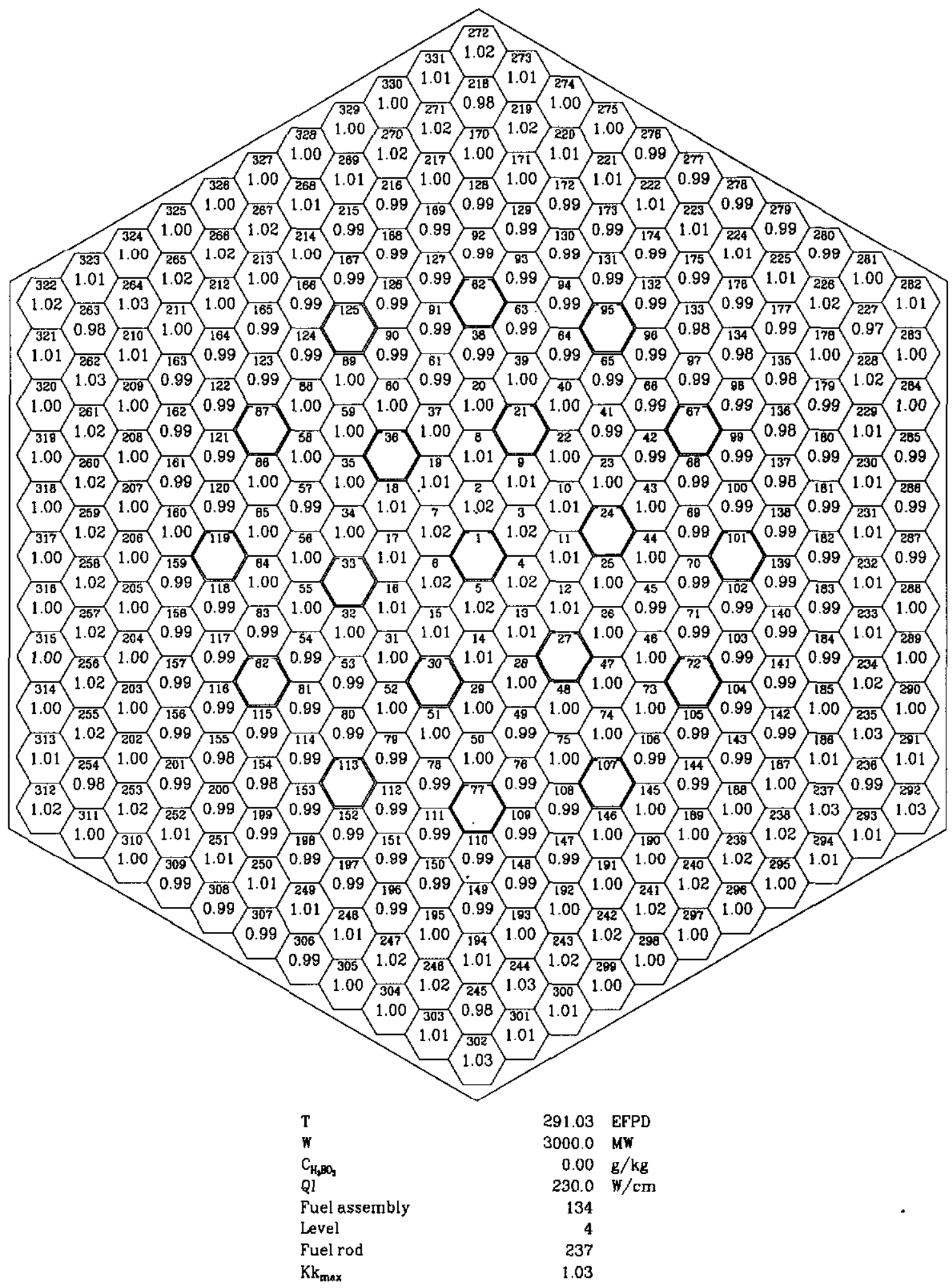


Fig.4.35. Pin-by-Pin Power Distribution in MOX LTA in BOC. Third Cycle with 3"100\%Pu" MOX LTAs

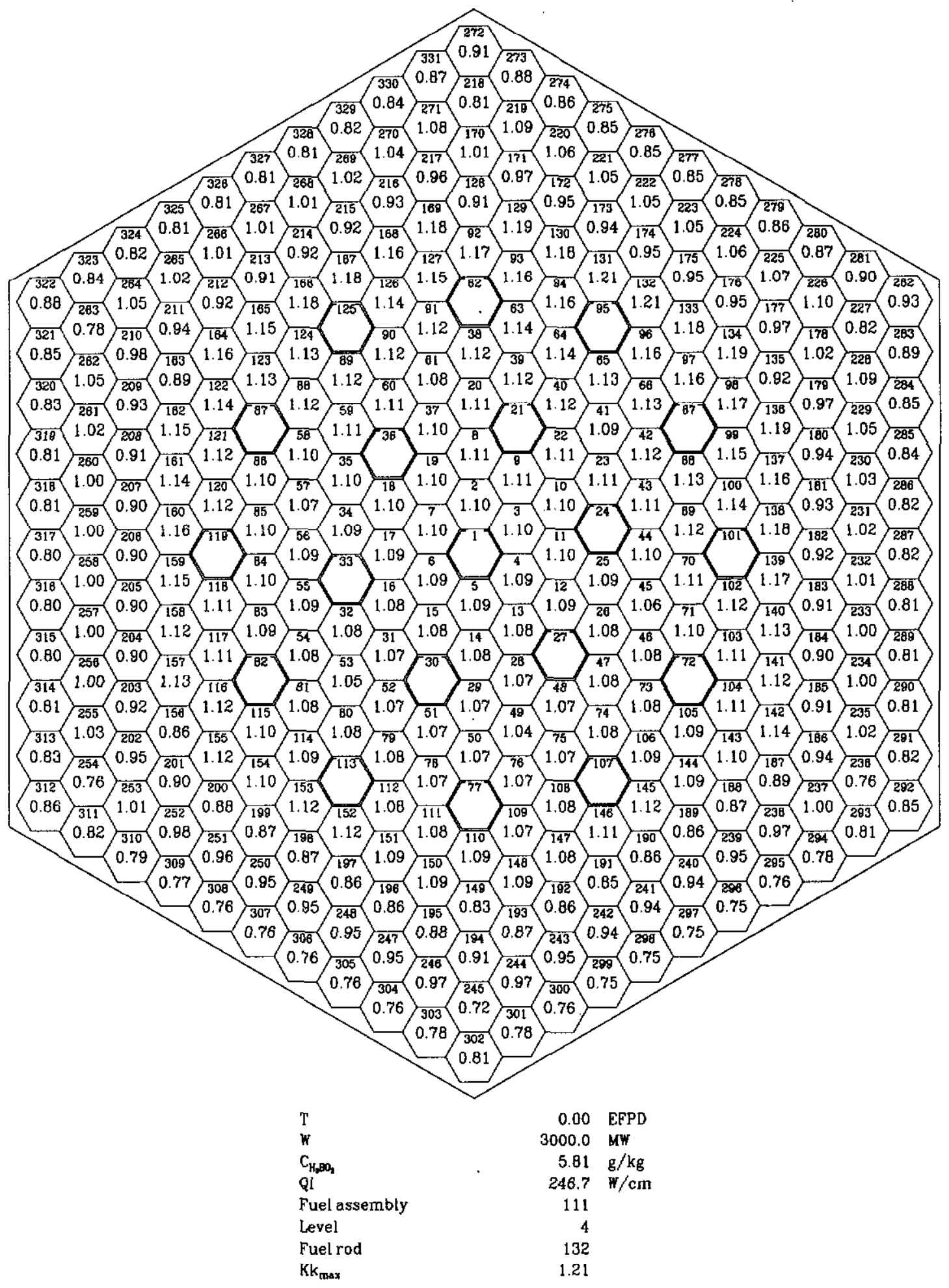


Fig.4.36. Pin-by-Pin Power Distribution in MOX LTA in EOC. Third Cycle with 3 MOX LTAs of "Island-2» Type (Pu3.8-2.8-U3.7)

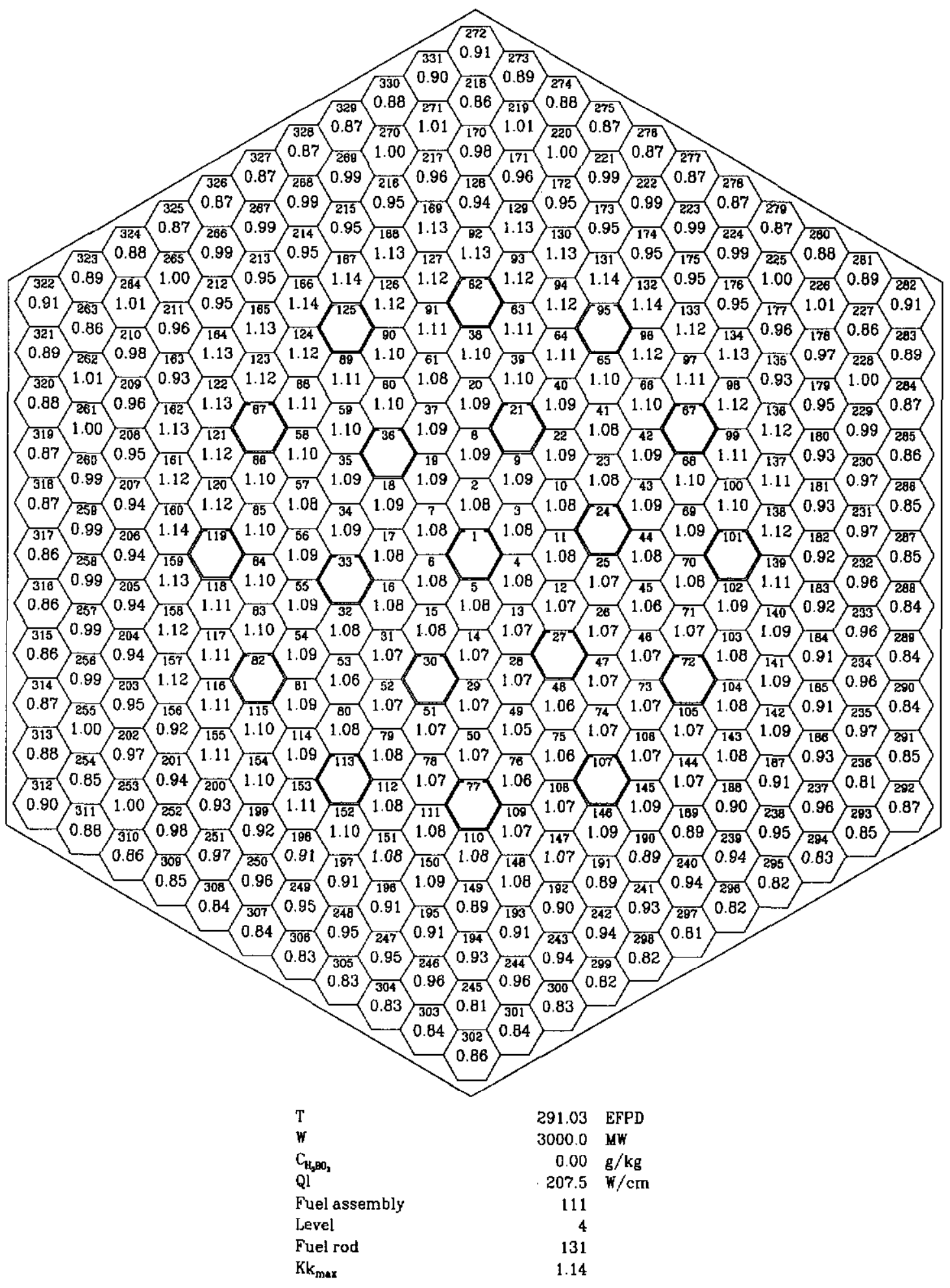




\section{A.1. Cell Code TVS-M}

\section{Nuclear data libraries}

The nuclear data library is based on the same files of estimated nuclear data as precision code MCU-RFFI [1*], which uses the Monte Carlo method.

In the epithermal energy region $(\mathrm{E}>0.625 \mathrm{eV})$ the calculation is based on slightly modified microcross section library BNAB (see, e.g., [2]) with 24 energy groups. The nuclide libraries can contain both the group and subgroup constants and for some nuclides with temperature dependence.

For the calculation of neutron spectrum in the energy region of resolved resonances $E_{n}<1 \mathrm{keV}$ ( 15 and higher $\mathrm{BNAB}$ group) the library includes files of resonance parameters of individual nuclides obtained on the base of the LIPAR library. For all fissile nuclei the library contains prompt and delayed neutron spectra, group $\beta$ values and decay constants for six groups of delayed neutrons.

The thermal energy region is divided into 24 groups. For the nuclides with the " $1 / \mathrm{v}$ " cross-section behavior the absorption cross sections at $2200 \mathrm{~m} / \mathrm{s}$ are used, for the rest ones the group values of the absorption, scattering and fission cross sections are specified. In addition, for oxygen and carbon the scattering matrices obtained in terms of gas model at 300,373, 473, 558,623K are given. For hydrogen bonded in water molecule the scattering matrix is obtained from the ENDF/B recommended data in terms of the Koppel model [3] at the same temperatures.

The library contains the files of cross sections and yields of 98 fission products including ${ }^{135} \mathrm{Xe}$ and ${ }^{149} \mathrm{Sm}$. The files of fission product yields are based on the ENDF/BVI data [4].

\section{Uniform lattice}

In the energy region of epithermal neutrons $\left(10.5 \mathrm{MeV}<\mathrm{E}_{\mathrm{n}}<0.625 \mathrm{eV}\right.$, BNAB groups 1-24) a detailed calculation of group spatial-energy distribution of neutron flux is performed. Each group is divided into an arbitrary number of intervals equal in lethargy, and then the calculation is performed at each point of group division. The of elastic scattering process is calculated without use of any approximations when the scattering is isotropic in the inertia center system (i.e.s), otherwise the scattering anisotropy is taken into account by the term not higher than linear in cosine of scattering angle. The slowing down due to inelastic scattering is taken into account via the matrix of inelastic transitions under the assumption of uniform energy distribution of neutrons scattering into the given group.

For nuclides with the subgroup description of cross sections the heterogeneous subgroup calculation of their micro cross sections is performed.

\footnotetext{
${ }^{*}$ References in p.A.1 are placed in the end of A.1
} 
In the energy region of resolved resonances (groups 13-24 BNAB) for resonance nuclides the calculation of all types of cross sections is performed with the use of nuclide resonance parameters. In so doing it is possible to take into account temperature dependence of resonance cross sections.

In the thermal energy region the standard calculation technique is used. It suggests solving the multigroup equation of thermalization with the neutron sources from the epithermal energy region formed when calculation for this energy range was performed.

Calculation of neutron spatial distribution is carried out by dividing the cells into an arbitrary number of annular material zones and by the use of the passing through probability (PTP) method [5]. In the calculation the actual form of the cell boundary is taken into account.

The calculation of the point kinetics parameters $\beta_{\text {eff. }} \ell$ is made by the standard formulas using the value function $\psi$ with respect to $K_{\text {eff }}$ and with six groups of delayed neutrons.

The calculation of the fuel nuclide composition during fuel burnup is performed for heavy nuclides from ${ }^{232} \mathrm{Th}$ to ${ }^{244} \mathrm{Cm}$ and for 98 fission products from ${ }^{82} \mathrm{Kr}$ to ${ }^{163} \mathrm{Dy}$. The burnup equations can be solved both by the Runge-Kutt method and by a faster analytical method described in [6].

\section{Calculation of supercells and fuel assemblies}

For the determination of FA neutronic characteristics the code uses the diffusion fine-mesh calculation with an arbitrary number of groups from 4 to 48 and with the mesh width equal to the pitch between fuel rods in the FA. For the boundary mesh cells the compression coefficient is used. Along with the standard six-point scheme the refined scheme whose principles of construction are described in [7] can be used. The mesh equation has a common form however the quantities in this formula have another sense, namely:

$$
\begin{array}{rlrl}
\frac{4}{3 a^{2}} \sum_{i=i}^{6} \frac{d_{0} d_{i}}{d_{0}+d_{i}}\left(F_{0}-F_{i}\right)+ & \left(\Lambda_{0}^{a}+\Lambda_{0}^{r}+G_{0}^{Z} B_{z}^{2}\right) F_{0}=S_{0} \\
F=\varepsilon \Phi & \Lambda & =\Sigma / \varepsilon \\
G^{Z}=D^{Z} / \varepsilon & d & =D^{R} \xi \\
\varepsilon & =\psi(1-\gamma / \delta) & \delta & =2 d / a
\end{array}
$$

In formulas (2-7) $\Phi$ is the cell neutron flux; the sense of quantities $\Sigma, D^{R}, D^{Z}$ is obvious. Then

$$
\psi=\frac{\Phi_{b}^{s}}{\bar{\Phi}^{s}} \quad \xi=\frac{j_{b}^{a}}{\bar{j}^{a}}
$$

Here $\Phi$ is the neutron flux in the given mesh cell; $j$ is the neutron current in the cell; index " $b$ " means the value of corresponding quantity at the cell boundary; index " $s$ " indicates the solution of transport equation in the cell with symmetric boundary conditions (symmetric inflowing and outflowing neutron current); index " $a$ " is the solution with asymmetric boundary conditions (neutron current flowing through the cell); the bar shows the quantity value averaged over the cell. 
The use of these quantities permits joining of accurate (i.e. obtained from solving of transport equation for the cell) neutron flux and current at the cell boundary and keeping of the accurate connection between the solution of equation (1) and the reaction rates in the cell. In this way it becomes possible to avoid errors peculiar to the standard calculation scheme associated with the finite size and heterogeneous structure of mesh points. For solving the set of equations any modules of diffusion equation solutions can be used.

As usual the process of solving the diffusion equations is divided into the solving of the equation for each group and the determination of fission source by means of external iterations. If the state of FA at power is considered then upon their completion the external iterations are added with the calculation of ${ }^{135} \mathrm{Xe}$ and ${ }^{149} \mathrm{Sm}$ concentrations and a new iteration cycle.

Each mesh point pertains to a definite type: fuel rod, cell with absorber rod, cell corresponding the gap between FAs, etc. The constants for the background type are always calculated in the asymptotic mode, i.e. as for the uniform fuel cell. The constants for non-fuel cells are calculated in the mode of supercell. For the non-background fuel cells including those with integrated burnable poison (named tvegs) the calculation can be performed both in the asymptotic and supercell modes. The homogenized background cell is always considered as the external zone of supercell.

\section{References}

1. Gomin E.A., Majorov L.V. The MCU-RFFI Monte Carlo Code for Reactor Design Applications. Proc. of Int. Conf. on Math. and Comp., Reac. Phys. and Envir. Analyses, April $30-4$ May 1995, Portlend, Oregon, USA

2. L.P.Abagyan et al. Group constants for calculation of the reactors and shields. M., Energoizdat, 1981.

3. Koppel J.U., Houston S.H. Reference for ENDF Thermal Neutron Scattering Data, GA-8774, 1978

4. ENDF-102. Data Formats and Procedures for the Evaluated Nuclear Data Files ENDF-6, July 1990, National Nuclear Data Center, Brookhaven National Laboratory, Upton, NewYork, 11973

5. I.E.Rubin. Method of probabilities of transmission in the one-dimensional cylindrical geometry. Izvestiya AN BSSR, ser. fiz-energ. nauk, № 2, p. 25-31, 1983.

6. V.M.Kolobashkin et al. Radiation characteristics of irradiated nuclear fuel M., Energoatomizdat, 1983.

7. V.D.Sidorenko. Homogenization of effective cross sections in the periodic lattice. Preprint IAE-2793, 1977. 


\section{A.2. Coarse-Mesh Code BIPR-7A}

BIPR-7A is a 3-dimensional hexagonal coarse-mesh code intended to calculate neutronics characteristics of VVER-type reactor core.

Calculational cell represents assembly transversal section in horizontal plane and usually one-tenth of core height in axial direction i.e. there are 1630 cells in VVER-1000 core. Neutronics parameters are homogeneous within a cell.

Radial, upper and lower reflectors are described by border conditions.

Calculation is performed in two energetic groups using the so-called modal presentation of group fluxes [8].

Cell constants, prepared by the code TBC-M [4], form a library and represent a number of polynomials that reflect the two-group neutronics cross sections dependence on moderator density, moderator temperature, fuel temperature, FP concentrations in fuel, boron acid concentration in coolant, $\mathrm{Xe}$ and $\mathrm{Sm}$ concentration in fuel.

BIPR-7A is a part of industrial super-code KASKAD that allows obtaining in convenient formats all the parameters necessary for reactor safety estimations and licensing.

As a result BIPR-7A calculate the following parameters:

\begin{tabular}{|c|c|}
\hline & $\begin{array}{l}\mathrm{q}_{\mathrm{i}}, \\
\mathrm{Kq}, \\
\mathrm{q}_{\mathrm{ij}}, \\
\mathrm{Kv}, \\
\mathrm{BUi}, \\
\mathrm{BUij}, \\
\mathrm{MTC}, \\
\mathrm{MDC}, \\
\mathrm{DTC}, \\
\mathrm{DRO} / \mathrm{DCB}, \\
\beta \mathrm{eff}, \\
\lambda \mathrm{m}, \\
\mathrm{Cb} \text { CRIT, } \\
\text { RO } \\
(\mathrm{ROO}, \\
\mathrm{R}_{\mathrm{AP}} .\end{array}$ \\
\hline
\end{tabular}




\section{A.3. Fine-Mesh Code PERMAK-A}

PERMAK-A is a 2-dimensional fine-mesh code intended to calculate neutronics characteristics of VVER-type reactor core.

Calculational cell represents fuel pin-type hexagonal cell with homogeneous neutronics parameters within it.

Diffusion finite-differencies neutron balance equation in few energetic groups are resolved.

Radial reflector is described by the same manner as a core.

Neutron flux axial gradients, obtained by BIPR-7A, are used while calculating one (as usual) the most powered core axial level.

Cell (fuel and non-fuel) constants, prepared by the code TBC-M [4], form a special library and represent a number of polynomials that reflect the group neutronics cross sections dependence on moderator density, moderator temperature, fuel temperature, FP concentrations in fuel, boron acid concentration in coolant, Xe and Sm concentration in fuel.

PERMAK-A is a part of industrial super-code KASKAD that allows obtaining in convenient formats all the parameters necessary for reactor safety estimations and licensing.

As a result PERMAK-A calculates the following parameters:

- $\mathrm{q}_{\mathrm{k}}$,

- $\mathrm{Kk}$,

- $\mathrm{Kr}$;

- BUk,

- $\mathrm{Q}_{1}$

- $\mathrm{K}_{\mathrm{o} \text {-total. }}$ 


\section{A.4. Reflector Description}

The simplified structure of VVER-1000 radial reflector is presented in Fig. A.2.. In $\mathrm{KI}$ fine-mesh calculations by the code PERMAK-A the radial VVER-1000 reflector is modeled by "reflector assemblies" of five types (Figures A.1, A.3-A.7). Zero flux is applied on the outer reflector borders. The corresponding geometric condensation factors are applied to the cell types of reflector if the cells are situated in "reflector assembly" corners or on the borders.

The upper and lower reflectors can be described on the base of reactor core design presented in [1]. 


\section{Figure A.1. Equilibrium Loading Pattern for Base Uranium Core with Boron BPRs, Core $60^{\circ}$ Sector}

An - 3,7\% Enrichment graded by 3,3\% Replaced After 3 Years (No BPRs)

Bn - 3,7\% Enrichment graded by 3,3\% Replaced After 3/4 Years $(0,065 \mathrm{~g} / \mathrm{cc}$ Boron BPRs, removed after 1st year $)$

Cn - 3,3\% Enrichment Replaced After 3 Years (No BPRs)

1-28 - Positions in 60 Degree Sector n - Current Cycle of Fuel Assembly Symbol e.g. \$ - Position of a Fuel Assembly During Lifetime in Core

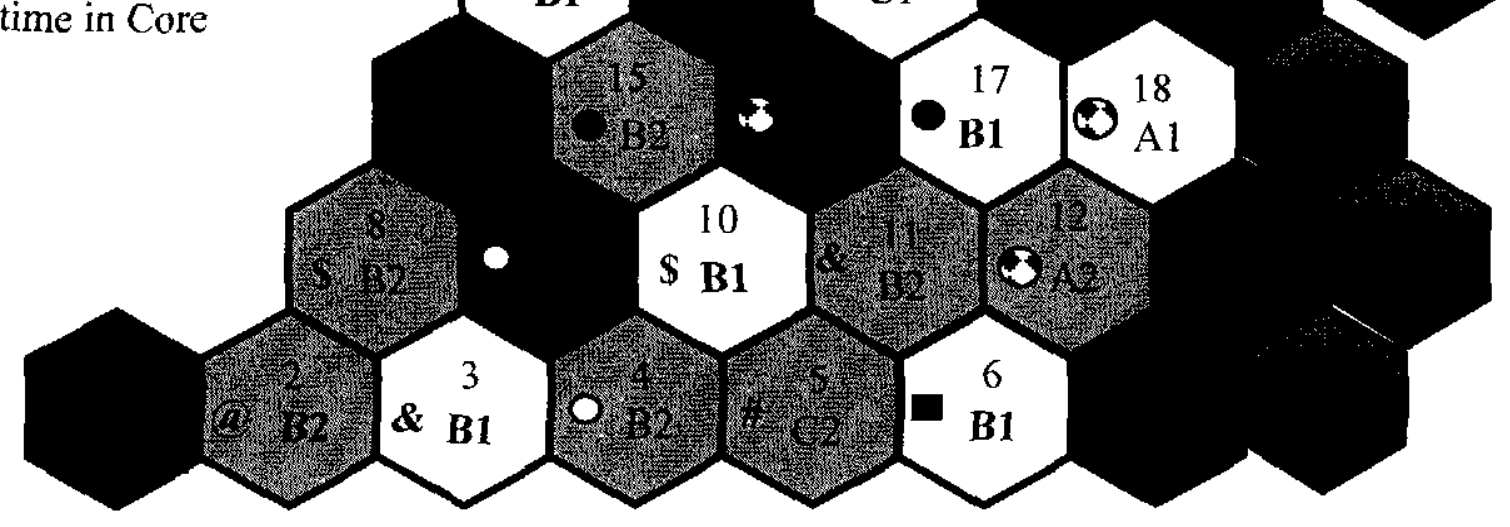

1st year assembly

2nd year assembly

$3 \mathrm{~d}$ year assembly

4th year assembly

RRC KI. Design Studies of “100\% Pu” Type MOX Lead Test Assembly (Report for FY99) 
Figure A.2. Model of VVER-1000 Radial Reflector

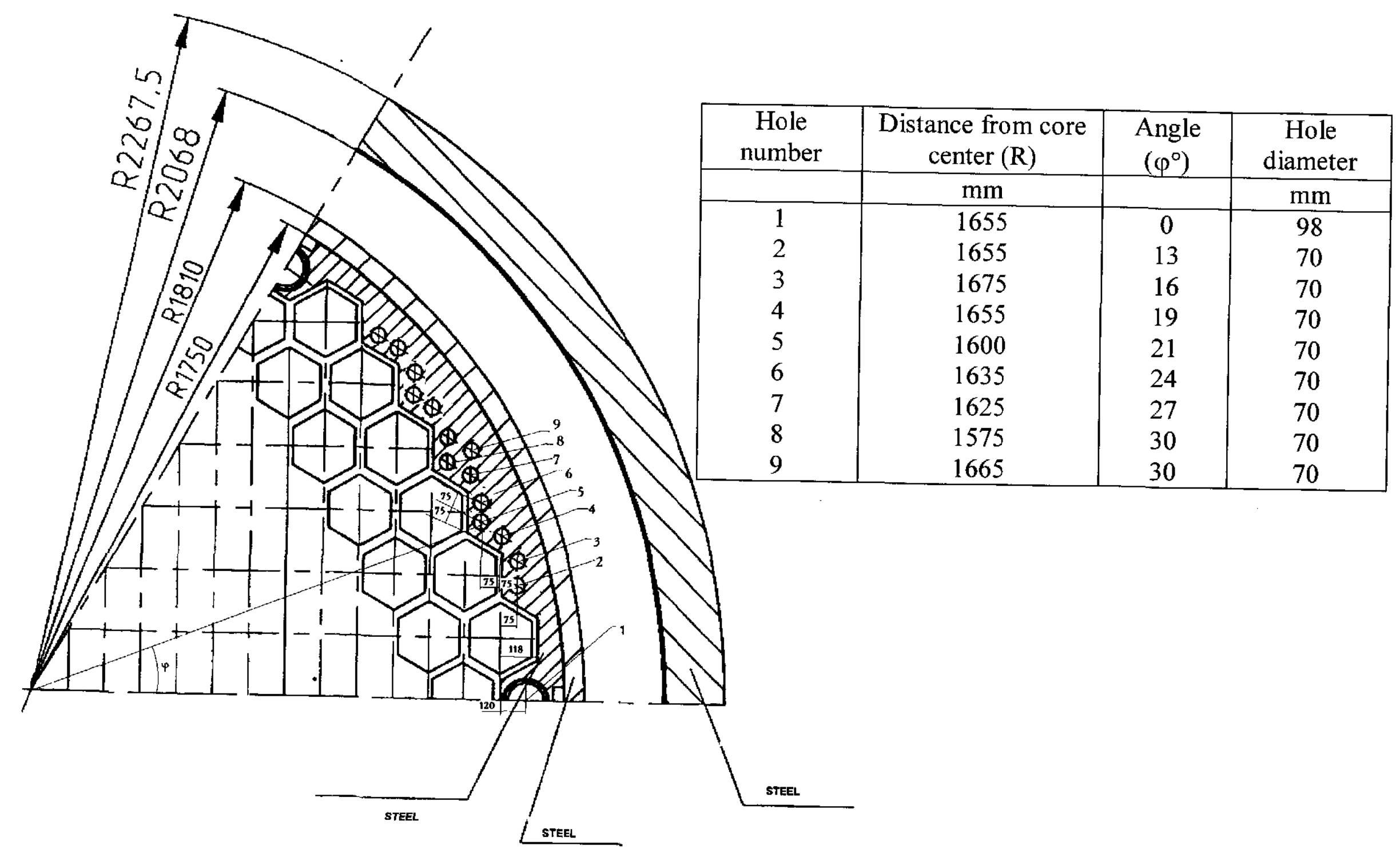

RRC KI. Design Studies of “100\% Pu” Type MOX Lead Test Assembly (Report for FY99) 
Fig.A.3. Reflector "assembly" of type 1

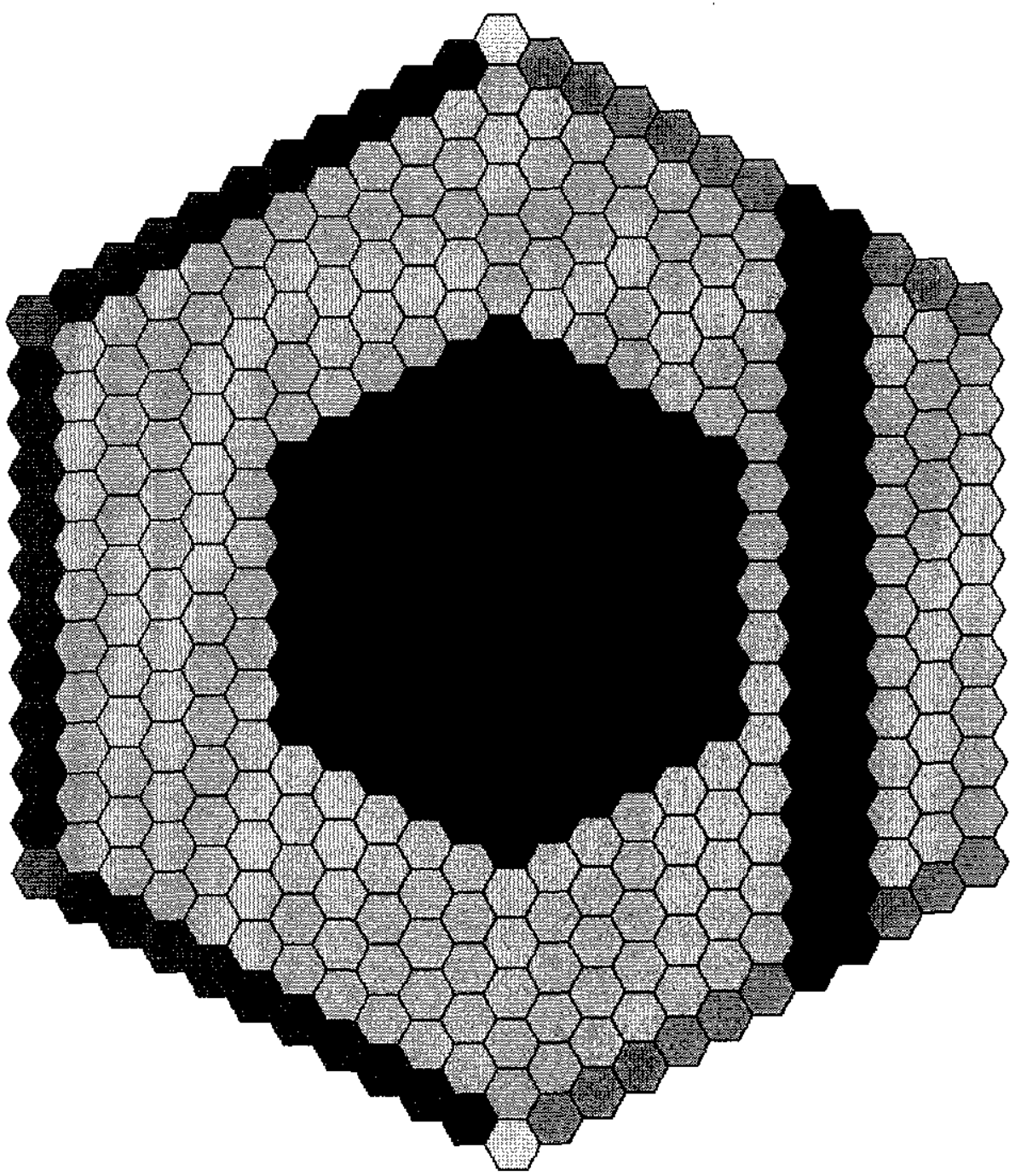

Steel 100 Water 0
Steel 0 Water 100
Steel 11 Water 89
Steel 26 Water 74


Fig.A.4. Reflector "assembly" of type 2
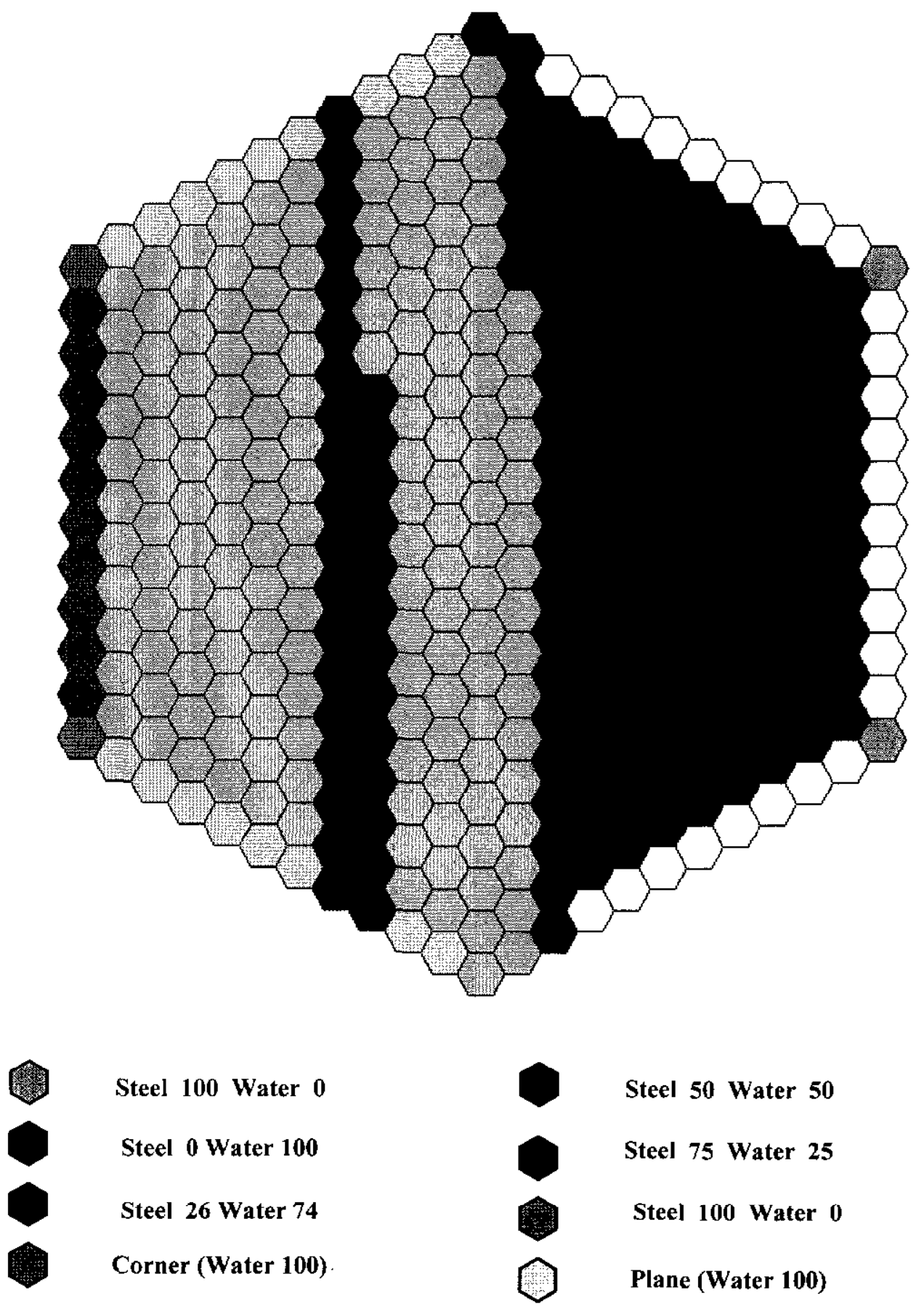
Fig.A.5. Reflector "assemb/y" of type 3
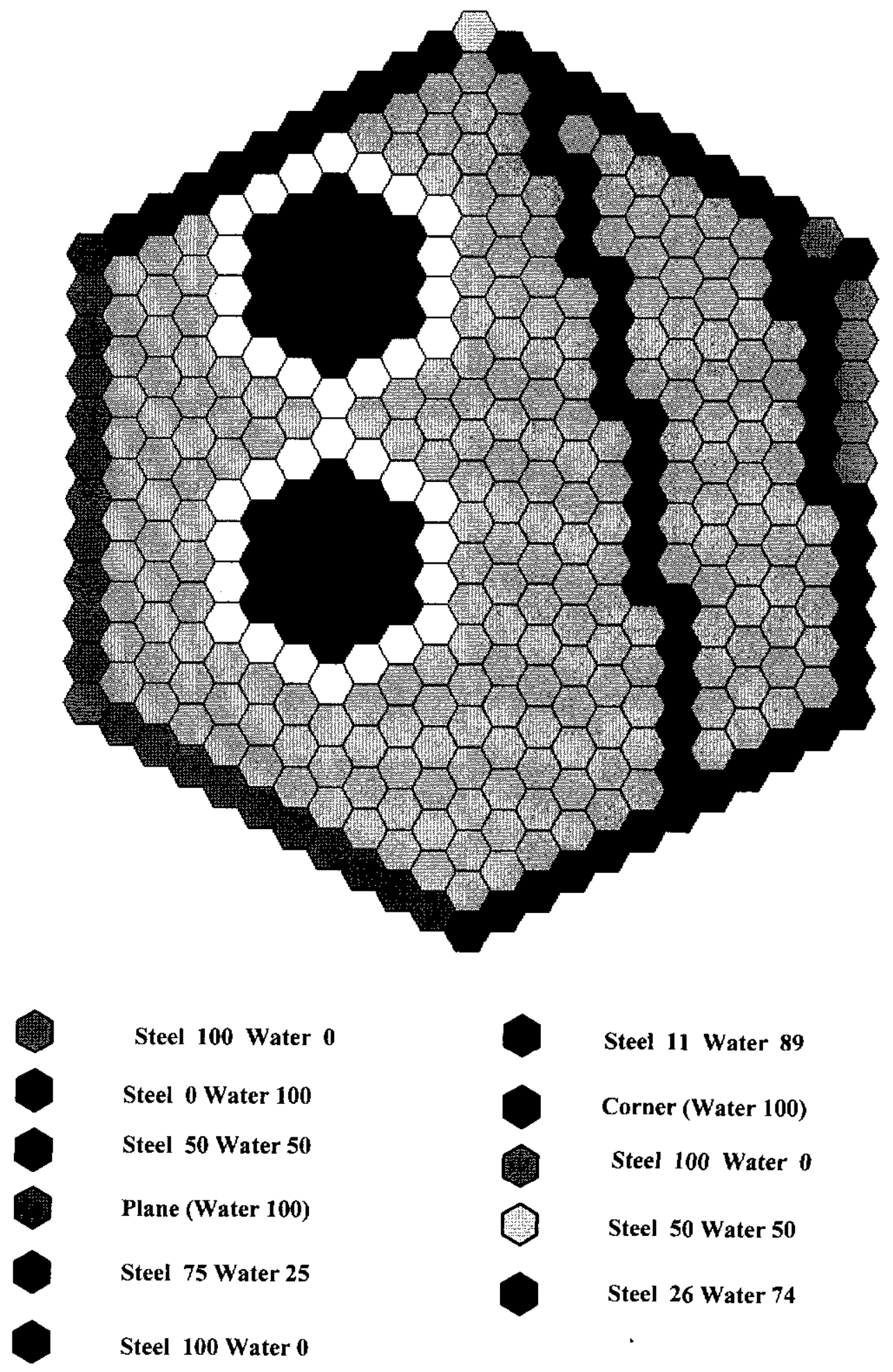

Steel 11 Water 89

Corner (Water 100)

Steel 100 Water 0

Steel 50 Water 50

Steel 26 Water 74 
Fig.A.6. Reflector "assembly" of type 4

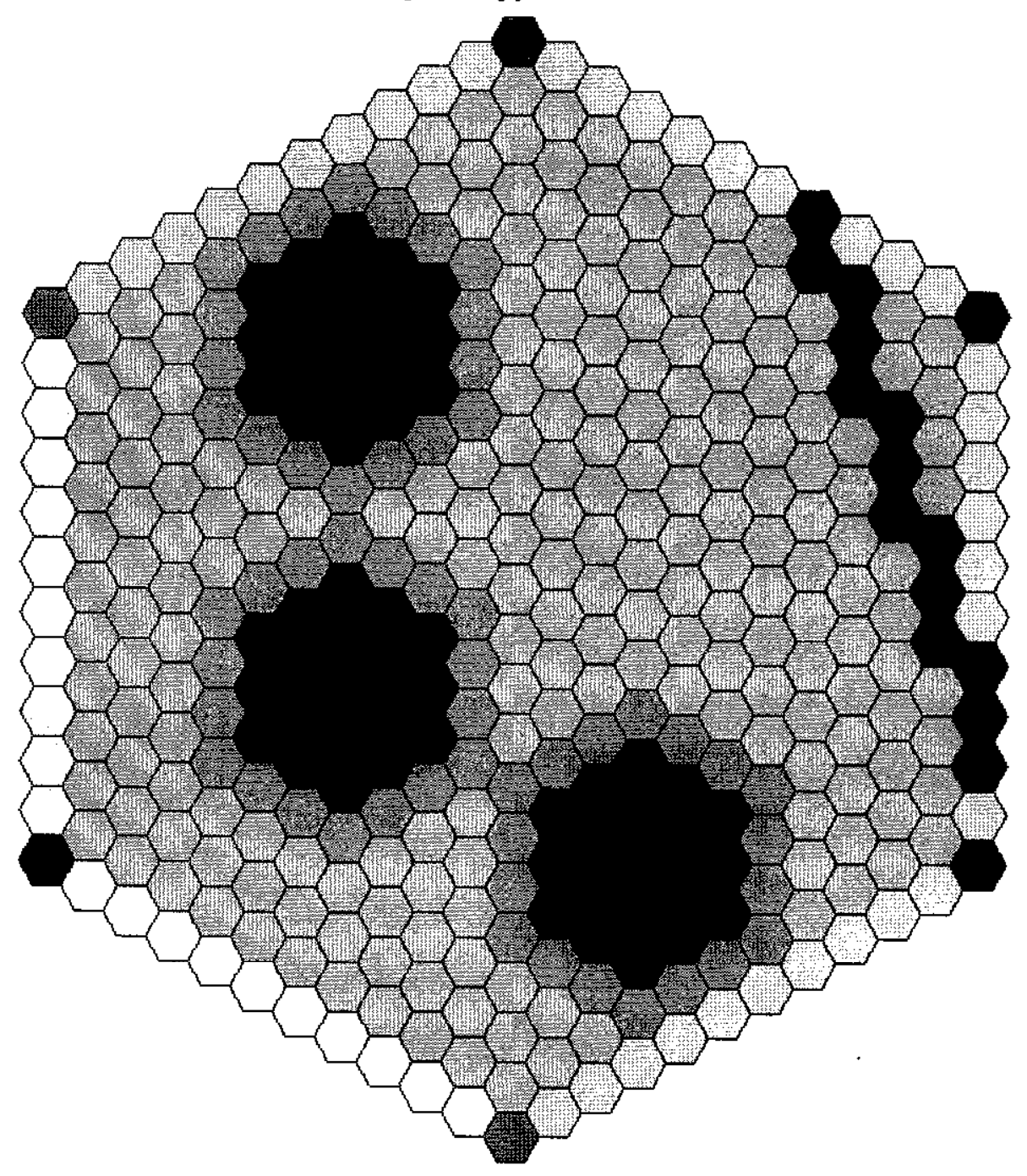

Steel 100 Water 0

Steel 0 Water 100

Steel 100

Steel 50 Water 50

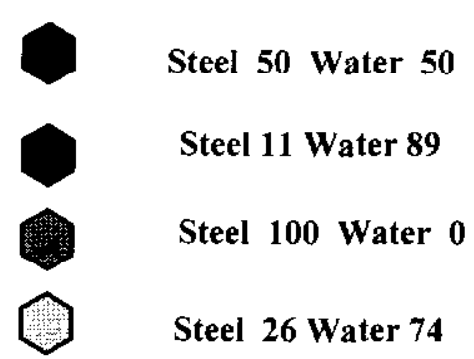


Fig.A.7. Reflector "assembly" of type 5

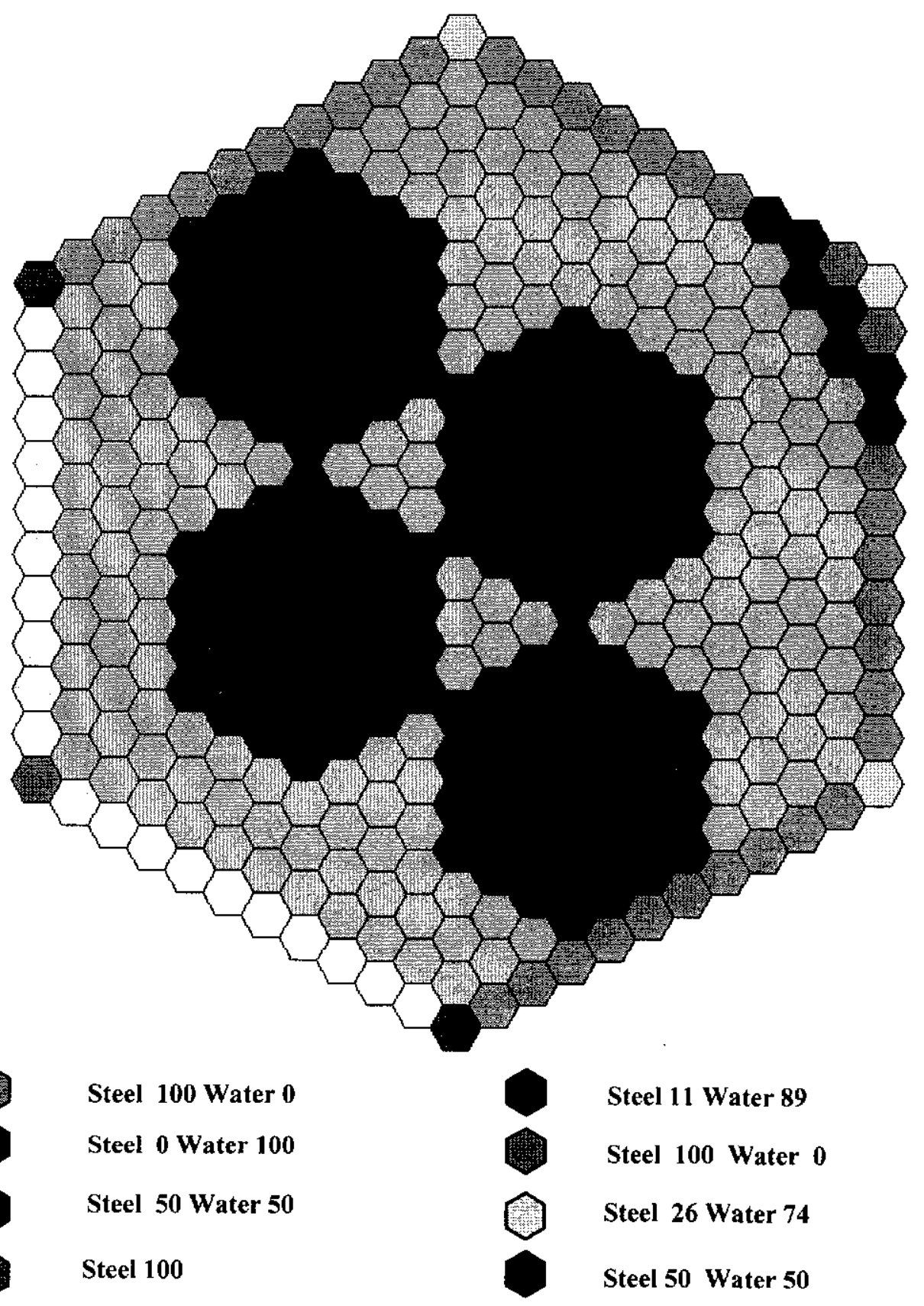




\section{INTERNAL DISTRIBUTION}

1. R. J. Belles

2-5. B. B. Bevard

6. M. D. DeHart

7. F. C. Difilippo

8. M. E. Dunn

9. R. J. Ellis

10. J. C. Gehin

11. S. R. Greene

12. R. F. Holdaway

13. D. Hollenbach

14. D. T. Ingersoll
15. S. B. Ludwig

16. M. A. Kuliasha

17. G. E. Michaels

18-19. R. T. Primm, III

20. C. C. Southmayd

21. D. L. Williams, Jr.

22. G. L. Yoder, Jr.

23. Central Research Library

24-25. ORNL Laboratory Records (OSTI)

26. ORNL Laboratory Records-RC

\section{EXTERNAL DISTRIBUTION}

27. M. L. Adams, Department of Nuclear Engineering, Texas A\&M University, Zachry 129, 3133 TAMU, College Station, TX 77843

28. H. Akkurt, 2919 Cooley Building, 2355 Bonisteel Boulevard, Ann Arbor, MI, 48109-2104

29. D. Alberstein, Office of Fissile Materials Disposition, U. S. Department of Energy, NN-63, 1000 Independence Avenue SW, Washington DC 20585

30. Dr. Kiyonori Aratani; Surplus Weapons Plutonium Disposition Group; International Cooperation and Nuclear Material Control Division; Japan Nuclear Cycle Development Institute; 4-49 Muramatsu, Tokai-mura, Naka-gun, Ibaraki-ken, Japan

31. John Baker, Office of Fissile Materials Disposition, U. S. Department of Energy, NN-63, 1000 Independence Avenue SW, Washington DC 20585

32. J. B. Briggs, Idaho National Environmental and Engineering Laboratory, P.O. Box 1625-3855, Idaho Falls, ID 83415-3855

33. M. S. Chatterton, Office of Nuclear Reactor Regulation, MS O10B3, United States Nuclear Regulatory Commission, Washington, D.C. 20555-0001

34. K. Chidester, Los Alamos National Laboratory, MS-E530, NMT 15, P.O. Box 1663, Los Alamos, NM 87545

35. Mr. Richard H. Clark, Duke Cogema Stone \& Webster, 400 South Tryon Street, WC-32G, P. O. Box 1004, Charlotte, NC 28202

36. W. Danker, U. S. Department of Energy, NN-62, 1000 Independence Avenue SW, Washington DC 20585

37. Dr. Alexandre Ermolaev; Balakovo Nuclear Power Plant, Saratov Region, Balakovo-26, Russia, 413866

38. T. Gould, Lawrence Livermore National Laboratory, P.O. Box 808, MS-L186, Livermore, CA 94551

39. L. Jardine, Lawrence Livermore National Laboratory, P.O. Box 808, MS-L166, Livermore, CA 94551 
40. Dr. Alexander Kalashnikov, Institute of Physics and Power Engineering, 1 Bondarenko Square, Obninsk, Kaluga Region, Russia 249020

41. Richard W. Lee, Office of Nuclear Reactor Regulation, MS O10B3, United States Nuclear Regulatory Commission, Washington, D.C. 20555-0001

42. Mr. Steve Nesbit, Duke Cogema Stone \& Webster, 400 South Tryon Street, WC32G, P. O. Box 1004, Charlotte, NC 28202

43. Nagao Ogawa; Director and General Manager; Plant Engineering Department; Nuclear Power Engineering Corporation; Shuwa-Kamiyacho Building, 2F; 3-13, 4-Chome Toranomon; Minato-Ku, Tokyo 105-0001, Japan

44-48. Dr. Alexander Pavlovitchev, Russian Research Center "Kurchatov Institute," Institute of Nuclear Reactors, VVER Division, VVER Physics Department, 123182, Kurchatov Square, 1, Moscow, Russia

49. K. L. Peddicord, Associate Vice Chancellor, Texas A\&M University, 120 Zachry, College Station, TX 77843-3133

50. U. Shoop, Office of Nuclear Reactor Regulation, MS O10B3, United States Nuclear Regulatory Commission, Washington, D.C. 20555-0001

51. J. Thompson, Office of Fissile Materials Disposition, U.S. Department of Energy, NN-61, 1000 Independence Avenue SW, Washington, DC 20585

52. Fitz Trumble, Westinghouse Savannah River Company, Building 730R, Room 3402, WSRC, Aiken, SC 29808

53. Boris E. Volkov; Head of Division; EDO Gidropress; 21 Ordzhonikidze Street; Podolsk, Moscow district, Russia 142103 